\author{
UNIVERSIDADE DE SÃo PAULO \\ Faculdade de Filosofia, Letras e CiênCias Humanas \\ DEPARTAMENTO DE HistóRIA \\ Programa de Pós-graduação em História Social
}

DAVID WILliam APARECIDO RIBEIRO

\title{
CARTOGRAFIA DAS RELAÇÕES \\ As condições da produção intelectual e os percursos da escrita histórica de Jaime Cortesão no Brasil (1940-1957)
}

Dissertação apresentada ao Programa de PósGraduação em História Social, do Departamento de História da Faculdade de Filosofia, Letras e Ciências Humanas da Universidade de São Paulo para a obtenção do título de Mestre.

Área de concentração: História Social

Orientação: Prof. ${ }^{a}$ Dr. ${ }^{a}$ Maria Cristina Cortez Wissenbach

Versão corrigida

São PaUlo 
Autorizo a reprodução e divulgação total ou parcial deste trabalho, por qualquer meio convencional ou eletrônico, para fins de estudo e pesquisa, desde que citada a fonte.

Catalogação na Publicação

Serviço de Biblioteca e Documentação

Faculdade de Filosofia, Letras e Ciências Humanas da Universidade de São Paulo

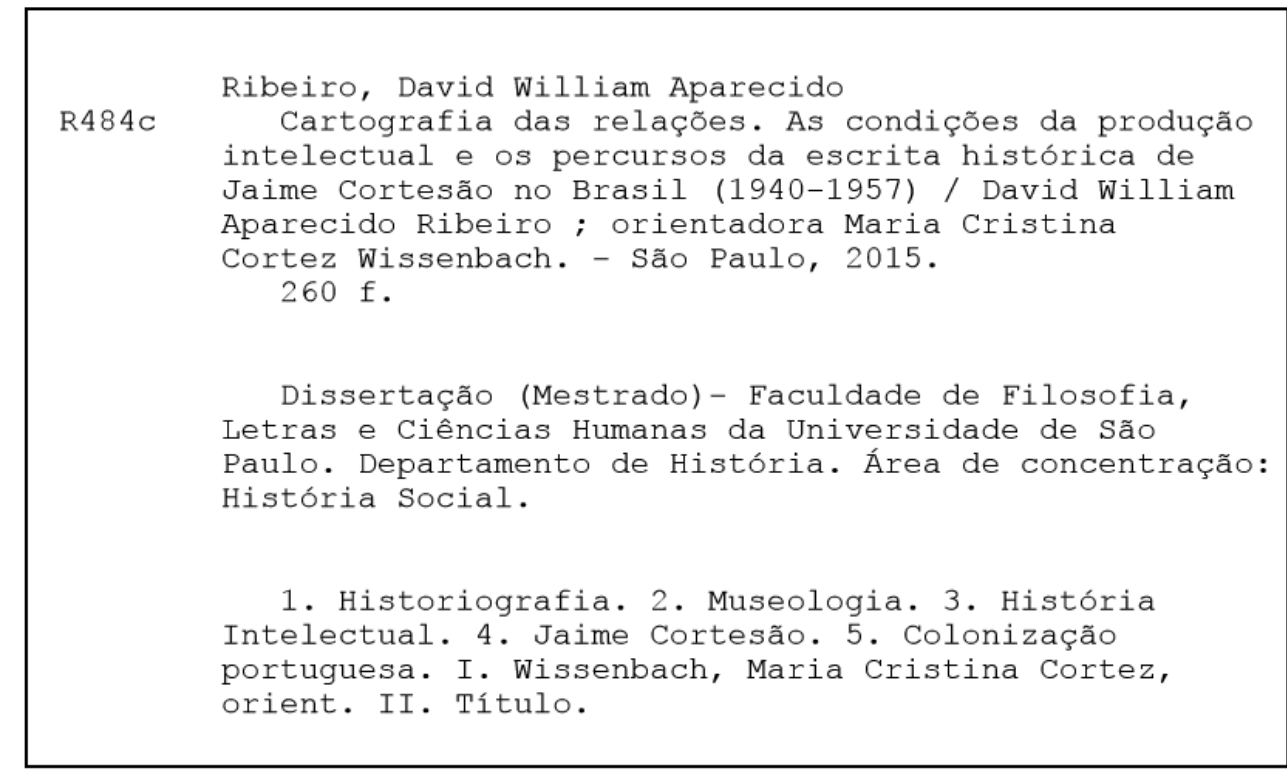


À memória de Maria Tristão Silveira (1919-2012) Mulher de história admirável Minha avó 


\section{Agradecimentos}

Aguyjevete!

Profunda gratidão...

Muitas e muitos tornaram possível o percurso que é apresentado neste trabalho. Das mais diversas formas, são pessoas, lugares e vivências que deram o estímulo ao caminhar, ao olhar, ao sentir, ao pensar e dar sentido a um processo tantas vezes difícil. Inicialmente, agradeço à minha orientadora, a professora Maria Cristina Cortez Wissenbach. Muito mais do que bibliografias e indicações seguras e instigantes de percurso, sua orientação me fez trabalhar com o olhar, a mente, a sensibilidade, que só uma historiadora tão profundamente consciente de seu papel nesse mundo poderia proporcionar.

Aos professores Miguel Soares Palmeira e Íris Kantor, agradeço imensamente pelas leituras e contribuições decisivas que deram desde o início do meu caminho de pós-graduando, e que na banca de qualificação avaliaram e deram orientações que busquei seguir. Agradeço também aos professores e professoras que decisivamente me instigaram a pensar nessas reflexões que agora apresento e em tantas outras: Heloísa Barbuy, Leila Leite Hernandez, Jaime Oliva, Teresa da Cruz e Silva, Paulo César Garcez Marins, Lúcia Helena Oliveira Silva, Patricia Hansen, Antonio Celso Ferreira, Tania Regina de Luca, Zélia Lopes da Silva, Lidiane Soares Rodrigues, Angela Maria de Castro Gomes, Dulce Pandolfi, Francisco Palomanes Martinho, Claudia Castelo, Ana Nemi.

À Cátedra Jaime Cortesão/Instituto Camões, pela bolsa concedida para que eu pesquisasse no arquivo de Cortesão em Lisboa no ano de 2014, agradeço, como também o faço à professora Vera Ferlini. Da mesma forma, sou imensamente grato às funcionárias do serviço de Reservados da Biblioteca Nacional de Portugal, em nome da Dr. ${ }^{a}$ Fátima Lopes.

No curto período de dois meses em Portugal, a Prefeitura do Município de São Paulo não somente me permitiu o afastamento das atividades como professor da rede pública como, de alguma forma, igualmente financiou essa pesquisa. Grato por ser parte desta rede.

Ao grupo de orientandos (e companheiros de muitas horas) da professora Cristina Wissenbach, agradeço a Juliana Paiva - uma das primeiras leitoras do 
trabalho -, Ivana Pansera, Rafael Galante, Elis Queiroz, Elaine Ribeiro, Yara Morena, Márcia Pacito, Rosana Gonçalves, Gilson Brandão, Pedro Cunha: na certeza de que parcerias como essas são fundamentais para trabalhos e lutas que vão muito além da academia. Junto a esses, agradeço à experiência transformadora vivida nos quilombos de Ivaporunduva, Pedro Cubas e Mandira.

Aos amigos e colegas de trabalho de hoje e de sempre, parcerias dos tempos da graduação na UNESP/Assis, do Museu Afro Brasil, das escolas da rede pública municipal de São Paulo, da USP e de tantos outros espaços, sou profundamente grato por tantas trocas, aprendizados, vivências. A Anelize Vergara, Camila Bueno, Mateus Gaiotto e Talita Molina, pessoas com as quais os laços de amizade também estão unidos às questões de pesquisa, agradeço pelas intensas trocas presentes e futuras. A Fernando Vian, Adams Alves, Paulo Santos, sou grato pela relação de família que construímos. Dos "de Assis", agradeço também a Mariana Boscariol (também "de Lisboa"), Stefânia Santos, Denise Lopes, Diego Semede, Victor Cruz. A Renata Cintra e a Maurício Reis - que nos deixou tão repentinamente - deixo aqui registrada a homenagem da intensa e marcante amizade e o desejo de levar adiante pelo menos alguns de seus (nossos) projetos.

Do trabalho no Museu Afro Brasil, ressalto a experiência da educação como mediação, experiência que formou grande parte das bases deste texto, junto das também fundamentais amizades e parcerias de Joyce Rodrigues, Glaucea Helena, Cíntia Ribeiro da Rocha, Claudio Rubiño, Felipe Torres, Luana Minari, Juliana Serzedello, Thiago Sapede, Daniela Ortega, Dulci Lima, André Santos, Janaina Barros, Giselda Pereira, Solange Ardila, Bruno Mamede, Sandra Salles, Renata Felinto. Viva a Nação!

Aos colegas da pós-graduação e do cotidiano na Universidade de São Paulo, agradeço especialmente a Franco Della Valle, Eduardo Peruzzo, Milena Natividade, Tathianni Silva. Com vocês compartilhei temas de pesquisa, perspectivas de análise, visões de mundo.

Do cotidiano escolar, não poderia deixar de lembrar aqueles e aquelas com os quais busco os sentidos educação: Cleide de la Torre, Mônica Vilela, Teresinha Kersch, Flávia Silva, Adriana Vasconcellos, Luiz Fernando, Viviane Carenzi, Wellington Pereira, Cadu Fernandes, Waleska Carvalheiro, Eudeni Dias, Sandra Romeu, Silvia Fernandes, Renata Pardim, Adriana Watanabe. A vocês e a todos os incríveis alunos que tenho, agradeço pela convivência. 
Às minhas famílias, por fim, não somente agradeço como também dedico este trabalho.

Aos meus pais, Jessé Ribeiro e Marisa Silveira, agradeço o investimento que fizeram em mim, o apoio, o amor e o orgulho que sinto na expressão de vocês quando olho para aquela foto da minha formatura. Sabemos o quanto a nossa vida, como a de muitos brasileiros, enfrenta desafios e injustiças. Sabemos o quanto a educação é um instrumento para transformar isso. À minha irmã, alfabetizadora e segunda mãe, Vete Miranda, agradeço pela presença constante e pelo estímulo certo. Que a nossa linda Heloísa possa viver e construir um mundo bem melhor, ao seu lado, ao lado do Marcelo e por onde quer que ela caminhe! Agradeço também ao meu mano Josué Miranda, pessoa de grande coração, e à minha querida cunhada Cláudia de Nadai. A meu primo Luiz Carlos Alves e à minha tia Benedita Silveira Alves, agradeço pelo constante apoio desde sempre nessa caminhada toda. À minha avó, Dirce Abud, e aos já falecidos, Maria Silveira e Frahim Abud, agradeço por todas as histórias que ouvi e que me formaram. A partir de vocês, fortaleço o meu vínculo com os meus ancestrais. À família que a vida dá, também agradeço imensamente, em especial à minha "mãe número 3" Eliane Baroni, à minha cunhada Milena Baroni e à (também minha) avó Yeda Maria Azambuja Silveira.

Há, ainda, a família que constituí. Família que, por enquanto, só é formada por nós dois. Essa família foi e é fundamental nesse e em todos os projetos, dos quais participa ativamente, de todos os passos. Companheiro na vida cotidiana, companheiro na vida acadêmica, companheiro de inquietações, companheiro na busca pelos sentidos das coisas. Companheiro no sentido pleno da palavra, é você, Lorenzo Baroni Fontana, o coautor deste trabalho: ao sermos família, somos um. 
Se oriente, rapaz

Pela constelação do Cruzeiro do Sul

Se oriente, rapaz

Pela constatação de que a aranha

Vive do que tece

Vê se não se esquece

Pela simples razão de que tudo merece

Consideração

Gilberto Gil. "Oriente”. Expresso 2222, 1972. 
RIBEIRO, David W. A. Cartografia das relações: as condições da produção intelectual e os percursos da escrita histórica de Jaime Cortesão no Brasil (19401957). 2015. 260 p. Dissertação (Mestrado em História Social) - Faculdade de Filosofia, Letras e Ciências Humanas, Universidade de São Paulo, São Paulo, 2015.

\section{Resumo}

Jaime Cortesão (1884-1960) viveu no Brasil entre 1940 e 1957 e durante esse período constituiu grande parte de sua obra historiográfica. Emigrado de Portugal por pressão do salazarismo, desfrutou de condições bastante privilegiadas à sua produção intelectual, favorecidas tanto pelas instituições governamentais nas quais trabalhou quanto pelas relações que cultivou.

A análise das condições de sua produção intelectual no Brasil permite iluminar questões da política cultural e da produção do conhecimento no contexto da Era Vargas. Considerando que identidade nacional, modernidade, interiorização do país eram alguns dos temas que mobilizavam a intelligentsia nacional, busco neste trabalho identificar as conexões entre os trabalhos de Cortesão e o intenso debate promovido dentro e fora do aparelho do Estado brasileiro. Neste aspecto, a sua atuação na Biblioteca Nacional e no Ministério das Relações Exteriores, ampliada por uma intensa colaboração na imprensa paulistana e carioca, suscita reflexões acerca dos percursos de sua escrita da história da colonização portuguesa. Do ponto de vista do autor, a ação colonizadora é protagonizada pelos bandeirantes e é criadora de uma "família luso-tupi", de relações simbióticas entre colonos e nativos a partir do planalto paulista.

Essas concepções, que se encontraram também na exposição histórica em comemoração ao quarto centenário da fundação da cidade de São Paulo (1954), organizada por Cortesão no conjunto de um amplo evento, local e nacionalmente significativo, permitiam a Portugal manter-se presente na identidade brasileira, bem como participar com relevo da celebração do ingresso do Brasil na modernidade.

Palavras-chave: Jaime Cortesão; história intelectual; historiografia; museologia; colonização portuguesa. 
RIBEIRO, David W. A. Cartography of relationships: the conditions of intellectual production and paths of Jaime Cortesão's historical writing in Brazil (1940-1957). 260 p. Dissertation (Masters in Social History), 2015. Faculdade de Filosofia, Letras e Ciências Humanas, Universidade de São Paulo, São Paulo, 2015.

\section{Abstract}

Jaime Cortesão (1884-1960) lived in Brazil between 1940 and 1957 and during this period constituted most part of his historiographical work. Emigrated from Portugal by Salazar pressure, he has enjoyed quite privileged conditions to his intellectual production; both government institutions in which he worked as well as the relationships he has cultivated favored those conditions.

The analysis of the conditions of his intellectual production in Brazil allows illuminate issues of cultural policy and production of knowledge in the context of Vargas government. Taking into consideration that national identity, modernity, the country internalization were some of the issues which mobilized the national intelligence, I aim in this paper identify the connections between Cortesão works and the intense debate promoted within and outside the Brazilian state apparatus. In this respect, his performance at the National Library and the Ministry of Foreign Affairs, magnified by intense collaboration in São Paulo and Rio de Janeiro press, raises reflections on the paths of his writing about the history of Portuguese colonization. From the author's point of view, the colonizing action is led by pioneers and is the creator of a "Portuguese-Tupi family" of symbiotic relationships between settlers and natives from the Sao Paulo plateau

These concepts, which are also found in the historical exhibition commemorating the fourth centenary of the founding of the city of São Paulo (1954), organized by Cortesão in the set of a large event, locally and nationally significant, allowed Portugal to keep present inside the Brazilian identity and participate considerably of the celebration of Brazil's entry into modernity.

Keywords: Jaime Cortesão; intellectual history; historiography; Portuguese colonization; museology. 
RIBEIRO, David W. A. Une cartographie des relations : les conditions de la production intellectuelle et les parcours de 1'écriture historique de Jaime Cortesão au Brésil (1940-1957). 260 p. Mémoire (Master en Histoire Sociale), 2015. Faculdade de Filosofia, Letras e Ciências Humanas, Universidade de São Paulo, São Paulo, 2015.

\section{Résumé}

Entre 1940 et 1957, Jaime Cortesão (1884-1960) a élu domicile au Brésil, pays où il a construit une grande partie de son travail historiographique. Contraint à quitter le Portugal en raison du régime salazariste, il s'est installé au Brésil, où il a pu jouir de conditions assez favorables au déploiement de sa production intellectuelle. Ces conditions étaient favorisées par les institutions gouvernementales dans lesquelles il a travaillé comme par les relations interpersonnelles qu'il a cultivées.

L'analyse des conditions de sa production intellectuelle au Brésil permet d'élucider quelques questions de la politique culturelle et de la production de savoirs dans le cadre de l'Ère Vargas. Compte tenu du fait que certains thèmes tels que l'identité nationale, la modernité et l'intériorisation du pays mobilisaient l'intelligentsia nationale de l'époque, je chercherai ici à identifier les rapports entre le travail de Cortesão et le vif débat mis en avant au sein et en dehors de l'appareil de l'État brésilien. À cet égard, son rôle dans la Bibliothèque Nationale aussi bien que dans le ministère des Affaires étrangères, renforcé par une intense participation dans la presse des villes de São Paulo et de Rio de Janeiro, suscite des réflexions sur les parcours de son écriture de l'histoire de la colonisation portugaise. Du point de vue de l'auteur, l'action colonisatrice est effectuée par les bandeirantes et elle crée une « famille luso-tupi ", des relations symbiotiques entre les colons et les autochtones à partir du plateau pauliste.

Ces conceptions ont également pu être identifiées dans l'exposition historique célébrant le quatrième centenaire de la fondation de la ville de São Paulo (1954), organisée par Cortesão dans le cadre d'un événement d'envergure, localement et nationalement significatif. Elles permettaient au Portugal de garder une présence active dans l'identité brésilienne et de participer à la célébration de l'entrée du Brésil dans la modernité.

Mots clés : Jaime Cortesão ; histoire intellectuelle ; historiographie ; colonisation portugaise ; muséologie. 


\section{ÍNDICE DE IMAGENS}

Imagem 1. Chegada de material para a Exposição de História .

Imagem 2. Anúncio da Exposição de História de São Paulo no quadro da História do Brasil

Imagem 3. Um desfile inédito da História de São Paulo, no quadro da História do Brasil!

Imagem 4. I Feira Internacional de São Paulo

Imagem 5. Folha de rosto do Guia para o Visitante. Exposição de História de São Paulo no quadro da História do Brasil

Imagem 6. Aspecto da Seção I - O Descobrimento dos Litorais .......................................133

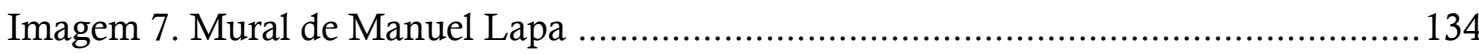

Imagem 8. Aspecto da Exposição. Partes da Seção I vistas de cima. ................................ 135

Imagem 9. A Adoração dos Reis Magos. Retábulo da Sé de Viseu. Vasco Fernandes (Grão Vasco), óleo sobre madeira, c. 1506

Imagem 10. A cultura do índio, que abre a II seção da Exposição de História .................140

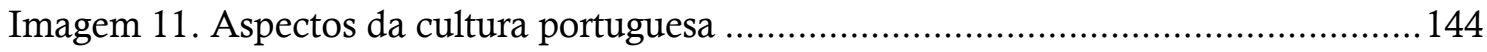

Imagem 12. O povo português do século de Quinhentos nas fainas pastoris e agrícolas. . 145 Imagem 13. Missa de 25 de janeiro (Conversão de São Paulo) de 1554. Painel de Manuel Lapa.

Imagem 14. Baixos-relevos da escultora Irene de Vasconcelos no painel "A criação da Vila"

Imagem 15. IV Seção: painel de Bernardo Marques sobre a origem da palavra e do organismo bandeira

Imagem 16. IV Seção. Mapa das vias (indígenas) de difusão cultural 160 Imagem 17. Painel de Clóvis Graciano representando a mineração em um rio de montanha. 168

Imagem 18. Parte do mural de Tarsila do Amaral. 171

Imagem 19. Seção VI. Busto de Alexandre de Gusmão e painel sobre assinatura do Tratado de Madri (1750) 175

Imagem 20. Seção VI. Painel de Artur Jorge sobre a "Expedição Filosófica" de Alexandre Rodrigues Ferreira 178

Imagem 21. Detalhe da VIII Seção - São Paulo no Império. Ao fundo, painel de Di Cavalcanti sobre a lavoura cafeeira 186

Imagem 22. Painel de Di Cavalcanti sobre a lavoura cafeeira 186

Imagem 23. Monumento às Bandeiras tingido de tinta vermelha 246 


\section{ÍNDICE DE ABREVIATURAS}

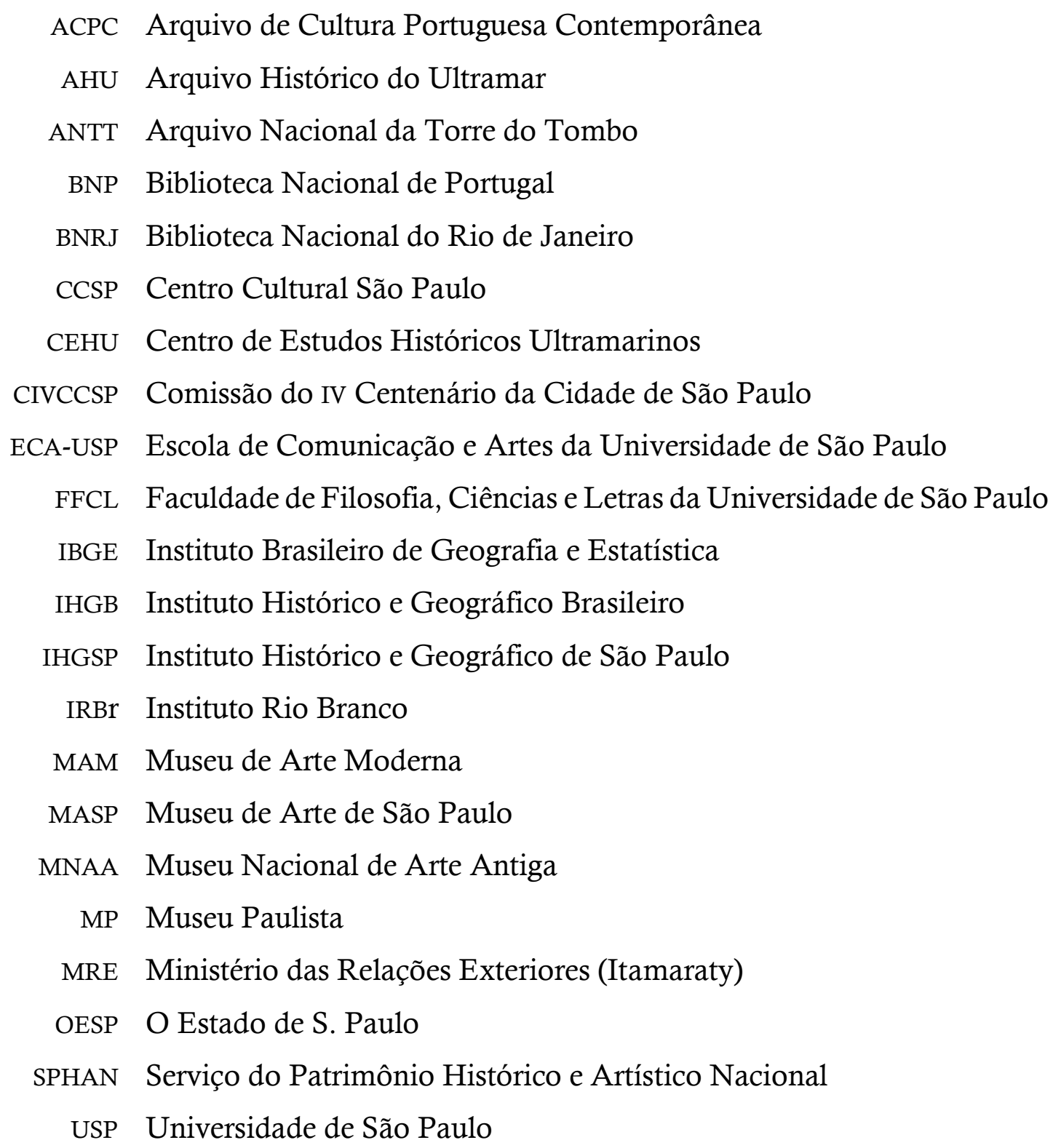




\section{Sumário}

INTRODUÇ̃̃O

CAPÍtulo 1. Cortesão e o Brasil: exílio, sociabilidades e condições da produção intelectual

De Lisboa ao Rio, a bordo do S/S Angola, 1940: o passageiro e a bagagem. 33

Sensibilidades, sociabilidades e condições de produção e disseminação

Cortesão e os debates brasileiros: construindo um espaço, cartografando relações....... 53

Um historiador luso-brasileiro

CAPÍtulo 2. Percursos da escrita histórica: a narrativa da conquista do sertão,

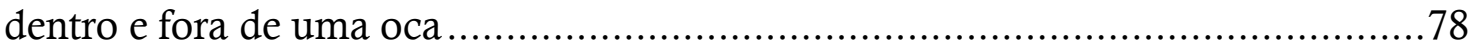

Cortesão, o sertão e os caminhos da construção de uma nação...................................... 78

São Paulo, capital cultural: a cidade às vésperas de seu Quarto Centenário .................. 91

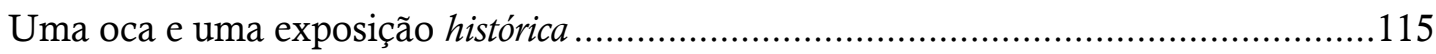

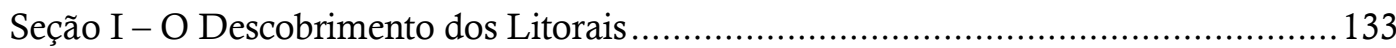

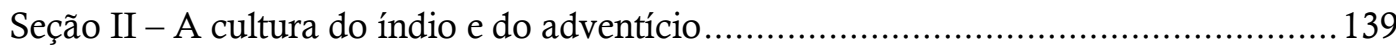

Seção III - A fundação de São Paulo e o pré-bandeirismo ........................................... 146

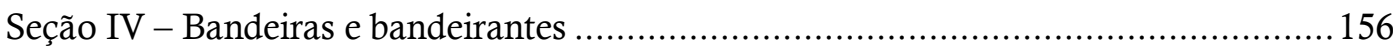

Seção V - A Capitania de São Paulo e a Expansão Mineradora .................................... 164

Seção VI - São Paulo e a formação dos limites do Brasil ............................................ 171

Seção VII - São Paulo e a Independência do Brasil ..................................................... 179

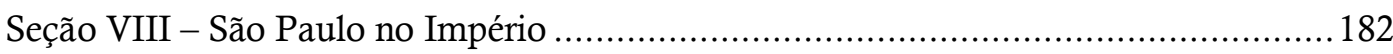

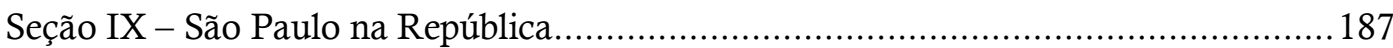

Didática, cívica, científica - e inédita: a Exposição de História de São Paulo no quadro da produção do conhecimento

CAPÍTULO 3. Uma historiografia das relações: especificidades da colonização portuguesa, poder e produção do conhecimento

Índios, bandeirantes e uma família luso-tupi no planalto paulista

Uma historiografia das relações: amorabilidade franciscana, luso-tropicalismo e as peculiaridades de uma colonização portuguesa .

História, mediações culturais e lusofonias

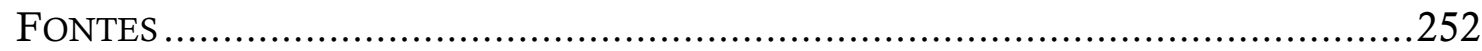

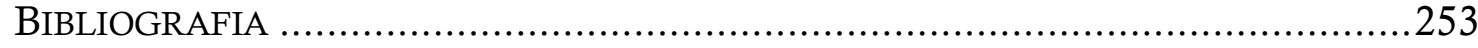




\section{INTRODUÇÃO}

O intelectual português Jaime Cortesão, nascido nas cercanias de Coimbra no ano de 1884, teve uma trajetória que é considerada como a de "um dos grandes de Portugal", nas palavras de um de seus biógrafos. ${ }^{1}$ Médico, poeta, dramaturgo, desenhista, republicano, combatente da Primeira Guerra, historiador, cartólogo. ${ }^{2}$ Muitas foram as suas áreas de atuação, intimamente ligadas a um movimento amplo de orientação à República em seus primeiros passos. Instável, a República Portuguesa sofreu um golpe aos dezesseis anos, vivendo um governo autoritário até meados da década de 1970, entre as chamadas ditaduras Militar e Nacional e o Estado Novo, tendo Antônio de Oliveira Salazar como um de seus principais expoentes.

De diretor da Biblioteca Nacional de Portugal, cargo a ele confiado desde 1919 pelo então presidente Antônio José de Almeida, Cortesão se tornou um exilado, migrando para Espanha, para a França e outros cantos da Europa, isso após participar de grupos contrários ao regime inaugurado em maio de 1926. Além de dar continuidade às suas atividades políticas, Jaime Cortesão passou a se dedicar à pesquisa histórica, compondo a maior parte de seus textos históricos no período em que esteve fora de Portugal e em contato com arquivos e documentações, tal como na Biblioteca Nacional da França.

Nos anos em que viveu fora de seu país, mas ainda no continente europeu, a situação política europeia se degenerava, até um novo estado de guerra se impor e forçar a sua saída de Paris, ocupada pelo exército nazista em 1940. De retorno a Portugal, foi preso pela polícia do regime salazarista e obrigado a deixar o país. Escolhendo o Brasil como destino, aportou no Rio de Janeiro no final daquele ano com parte de sua família. O país também vivia uma experiência autoritária, governado por um mesmo presidente há dez anos e desde 1937 com um regime

\footnotetext{
${ }^{1}$ Alfredo Ribeiro dos Santos, da cidade do Porto, publicou em 1993 a biografia Jaime Cortesão: um dos grandes de Portugal, apresentado pelo então presidente português Mário Soares (1986-1996), que descreve a sua proximidade com as ideias e ações do grupo de Cortesão. A referência à obra encontrase na bibliografia.

${ }^{2}$ Ao longo do trabalho, utilizarei diferentes categorias para fazer referência a Jaime Cortesão. Embora não sejam sinônimas, expressam a multiplicidade da ação de um intelectual, compreendido como um agente social a exercer a sua influência a partir da mediação cultural, mobilizando história, arte, geografia, literatura, museologia para transmitir determinados saberes e valores.
} 
ditatorial homônimo ao português: o Estado Novo, instaurado por Getúlio Vargas em 1937.

Para além do quadro político do Brasil, um olhar para as sensibilidades e sociabilidades do autor, colocando em destaque e discutindo a experiência do exílio, revela a rede de relações estabelecidas com os patrícios já residentes no Rio de Janeiro e em alguns casos também exilados por causa da ditadura portuguesa. $\mathrm{Na}$ então Capital Federal, a presença de casas editoras especializadas em obras de Portugal denota a presença de um grupo organizado de portugueses. ${ }^{3}$ A presença desses conterrâneos foi profissionalmente fundamental, além de provavelmente consoladora. Na relação com brasileiros, especialmente os que lhe prestaram as primeiras acolhidas, é marcante a circulação de intelectuais e instituições entre os dois lados do Atlântico: se por um lado Pedro Calmon e Afrânio Peixoto, intelectuais brasileiros que circulavam em espaços portugueses foram fundamentais na recepção de Cortesão na capital, abrindo as portas para que realizasse as suas primeiras conferências, por outro a comunidade portuguesa o destinou ao cargo de secretário do Gabinete Português de Leitura.

Além das conferências na cidade em que se estabeleceu, inicialmente no bairro de São Cristóvão e tempos depois no Flamengo, marcou presença também na capital paulista, dando a sua primeira conferência em São Paulo na sede d'A Gazeta, jornal de Cásper Líbero. Seus textos nas imprensas carioca e paulistana apontam não apenas sociabilidades intelectuais como também demonstram sua circulação entre a base do regime de Vargas e a sua oposição: entre o carioca $A$ Manhã e o paulistano $O$ Estado de S. Paulo, que congregava também diversos exilados portugueses. Apesar disso, o período em que Cortesão esteve no Brasil não corresponde integralmente ao regime encerrado em 1945, embora Getúlio retorne para um mandato presidencial depois de ter sido eleito pela população em 1950. Do cargo sairia apenas com o seu trágico suicídio em agosto de 1954, dias depois de comparecer à inauguração do Parque Ibirapuera em São Paulo.

Jaime Cortesão trabalhou também em instituições do governo brasileiro, atividades sobre as quais se debruçaram Maria Beatriz Nizza da Silva (1984) e Francisco Roque de Oliveira (2010), a primeira se dedicando à sua passagem pela

\footnotetext{
${ }^{3}$ Trata-se das casas Ediçâes Dois Mundos e Livros de Portugal, que foram inclusive responsáveis pela coleção Clássicos e Contemporâneos, idealizada e dirigida por Cortesão (SANTOS, 1993, p. 230).
} 
Biblioteca Nacional do Rio de Janeiro e o segundo abordando suas funções junto ao Ministério das Relações Exteriores e ao Instituto Rio Branco. Nestes espaços o historiador se dedicou à cartografia e à diplomacia, assim como a documentações inéditas como os Manuscritos da Coleção De Angelis, que foram publicados ao longo da década de 1950. A documentação se refere a indígenas, bandeirantes e jesuítas espanhóis em zonas disputadas pelas duas coroas ibéricas na grande região da bacia do Prata. Desta forma, o historiador se especializava em áreas que eram estratégicas para política nacional e que iam ao encontro de diversas das intenções do Estado Novo, tanto na integração territorial do país quanto na proteção das fronteiras dos interesses estrangeiros. Os cursos oferecidos por Cortesão deram origem a algumas de suas obras, como a encomendada para assinalar os dois séculos da assinatura do Tratado de Madri - Alexandre de Gusmão e o Tratado de Madrid (1750) -, publicada sob o selo do Ministério das Relações Exteriores.

No contexto experimentado pelo intelectual português, os debates sobre a identidade nacional brasileira eram intensos, promovidos em grande parte pelas políticas culturais do Estado Novo e também por uma produção crescente no campo intelectual institucionalizado nas universidades. O movimento modernista em suas múltiplas correntes e expressões também estava em cena, em muitos casos próximo ao programa cultural estadonovista e ao Ministério da Educação e Saúde, em torno da figura proeminente de Gustavo Capanema, como poderemos ver. À parte isto, é notável a circulação de ideias e as narrativas da história do império português, das quais participam brasileiros e portugueses, além daqueles que falavam das então colônias/províncias ultramarinas de Portugal na África, em torno de temas como o colonialismo, a mestiçagem, o luso-tropicalismo.

Os posicionamentos de Cortesão nesses debates não são sempre identificáveis, embora seja notável uma defesa da ideia de herança portuguesa na formação cultural brasileira, vista como constantemente ameaçada pelo alinhamento do país com o modelo dos Estados Unidos, entrando no mérito do debate sobre a modernidade que esse modelo representava naquele momento. Nesse sentido, as tentativas de sempre aproximar a história do Brasil à de Portugal renderam-lhe diversas críticas, como teremos oportunidade de observar.

Naquela que pode ser considerada a primeira etapa da trajetória de Cortesão no Brasil, nota-se o processo de envolvimento e de reconhecimento, a ponto de não 
ser mais considerado por aqueles brasileiros que lhe eram próximos como um estrangeiro, talvez por se dedicar tanto à história local e por inserir-se totalmente nos debates que tinham lugar no país. Sob a chancela do Ministério das Relações Exteriores, também representado na pessoa do ministro Osvaldo Aranha, Cortesão desfrutava de um lugar privilegiado no Brasil.

O convite para organizar a exposição histórica comemorativa do quarto centenário da fundação da cidade de São Paulo, que seria celebrado em 1954, pode ser visto como o centro de uma segunda etapa de sua produção brasileira, na qual a história das bandeiras e dos bandeirantes ganham relevo. Nominada como Exposição de História de São Paulo no quadro da História do Brasil e dispondo de uma grande equipe, formada por historiadores, artistas plásticos, intelectuais de diversas áreas e um apoio financeiro vindo tanto da Comissão encarregada de organizar os festejos, dirigida pelo industrial e mecenas ítalo-brasileiro Francisco Matarazzo Sobrinho, quanto da comunidade portuguesa organizada em São Paulo e Rio de Janeiro, preocupada em garantir o sucesso da empreitada capitaneada por um dos seus. $\mathrm{Na}$ tarefa, Cortesão serviu-se do conhecimento sobre documentos e arquivos europeus e brasileiros relacionados à história do Brasil e em 1953 partiu à Europa a serviço da comissão. Ao lado de Agostinho da Silva (seu genro e conterrâneo) ${ }^{4}$, Ernani Silva Bruno, Hélio Damante, Mário Neme ${ }^{5}$ e outros, a exposição foi pensada e executada, apresentando em perspectiva as abordagens, teses e conceitos por ele trabalhados sobretudo desde que se radicou no Brasil. A exposição foi montada no edifício hoje chamado de Oca, parte do conjunto arquitetônico desenhado pelo arquiteto Oscar Niemeyer no interior daquele que era o principal palco do megaevento paulistano: o Parque Ibirapuera.

A exposição também rendeu frutos, como o livro A fundação de São Paulo, capital geográfica do Brasil (1955), que apresenta a síntese do olhar de Cortesão sobre o processo da fundação da vila no planalto, representando o marco inicial da

\footnotetext{
${ }^{4}$ Sobre os trabalhos de Agostinho da Silva no Brasil, bem como a respeito de sua atuação na Exposição de história de São Paulo, ver OliveIRA Júnior, G. B. Agostinho da Silva e o Centro de Estudos Afroorientais (CEAO): a primeira experiência institucional dos estudos africanos no Brasil. Dissertação (Mestrado em História Social). São Paulo, Universidade de São Paulo, 2010.

${ }^{5}$ Tanto Mário Neme quanto Ernani Silva Bruno dirigiram museus de São Paulo nos anos que se seguiram às comemorações. Uma abordagem sobre a museologia no Brasil após a década de $1950 \mathrm{e}$ a exposição dirigida por Cortesão fazem parte do trabalho de SILVA, T. C. Um intelectual caipira na cidade: a trajetória de Mário Neme e sua gestão no Museu Paulista. Tese (Doutorado em História Social). São Paulo, Universidade de São Paulo, 2014.
} 
expansão e da colonização portuguesa do sertão da América do Sul, assim como a busca pelo acesso ao Rio da Prata. O conceito, que era associado ao movimento dos bandeirantes e a definição das fronteiras do que viria a ser o Brasil, em um suposto esforço conjunto de demonstrar a inviabilidade do Tratado de Tordesilhas, foi amplamente divulgado na exposição por meio do grande número de mapas, muitos deles inéditos. ${ }^{6}$ Pode-se dizer que a cartografia era a alma das seções da exposição pensadas por Cortesão. ${ }^{7}$

O conjunto de comemorações dos 400 anos da fundação de São Paulo teve como objetivo primordial apresentar "ao mundo" uma cidade grande, rica, industrializada e líder de uma nação que ingressava nos "tempos modernos". O passado era evocado para legitimar o próspero presente e passava pela idealização e da criação do mito bandeirante, que vinha sendo alimentado desde as primeiras décadas do século XX pelos historiadores e instituições locais. Apesar de já ser revisto no âmbito acadêmico, Cortesão frequentemente buscava reabilitá-lo, questionando as críticas que eram feitas ao movimento sertanista. ${ }^{8}$

Um estudo detalhado sobre o conjunto das iniciativas promovidas a partir da Prefeitura de São Paulo e pela autarquia Comissão do IV Centenário da Cidade de São Paulo foi feito por Sílvio Lofego (2004). O trabalho permite compreender a multiplicidade de significados encerrados na imagem que então se construía para a cidade de São Paulo, que se tornava a mais populosa do país e buscava inscrever-se como capital cultural e símbolo de progresso nacional.

Segundo Leonzo, o historiador não teria deixado de lado a sua posição em uma questão candente das construções ideológicas e intelectuais brasileiras desde os anos 1930, que diz respeito ao caráter da colonização portuguesa e à mestiçagem. Da Introdução à história das bandeiras (1975), Leonzo destaca o louvor de Cortesão à ação colonial, geradora de uma "aliança luso-tupi" em forma de compadrio, desprezando uma historiografia que evidenciava a tirania dos portugueses em relação aos índios e

\footnotetext{
${ }^{6}$ Oliveira, D., Barros, L., Yoshimoto, C. No IV centenário da cidade de São Paulo. In: Prelo, Lisboa, n. esp., dez. 1984, p. 130.

${ }^{7}$ A Exposição de História de São Paulo no quadro da História do Brasil era dividida em nove seções. As seis primeiras ficaram a cargo de Cortesão e as três finais a cargo de seus auxiliares diretos, Mário Neme, Ernani Silva Bruno e Hélio Damante, com o auxílio de Agostinho da Silva.

${ }^{8}$ Entre os trabalhos de Cortesão dedicados à temática das bandeiras e bandeirantes, especialmente em Raposo Tavares e a formação territorial do Brasil (1958), o autor se referia a interpretações injustas do fenômeno das bandeiras, sobretudo no caso de Raposo Tavares, como mostra LEONZO, N. O "mistério" das Bandeiras. In: Prelo, Lisboa, n. esp., dez. 1984.
} 
índias. A historiadora indica, nesse sentido, que a distância entre Cortesão e Gilberto Freyre é curta, considerando as caracterizações da psicologia do colonizador e da mestiçagem. ${ }^{9}$ Seguindo a trilha dessa afirmação, é relevante buscar compreender a obra de Cortesão no/sobre o Brasil levando em conta o debate português (inclusive e fundamentalmente ouvindo a voz das então colônias), e a ideologia do lusotropicalismo, no qual a questão colonial era cada vez mais urgente. ${ }^{10} \mathrm{O}$ pensamento de Freyre dialogava com problemas amplamente discutidos em Portugal e oferecia argumentos para debater a miscigenação, as relações interculturais e a dinâmica colonial/imperial, inadiáveis no contexto posterior à Segunda Guerra e foi apropriado de modo a encaixar-se aos objetivos do regime ditatorial e adequar-se ao nacionalismo português - e à autoimagem daquele país. ${ }^{11} \mathrm{~A}$ partir disso, é fundamental perceber estas aproximações e compreendê-las dentro do quadro das implicações políticas que tiveram naquele contexto.

Complementando essa dinâmica de relações entre culturas e caracterizando a experiência colonial, os trabalhos de Sérgio Buarque de Holanda, dentro do mesmo contexto de Cortesão, que se tornaram clássicos da historiografia das expedições sertanistas, e de John Manuel Monteiro, na década de $1990^{12}$, são importantes contribuições no que diz respeito às bandeiras, contrariando a escrita mitológica que tinha se consolidado no início do século passado. Nessas obras, firmava-se uma escrita do despovoamento dos sertões, para captura de povos indígenas e para a construção de uma sociedade cujas relações eram marcadas pelo conflito, pelas alianças, pela resistência, pelas apropriações e pelas trocas nem sempre simétricas. Entre outros autores e trabalhos, esses também possibilitam uma leitura da historiografia da colonização portuguesa que considera os percursos formadores das narrativas e interpretações sobre os contatos entre sociedades distintas, bem como os impactos delas na estruturação das relações étnico-raciais e sociais e, inclusive, na

\footnotetext{
${ }^{9}$ LEONZO, N. Op. cit., 1984, p. 121; 124.

${ }^{10} \mathrm{O}$ debate sobre a autodeterminação dos povos estava na ordem do dia no contexto do pós-guerra. Em pouco tempo, o continente africano passaria a contar cada vez mais países independentes, sobretudo a partir do ano de 1960. Segundo Lincoln Secco (2002), o fim do Estado Novo português, a Revolução dos Cravos (1974) e as independências das então colônias portuguesas na África estão encerrados num mesmo processo.

${ }^{11}$ A esse respeito, os trabalhos de ConCeIÇão NeTo, M. (1997) e CASTELo, C. (1998), entre outros que serão citados oportunamente, são fundamentais para compreender as dinâmicas do pensamento luso-tropicalista, sua apropriação política e a oposição que contra ele se deu.

${ }^{12}$ As obras são, preponderantemente, Caminhos e Fronteiras (1956) e Negros da terra: indios e bandeirantes nas origens de São Paulo (1994), entre outras, que se debruçam, sobretudo, nas relações sociais entre povos europeus e de outros continentes no contexto da colonização portuguesa.
} 
própria construção da cultura histórica, isto é, da forma de relacionar-se com o passado, das sociedades originadas a partir desses contatos.

A partir da análise das condições de produção intelectual de Jaime Cortesão ao longo de seu exílio no Brasil, esta pesquisa tem como objetivo compreender como o historiador trilhou os seus percursos. As escolhas do autor passam pelas possibilidades que se apresentaram, diante de um quadro em que a burocratização do trabalho intelectual foi marcante e necessária aos que buscassem divulgação de resultados de pesquisas. Analisando, portanto, a atuação de Cortesão junto ao Ministério das Relações Exteriores e na Biblioteca Nacional, e a partir disso debruçando-se sobre questões basilares para as políticas do Estado Novo, é possível compreender como o intelectual português se envolveu nos debates locais e em que ponto pesaram as ideias que trouxe de suas experiências em Portugal, França, Espanha etc., e dos projetos políticos que lá desenvolveu, ao escrever a história do Brasil.

Quanto à Exposição de história de São Paulo no quadro da história do Brasil, durante as comemorações do quarto centenário da capital paulista, ela é aqui compreendida como uma expressão visual/tridimensional dos trabalhos desempenhados por Cortesão nos seus primeiros anos no país, veiculando por meio de uma linguagem específica e para um público bastante diversificado, suas considerações a respeito da colonização portuguesa do Brasil, antes apresentadas a públicos restritos. A escolha dos temas e a forma de apresenta-los indicam como o curador a equipe por ele dirigida pretendiam que um público amplo conhecesse as histórias de São Paulo e do Brasil. A partir da análise da representação da trajetória paulista/brasileira, do passado à modernidade, busca-se a compreensão da sua relação com os debates vividos na cidade e no país, articulados à experiência da industrialização e da modernização, que direcionam o olhar que é lançado ao passado. Além disso, nesse ponto pode ser identificado o peso das experiências e projetos trazidos por Cortesão, assim como identificar as consequências desse trabalho museológico em projetos posteriores, como o do Museu dos Descobrimentos que seria instalado em Lisboa.

Ao analisar os percursos das escritas de Jaime Cortesão durante sua estadia no Brasil pretende-se avaliar como as condições sociais marcaram a sua produção intelectual, além de tornar visíveis a circulação de ideias entre diferentes grupos, os debates nos quais se inseriu e os diferentes projetos e anseios - do Estado Novo 
brasileiro, da cidade de São Paulo, entre tantos outros, dos quais tomou parte ao longo de sua experiência de exílio -, relacionados ao seu próprio projeto, dedicado sobretudo a Portugal. A interdependência entre a produção de Cortesão e esses projetos, além da questão da identidade nacional frente à modernidade, fornece chaves para a leitura desse período da história brasileira, pródigo nos debates e na produção intelectual, cujas afiliações são percebidas em discursos e ideias ainda hoje discutidos e não totalmente superados, como a questão da mestiçagem, frequentemente utilizada como negação do racismo estruturante da sociedade brasileira. ${ }^{13}$

A produção historiográfica de Jaime Cortesão que foi resultado de suas experiências no Brasil será vista especialmente a partir de sua visualidade/tridimensionalidade expressa na Exposição de História de São Paulo. Considerando que o seu realizador se serviu do resultado de pesquisas anteriores ou em andamento para compor o quadro apresentado no Parque Ibirapuera em 1954, a abordagem expográfica dos assuntos trabalhados por Cortesão será o ponto de partida para compreender o percurso de sua escrita histórica, levando em conta inclusive o encadeamento da narrativa tal como se dá na exposição. Além disso, serão tratadas questões pontuais, especialmente em relação à mestiçagem e às supostas especificidades da colonização portuguesa, buscando a compreensão de suas afirmações a partir da análise das ideias em circulação a respeito do colonialismo, seja de um passado distante, seja do presente. Tal abordagem não desconsidera o contexto institucional em que as obras foram escritas e, nesse sentido, é importante situá-las.

Das obras de Cortesão produzidas e publicadas a partir das estruturas do Estado em que trabalhou - os Ministérios da Educação e das Relações Exteriores aos quais vinculavam-se a Biblioteca Nacional e o Instituto Rio Branco, pode-se visualizar um conjunto, do qual fazem parte Alexandre de Gusmão e o Tratado de Madrid (1750) (década de 1950); História do Brasil nos velhos mapas (1965); Raposo Tavares e a formação territorial do Brasil (1958). Da mesma forma, insere-se nesse conjunto o trabalho de organização documental e as introduções escritas para os Manuscritos da Coleção De Angelis, cujos volumes são Jesuitas e Bandeirantes no Guairá (1594-1640)

\footnotetext{
${ }^{13}$ SCHWARCZ, L. M. Nem preto nem branco, muito pelo contrário: cor e raça na intimidade. In: História da Vida Privada no Brasil: Contrastes da intimidade contemporânea. v. 4. São Paulo: Companhia das Letras, 1998.
} 
(1951), Jesuitas e Bandeirantes no Itatim (1596-1760) (1952), Jesuitas e Bandeirantes no Tape (1615-1641) (1969); Jesuitas e Bandeirantes no Uruguai (1611-1758) (1970) ${ }^{14}$, Tratado de Madri, antecedentes: Colônia do Sacramento (1669-1749) (1954); Antecedentes do Tratado de Madri: Jesuitas e Bandeirantes no Paraguai (1703-1751) (1955); Do Tratado de Madri à Conquista dos Sete Povos (1750-1802) (1969).

Além desse grupo, situo os textos relacionados à Exposição de História de São Paulo e a outros temas, publicados a partir da rede de relações de Cortesão ou mesmo reunidos postumamente. São eles A Carta de Pero Vaz de Caminha (1943) e A fundação de São Paulo: capital geográfica do Brasil (1955), estudos concebidos por Cortesão; O Humanismo Universalista dos Portugueses (1965) e Introdução à história das Bandeiras (1975), que são compilações póstumas de textos do autor.

Em um sentido geral, as obras foram escolhidas a partir dos temas, priorizando a cartografia histórica e as bandeiras, temas em que são marcantes as relações entre portugueses, sociedades indígenas e a população que se formou a partir destes contatos, fontes fundamentais para compreender suas abordagens da colonização portuguesa na América do Sul. ${ }^{15}$

A operação historiográfica realizada por Cortesão ao escrever seus trabalhos pode ser lida a partir dos conceitos desenvolvidos por Certeau, compreendendo as três esferas que identifica: o lugar, a prática e a escrita. Partindo do lugar de onde fala o historiador (Estado, instituição etc.), levam-se em conta os constrangimentos que se lhe impõem - ou seja, o conjunto de fatores que condiciona o trabalho dentro de uma perspectiva mais ampla: "[o lugar] torna possiveis certas pesquisas em função de conjunturas e problemáticas comuns". A prática diz respeito à instrumentação que permite ao historiador transformar o dado em criado, e se refere a um conjunto de técnicas que auxiliam a história. ${ }^{16} \mathrm{~A}$ terceira esfera da operação historiográfica - a escrita - é por sua vez o meio pelo qual são recuperáveis não apenas o lugar e a prática como também os diversos outros componentes da produção, tais como as relações sociais e as sensibilidades de quem a produziu. Partindo desses referenciais

\footnotetext{
${ }^{14}$ Esse volume tem introdução, notas e sumário feitos por Hélio Vianna, que concluiu o trabalho iniciado por Cortesão.

${ }^{15}$ A intenção aqui não será a de compreender as características das obras de Cortesão e sim as linhas mestras do percurso de sua escrita histórica, à luz das atividades que desempenhou como um intelectual presente no espaço público, na imprensa, na organização de uma exposição de grande alcance.

${ }^{16}$ CERTEAU, M. A escrita da história. Rio de Janeiro: Forense Universitária, 1982, p. 77-79; 81. Grifos do autor.
} 
e aliando-os a outros, que considerem a escrita histórica que se dá a partir da visualidade da cartografia histórica (uma das principais fontes documentais) e da museologia (ao mesmo tempo suporte de divulgação da produção histórica e escrita histórica), é possível construir uma interpretação sobre os percursos da narrativa de Cortesão.

De acordo com Manoel Luís Salgado Guimarães (2007), ao considerar a relação com o tempo das sociedades contemporâneas, é necessário não somente refletir sobre a escrita histórica em seu sentido acadêmico como também pensar sobre os usos do passado em nossa contemporaneidade. Para o autor, isso implica pensar "em formas peculiares de visibilidade para esse passado, entendendo-a como parte de uma estratégia social e política", o que por sua vez leva à reflexão sobre o patrimônio, uma das formas possíveis de produção dessa visualização. A expressão material das sociedades passadas, a partir de sua qualificação enquanto patrimônio, permite que se lhe dê um novo significado, admitindo que sejam lançados aos objetos um olhar que os perceba de forma diferente do contexto em que foram criados. Para Guimarães, uma vez "reinscritos e lidos sob nova chave, viabilizam formas peculiares de visualidade para o passado", formas essas que respondem às necessidades do presente que é o ponto de partida dessa operação. Guimarães traz à discussão a definição de Pomian, segundo o qual uma coleção qualquer de objetos naturais ou artificiais, temporária ou definitivamente fora do circuito das atividades econômicas, protegidos em local fechado e preparado para essa exposição, está dando uma centralidade ao olhar. Para o autor, uma vez "dispostos segundo uma gramática, os objetos (...) estão ali para serem vistos e viabilizam uma relação entre o visível e o invisível, seja esse concebido temporal ou espacialmente". ${ }^{17}$

Tomando as fontes visuais - a cartografia - como relevantes tanto à escrita histórica de Jaime Cortesão no/sobre o Brasil quanto em suas escolhas para construir a Exposição de História de São Paulo no quadro da História do Brasil, esta pesquisa trabalha com a hipótese de que os percursos da escrita histórica do intelectual português giram em torno da visualidade do processo histórico: não só as fontes que mais utilizava como a exposição que reuniu praticamente todas as suas pesquisas anteriores dão lugar de destaque ao olhar. Cabe então discutir essa possibilidade de leitura de sua

\footnotetext{
${ }^{17}$ Guimarẽes, M. L. S. Vendo o passado: representações e escrita da história. In: Anais do Museu Paulista, São Paulo, v. 15, n. 2, jul.-dez. 2007, p. 17-21.
} 
trajetória levando em conta as relações que estabeleceu com essas fontes e linguagens.

Tendo em vista também o universo em que Cortesão trabalhou e os projetos de nação concebidos entre as décadas de 1930-1950 no Brasil, marcados pela cara questão da mestiçagem ou da coexistência das três raças ${ }^{18}$ - e os discursos produzidos a partir de então, faz-se necessário buscar a compreensão deste debate para além da ideia homogeneizante da diferença, muitas vezes interessada em eliminar a existência do conflito. Segundo Maria da Conceição Neto (1997), a ideia do "português típico", recorrente na produção daquela época e com ressonâncias no presente, impede de perceber as dimensões históricas do colonialismo e reproduzem muitas vezes um discurso concebido a partir de modelos autoritários e unilaterais, cujas teias ainda precisam ser rompidas. Mesmo em indivíduos cuja trajetória de vida foi marcada pela contestação de regimes de exceção - como foi o caso de Cortesão , há muitas vezes a convergência de ideias entre eles e o que combatem. Nessa perspectiva, Edward Said ${ }^{19}$ propõe uma leitura que leve em conta as ambivalências do pensamento e a dialética entre o texto/autor e a "complexa formação coletiva para a qual a sua obra é contribuição". ${ }^{20}$

Para a análise das atividades de Cortesão em um sentido mais amplo, foi fundamental a documentação do espólio Jaime Cortesão, que está sob guarda do Arquivo de Cultura Portuguesa Contemporânea da Biblioteca Nacional de Portugal. O Espólio Jaime Cortesão foi comprado pelo Estado por meio do Instituto Português do Livro em 1985. O objetivo era o de integrar o acervo do Museu da Literatura, projeto em processo de instalação. A partir de acordo firmado com a sua viúva, Carolina Cortesão, o espólio só seria transferido ao Estado caso fosse reconhecida a plena capacidade de funcionamento do referido museu, caso contrário, ficaria para a Biblioteca Nacional. A inviabilidade do museu foi reconhecida em 1991, quando na pessoa de Maria da Saudade Cortesão, a filha, foram entregues o espólio e a biblioteca do autor à Biblioteca Nacional de Portugal.

\footnotetext{
${ }^{18}$ A questão da mestiçagem, ou da ideia das "três raças" formadoras da nacionalidade brasileira, tem um largo histórico de debate. Relaciona-se à proposta de Karl von Martius, vencedora do concurso promovido pelo IHGB, de "Como se deve escrever a história do Brasil", tempo após a sua criação em 1838. Sobre essas questões referentes à historiografia brasileira cf. GUIMARÃES, 1988; REIS, 2007.

${ }^{19}$ Refiro-me aqui especialmente a duas de suas obras: Orientalismo: o Oriente como invenção do Ocidente, de 1978; e Cultura e Imperialismo, de 1993.

${ }^{20}$ SAID, E. Orientalismo: o Oriente como invenção do Ocidente. São Paulo: Companhia das Letras, 2007, p. 35 .
} 
A primeira organização do arquivo foi feita por Carolina Cortesão, que além de ter colaborado na datilografia dos originais, agrupou alguns textos em envelopes ou maços, ora fazendo menção individualizada, ora indicando apenas o tema dominante. Nem sempre os conteúdos correspondiam ao que se indicava; a segunda exploração ficou a cargo dos responsáveis pela edição das Obras Completas de Cortesão (Portugália Editora, 1964-1971 e Livros Horizonte, 1975-1985), que buscaram reagrupar tematicamente os principais textos esparsos ou inéditos. Desde a data da morte de Cortesão até meados da década de 1980, diversos projetos editoriais foram ensaiados, o que marcou a organização do espólio, ainda que alguns tenham permanecido como o autor havia deixado.

Os textos datilografados e impressos emendados por Cortesão correspondem às sucessivas versões de textos publicados em vida. Boa parte foi datilografada por sua esposa, Carolina Cortesão, sob direção do autor e/ou sujeitas à sua correção. Há textos, segundo o inventário, que constituem preparação de edições póstumas, com ou sem a intervenção de sua viúva. Desses não é possível identificar a vontade expressa pelo autor, seja na fixação do texto, seja na respectiva seleção para publicação. Os recortes de imprensa têm, em vários casos, emendas do autor, de modo a constituírem o texto base para um ou mais títulos a publicar. Há alguns títulos genéricos (como Cartas do Brasil, Cartas de Portugal, Portugal, a terra e o homem) que apresentam conteúdo escasso ou mesmo eventual abandono.

Todos os documentos, considerando as suas principais características, foram agrupados por temas em duas séries principais: a de textos qualificados como literários (poesia, prosa e história e crítica) e a dos textos considerados como históricos (incluindo todos os trabalhos de pesquisa e interpretação histórica com destaque para a História de Portugal em geral e História da Cartografia em particular). Sob a rubrica Vária foram agrupados os documentos em conjuntos Literatura, Arte, História, Ficheiros e Notas.

$\mathrm{Na}$ série Correspondência, com pouco mais de 900 documentos, seguiu-se o padrão de classificação, de correspondências remetidas e recebidas. $O$ instrumento de consulta faz a ressalva de que "o epistolário recebido e conservado por Jaime Cortesão é escasso e circunscreve-se, predominantemente, aos anos cinquenta, o que permite supor que o historiador tenha perdido grande número de cartas recebidas antes do exílio no Brasil". Em Documentos Anexos de Jaime Cortesão destacam-se 
títulos, contratos, recibos, impressos, recortes de imprensa e fotografias (entre as fotografias, 88 são da Exposição do Mundo Português, de 1940; 29 são da Exposição de História de São Paulo, de 1954 e 9 são de viagens no Brasil, sem data). Nas Correspondências de terceiros há uma subsérie dedicada às missivas de pêsames e homenagens, ordenando 923 documentos enviados à Carolina Cortesão e a outros familiares a título de pesar e respeito quando da morte do escritor ou em outras ocasiões de homenagem.

Uma segunda parte do espólio deu entrada na Biblioteca Nacional de Portugal em 2002. Os documentos foram preparados por Irene Cortesão e não estão totalmente identificados ou catalogados. No conjunto, destacam-se recortes, mapas, projetos, textos datilografados de seus cursos no Itamaraty e correspondências, planos e o Catálogo da Exposição de História de São Paulo no Quadro da História do Brasil, nunca publicado. ${ }^{21}$

Esses documentos fornecem não apenas informações sobre a rede de sociabilidade do autor quando esteve no Brasil - a maior parte da documentação diz respeito àquela época - como também permite aprofundar o entendimento das características da sua atuação no Ministério das Relações Exteriores, na Biblioteca Nacional do Rio de Janeiro, na imprensa brasileira, nas conferências, na organização da Exposição de História de São Paulo. Essa documentação é fulcral para a percepção das sensibilidades ideológicas ou culturais comuns, as afinidades, as estruturas de sociabilidade, as mudanças de posição, as ideias em movimento, tal como aponta Sirinelli (2003). Considerando o grande volume, foram selecionados para uma análise mais detida os documentos referentes à sua trajetória brasileira e no interior destes, as indicações que permitiram cartografar as suas sociabilidades, as condições de sua produção no Brasil e os percursos de sua escrita histórica, objetivos centrais deste trabalho.

Em relação à documentação da Exposição de História de São Paulo, além dos documentos citados do Espólio Jaime Cortesão, em Lisboa, há a Coleção IV Centenário da Cidade de São Paulo, sob guarda do Museu Paulista da Universidade de São Paulo, dividida em documentação textual e iconográfica, e abrange não só a exposição

\footnotetext{
${ }^{21}$ Inventário do Espólio Jaime Cortesão (BNP/ACPC, 1994). O instrumento se refere à primeira parte adquirida em 1985, contando pouco mais de três mil documentos; a segunda parte, adquirida em 2002, conta com um Guia Preliminar.
} 
como outros eventos relacionados às comemorações. A primeira parte, com 490 documentos, é composta pelo projeto geral e guia das sessões, relação de documentos doados e emprestados à Comissão, material de imprensa, atas de recebimento de documentos, relação de documentos solicitados a diversas instituições, correspondência. Cópias de documentos que foram expostos também se encontram na coleção, tais como bulas papais, regimentos, pareceres, decretos, resoluções imperiais, Constituições, frontispícios de obras sobre assuntos diversos. A segunda parte, iconográfica, contém 686 itens, em grande parte reproduções de documentos ou fotografias de personalidades em exposição ou ainda registros de eventos relacionados à efeméride, como a inauguração da Catedral Metropolitana de São Paulo e do Parque Ibirapuera, ambos ocorridos em 1954.

A documentação referente à exposição e ao conjunto das comemorações do Quarto Centenário da cidade de São Paulo, como o catálogo, roteiros de visitação, processos, correspondências, reproduções fotográficas/iconográficas, documentos que foram expostos, serve para situar a organização, o planejamento e a execução das tarefas dirigidas por Cortesão, demonstrando as escolhas, a construção da narrativa expográfica e os objetivos frente ao público que a visitaria. Na dificuldade de rastrear a recepção do público, ficam apenas alguns exemplos de críticas positivas e negativas recebidas pelo organizador, na imprensa ou por outros meios, e eventualmente respondidas.

Complementando o perfil intelectual de Jaime Cortesão e da sua produção ao longo do exílio no Brasil, este trabalho discute algumas das questões por ele levantadas e busca identificar as suas consequências, a partir da forma como outros autores a observaram e compreenderam, a fim de perceber como as ideias circularam e quais discursos e práticas elas buscaram construir e sustentar. O exercício de análise da trajetória do intelectual português parte das discussões sobre a história intelectual/das ideias, área em que a problematização da escrita biográfica deve ser um pressuposto para a apreensão adequada das trajetórias pessoais/intelectuais, vistas para além dos perfis muitas vezes lineares, coerentes e acabados que abrem mão de olhar para as aparentes contradições e os constrangimentos, presentes na vida de qualquer sujeito.

Benito Schmidt (1997), ao discutir as biografias produzidas por jornalistas e historiadores nas últimas décadas, levanta questões bastante pertinentes da prática, como a necessidade de investigar as informações retiradas das fontes, vistas a partir 
de seus locais e mecanismos de produção. Nesse sentido, as falas de depoentes devem ser consideradas leituras da realidade para além de simples dados. Assim sendo, seriam levados em conta "os complexos processos de recriação do passado, as relações entre o lembrar e o esquecer (...)". Schmidt também pondera sobre as biografias que pretendem observar facetas diferenciadas dos sujeitos para além da vida pública e dos feitos notáveis. Nos trabalhos em que essa dimensão está em cena, emergem "os sentimentos, o inconsciente, a cultura, a dimensão privada e o cotidiano". Dos trabalhos que cita como exemplos dessa forma de escrita, o autor lembra de Georges Duby e Carlo Ginzburg, respectivamente autores de Guilherme Marechal ou o melhor cavaleiro do mundo (1993) e O queijo e os vermes (1987). Em ambos os trabalhos, os sujeitos biografados - tanto o personagem-título do trabalho do medievalista francês quanto Menocchio, o réu do processo inquisitorial do texto do historiador italiano - são vistos em seus múltiplos aspectos, públicos e privados. $\mathrm{Na}$ historiografia brasileira, Schmidt destaca o trabalho de Maria Elena Bernardes, de 1994, sobre a militante Laura Brandão. Na pesquisa, a autora investigou a vivência da personagem em uma perspectiva de gênero, buscando compreender como as suas vidas pública e privada se influenciaram ou se alteraram. ${ }^{22}$

A perspectiva de análise sugerida por Benito Schmidt traz à tona a cada vez mais forte contestação à "concepção do indivíduo como ser unitário, que atravessa linearmente o período de uma vida", discutindo em seu texto pontos de vista como o de Michel de Certeau (1982), que sustenta que cada pessoa deve ser entendida enquanto um locus no qual incoerências e contraditórias pluralidades interagem, e Pierre Bourdieu, que se opõe àquilo que denomina "ilusão biográfica", uma noção de identidade interpretada como constância e responsabilidade plena, oposta ao sujeito fracionado e múltiplo que mais corresponde à vida real. ${ }^{23}$

Pierre Bourdieu (1996) expressa o seu ponto de vista sobre a construção de escritas biográficas partindo da discussão sobre o suporte/substância que representa

\footnotetext{
${ }^{22}$ SCHMIDT, B. B. Construindo biografias... Historiadores e jornalistas: aproximações e afastamentos. In: Estudos Históricos, Rio de Janeiro, n. 19, 1997, p. 6; 9; 13. Para além desta reflexão, elenco também diversos estudos que têm contribuído para a história intelectual, ao mesmo tempo em que ampliam as perspectivas de análise sobre a historiografia brasileira do ponto de vista das dinâmicas da produção do conhecimento, como IUMATti, P. T. Caio Prado Júnior: uma trajetória intelectual. São Paulo: Brasiliense, 2007; Nicodemo, T. L. Urdidura do vivido: Visão do Paraíso e a obra de Sérgio Buarque de Holanda nos anos 1950. São Paulo: Edusp, 2008; RODRIGUES, L. S. Florestan Fernandes: interlúdio (19691983). São Paulo: Hucitec, 2010.

${ }^{23}$ SCHMIDT, B. B. Op. cit., 1997, p. 13.
} 
o nome próprio, em torno do qual se articulam diversas propriedades e se constrói a identidade social. Para o sociólogo francês, a tentativa de compreender uma vida "como uma série única e por si suficiente de acontecimentos sucessivos", cujo vínculo é apenas a associação a um sujeito representado pela constância do seu nome próprio, é um absurdo que não leva em conta a estrutura da rede de relações e seus laços de interdependência. Ainda segundo o autor, não se pode compreender uma trajetória ${ }^{24}$ sem que se tenham construído primeiramente "os estados sucessivos do campo $^{25}$ no qual ela se desenrolou", assim como o "conjunto das relações objetivas que uniram o agente considerado (...) ao conjunto dos outros agentes envolvidos no mesmo campo e confrontados com o mesmo espaço dos possíveis". ${ }^{26}$

As relações de força que Cortesão encontrou no Brasil, sejam no campo intelectual ou no político, não estão alheias ao Estado Novo, regime autoritário vigente de 1937 a 1945, instituído pelo presidente Getúlio Vargas, no poder desde 1930. Para Sérgio Miceli (2001), que analisa o contexto intelectual na chamada Era Vargas, os intelectuais que eram "recrutados pelo regime (...) assumiram as diversas tarefas políticas e ideológicas determinadas pela crescente intervenção do Estado nos mais diferentes domínios de atividade". No período posterior ao fim do Estado Novo, convencionalmente chamado de populista (1945-1964), é notável uma "ampliação das carreiras reservadas aos intelectuais ao mesmo tempo em que se intensifica o recrutamento de novas categorias de especialistas", diversos deles se alçando a postos-chave na esfera da administração, dos quais se excluíam outros grupos de intelectuais e especialistas "que resistiram à implantação das diretrizes e dos programas adotados pela nova coalizão dominante nos últimos quinze anos em que os militares se apoderaram do controle do Estado". A área da cultura era um "negócio oficial", com orçamento próprio, que criava uma intelligentsia e intervinha "em todos os setores de produção, difusão e conservação do trabalho intelectual e

\footnotetext{
${ }^{24}$ A trajetória é entendida pelo autor como "o envelhecimento social que, embora o acompanhe de forma inevitável, é independente do envelhecimento biológico" (BOURDIEU, 1996, p. 190).

${ }^{25}$ De acordo com o próprio autor, o conceito de campo diz respeito a um sistema de linhas de força, ou seja, um complexo no qual "agentes ou sistemas de agentes que o compõem podem ser descritos como forças que se dispondo, opondo e compondo, lhe conferem sua estrutura específica num dado momento do tempo" (BOURDIEU, 1968, p. 105). Ao longo do texto, recorrerei a outras noções deste autor e que se demonstram pertinentes no estudo da história intelectual.

${ }^{26}$ BOURDIEU, P. A ilusão biográfica. In: FERREIRA, M. e AMADO, J. (org.). Usos e abusos da História Oral. Rio de Janeiro: Ed. FGV, 1996, p. 188-190.
} 
artístico". ${ }^{27}$ Em troca das possibilidades oferecidas pela administração federal, os intelectuais que dela se aproximavam deviam "se curvar às diretrizes políticas do regime" ou abrigar-se "sob a postura de uma 'neutralidade' benevolente em relação ao Estado", o que lhes permitiu manter-se a salvo das lutas políticas. ${ }^{28}$

A partir dos trabalhos sobre o contexto do regime, no que se refere aos intelectuais e ao universo da cultura, nota-se a centralidade que ocupam artistas, escritores, intelectuais de várias vertentes do movimento modernista, alçados ao protagonismo sob o programa cultural da Era Vargas. ${ }^{29} \mathrm{O}$ vínculo de Cortesão com esses sujeitos, que extrapola o espaço da administração pública, fornece elementos para identificar e compreender as afinidades entre pessoas, ideias, projetos, gostos, visões de mundo e estratégias de ação política e cultural, bem como compreender e identificar as dinâmicas da produção cultural e do conhecimento naquele contexto.

No primeiro capítulo, Cortesão e o Brasil: exílio, sociabilidades e condições da produção intelectual, são abordadas as condições da produção intelectual de Cortesão no Brasil, tendo como ponto de partida a sua relação com a escrita histórica. Nesse sentido, cabe conhecer quem era o sujeito a aportar no Rio de Janeiro em fins do ano de 1940, identificando a sua trajetória familiar, intelectual, institucional, sua vida política, seus anseios e projetos, suas relações. Das suas relações, destaca-se a circulação de intelectuais entre instituições portuguesas e brasileiras, bem como o grau de organização de seus conterrâneos no Brasil, inclusive com casas editoras próprias. Tais sociabilidades são a matéria-prima para entender o processo adptação ao novo país, tanto na então Capital Federal quanto na cidade de São Paulo.

No que diz respeito ao contexto político brasileiro - o do Estado Novo - fazse necessário avaliar o seu programa cultural e o papel que se esperava dos intelectuais naquele debate. No caso de Cortesão, além de ser presença constante na imprensa, frisam-se as suas atuações na Biblioteca Nacional e no Ministério das Relações Exteriores, ocupações que não eram vazias de significado naquele quadro, abrangendo também questões de diplomacia e soberania territorial. Em suma, a

\footnotetext{
${ }^{27}$ MiCELI, S. Intelectuais à brasileira. São Paulo: Companhia das Letras, 2001, p. 197. Segundo o autor, esse processo levou a uma intensa burocratização e profissionalização das carreiras intelectuais, pois as instâncias e atividades relacionadas ao poder público eram reais possibilidades de retorno financeiro e também de reconhecimento.

${ }^{28}$ MiCELI, S. Op. cit., 2001, p. 237.

${ }^{29}$ Velloso, M. P., 1993 e 2003; Gomes, A. M. C., 1998 e 2000; PANdolfi, D., 1999; BomenY, H., 2001.
} 
discussão aponta para a caracterização de um historiador luso-brasileiro, considerando a sua produção historiográfica, suas declarações sobre o período em que viveu no Brasil e os relatos, distinções e honrarias recebidas de pessoas ou de instituições locais.

O segundo capítulo, Percursos da escrita histórica: a narrativa da conquista do sertão dentro e fora de uma oca, propõe uma outra camada de leitura da atuação de Cortesão no Brasil, tendo como centro da interpretação a Exposição de História de São Paulo no quadro da História do Brasil, montada entre 1954 e 1955 no interior do edifício hoje denominado como Oca (Pavilhão Governador Lucas Nogueira Garcez), no Parque Ibirapuera. Entendendo o planejamento e a montagem da exposição - especialmente das seis primeiras seções - como uma forma de dar visualidade e tridimensionalidade aos aspectos trabalhados nas suas pesquisas, é possível mobilizar parte significativa de sua produção historiográfica no/sobre o Brasil. A partir disso, problematiza-se a narrativa da colonização dada a partir da fundação da vila de Piratininga no planalto, marcando o início na conquista do sertão e a busca pelo Rio da Prata através do interior do continente. A formação territorial do Brasil, conceito frequente na obra brasileira do historiador, pode assim ser vislumbrada tanto no contexto dos cursos oferecidos no Instituto Rio Branco quanto no da comemoração do aniversário de São Paulo. Em ambos, o fenômeno das bandeiras é um denominador comum, comungando assim em larga medida com parte da historiografia brasileira, especialmente aquela das elites paulistas, e ainda, no quadro da História do Brasil, com as políticas de integração nacional, de valorização do interior e de defesa das fronteiras promovidas desde a década de 1930 pelo Governo Federal.

A exposição, entendida em seus discursos, imagens, montagem e no que é possível inferir da relação com o público, permite mobilizar também, além da visualidade das obras historiográficas do autor, a parte que cabe aos elementos portugueses (e europeus) à formação do Brasil, assim como aos indígenas, lembrados tão-somente por sua cooperação com o elemento adventício e aos africanos e afrobrasileiros, quase ausentes da narrativa. Encerrando diversas projeções, de paulistas, de brasileiros, de portugueses com Cortesão, a exposição histórica de 1954 permite identificar convergências entre todos os sujeitos implicados diretamente em sua consecução, entendida, tal como o conjunto das comemorações centenárias, no marco do ingresso da cidade e do país na modernidade, representada inclusive nas 
escolhas estéticas dentro e fora do conjunto arquitetônico de Niemeyer, com a participação de Portugal na figura de Cortesão, presença que não passou ilesa das críticas.

No capítulo final, Uma historiografia das relações: especificidades da colonização portuguesa, poder e produção do conhecimento, outra camada da escrita histórica de Cortesão é discutida, considerando especialmente os debates em torno do problema da identidade nacional, fortemente marcados pela questão da mestiçagem. É imperativo olhar com mais vagar o frequente recurso à ideia de formação de uma "família luso-tupi" no planalto, presente tanto na escrita histórica quanto "museal" de Jaime Cortesão. Tal debate não se restringe ao Brasil e, desde os trabalhos e ações de Gilberto Freyre, se expande para Portugal e para as suas então colônias, não sem ir ao encontro de outras elaborações, sejam elas "científicas", "mitológicas" ou produtos do próprio senso comum.

A circulação de ideias no contexto da descolonização, vivido nos continentes africano e asiático e, no que é pertinente a este trabalho, nas regiões lusófonas ${ }^{30}$ apresenta elementos para discutir a recepção dos pressupostos sobre a colonização portuguesa tanto no passado quanto no presente, veiculados sobretudo em Portugal e no Brasil. De modo geral, esses pressupostos têm como base uma narrativa harmônica do contato entre os portugueses e os povos originais das regiões em que aportou desde o século XVI, se adequando a partir de seus supostos atributos de "plasticidade", "tolerância", "amorabilidade". Nesse quadro, são postas em evidência as ambivalências que a produção de Cortesão poderia ter naquele contexto, como sugerem publicações na imprensa angolana e moçambicana e a sua participação como vogal do Centro de Estudos Históricos Ultramarinos (CEHU), por exemplo.

O "luso-tropicalismo" de Freyre e o construído pelo salazarismo e o "humanismo universalista"/"amorabilidade franciscana" de Cortesão são interpretações que, avaliadas nesse quadro de relações, auxiliam na discussão sobre as implicações entre poder e produção do conhecimento, à medida em que ideias e interpretações como essas fossem frequentemente contestadas especialmente por intelectuais anticolonialistas africanos. Dessa forma, procuro analisar o que se

\footnotetext{
${ }^{30} \mathrm{Cabe}$ ressaltar que as regiões de língua portuguesa, no que diz respeito ao escopo deste trabalho, são as ainda colônias/províncias ultramarinas portuguesas na África, considerando a língua oficialmente adotada nessas regiões, a despeito da diversidade linguística que delas faz parte.
} 
esperava de Cortesão quando o Ministério do Ultramar o convidou para integrar o CEHU, levando em conta o papel que instituições como essa tiveram naquele contexto.

O exercício de reflexão caminha para a conclusão no intuito de identificar as permanências desse pensamento positivo sobre as relações entre portugueses e africanos ou índios sul-americanos no contexto da colonização, buscando elementos para discutir o que chamo aqui de "historiografia das relações" - narrativas e interpretações da dinâmica entre adventícios e nativos - a partir do qual são identificáveis fontes, tradições, divergências e permanências, cujas implicações se impõem não apenas sobre a produção do conhecimento como também para práticas políticas. Seguindo as considerações da historiografia recente que trata do "colonialismo tardio" 31 , torna-se relevante o questionamento dos impactos da produção do conhecimento sobre a colonização brasileira sobre a continuidade do colonialismo na África, partindo do pressuposto que o sucesso presente do Brasil seria uma prova da competência colonial portuguesa, credenciando-o para dar continuidade à sua ação em solo africano.

Sem pretender esgotar neste trabalho todas as questões que o tempo presente coloca sobre a relação entre o poder e a produção e a difusão do conhecimento (no caso, o histórico), busco, instigado pelas permanências do pensamento que ganhou corpo a partir do pós-guerra, no qual as propostas de cooperação internacional se impuseram como vias de solução diplomática de conflitos, abrir um caminho para problematizar o papel de organismos como a Comunidade dos Países de Língua Portuguesa (CPLP), bem como as universidades, as instituições culturais - como os museus - e as de pesquisa, no posicionamento frente às realidades comuns que foram engendradas pelos séculos de dominação colonial e pela apropriação dessas estruturas pelas elites que se formaram após as independências.

\footnotetext{
${ }^{31}$ Refiro-me aqui aos trabalhos de ConCeição Neto, M. (1997), CASTELo, C. (1998); AleXANDRe, V. (2000); THOMAZ, O. R., (2002), entre outros, que recaem sobre o convencionalmente chamado de Terceiro Império português, consequente à independência do Brasil.
} 


\section{CAPítulo 1. \\ Cortesão e o Brasil: exílio, sociabilidades e condições da produção intelectual}

\section{De Lisboa ao Rio, a bordo do S/S Angola, 1940: o passageiro e a bagagem}

Entre 1927 e 1957, Jaime Cortesão viveu grandes períodos fora de Portugal. Assinala-se nesse ínterim a sua dedicação à história portuguesa, a partir dos contatos que teve com os diversos arquivos dos países em que se instalou após ser demitido da direção da Biblioteca Nacional de Portugal, cargo que ocupava desde 1919. Ainda que sua obra inaugural de história tenha sido a dedicada ao estudo da expedição de Pedro Álvares Cabral e o descobrimento do Brasil, lançada em 1922, em homenagem ao primeiro centenário da independência brasileira, foi de fato durante as atividades de pesquisa nos arquivos de Espanha, França, Bélgica, Inglaterra, que Cortesão fez da história uma presença cada vez mais frequente de sua escrita. Em uma primeira etapa, entre 1927 e 1940, o autor se uniu a outros portugueses, autoexilados ou banidos após o golpe de Estado de 1926, em grupos empenhados, na França e na Espanha, em disputar a orientação da recém-proclamada República, a partir de então nas mãos de um regime ditatorial que perduraria até $1974 .{ }^{32}$ Desde antes da proclamação da República em 1910, o médico de formação já participava ativamente da vida cultural e política do país, tendo dirigido a Biblioteca Nacional de 1919 a 1927 a convite do presidente António José de Almeida. Foi demitido do cargo por ter participado de um movimento que tentava derrubar a ditadura instaurada em $1926 .{ }^{33}$

Jaime Cortesão chegou ao Brasil em fins de 1940 a bordo do S/S Angola, depois de ser banido de Portugal pelo regime salazarista. ${ }^{34} \mathrm{Na}$ ocasião, Cortesão e

\footnotetext{
${ }^{32}$ SANTOS, 1993; SERRÃO, 1984 e 1985 são alguns dos que destacam o período de exílio de Jaime Cortesão como dedicado especialmente à história de Portugal. Ao mesmo tempo, o período é diferenciado daqueles em que Cortesão atua política ou artisticamente.

${ }^{33}$ Jaime Cortesão foi nomeado diretor da Biblioteca Nacional de Portugal quando seu amigo Leonardo Coimbra era Ministro da Instrução. A indicação teria partido de Raul Proença que recusara o cargo, tornando-se depois chefe dos serviços técnicos e Álvaro Pinto dos administrativos. Os velhos companheiros, desde os tempos da Universidade do Porto, coordenaram trabalhos grandiosos a partir da estrutura do Estado (SANTOS, 1993, p. 89).

${ }^{34}$ Entre 1910 e 1926, Portugal passou da Monarquia à ditadura e o Estado liberal foi um simples interregno. Desde a proclamação em 1910, a República passou por uma crise econômica causada pela
} 
sua família viviam na França, mas a crescente ocupação do país pelo exército alemão no primeiro semestre de 1940 obrigou um grande número de pessoas, que naquele país já viviam na condição de refugiados ${ }^{35}$, a novamente buscar um lugar para se estabelecer. No caso dos emigrados portugueses, diante do crescimento do conflito, foi-lhes concedida anistia pelo governo ditatorial português, levando as autoridades consulares a permitirem o seu regresso. Grande parte dos portugueses que tinha emigrado para a França tinha ainda a possibilidade de escolher a Inglaterra, no entanto muitos, como Cortesão e alguns dos seus, optaram por retornar a Portugal. $\mathrm{Na}$ fronteira portuguesa, Cortesão e parte do grupo que com ele retornava foram detidos e levados à prisão. ${ }^{36}$

Ainda que o fato de ser historiador e preso político dê condições para entender a forma como Cortesão trabalhou no Brasil, próximo da comunidade de portugueses que já vivia no país - incluindo nela outras pessoas que também não eram bem quistas pelo governo de Salazar - é preciso buscar mais elementos para compreender o motivo pelo qual o historiador ganhou destaque dentro dessa comunidade, sendo alçado em muitos momentos à condição de seu representante. Além disso, outras evidências podem também iluminar o processo de sua integração ao campo intelectual brasileiro, no qual se tornou uma presença marcante. Dito de outra forma, é possível encontrar na bagagem do sujeito que aportou em fins de 1940 no Rio de Janeiro algumas das condições, os capitais simbólicos, para que se integrasse plena e relevantemente aos circuitos intelectuais brasileiros.

Em algumas das entrevistas concedidas pelo autor tanto no Brasil quanto em Portugal, vê-se um sujeito com uma narrativa bastante coesa entre passado/presente, identificando na infância e no ambiente familiar o nascimento do historiador em si. Cortesão era filho de um médico e de uma professora e nasceu em 1884, em uma pequena freguesia no norte de Portugal, nas cercanias de Coimbra. A região também é frequentemente considerada como responsável pela sua formação, que no Direito e na Medicina contou com um forte pendor para as artes. Segundo Santos, Cortesão

guerra e por sucessivas crises políticas que viram golpes, violações do regime constitucional, sete eleições e quarenta e cinco governos. Anos depois, em 1933, era instituído o Estado Novo, sob a liderança do chefe do Conselho de Ministros, António de Oliveira Salazar (SECCO, 2004, p. 50-51).

${ }^{35}$ Muitos haviam se refugiado na França durante a ascensão de governos antiliberais, autoritários e/ou totalitários na Europa. O país era buscado por conta dos mesmos valores da Revolução Francesa combatidos pelos regimes instaurados (HOBSBAWM, 1995, p. 118).

${ }^{36}$ Santos, A. R. Jaime Cortesão: um dos grandes de Portugal. Porto: Fundação Engenheiro Antonio de Almeida, 1993, p. 183-185. 
abriu mão do curso de Direito e saiu de Coimbra por conta do autoritarismo no ambiente universitário. Tanto ele quanto outros jovens optavam pelo Porto e por sua universidade porque à época a cidade nortenha seria um recanto liberal, sendo por isso escolhida por outros jovens estudantes de cidades com experiências educacionais autoritárias para fazer fluir as suas tendências poéticas e literárias, diz o biógrafo portuense. $^{37}$

De acordo com Cortesão, em entrevista provavelmente concedida em fins da década de 1950, três circunstâncias fundamentais teriam feito nascer em si o escritor: "a paisagem dos campos do Mondego", "o ambiente familiar" e "o de Coimbra". Do ambiente familiar, lembra que o pai, Antonio Augusto Cortesão, "acima de tudo filólogo", é a quem deve as primeiras tentativas de um Dicionário Histórico e Etimológico da Língua Portuguesa. Além disso, o autor salienta que na biblioteca de Antonio Cortesão figuravam quase todos os clássicos da língua portuguesa e também que foi ela o seu "berço de escritor". Sobre seus primeiros trabalhos, Cortesão responde que o essencial de sua personalidade de homem e de escritor está já no primeiro impresso, A Morte da Águia, poema heroico (1910), assim como na sua tese de formação em Medicina. Em Daquém e Dalém Morte, livro de contos, diz já nascer a "vocação do historiador, logo afirmada nos dramas históricos, O Infante de Sagres e Egas Moniz". Apesar de reconhece-las, diz que não as escreveria no presente.

À pergunta "O que o levou a dedicar-se ao estudo da história?" Cortesão responde, em poucas palavras: “- O desejo de alargar a consciência de cidadão português à comunidade da Nação, através dos tempos". O entrevistador emenda na resposta do entrevistado um novo questionamento, sobre qual seria o problema mais apaixonante com o qual tem se deparado em seus estudos. A resposta lança luz para a "importância das comunidades de cultura e de civilização, que excedem e dilatam os quadros estritamente nacionais e encaminham o homem para a formação dum tipo universal". Nas palavras do historiador, "a história dos povos assenta nas comunidades de cultura" e, nesse sentido, "a maior glória dos portugueses, como criadores de história, foi haver estabelecido e favorecido os contatos entre civilizações, mais do que diferentes, opostas, concorrendo como nenhum outro povo para a unificação progressiva da Humanidade". Tais afirmações, que parecem orientar o sentido para o qual se volta o olhar de Cortesão encontrava eco, como

\footnotetext{
${ }^{37}$ SANTOS, A. R. Op. cit., 1993, p. 21.
} 
veremos ao longo deste trabalho, tanto em Portugal quanto no Brasil, sustentando um pensamento recorrente que concorria para o restabelecimento da autoestima portuguesa diante de um mundo em que o nacional cedia cada vez mais espaço ao universal, também segundo o próprio Cortesão na entrevista. Todo o esforço de Cortesão era usado "para definir este sentido da história universal", sentido este que encontraria nas ações portuguesas ao longo de sua história o melhor exemplo. ${ }^{38}$

Antes de partir para a busca de vestígios que sustentem a fala de Cortesão sobre si e sobre a sua atuação, é importante examiná-la de um ponto de vista que busque identificar os traços do self-concept ${ }^{39}$ que o autor exprime, isto é, as representações e os conceitos intelectuais de si, que não raro tenderão a conferir coerência à própria história de vida. Tal operação, visível na entrevista a Jaime Cortesão citada, orienta uma vida e uma relação com o conhecimento histórico em um único sentido, o que nesse caso iria ao encontro de uma história de vida marcada pela militância política e cultural, ou seja, dedicada a um conjunto maior, expresso pelo país ou pela "comunidade de cultura" que o próprio autor menciona. Ao construir uma narrativa pública das dimensões privadas do seu trabalho intelectual notando o sentido que para ele tinham as suas produções - o autor sugere uma forma de olhar para si e para a sua obra, intimamente vinculada a questões "cívicas".

Para o historiador português Vitorino Magalhães Godinho, a história, do ponto de vista de Jaime Cortesão, servia ao objetivo de incutir nos cidadãos o sentimento de pertença e comunhão com os heróis, bem como para o planejamento e para a ação organizada. ${ }^{40}$ Como já mencionado, à exceção do livro sobre a expedição de Cabral, os textos de história passaram a ser escritos por Cortesão nas passagens por França, Espanha, Bélgica, Inglaterra. Naqueles países, o autor teve acesso a arquivos que lhe permitiram construir os trabalhos publicados entre 1930 e 1940 . Nas palavras de Joel Serrão, "no deserto do desterro, havia os oásis dos arquivos, plenos das riquezas do interesse português". Para este historiador, que considera Cortesão o "maior historiador português no período de 1925-70", aquela saudade, alimentada literariamente pela missão da Renascença Portuguesa, seria transformada pelo contexto

\footnotetext{
${ }^{38}$ CORTESÃO, J. [Entrevista a entrevistador não identificado]. Sem data/sem local. In: [Literatura e Arte, I], BNP/ACPC E25/77.

${ }^{39}$ GROSS, N. Richard Rorty's pragmatism: a case study in sociology of ideas. In: Theory and Society, v. 32, 2003.

${ }^{40}$ Godinho, V. M. Prefácio. In: CoRTesÃo, J. Os fatores democráticos na formação de Portugal. $3^{\mathrm{a}}$ ed., Lisboa: Livros Horizonte, 1974, p. 3.
} 
nacional e internacional em um "sentimento de frustração pessoal, que viria a servir, em última análise, de fermento vivificador da portentosa obra de historiador, a que se dedicaria" ${ }^{41}$ Em suma, as indicações sugerem uma relação com o conhecimento histórico profundamente calcada na intervenção cultural e política, que desde antes da partida para outros cantos da Europa e posteriormente para o Brasil, mas vivificada pela experiência do desterro, servia para sustentar a identidade coletiva de uma nação em crise e organiza-la diante do presente/futuro.

A intensa atuação cultural e política de Jaime Cortesão se inseriu em um contexto de grandes transformações da história de Portugal, vivido na virada e nos primeiros anos do século XX. Segundo Lincoln Secco, a monarquia portuguesa, em crise econômica, social e institucional foi à ruina nesse período, abrindo o caminho para o republicanismo, instaurado finalmente em 5 de outubro de 1910. A inspiração do novo regime estava em consonância com o pensamento político em voga no continente europeu, fortemente influenciado pelo socialismo utópico francês e pelo liberalismo. ${ }^{42}$

Alfredo Ribeiro dos Santos apresenta as revistas e as sociabilidades intelectuais dos "jovens da geração de Cortesão", nomeadamente seus colegas na Universidade do Porto, como experiências de uma forma "pura e idealista da doutrina libertária", especialmente à época dos primeiros periódicos Nova Silva (1907) autodeclarada "anarquista e anticlerical" e A Águia (1911) também com circulação de artistas e intelectuais anarquistas. De $A$ Águia surgiu a ideia de criar um movimento que fosse capaz de direcionar as energias para a orientação da República, surgindo assim, em 1912 a Renascença Portuguesa, tendo como fins essenciais "restituir Portugal à consciência dos seus valores espirituais próprios" e promover em todo o país uma abrangente ação cultural, cujas premissas se fundavam no Saudosismo, a partir do pensamento de Teixeira de Pascoaes. ${ }^{43}$

\footnotetext{
${ }^{41}$ SERRÃO, J. Relance sobre a vida e a obra historiográfica de Jaime Cortesão. In: Comunidades de Lingua Portuguesa, Revista Semestral de Cultura. Ed. Especial Intercâmbio Portugal-Brasil: Jaime Cortesão e o Brasil, São Paulo, n. 5, 1985, p. 48.

${ }^{42}$ SeCco, L. A Revolução dos Cravos. São Paulo: Alameda, 2004, p. 37.

${ }^{43}$ SANTOS, A. R. Op. cit., 1993, p. 25-28. A orientação "saudosista" não aconteceu sem disputas. Em uma das polêmicas sobre as definições do trabalho desenvolvido naquele movimento, Jaime Cortesão e Antonio Sérgio debateram as suas concepções sobre como relacionar-se com o passado. Enquanto Cortesão defendeu a construção de "um novo ideal coletivo" a partir de um mergulho nas "raízes do passado", viabilizado pela "renovação dos estudos históricos", Sérgio considerou "inútil procurar no passado as energias para o futuro" como também considerava exagerado delegar à história - segundo ele, estudada acriticamente - a tarefa de solucionar o presente, incorrendo no erro do "historismo", que a depreciava (SANTOS, 1993, p. 74).
} 
Na sequência, a revista Seara Nova acabou se tornando um importante instrumento político, cultural e social do grupo que acabou por se encontrar empregado na Biblioteca Nacional de Portugal. No gabinete de Cortesão, diretor da instituição, Câmara Reys, Raul Brandão, Raul Proença, Aquilino Ribeiro e Ferreira Macedo idealizaram o projeto, que em outubro de 1921 teve o seu primeiro número publicado.

Em seu primeiro ciclo, até 1926, a revista foi pautada pela "definição doutrinária, crítica sistemática aos 'males da República', intervenção política pontual e denúncia do perigo fascista". Censurada durante alguns meses entre 1926 e 1927, a Seara viveu um segundo ciclo até o ano de 1939, marcado pela oposição à ditadura vigente, quando muitos dos seareiros estavam exilados, entre eles Cortesão, por ter participado de um levante em fevereiro de 1927. Nesse período, foi marcante a atuação de Antônio Sérgio, que se afastou em 1939 por divergir da gestão de Câmara Reys. De 1939 a 1958, o terceiro ciclo é caracterizado como de "resistência cívica", dominada pelo discurso reivindicatório das liberdades, de acordo com a linha republicana tradicional. Depois do período de crises financeiras e irregularidade na circulação, as correntes marxistas e as novas gerações renovaram a doutrina da publicação no período que se estende de 1959 a 1974, quando a Seara Nova se expandiu significativamente. Outrora "um foco de resistência intelectual ao Estado Novo", a Revista persiste na atualidade. ${ }^{44}$

Instrumentalizando ideais e projetos comuns de um grupo de intelectuais de orientações republicana, socialista, democrática, a Seara Nova e suas propostas de intervenção política e cultural têm grande importância do outro lado do Atlântico, para onde emigram - por escolha, por contingência ou por imposição - muitos dos seareiros. Quando Cortesão menciona um "programa de ação" durante o período de expatriação vivido por ele e, a partir de seu ponto de vista, partilhável por todo e qualquer português estabelecido no Brasil, não podemos perder de vista a grande relevância que espaços de sociabilidade como a Seara Nova representam nesse sentido, fomentando o florescimento e a circulação de ideias e projetos. ${ }^{45}$

44 SAntos, A. R., Op. cit., 1993, p. 131; "História", seção disponível em <http://www.searanova.publ.pt/pt/static/menu/97/História.htm>. Acesso em 12 jun. 2015. A Seara Nova conta 1731 edições até junho de 2015, tendo comemorado seus noventa anos em 2011.

${ }^{45}$ Refiro-me a CoRTESÃo, J. Jaime Cortesão [Entrevistador não identificado] 10 abr. 1958. Diário de Notícias. Palavras no tempo, v. 2 - Cultura. Lisboa: Imprensa Nacional/Casa da Moeda, 1991, p. 61. 
Mário Soares (1924-), então presidente da República (1986-1996) quando escreveu o prefácio da biografia de Cortesão por Alfredo Ribeiro dos Santos, disse que Cortesão tinha sido um reformador de Portugal durante o período ditatorial. $\mathrm{O}$ intelectual, como toda a geração dos seareiros, apresentou grande preocupação com a reforma da nação de modo concreto. Para Soares, o grupo levantou problemas e carências do país e propôs uma renovação e formação das elites morais, científicas e intelectuais portuguesas. O contexto da criação da revista era de inconsistência e descrença na classe política, sem objetivos bem definidos frente às consequências negativas, sobretudo na economia, após a participação na Grande Guerra. Ainda segundo Soares, Cortesão possuía uma "ideia para Portugal, feita no estudo da terra, da gente, e do seu passado multissecular" e essa ideia "quis implantar e desenvolver, com carinho e persistência". ${ }^{46}$ Nas palavras do ex-presidente, nota-se a relevância de uma personalidade por assim dizer heroica de Cortesão, com quem Mário Soares teve algum contato na juventude.

Durante a etapa francesa de seu exílio, Cortesão esteve próximo das inovações no campo da historiografia, área da qual se tornava íntimo ao mesmo tempo em que dava prosseguimento às suas atividades políticas de oposição ao governo que tinha tomado o poder em Portugal. Fora de Portugal, mantinha os laços com a Seara, que apesar de sofrer os impactos da reorganização do círculo social e das pressões por parte do regime instaurado, mantinha modestamente as suas publicações. A pesquisa histórica nos arquivos franceses, belgas, espanhóis e ingleses e a publicação de textos na imprensa ou em reuniões acadêmicas era a principal, quando não a única possibilidade de manter-se em contato com a sua pátria.

Cortesão, em texto de 1929 remetido a um jornal e incompleto, diz não ter se arrependido da revolta da qual tomou parte em 1927, razão de sua demissão da Biblioteca Nacional, e fala da tirania que estava no poder em Portugal. Criticou os partidos portugueses, que estavam preocupados apenas consigo próprios, não colaborando com a democracia no país e não fazendo jus ao Estado que já esteve entre a "elite da humanidade". Cortesão fala do "Portugal dos Descobrimentos", com o qual vive então:

Tenho aproveitado o meu exílio em trabalhar na minha obra sobre os Descobrimentos dos portugueses. As minhas investigações no estrangeiro dilataram muito o meu horizonte sobre este capítulo da História, que creio

\footnotetext{
${ }^{46}$ SoARes, M. Prefácio. In: SANTOS, A. R., Op. cit., 1993, p. 11.
} 
poder reescrever em bases novas. Esse labor mitiga as saudades que tenho de Portugal. Vivo e trabalho constantemente dentro duma Pátria ideal, da qual estão bem mais exilados a maioria dos meus compatriotas que vivem em terra portuguesa. ${ }^{47}$

Sem desprezar a dimensão da imagem que o escritor busca apresentar de si, fortemente marcada pela demonstração de compromisso com o país ainda que fora dele, o pequeno texto, escrito provavelmente em Paris pouco mais de dois anos após a sua participação num movimento contra o golpe perpetrado em 1926, lança uma dura crítica tanto à "tirania" que estava no poder quanto aos partidos políticos locais que pouco se empenhavam para fazer valer a democracia no país.

A impossibilidade de verificar se o artigo foi ou não concluído e publicado restringe as perspectivas de análise, que, no entanto, não deixam de ser profícuas, considerando o conteúdo do escrito. Ao criticar a elite política que não faz jus ao passado português, Cortesão se volta para o "Portugal dos Descobrimentos", com o qual se envolve na vida de exilado, tudo dito em um tom que demonstra total descrença em relação ao presente: a imagem que faz, considerando exilados os seus compatriotas que não saíram do país e que vivem sob um regime de exceção, expressa o sentido do trabalho com o Portugal do passado, uma nação ideal. Dessa forma, as saudades da terra do presente são superadas pelo contato com os vestígios de um tempo não vivido.

Alguns documentos sugerem o que seriam as tais "bases novas" sobre as quais pretendia reescrever a história sobre os descobrimentos portugueses. Cortesão participou de uma reunião na Biblioteca Nacional da França com especialistas franceses e estrangeiros para debater um problema de cartografia quinhentista. Sob a presidência de Charles de la Roncière (1870-1941), historiador da geografia e diretor de seção na instituição francesa, a sessão também teve como integrantes Albert Kraemmer, ex-embaixador da França no Brasil; Georges Le Gentil (1875-1953), professor de língua e literatura portuguesa e brasileira na Sorbonne; Marcel Destombes (1905-1983), cartógrafo; os portugueses Duarte Leite e Fontoura da Costa, mestres em história da geografia, entre outros. $\mathrm{O}$ assunto debatido foi um mapa que desde 1897 se encontrava na biblioteca parisiense, conhecido por Atlas Miller, nome de seu último proprietário, que o recebeu pelas mãos do Visconde de

\footnotetext{
${ }^{47}$ CORTESÃO, J. [Sem título]. [Paris?], 27 abr. 1929. Texto incompleto enviado para publicação. $1 \mathrm{fl}$. $\mathrm{BNP} / \mathrm{ACPC} \mathrm{E} 25 / 20$.
} 
Santarém. As cartas abrangem Europa, Ásia e América então conhecidas e parte da África com o Índico ocidental. O documento contém parte do litoral sul-americano identificado com 142 nomes, excedendo assim todas as cartas quinhentistas. Representam-se índios ocupados na colheita e no transporte de pau-brasil.

Destombes confirmou a autenticidade da Carta como sendo de Lopo Homem, cosmógrafo real. No texto escrito por Cortesão como relato da reunião, provavelmente enviado para publicação em Portugal, o autor qualifica a Carta como sendo "a mais bela carta quinhentista do Brasil", na ocasião com a autoria e a data finalmente precisadas. De 1519, a Carta de Lopo Homem declara expressamente que a sua feitura foi por mando de D. Manuel, tratando-se assim de uma figuração oficial, de abundante nomenclatura e com duas bandeiras portuguesas assinaladas, uma a norte da foz do Amazonas e outra a sul do Prata, o que de seu ponto de vista significaria "uma intenção reivindicatória, desde sempre em clara oposição aos ditames do Tratado de Tordesilhas, mas imposta pela geografia e perseguida através de três séculos com incrível tenacidade e heroísmo". ${ }^{48}$ Como acompanharemos ao longo deste trabalho, a cartografia e as questões de limites, tratados e reinvindicações territoriais serão a espinha dorsal da escrita histórica de Cortesão no Brasil.

Além disso, em seus apontamentos e reflexões, encontram-se não apenas notas escritas sobre o método da pesquisa histórica segundo Langlois e Seignobos como também reflexões a partir de Camille Vallaux, geógrafo, de quem anota a ideia "O Atlântico é por excelência um Oceano humanizado". ${ }^{49}$ No período em que Cortesão esteve em Paris, o lançamento da revista Annales, por Marc Bloch e Lucien Febvre em 1929, lançava outras bases para a produção do conhecimento histórico, em interlocução especialmente com as outras ciências humanas e sociais. O ambiente intelectual em que viveu, portanto, não passava ao largo dos novos olhares que se lançavam para a escrita histórica.

\section{Sensibilidades, sociabilidades e condições de produção e disseminação}

\footnotetext{
${ }^{48}$ CORTeSÃo, J. Cartas de Paris, II: autoria e data da mais bela carta quinhentista do Brasil. $7 \mathrm{f}$. $\mathrm{BNP} / \mathrm{ACPC} \mathrm{E} 25 / 34$.

${ }^{49}$ CORTESÃO, J. [História, II]. BNP/ACPC E25/81.
} 
No prazo de pouco mais de um mês desde a sua chegada, amparado pelas indicações de seus patrícios e pela acolhida que lhe deram portugueses que viviam no Brasil e brasileiros, Jaime Cortesão obtinha recursos financeiros a partir de seus trabalhos, como as conferências que proferiu no Rio de Janeiro e em São Paulo. Tornou-se também secretário do Gabinete Português de Leitura, biblioteca lusobrasileira, criada após a independência do Brasil na então capital do país. Aquilino Ribeiro, ex-integrante do "Grupo da Biblioteca" e seareiro, dissera ter situado Jaime Cortesão no meio político e literário brasileiro "com rigor psicológico e exata proporção". Ao mencionar a sua integração no país, Ribeiro diz ter verificado que o amigo "gozava fama e crédito correlativo de grande e nobre português". ${ }^{50}$ Sarmento Pimentel, que também esteve ao lado de Cortesão na criação da Seara Nova, vivia no Brasil desde a sua demissão na Biblioteca Nacional portuguesa. Ao falar sobre os seus compatriotas emigrados políticos no Brasil, sobretudo sobre Jaime Cortesão, desmentiu os jornais que tentam associá-los a seus cargos no governo como fontes de grandes fortunas. Descreveu uma experiência árdua e de recursos escassos, aproximando-se do drama, afirmando que muitos dos exilados se contentavam com o trabalho que aparecesse, independente de qual fosse. ${ }^{51}$ Pimentel, radicado em São Paulo, teve um papel fundamental na relação de Cortesão às redes paulistanas.

Duas casas editoras cariocas publicaram obras do intelectual português, a Dois Mundos e a Livros de Portugal. Ambas, como o próprio nome escolhido sugere, eram especializadas na edição de textos portugueses, então disponibilizados no mercado editorial local. Tais espaços foram cruciais para a visibilidade de Cortesão e de outros escritores portugueses, representando também fontes de renda para essas pessoas que construíam sua vida em outro país. A dimensão das editoras especializadas como espaço de sociabilidade também não pode ser perdida de vista, como tratarei adiante, observando especialmente a relação entre editores e intelectuais.

Para compor o quadro das relações estabelecidas no processo de integração de Cortesão e de outros intelectuais emigrados - o que foi bastante corrente no período na Segunda Guerra Mundial (1939-1945), os trabalhos sobre biografias intelectuais, individuais ou coletivas, ajudam a delinear algumas direções possíveis

\footnotetext{
${ }^{50}$ RibeIRo, A. Reencontro com Jaime Cortesão. In: Seara Nova, Lisboa, número de homenagem a Jaime Cortesão, n. 1266-69, 27 dez. 1952, p. 187.

${ }^{51}$ Pimentel, J. S. Portugueses emigrados políticos no Brasil. In: Seara Nova, Lisboa, número de homenagem a Jaime Cortesão, n; 1266-69, 27 dez. 1952, p. 196.
} 
de análise. Nesse sentido, o estudo de Fernanda Arêas Peixoto (2010) a respeito das experiências no Brasil de Roger Bastide e Pierre Verger, ajuda a iluminar o que se denomina como solidariedades intelectuais entre compatriotas emigrados para um mesmo país: os passos trilhados e as experiências vividas por um que chegou antes frequentemente servem para orientar e servir de feedback para o outro que chegou depois.

Laurent Jeanpierre (2004), ao discutir e comparar os casos de Claude LéviStrauss e Georges Gurvitch nos Estados Unidos, retoma ideias presentes em Paul Hoch (1987) para pensar nos privilégios epistemológicos de um exilado, apropriando-se do raciocínio de Simmel. O autor defende que um intelectual que circula entre diferentes espaços institucionais, seja dentro de um mesmo país ou entre países diferentes, temporária ou permanentemente, dispõe de condições e de ferramentas que podem favorecer a inovação, considerando o contato com ideias e práticas distintas, eventualmente mobilizadas pelo sujeito em sua prática. É preciso levar em conta não só o campo intelectual de origem do sujeito em questão, como também percebê-lo a partir de todos os meandros do campo de destino. Jeanpierre põe em destaque o que chama de "investimentos sociais" de indivíduos emigrados, investimentos estes que possuem seus riscos, frequentemente correspondentes às possibilidades de êxito. Essa abordagem serve de ponto de partida para trazer à tona algumas questões que podem ser feitas ao processo de integração e de visibilidade/reconhecimento de Jaime Cortesão no Brasil.

Ressalvas são necessárias para com a categoria "exilado", que embora possa expressar a condição de um sujeito banido oficialmente de seu país, não explica satisfatoriamente a complexidade que esta condição pode representar. A carga semântica que a palavra carrega consigo supõe suspensão, alheamento, ausência de raízes e de vínculos, tanto em relação ao lugar que ficou para trás quanto em relação ao processo por vezes doloroso de criar vínculos com um novo território. Ademais, a condição de exilado pode sugerir uma perenidade da separação entre o sujeito e o seu lugar, o que não raro pode ser percebido nas palavras de qualquer sujeito que passe pela experiência de ansiar pelo retorno, viável ou não, visível no horizonte ou desesperadoramente distante.

Todas essas possibilidades devem ser postas em questão quando se observa a trajetória de Cortesão entre o momento em que sai de Portugal por conta própria, motivado pelas pressões que antecederam e se sucederam à sua demissão da 
Biblioteca Nacional de Portugal, em 1927; a ocasião em que é preso e banido, partindo para o Brasil, em 1940; e a missão que realiza em 1953/1954, em Lisboa e em outros cantos da Europa, em nome da comissão organizadora das comemorações do quarto centenário da fundação de São Paulo. Entre idas e vindas à sua terra, durante o interregno que se estende de 1940 a 1957, quando para lá retorna definitivamente, são visíveis os vestígios da aproximação com o Brasil e da sensação de acolhimento, da saudade de Portugal, dos possíveis mal-entendidos relativos à nacionalidade quando de seu envolvimento em questões brasileiras. Por outro lado, a dimensão das sensibilidades do autor nesse sentido não pode ser lida desinteressadamente, uma vez que toda declaração, especialmente pública, demonstra uma representação de si, uma elaboração sobre o vivido que constrói uma narrativa da experiência que justifica escolhas, decisões, percursos.

A própria opção pelo Brasil, eleito como destino por assim dizer definitivo, considerando que poucas esperanças de retorno ao país natal eram oferecidas em um contexto de regime de exceção e de estado de guerra, é eivada de simbolismos, como no trecho de uma entrevista concedida em 1958, em resposta à indagação de qual teria sido a lição de sua larga estada no Brasil:

(...) [A] minha ida para o Brasil, em 1940, realizou-se sob o imperativo de circunstâncias alheias à minha vontade. A expatriação é sempre dolorosa. Mas nenhum país pode para um português substituir a sua pátria, a não ser o Brasil. Depois, viver no Brasil é conhecer, sob certos aspectos, um Portugal mais português que o da metrópole; um Portugal que foi sonhado e medido pelas dimensões de um continente e transplantado com a totalidade da seiva originária para uma terra, um clima e um meio humano que representavam outros tantos e terríveis problemas de adaptação a resolver. Não é pequena lição e proveito para um português haver compreendido este fato e transformá-lo em programa de ação. ${ }^{52}$

No momento em que Cortesão partiu de Portugal pela primeira vez, não saiu do continente europeu. Àquela altura, o escritor ainda não estava na lista dos obrigados a deixar o país e mantinha-se ativo na atuação política voltada para a realidade portuguesa. Outros seareiros e intelectuais portugueses, como Sarmento Pimentel, muito próximo de Cortesão, já tinham optado pelo Brasil como residência desde então. Jaime Cortesão somente embarcou rumo ao Rio de Janeiro por força das circunstâncias, como vimos, quando foi preso e banido de seu país. Encadeadas,

\footnotetext{
${ }^{52}$ CORTESÃo, J. [Entrevista a] Jaime Cortesão. Entrevistador não identificado. Lisboa, 10 abr. 1958. In: DiÁRIO DE NOTíCIAS. Palavras no tempo, vol. 2 - Cultura. Lisboa: Imprensa Nacional/Casa da Moeda, 1991, p. 61.
} 
duas frases exprimem a forma como o intelectual quis sintetizar a sua experiência brasileira: na primeira consagra o Brasil como o único país capaz de substituir Portugal para um português e, em seguida, diz considerar a vivência no Brasil como capaz de proporcionar o contato com um "Portugal mais português que o da metrópole". Ao expressar com essas imagens o processo de migração e de enraizamento em outra terra, o escritor possibilita a visualização de um paralelo com a ideia que segue em sua réplica, a de um Portugal que permanece na ex-colônia por meio de características "transplantadas" e aclimatadas não sem "terríveis problemas de adaptação a resolver". Seguindo o raciocínio de sua construção, a compreensão do sentido da colonização é uma grande e proveitosa lição que um português dos novecentos deveria transformar em "programa de ação". Com a resposta, Cortesão narra o seu processo de "transplante" dando sentido às suas ações no Brasil, iluminado por uma compreensão da história da colonização portuguesa.

Seguindo por essa trilha, Cortesão pode ser visto como um sujeito em integração ao campo intelectual de destino, na medida em que atuam sobre esse momento de sua vida experiências já vividas por outros emigrados portugueses, circulações entre instituições congêneres dos dois países e o seu grau de envolvimento em debates relevantes do contexto político e cultural brasileiro, a despeito de eventuais dificuldades, críticas e momentos de tensão com sujeitos ou grupos nacionais. Além disso, como citado, condições institucionais e materiais viabilizam esse processo. Os capitais simbólicos, culturais e sociais do autor, dentro desse conjunto, permitem a ele a ampliação das possibilidades que estariam ao alcance de qualquer outro emigrado. Isso pode ser avaliado levando em conta a representatividade e o protagonismo do qual Cortesão desfrutava para grande parte da comunidade de intelectuais portugueses residente no Brasil.

Acompanhando a sua atuação para além dos círculos institucionais, o das Academias, Associações e outros espaços formados por grupos restritos, nota-se uma sólida presença de Cortesão na imprensa brasileira, inicialmente na carioca: Diário de Notícias, Jornal do Commercio e quase majoritariamente n'A Manhã, periódico portavoz do regime do Estado Novo, chefiado pelo modernista "verde-amarelo" Cassiano Ricardo ${ }^{53}$; e depois na paulistana (n'A Gazeta de Cásper Líbero e majoritariamente

\footnotetext{
${ }^{53} \mathrm{Um}$ estudo detalhado sobre este periódico e seus suplementos, a partir da perspectiva da política cultural e da cultura histórica do Estado Novo foi feito por GOMES (1999).
} 
n'O Estado de S. Paulo, da família de Júlio de Mesquita Filho, que congregava diversos colaboradores portugueses emigrados e que se opunha ao regime de Vargas. A sua atividade nesses espaços vai ao encontro do que propõe Sirinelli (2003): sugere afinidades, sociabilidades, ideias em circulação, que por sua vez também podem indicar outros caminhos para compreender as dinâmicas de seu pensamento e de sua atuação no país, para além da representação que ele próprio forjou a respeito de seu "programa de ação".

O diário matutino A Manhã começou a circular em agosto de 1941 e a sua posição doutrinária, de "caráter didático na exposição das ideias do presidente e dos feitos do regime" ${ }^{\prime 4}$, o tornava porta-voz do Estado Novo, fazendo frente a uma imprensa nada simpática ou favorável a Vargas. Pode-se considerar que esse foi um dos espaços de aproximação com o programa cultural do regime autoritário que se estendeu de 1937 a 1945. Cassiano Ricardo, responsável pelo periódico, era um dos muitos intelectuais chamados à ação política, segundo a abordagem de Mônica Velloso (2003) e que será aprofundada adiante. Em linhas gerais, aquela política cultural construía as bases de uma identidade nacional hegemônica, harmoniosa e pacífica, dentro de um país uno que se relacionava diretamente com a figura paterna daquele presidente. ${ }^{55}$

O periódico não só publicava textos de Cortesão, que apareceram a partir de 1942, como divulgava atividades do intelectual, como palestras, conferências, lançamentos, eventos organizados por ele. Em novembro de 1941, o jornal noticiava a confecção do catálogo da Exposição e Quinzena do Livro Português, "obra de alto interesse para bibliófilos", a ser lançado na Biblioteca Nacional. ${ }^{56}$ Além de mencionar realizações de Cortesão em nome da diretoria do Gabinete Português de Leitura, reporta-se a inauguração da editora Livros de Portugal, sob direção intelectual de Jaime Cortesão. Naquela ocasião, o escritor ressaltou a importância daquela iniciativa para a "cordialidade luso-brasileira". Em nome dos escritores brasileiros,

\footnotetext{
${ }^{54}$ Gomes, A. C. História e Historiadores: a política cultural do Estado Novo. Rio de Janeiro: Ed. FGV, 1999, p. $15-16$.

${ }^{55}$ Ideias centrais construídas, fomentadas, difundidas pelo Estado Novo, especialmente aquelas que dizem respeito ao caráter pacífico, laborioso mestiço, dentre outras adjetivações, serão tratados ao longo de todo o texto, a partir da apreciação da narrativa histórica construída sobre Brasil àquela época, versão esta capaz de corporificar e legitimar sensos comuns a respeito das relações historicamente construídas e eliminar quaisquer traços dos conflitos presentes na sociedade brasileira. ${ }^{56}$ In: A Manhã, Rio de Janeiro, 2 nov. 1941, p. 11.
} 
Pedro Calmon agradeceu a Souza Pinto e a Freitas Bastos, os editores, a oportunidade que se abria de entendimento intelectual entre ambos os países. ${ }^{57}$

Nas páginas d'A Manhã muitas ocasiões da trajetória de Jaime Cortesão no Rio de Janeiro evidenciam a sua plena integração e os momentos em que aparece na cena pública carioca, especialmente em ocasiões relativas à cultura portuguesa. Um mês após a inauguração da editora Livros de Portugal, teve lugar na Capital Federal, na sede da Associação Brasileira de Imprensa (ABI) uma solenidade em homenagem ao centenário de Antero de Quental. A sessão foi promovida pelo Departamento de Imprensa e Propaganda do Governo Federal, órgão-chave do regime estadonovista e pelo Secretariado da Propaganda de Portugal, representados na ocasião pelo diretor do órgão brasileiro, Lourival Fontes e pelo embaixador de Portugal, Martinho Nobre de Melo. Herbert Moses, presidente da ABI, Manuel Bandeira, Jaime Cortesão, entre outros, compunham a mesa do evento, sendo que estes dois escritores falaram sobre a obra e a vida do homenageado. ${ }^{58}$ A íntegra da fala de Cortesão no evento foi publicada dias depois nas páginas do periódico. Na celebração de outro centenário, o de Eça de Queiroz, comemorado no fim do ano de 1945, Cortesão proferiu uma conferência, na sede da mesma Associação, intitulada "Eça de Queiroz e a questão social", que é também o título de uma de suas obras. Além dos mesmos integrantes do evento que havia festejado Antero de Quental dois anos antes, Murilo Mendes também marcou presença. ${ }^{59}$

O matutino do aparato varguista não era livre de tensões internas. A partir de 1943, a situação política no interior do jornal se alterou, especialmente depois do Manifesto dos Mineiros, documento em que se pedia o restabelecimento da democracia, a revelar os conflitos que presidiam "a delicada convivência entre intelectuais e setores da burocracia estadonovista". A partir daquele momento, personalidades como Afonso Arinos de Melo Franco e Manuel Bandeira se afastaram do jornal, que conviveu dali em diante com a aceleração da abertura do regime até a sua dissolução no início de 1945. Segundo a historiadora Ângela de Castro Gomes, $A$ Manhã experimentou uma sobrevida entre o fim do regime e o seu completo desaparecimento em $1953 .^{60}$

\footnotetext{
${ }^{57}$ In: A Manhã, Rio de Janeiro, 19 mar. 1942, p. 8.

${ }^{58}$ In: $A$ Manhã, Rio de Janeiro, 19 abr. 1942, p. 3.

${ }^{59}$ In: A Manhã, Rio de Janeiro, 23 dez. 1945, p. 3.

${ }^{60}$ GOMES, A. M. C. Op. cit., 1999, p. 28-29.
} 
Se quase a totalidade da imprensa não era simpática a Vargas, cabe destacar o caso emblemático do jornal $O$ Estado de $S$. Paulo, então sob a direção de Júlio de Mesquita Filho. Emblemático porque, no que diz respeito a este trabalho, o diário, além de fazer oposição ao governante que representava o fim do domínio das oligarquias mineira e paulista, congregava diversos exilados portugueses e era um significativo espaço de sociabilidade intelectual, responsável por diversas iniciativas daquela mesma oligarquia, agora investindo em outras áreas. De acordo com Nanci Leonzo, Júlio de Mesquita Filho foi um antissalazarista que fez de tudo para

auxiliar os intelectuais aqui exilados, mesmo aqueles cujas concepções políticas e ideológicas entravam em choque com seu ardente liberalismo (...). Para Mesquita Filho, Portugal vivia, no início dos anos [19]50, uma ditadura moldada "pelo temperamento e tendências personalíssimas do seu criador". Lá, completou, o fascismo se revelara como "um processo de esterilização pessoal". Cabia-lhe, pois, colaborar para manter vivo, pelo menos no Brasil, o espírito criativo português. ${ }^{61}$

Segundo Miceli, o jornal dos Mesquita marcou a hegemonia paulista no campo intelectual brasileiro por meio da Revista do Brasil, criada em 1916, e que prestigiava aqueles que pudessem nela ter os seus textos. ${ }^{62}$ Além disso, esses mesmos grupos fomentaram projetos que seriam respostas às derrotas de 1930 e 1932: de seu ponto de vista, a origem dos problemas que a levaram ao fracasso não estava na falta de canais de expressão e participação social ou de respostas adequadas às diversas demandas da sociedade, mas sim na ausência de quadros técnicos, políticos e culturais pertinentes ao contexto. Por esse motivo, investiram na criação de instituições que se tornaram "inesperados instrumentos de luta: a Escola de Sociologia e Política, a Faculdade de Filosofia, Ciências e Letras, no contexto da nova Universidade de São Paulo, e o Departamento Municipal de Cultura" ${ }^{63}$

Conforme o levantamento bibliográfico feito por Neves Águas (1985), Cortesão publicou apenas dois artigos no Jornal do Commercio em 1941 e a partir do ano seguinte escreveu uma série de artigos n'A Manhã, sobre a "vida e obra" de Alexandre de Gusmão, que logo figuraria em seus cursos junto ao Ministério das Relações Exteriores e na organização da documentação da Coleção De Angelis na Biblioteca Nacional. Concluída a série, só retorna a escrever para o jornal em 1946,

\footnotetext{
${ }^{61}$ LeOnzo, N. Jaime Cortesão: um condestável em terras brasileiras. In: Revista da Cátedra Jaime Cortesão, São Paulo, v. 1, n. 1, 1997, p. 37.

${ }^{62}$ MiCELI, S. Op. cit., 2001, p. 90-91.

${ }^{63}$ MiCELI, S. Op. cit., 2001, p. 101.
} 
após o fim do Estado Novo, e publica quase semanalmente até julho de 1947. N'O Estado de S. Paulo o primeiro texto saiu em $1943^{64}$, dedicado à figura de João Ramalho e nele seguiu ativo até o seu retorno para Portugal, com textos regulares especialmente a partir de 1947. Com participação mais evidente nos dois últimos periódicos destacados, Cortesão também teve seus textos nos cariocas Diário de Notícias, O Jornal, Diário Carioca e na revista Diretrizes, assim como nos paulistanos Correio Paulistano, A Gazeta e na revista Anhembi. Alguns dos artigos foram publicados tanto n'O Estado quanto n'A Manhã, assim como em jornais de Angola, de Moçambique ou de Portugal. Cortesão também publicou artigos em revistas acadêmicas, como na Revista de História, da Faculdade de Filosofia, Ciências e Letras da Universidade de São Paulo. ${ }^{65}$ Os textos publicados na imprensa se referiam especialmente às suas pesquisas em andamento e eventualmente a trabalhos realizados ainda em Portugal/na Europa. Destaca-se um conjunto de 227 artigos, de 1943 a 1960, levantados por um dos editorialistas d'O Estado, João Alves das Neves (1985): desses, 64 foram reunidos e publicados postumamente em Portugal, sob o título Introdução à História das Bandeiras, em dois volumes.

A partir desse quadro é possível visualizar parte da movimentação de Cortesão logo após chegar ao Brasil, notando especialmente as redes de sociabilidade intelectual articuladas pelo exílio, que congregava portugueses em ambientes comuns, assim como as especificidades do caso de Cortesão: o ex-diretor da Biblioteca Nacional de Portugal, membro da Academia de Ciências de Lisboa (atributo que é

\footnotetext{
${ }^{64}$ De 25 de março de 1940 a 6 de dezembro de 1945, o jornal O Estado de S. Paulo esteve sob intervenção do Estado Novo, após ser acusado de conspirar contra Vargas. Segundo o Acervo Estadão, "esse período não entra na história do jornal", conferindo às edições sob intervenção apenas valor como documento histórico. Disponível em: <http://acervo.estadao.com.br/historia-dogrupo/decada_1940.shtm>. Acesso em 24 jun. 2015.

${ }^{65}$ Jaime Cortesão figurou nas páginas da Revista de História da Universidade de São Paulo em 1950, em um de seus primeiros números (n. 4, out.-dez. 1950). Na ocasião, foi publicada a sua conferência sobre Alexandre de Gusmão e o Tratado de Madri, proferida no Itamaraty em setembro de 1949. Na mesma edição figuraram textos de Myriam Ellis, Fidelino de Figueiredo e Alice Canabrava. No número 17, saído no primeiro trimestre de 1954, período em que se comemorava o aniversário da fundação da cidade de São Paulo, o autor teve publicado O território da Colônia do Sacramento e a formação dos estados platinos, que dividiu as páginas do volume com um artigo sobre $A$ fundação de São Paulo pelos jesuitas, do Pe. Hélio Abranches Viotti, S.J. e A segunda fundação de São Paulo: da pequena cidade à grande metrópole de hoje, de autoria do Professor Eurípedes Simões de Paula, da própria Universidade. Thomaz Oscar Marcondes de Souza, grande colaborador da Exposição de História de São Paulo, assinou um texto quando do falecimento de Cortesão (n. 44, out.-dez. 1960). Também em sua homenagem, a edição seguinte (n. 45, jan.-mar. 1961) publicou a conferência inédita $A$ maior bandeira do maior bandeirante, proferida no Salão Nobre da Faculdade de Filosofia, Ciências e Letras da Universidade de São Paulo. Tais vestígios apontam para os vínculos entre Cortesão, a Universidade e alguns dos seus professores.
} 
destacado no cabeçalho da edição da Carta de Pero Vaz de Caminha), acompanhado da recomendação de intelectuais portugueses a Afrânio Peixoto e Pedro Calmon, responsáveis pela sua acolhida na Academia Brasileira de Letras. Cortesão foi tratado com deferência, a partir dos seus capitais simbólicos; no entanto, o destaque que alcançou no Brasil se deveu especialmente ao trabalho desempenhado em duas instituições: a Biblioteca Nacional e o Ministério das Relações Exteriores/Instituto Rio Branco, que estão, em muitos casos, na origem dos textos publicados na imprensa.

Na primeira iniciativa editorial de Cortesão no Brasil, a Coleção Clássicos e Contemporâneos, o editor Antonio Augusto de Sousa Pinto teve a ideia de lançar o projeto e pedir a Cortesão que o organizasse e dirigisse. Segundo o historiador, ele e o editor tinham em comum a impressão de que o público brasileiro tinha perdido o gosto pelas obras primas da literatura portuguesa e de que era preciso renová-lo. Além disso, era preciso "responder aos apelos de alguns dos mais eminentes espíritos brasileiros e portugueses residentes no Brasil, que, pessoalmente, ao editor e ao escritor proclamaram os perigos que ameaçavam a cultura luso-brasileira". Para destacar essas vozes que falam da "ameaça" à cultura luso-brasileira, Cortesão cita Gilberto Freyre e uma "eloquentíssima" conferência pública, àquela altura já impressa pela Casa do Estudante Brasileiro. Aos leitores portugueses que se encontram em seu país, Cortesão exorta a leitura desse "aviso", para que fiquem cientes dos perigos que tornam a tal ameaça "densa e vasta" ${ }^{66}$

O projeto da Coleção teve por objetivo trazer à publicidade textos remotos e recentes, escritos nas mais diversas áreas, incluído escritos como os Sermões de Santo Antônio de Lisboa "exemplo da vocação franciscanista e precursor, no século XIII, do universalismo dos portugueses": e esse humanismo universalista/franciscano é uma das teses defendidas por Cortesão, como base da formação portuguesa e de suas ações ao longo de sua história. Além disso, seriam apresentados textos da literatura de viagem, considerados pelo diretor como importantes contributos "para a história da geografia, a história natural em todas as partes do mundo e (...) da etnografia, no sentido mais amplo da palavra, das raças mais variadas". ${ }^{67}$

\footnotetext{
${ }^{66}$ Cortesão, J. A Carta de Pero Vaz de Caminha. Rio de Janeiro: Livros de Portugal, 1943, p. I. Coleção Clássicos e Contemporâneos, v. 1).

${ }^{67}$ CORTESÃO, J. Op. cit., 1943, p. II.
} 
Apesar dos custos que implicaria a publicação da Coleção, Cortesão diz que Antonio Pinto cumpria assim com os "deveres morais de editor português no Brasil", uma vez que ele tinha aceito o plano proposto pelo historiador ciente da possibilidade de fracasso comercial. O que estava em questão não era primordialmente, a partir do que se pode inferir, o retorno financeiro do projeto, mas o seu propósito de recuperar o prestígio ameaçado da cultura portuguesa (chamada de luso-brasileira), ou ao menos o revés financeiro seria compensado pela consciência de ter dado a sua contribuição pela causa considerada justa. Isso não exclui, no entanto, a possibilidade de essa ser uma forma de construir uma imagem de desprendimento e de compromisso incondicional com a causa da cultura portuguesa no Brasil, no mesmo sentido do seu "programa de ação".

O número de estreia da referida coleção foi a edição da Carta de Pero Vaz de Caminha, publicada em 1943, no volume em que são apresentadas as diretrizes da série. Outro título que veio a lume foi Diálogos das Grandezas do Brasil, outro documento do interesse dos primeiros tempos da colonização portuguesa em terras sul-americanas. Pela primeira vez o texto figurava com o nome de seu autor, Ambrósio Fernandes Brandão. Na ocasião, o exemplar seguiu a linha inicialmente proposta, de publicar textos portugueses apresentados por escritores brasileiros: $\mathrm{o}$ historiador Capistrano de Abreu fez a introdução de Diálogos. ${ }^{68}$ Cortesão ofereceu exemplares do primeiro número de sua empreitada editorial a pessoas de seu círculo, entre eles Afrânio Peixoto, que lhe responde muito elogiosamente e lisonjeado pela dedicatória e pelas tantas citações ao longo do texto com o qual apresentou e introduziu o volume inaugural. Peixoto caracteriza o prefácio de Cortesão como "sábio e onisciente", a preparar o leitor para o contato com um "belo livro que deu às nossas Letras". ${ }^{69}$

$\mathrm{Na}$ correspondência que dirige a Câmara Reys, o amigo de longa data e seareiro, Cortesão permite observar que sua chegada era esperada e anunciada pelos jornais cariocas e que de Portugal acompanhavam-lhe recomendações a figuras

\footnotetext{
${ }^{68}$ In: O Estado de S. Paulo, São Paulo, 3 mar. 1944, p. 4.

${ }^{69}$ Peixoto, A. Correspondência a Jaime Cortesão. Rio de Janeiro, 20 set. 1942. Pela data da correspondência, pode-se afirmar que Afrânio Peixoto recebeu o seu exemplar da Carta de Pero Vaz de Caminha ainda antes de sua comercialização. Chamado de "caro e ilustre amigo" na abertura da correspondência, o remetente se despede chamando-se "devoto" do destinatário, na carta que vem com o timbre da Academia Brasileira de Letras. BNP/ACPC E25/733.
} 
destacadas de instituições de relevo no Brasil, apresentando assim alguns indicadores da circulação intelectual luso-brasileira:

Rogo-lhe o favor de anunciar (...) ao Hernâni [Cidade], que falei com o Afrânio [Peixoto] (amicíssimo!) que me disse que o seu capítulo segue pelo Angola e breve a colaboração dos demais; ao Dr. R.[Rodrigues] Lapa que o Afrânio lhe pede que envie imediatamente o prefácio da Marília [de Dirceu] e tudo segue normalmente e ainda ao Hernâni que, por motivo de doença, ainda lhe não posso enviar pelo Angola o meu capítulo, que espero enviar brevemente. $^{70}$

Cortesão traz consigo a indicação de Hernâni Cidade, professor universitário de história da literatura portuguesa, e serve de intermediário entre este e Afrânio Peixoto, intelectual que presidira a Academia Brasileira de Letras (ABL) e fora reitor da Universidade do Distrito Federal, além de ter marcado presença na Academia de Ciências de Lisboa, instituição da qual Cortesão era membro e que constantemente aparecia junto a seu nome nos seus primeiros tempos de Brasil. Este, que é chamado na carta de amicíssimo, foi quem apresentou Cortesão, ao lado de Pedro Calmon, também membro da ABL e orador do Instituto Histórico e Geográfico Brasileiro (IHGB), em sessão especial na Academia ainda no ano de 1940. Em menos de um mês, no início de dezembro, Cortesão já havia sido convidado para proferir duas conferências remuneradas, uma em São Paulo e outra no Rio de Janeiro, na sede da Associação Brasileira de Imprensa. ${ }^{71}$

Afrânio Peixoto já era correspondente de Cortesão quando o intelectual português morava nas proximidades do canal Saint-Martin em Paris. Na missiva, o brasileiro permite identificar um dos elos entre ambos: o professor Le Gentil, professor da Sorbonne, de quem Peixoto tinha se desencontrado. O remetente promete prontidão quando Cortesão chegar ao Brasil, tomando como primeira providência a oferta de publicações históricas da Academia Brasileira de Letras, que não eram muitas nem muito importantes de seu ponto de vista, mas que para um historiador "certamente" não seriam desprezíveis. Conclui a mensagem demonstrando uma disposição em atende-lo que se estende a outros: "Qualquer

\footnotetext{
${ }^{70}$ CORTESÃO, J. Correspondência a Câmara Reys. Rio de Janeiro, 10 nov. 1940. In: CoRTESÃo, J. 13 cartas do cativeiro e do exilio (1940). Recolha, introdução e notas de Alberto Pedroso. Lisboa: Biblioteca Nacional, 1987, p. 77. A correspondência foi enviada poucos dias após a chegada de Cortesão ao Brasil e ao que sugere o texto, as remessas mencionadas seguem na viagem de retorno do navio em que ele veio, o S/S Angola. As complementações no corpo do documento são da edição da compilação de correspondências de Cortesão indicadas na bibliografia.

${ }^{71}$ CORTESÃO, J. Correspondência a Câmara Reys. Rio de Janeiro, 4 dez. 1940. In: CoRTESÃO, J. Op. cit., 1987, p. 81.
} 
mandado de V. Excia. será bem recebido lá". ${ }^{72}$ Cinco anos antes de chegar à Capital brasileira, o historiador português contava com a disponibilidade de Afrânio Peixoto e de uma rede que fica subentendida em sua mensagem. Fica também implícita na oferta do escritor brasileiro a real possibilidade de Cortesão vir a se instalar no Brasil ou ao menos de visita-lo.

Retomando a correspondência a Câmara Reys, quando da chegada de Cortesão ao Brasil, menciona-se um capítulo que haveria de mandar em breve para Portugal. Eram os textos Relações entre a Geografia e a História do Brasil e Expansão territorial e povoamento do Brasil, que seriam incluídos no terceiro volume da obra coordenada por Manuel Múrias e Hernâni Cidade, História da Expansão Portuguesa no Mundo. Cidade tinha enviado uma correspondência à Fortaleza de Peniche, onde Cortesão estava preso, em julho daquele ano, solicitando os textos que deveriam ser publicados no fascículo de agosto da obra. ${ }^{73}$ Até então, Cortesão tinha publicado textos mais gerais sobre o tema da expansão marítima empreendida pelos portugueses e alguns poucos dedicados ao Brasil em particular, entre eles o já citado A Expedição de Pedro Álvares Cabral e o Descobrimento do Brasil. Os textos sobre os quais vinha trabalhando no momento de sua chegada, entretanto, indicam um contato próximo com os temas sobre os quais se dedicaria ao longo de toda a sua estadia no Brasil. Desta forma, podem ser vistos como ainda outras credenciais para as suas colocações posteriores.

\section{Cortesão e os debates brasileiros: construindo um espaço, cartografando relações}

A construção das relações de Jaime Cortesão no Brasil precisa ser entendida no quadro da produção do conhecimento durante o período do Estado Novo brasileiro, marcado pela demanda, por parte do poder central, da participação dos intelectuais na vida pública da sociedade e nas discussões sobre a identidade da população e da nação. Esse imperativo não só diz respeito à relevância dos debates conduzidos a partir da instância estatal, no qual o programa cultural/educacional

\footnotetext{
72 Peixoto, A. Correspondência a Jaime Cortesão. Rio de Janeiro, 1 out. 1935. BNP/ACPC E25/729.

${ }^{73}$ CIDADE, H. Correspondência a Jaime Cortesão. Lisboa, 5 jul. 1940. BNP/ACPC E25/Caixa 69, Pasta 29.
} 
formava a espinha dorsal que sustentava o "homem novo para um Estado novo"74 como também se refere à ligação entre Cortesão e a "constelação Capanema": pessoas e órgãos ligados ao ministro da Educação à testa do amplo programa. ${ }^{75}$ Uma das instituições do ministério era a Biblioteca Nacional, local com o qual Cortesão possuiu vínculo formal entre 1946 e 1960, debruçando-se sobre documentos referentes às bandeiras, aos bandeirantes, aos jesuítas e às sociedades indígenas sulamericanas. Outra relação relevante nesse sentido diz respeito a outro ministro de Estado, Osvaldo Aranha, do Ministério das Relações Exteriores: junto desse ministro e de sua pasta, o historiador português trabalhou com documentação e pesquisa, realizou cursos para o pessoal do Ministério (nomeadamente diplomatas) e publicou trabalhos dedicados à cartografia histórica e à diplomacia, áreas em que se destaca a sua contribuição intelectual para o Brasil.

Não era a primeira vez em que a história e a geografia eram mobilizadas pelo Estado para interpretar e para definir o que era a nação: quando em 1838, às vésperas do Segundo Reinado (1840-1889), foi criado o Instituto Histórico e Geográfico Brasileiro (IHGB), o objetivo era o de definir as bases geográficas (território, natureza, riquezas) e históricas (grandes vultos e episódios, características sociais, políticas, culturais) do país recém-independente para dar-lhe a unidade almejada e considerada fundamental para a sua manutenção e reconhecimento como grande nação. $O$ período era de formação e consolidação do Estado Nacional. Nele, o saber históricogeográfico, interdependente, servia para esquadrinhar o Brasil e produzir a Nação, a partir de viagens exploratórias, reconhecimento de sociedades e de entidades físicas, geográficas e históricas, além de manter a comunicação com áreas de fronteira, vulneráveis às influências de países vizinhos, a partir do que propõe o texto de Manoel Luís Salgado Guimarães (2000). Colocado diante do problema em transplantar o conceito europeu de civilização para o Brasil, o Instituto identificava no indígena uma questão insolúvel, porém urgente, e o africano/afrodescendente,

\footnotetext{
${ }^{74}$ BomenY, H. Três decretos e um ministério: a propósito da educação no Estado Novo. In: PANDOLFI, Dulce (org.). Repensando o Estado Novo. Rio de Janeiro: Ed. FGV, 1999, p. 139. No texto em questão, a autora discute a forma pela qual a estruturação da educação em todos os seus níveis, especialmente aquela voltada para a infância, a adolescência e a juventude, visava à formação de uma "nova" sociedade que pudesse viabilizar o projeto de um "Estado Novo".

${ }^{75}$ Sobre as várias dimensões da política articulada a partir do gabinete do Ministro Gustavo Capanema, são essenciais as obras de SCHWARTZMAN, S.; BOMENY, H.; COSTA, V. (org.), 1984; GOMES, A. M. C. (org.), 2000 e BOMENY, H. (org.), 2001.
} 
escravizado praticamente em sua maioria, não chegava a ser, ao menos até então, uma questão. ${ }^{76}$ Segundo Reis,

O projeto do IHGB era geográfico e histórico. Geográfico, teria a tarefa de situar as cidades, vilas, rios, serras, portos, planícies; de conhecer e engrandecer a natureza brasileira, seu céu, clima, matas, riquezas minerais, flora e fauna; de definir os limites do território. Histórico, deveria eternizar os fatos memoráveis da pátria e salvar do esquecimento os nomes dos seus melhores filhos. Para isso, deveria coletar e publicar documentos relevantes para a história do Brasil, incentivar os estudos históricos, manter relações com as instituições congêneres do exterior (...). ${ }^{77}$

A partir da proposta de Como se deve escrever a história do Brasil do viajante naturalista bávaro Karl von Martius, vencedora de um concurso lançado pelo Instituto, propôs-se a orientação de narrar o Brasil a partir de suas características singulares, entre elas, a coexistência (não a relação) das três raças, capitaneadas pelo saber português, sem deixar de exaltar as peculiaridades da natureza do país. Diversas iniciativas então aliavam história e geografia, sociedade e natureza, a partir dos objetivos principais do Instituto, notadamente preocupado com a unidade social e territorial do país. ${ }^{78}$

No conhecimento que se construía, a geografia dos rios que correm para o oeste explicava historicamente a tendência da ocupação humana brasileira e dos caminhos que se formavam para o interior do continente, à época das atividades lideradas pelos membros do IHGB, como as expedições de esquadrinhamento do país. Esses caminhos eram considerados essenciais na consolidação dos limites territoriais brasileiros e pode-se dizer que, cerca de um século depois, ao menos as bases dessas ideias continuavam a ser discutidas.

Na década de 1930, passada a experiência da primeira etapa da República, o conhecimento histórico e geográfico foi novamente tomado como fundamento para (re)construir a nação. Dessa vez, no entanto, as bases eram distintas, menos eurocêntricas, na esteira das elaborações do pós-Primeira Guerra, quando os ideais civilizacionais europeus tinham caído em descrédito. Tanto o Brasil quanto outras

\footnotetext{
${ }^{76}$ GUIMARÃES, M. L. S. Nação e civilização nos trópicos: o Instituto Histórico e Geográfico Brasileiro e o projeto de uma História Nacional. In: Estudos Históricos, Rio de Janeiro, n. 1, 1988.

${ }^{77}$ ReIS, J. C. Identidades do Brasil: De Varnhagen a FHC. v. 1. $9^{\text {a }}$ ed. Rio de Janeiro: Ed. FGV, 2007, p. 26.

${ }^{78}$ Questões são discutidas nos trabalhos de GuIMARÃES, M. L. S. Op. cit., 1988; História e Natureza em von Martius: esquadrinhar o Brasil para produzir a nação. In: História, Ciências, Saúde Manguinhos, Rio de Janeiro, v. 7, n. 2, out. 2000.
} 
sociedades latino-americanas buscaram dentro de si próprias os elementos eleitos como originais na formação na nacionalidade. ${ }^{79}$

O panorama das áreas de conhecimento implicadas nesse trabalho, porém, passava por transformações. Para Alexandre Paiva do Rio Camargo, a organização do campo da Geografia no Brasil e a sua modernização foi desempenhada pela Revista Brasileira de Geografia, editada pelo Instituto Brasileiro de Geografia e Estatística (IBGE), organismo criado em 1936, e impulsionada pelas políticas territoriais do Estado Novo e pela difusão de novas metodologias de pesquisa. No primeiro aspecto, o político, a reorganização da Geografia asseguraria um processo sólido de interiorização do país. ${ }^{80}$ Do levantamento feito na Revista Brasileira de Geografia, Camargo constatou que, entre 1939 e 1947, alguns temas eram bastante recorrentes e faziam parte dos "temas quentes" da agenda governamental: "fronteiras, território, povoamento, regiões naturais, recursos minerais, cidades, levantamentos cartográficos e cartografia geral" e o seu debate era estimulado pela revista.

Aliado a isso, havia um movimento de valorização do homem e do mundo rural, viabilizando a sua fixação, especialmente nas áreas de fronteira - o que, além de garantir os limites nacionais favoreceria a construção de uma "consciência do povo brasileiro" -, partindo do pressuposto que ela estaria nesses rincões e era desconhecida do conjunto da população. ${ }^{81}$ Se no início o campo da Geografia brasileira estava sob a hegemonia da Geografia francesa, representada pelo pensamento de Vidal de La Blache, o quadro se alteraria após o alinhamento paulatino do Estado Novo com os Estados Unidos. Diante disso, cada vez mais geógrafos brasileiros iam estudar em universidades estadunidenses, financiados pelo governo daquele país. O campo da Geografia nos Estados Unidos, nos anos 1940, destacava-se, por sua vez, na área dos estudos sobre os processos de ocupação territorial, denotando o caráter instrumental da Geografia que estava em vias de formação/organização no Brasil. ${ }^{82}$

\footnotetext{
${ }^{79}$ Compagnon, O. L'adieu à l'Europe: l'Amérique Latine et la Grande Guerre. Paris: Fayard, 2013.

${ }^{80}$ CAMARGO, A. P. R. A Revista Brasileira de Geografia e a organização do campo geográfico no Brasil (1939-1980). In: Revista Brasileira de História da Ciência, Rio de Janeiro, v. 2, n. 1, jan.-jun. 2009, p. 23-24.

${ }^{81}$ CAMARGO, A. P. R. Op. cit., 2009, p. 26.

${ }^{82}$ CAMARgo, A. P. R. Op. cit., 2009, p. 31.
} 
Segundo Ângela Maria de Castro Gomes, a literatura sobre o processo de formação dos estados nacionais permite observar que nos momentos em que se dispende bastante energia para a implementação de projetos políticos, os dirigentes do Estado voltam-se para o passado e buscam dar-se um "lugar na história", reorientando leituras e escritas de fatos e interpretações do calendário cívico de um país. Nesse sentido, o Estado Novo brasileiro não é apenas marcante por suas iniciativas no campo da política e da economia como também o é na área intelectual. Isto porque, efetivamente, implementa uma consistente política cultural.

No caso do processo de produção e de divulgação da história da História do Brasil durante aquele período, Gomes o destaca como "um capítulo dessa política cultural mais abrangente, (...) como um investimento intelectual que se justifica pelo momento-chave que o processo de constituição do Estado nacional no Brasil atravessava". Como se tratava de uma nova proposta de organização do Estado e consequentemente de uma nova nação, o Estado Novo buscava uma nova legitimidade, buscando inscrever o seu lugar na história: era preciso refazer o próprio "sentido" da história do país.

Para alcançar os seus objetivos era imprescindível ao regime convocar intelectuais e especialistas para então recuperar e divulgar a história nacional, não somente no sistema educacional formal (que era redefinido e ampliado, para os padrões da época) mas também para fora dele. Nas palavras da autora, a projeção do novo Estado era o investimento na "produção de lealdade-legitimidade, que englobaria os futuros cidadãos e, sem dúvida, aqueles já definidos (ou ao menos potencialmente definidos) como tais". Tais iniciativas teriam então marcado a produção historiográfica brasileira posterior, seguindo a sua linha de análise. De acordo com a autora,

[a] ideia de nação brasileira como uma "porção de espaço" - como "território" com forte conotação cartográfica - é uma característica central dessa narrativa a ser examinada e "problematizada". Assim, a constatação (amplamente apontada pela literatura que trata da questão nacional no Brasil) da força e da persistência do uso de metáforas geográficas no discurso construtor da nacionalidade será tratada tanto como uma delimitação de fronteiras entre a história e a geografia, quanto como a busca do estabelecimento de relações complementares entre elas. ${ }^{83}$

\footnotetext{
${ }^{83}$ GoMes, A. M. C. Op. cit., 1999, p. 22-24.
} 
Para entender o papel de Cortesão no contexto da produção do conhecimento histórico e geográfico - ainda totalmente interdependentes, em vias de se autonomizarem, como aponta o estudo de Alexandre Camargo mencionado - é indispensável analisar os discursos da nacionalidade descritos no contexto do Estado Novo, que articulam a produção de conhecimento à marca da conquista do território. Prosseguindo com a interpretação de Ângela de Castro Gomes, tal articulação precisa ser examinada "sob a ótica da recriação de um processo histórico de afirmação do poder", que procede basicamente, mas não exclusivamente, da parte do Estado. O discurso do estabelecimento das fronteiras - geográfico - é, ao mesmo tempo, histórico, produto "de um longo e cuidadoso trabalho historiográfico, que pode assumir variadas formas de relacionamento entre a história e a geografia, de conotações do conceito de tempo e de demarcação e caracterização do que se entende por território". ${ }^{84}$

Ao discutir o lugar da história dentro das iniciativas do Estado Novo, ou, de uma "política cultural de recuperação do passado", Ângela de Castro Gomes lembra a Lei Orgânica do Ensino Secundário (Decreto-lei n 4.244, de 9 de abril de 1942), que deu à história do Brasil "o lugar que lhe competia", desvinculando-a da história geral. O ministro Capanema, por meio de portaria, já vinha revertendo a situação da disciplina desde 1940, completando a sua restauração dois anos depois. Nos títulos catalogados como de história do Brasil entre 1940 e 1943 e elencados na revista Cultura Política, vinculada ao DIP, são visíveis nomes já consagrados como historiadores: Afonso Taunay, Gilberto Freyre, Sérgio Milliet, Basílio de Magalhães, Alfredo Ellis Júnior e Cassiano Ricardo.

Quanto ao perfil temático, os assuntos recorrentes são o pacto colonial, as missões religiosas jesuíticas, a ação bandeirante, as questões de fronteiras e os movimentos separatistas, seguidos pelo escravismo e pela cafeicultura. Deduz-se disso que a maior parte trata do período colonial, um número proporcionalmente menor dedicado ao império e ainda menos ao período republicano. A República é analisada de forma separada, tendo destacado o seu período de gênese, e de forma equilibrada o fim da monarquia, a propaganda republicana e a Proclamação. Tal quadro esboçado expressa a "cultura histórica" do contexto do Estado Novo, no

\footnotetext{
${ }^{84}$ GOMES, A. M. C. Op. cit., 1999, p. 25.
} 
sentido do conceito usado por Le Goff, da relação que uma sociedade mantém com o seu passado. ${ }^{85}$

Considerando essas características que definem o estado da produção dos conhecimentos histórico e geográfico no Brasil, é possível lançar luz sobre a movimentação de Cortesão no interior dos debates nacionais, identificando convergências entre os seus pontos de vista e a cultura histórica do contexto que vivenciou no país em condições privilegiadas, no interior de instituições em que se produziam e a partir das quais se disseminavam tais conhecimentos. Jorge Borges de Macedo explicita a teoria da história de Jaime Cortesão colocando em evidência o fator geográfico, olhar segundo o qual o historiador relaciona a história e a geografia, partindo dos referenciais de Lucien Febvre e Vidal de La Blache. Sua interpretação, de acordo com Macedo, alia o espaço humanamente ocupado à significância histórica do fato geográfico. É notável, no conjunto de sua produção historiográfica, a centralidade dessa dimensão interpretativa, visível no estudo das bandeiras, do Tratado de Madri, da expansão marítima. O fator geográfico é um ponto de partida, entendido enquanto um ponto de suporte que ajuda "a perceber o problema da unidade em um determinado corpo social", embora não a garanta. Na sequência, ele se articula com a história social e com a história econômica, pelo caráter, pela "unidade espiritual", atingindo uma "história dos ideais coletivos" participando nos "debates necessários à sua realização". No caso português, o caráter social diz respeito a uma de suas mais conhecidas teses, a do humanismo universalista e franciscano que lançou as bases da aventura portuguesa da expansão. ${ }^{86}$

O tema das fronteiras do Brasil esteve presente no cotidiano de trabalho de Cortesão tanto na Biblioteca Nacional quanto no Itamaraty. Paralelamente, o historiador organizava a documentação da Coleção Pedro de Angelis e a Mapoteca dos Ministérios da Guerra e das Relações Exteriores, além de preparar os cursos dados no Instituto Rio Branco. As atividades se interpenetravam e a partir da natureza das fontes - relacionadas às Bandeiras, aos tratados de limites e à cartografia histórica do Brasil -, possibilitaram a escrita de uma história dedicada a essas problemáticas, articuladas às visões de mundo e aos projetos de Cortesão, bem como à sua forma de mobilizar o conhecimento histórico.

\footnotetext{
${ }^{85}$ GOMES, A. M. C. Op. cit., 1999, p. 146-150; 158.

${ }^{86}$ MACEDO, J. B. A teoria da História de Jaime Cortesão. In: Prelo, Lisboa, n. esp., dez. 1984, p. 63.
} 
$\mathrm{Na}$ obra que se originou do curso ministrado no Instituto Rio Branco, Cortesão afirma quais eram os principais objetivos daquela iniciativa, que narrava a História do Brasil nos Velhos Mapas:

Uma história do Brasil nos Velhos Mapas será, por definição e primazia, uma história do descobrimento, formação e soberania territorial do Brasil, exemplificada a cada passo pela cartografia antiga, comparada com a moderna. (...) Não se perca de vista que o Brasil é o único Estado do planeta, cujo descobrimento, e por consequência, formação territorial se prolongam desde os primórdios da sua história até aos nossos dias; e que sendo depois da Rússia o país de mais variada e complexa história de fronteiras, é também aquele em que os velhos mapas mais e melhor serviram de títulos justificativos de descobrimento, ocupação e posse, nos litígios de soberania com os demais Estados da América do Sul, - circunstâncias singulares que permitem escrever também esta obra, singular no seu gênero. Estado algum, dentre os Estados contemporâneos, tem a sua história política tão intimamente ligada à história da geografia da cartografia". ${ }^{87}$

O Brasil, explicado historicamente a partir dos documentos cartográficos, é apresentado como uma nação singular, cujo processo histórico de formação territorial se desenrola ao longo dos séculos. Os mapas são evidenciados como instrumentos de justificativa do descobrimento, da ocupação e da posse dos territórios nas disputas com os países fronteiriços.

Associado aos diversos fatores e experiências apresentados, a qualificação do processo de integração de Cortesão ao Brasil permite cartografar as suas relações com as teias das políticas cultural e territorial do Estado Novo. Ao que as fontes e a bibliografia indicam, as diversas iniciativas do governo de Getúlio Vargas nessas áreas não somente permitem a produção intelectual de Jaime Cortesão, que segue rumo aos sertões, como também viabiliza o seu destaque. Um dos projetos desse regime autoritário foi o de discutir e repensar a república e a democracia, dentro da perspectiva mundial de crise do modelo liberal de Estado e de exacerbação nacionalista. Conforme aponta uma parte da historiografia sobre o tema, pretendeuse uma nova forma de governar, sem intermediadores entre o poder Executivo e a população. Além disso, buscou criar um consenso - isento de conflitos - em torno da identidade nacional, dentro de um grandioso projeto político-cultural. ${ }^{88}$

\footnotetext{
${ }^{87}$ CORTesão, J. História do Brasil nos Velhos Mapas. t. 1. Rio de Janeiro: Ministério das Relações Exteriores, 1957, p. 5.

${ }^{88}$ Gomes, A. C. A política brasileira em busca da modernidade: na fronteira entre o público e o privado In: Schwarcz, L. M; NovaIs, F. (org.). História da Vida Privada no Brasil: contrastes da intimidade contemporânea. v. 4. São Paulo: Companhia das Letras, 1998, p. 515-516.
} 
O Estado Novo brasileiro (1937-1945), como estamos destacando, foi marcado por uma intensa política cultural, colocada em prática por meio de um aparato formado por órgãos como o Departamento de Imprensa e Propaganda (DIP), dirigido por Lourival Fontes (1934-1942), e o Ministério da Educação e Saúde, sob a batuta de Gustavo Capanema (1934-1945). Enquanto um intentava direcionar as manifestações da cultura popular, o outro se voltava para a formação de uma cultura erudita. ${ }^{89}$ A unidade - acima da diversidade/diferença - era um dos principais projetos de Vargas. Para tanto, a mobilização do pensamento brasileiro era fundamental para legitimar a construção de uma identidade capaz de abarcar a todos.

Para essa verdadeira missão, foi necessário chamar a intelectualidade à ação, depois de tirá-la de sua "torre de marfim".${ }^{90}$ Mônica Velloso considera Vargas o "pai dos intelectuais", por causa de sua tentativa de aproximar os homens de letras da República da esfera do poder. Com essa atitude, o Estado Novo demarcava sua premissa antiliberal: se no Estado liberal era permitido ao intelectual não se associar ao governo, nesse Estado corporativo ele é convocado para ser o "intérprete da vida social" por excelência e com a anuência do poder. ${ }^{91}$

O desejo de legitimidade de Vargas foi o que o levou a investir em uma imprensa que fosse a sua porta-voz (no caso, o jornal A Manhã , criado em 1941) e no patrocínio a intelectuais que, como disse Velloso, se tornariam intérpretes oficiais do país. A geração dos anos 1920, marcada pelo modernismo e pela construção de uma estética nacional, foi então privilegiada nos planos do Estado Novo, sendo uma parte dela chamada a ocupar cargos no Governo Federal. ${ }^{92}$ Além desses, e evidenciando a característica de um regime entre o tradicional e o modemo, diversos outros grupos, ligados aos partidos tradicionais, às correntes católicas, socialistas, integralistas e

\footnotetext{
${ }^{89}$ Velloso, M. P. Os intelectuais e a política cultural do Estado Novo In: Ferreira, J; Delgado, L. N. (org.) O Brasil Republicano: o tempo do nacional-estatismo do início da década de 1930 ao apogeu do Estado Novo. v. 2. Rio de Janeiro: Civilização Brasileira, 2003, p. 149.

${ }^{90}$ A "torre de marfim" estava representada especialmente pela Academia Brasileira de Letras (ABL). Vargas solicitou a instituição passar do pensamento à ação (VELLOSO, 2003, p. 150-151).

${ }^{91}$ VeLloso, M. P. Op. cit., 2003, p. 155.

${ }^{92}$ Figuras como Mário de Andrade tiveram bastante destaque nesse período, em que órgãos como o Serviço do Patrimônio Histórico e Artístico Nacional (SPHAN), Serviço Nacional do Teatro (SNT) foram criados (BOMENY, 2001). Ao longo do trabalho com a documentação de Cortesão, verificou-se a correspondência do historiador com Carlos Drummond de Andrade, que trabalhava no gabinete do Ministério da Educação e a presença de Guimarães Rosa em uma reunião do Itamaraty.
} 
outros, também tomaram parte na construção de uma nova identidade para o Brasil, sempre capitaneada por Getúlio e pelas diretrizes políticas de seu governo. ${ }^{93}$

Para Miceli, esse movimento provocou uma intensa burocratização do trabalho intelectual e das carreiras. Os que ocupavam posições estritamente administrativas confinaram suas pretensões intelectuais a um único gênero, quando não se dedicaram a obras literárias e textos de celebração política. De qualquer forma, diversos intelectuais tiveram condições favoráveis, institucional e materialmente falando, de modo a manterem-se no serviço público com os seus projetos pessoais, contando inclusive com o próprio Estado como "instância hegemônica de difusão e consagração de obras produzidas em tais circunstâncias". ${ }^{4}$

No caso de Cortesão, o seu currículo trazia o cargo de diretor da Biblioteca Nacional de Portugal, o que certamente concorreu para o seu ingresso como pesquisador na Biblioteca Nacional do Rio de Janeiro, na qual se tornou o responsável pela organização e publicação dos Manuscritos da Coleção De Angelis, documentação que serviu ao estudo das relações entre bandeirantes, jesuítas e indígenas no interior da América do Sul, em zonas então disputadas por castelhanos e portugueses ${ }^{95}$, assim como instrumentalizava a política de interiorização do país à medida que divulgava documentos relacionados à questão dos limites e fronteiras do Brasil. No mesmo contexto, Cortesão fora convidado para trabalhar na organização da mapoteca dos arquivos dos Ministérios da Guerra e das Relações Exteriores, no início de 1944, depois de pouco mais de três anos completos no Brasil, época em que recebera também o convite para ministrar um curso no recém-instalado Instituto Rio Branco, voltado para os futuros diplomatas brasileiros. O cargo é motivo de orgulho para muitos dos portugueses, como se percebe em duas entrevistas feitas com Cortesão.

O historiador José Honório Rodrigues, diretor da Divisão de Obras Raras e Publicações da Biblioteca Nacional entre 1946 e 1958, fez as honras de apresentador da publicação dos sete volumes dos Manuscritos da Coleção De Angelis, e atestou que

\footnotetext{
${ }^{93}$ BOMENY, H. Infidelidades eletivas: intelectuais e política. In: (org.). Constelação Capanema: intelectuais e políticas. Rio de Janeiro: Ed. FGV; Bragança Paulista: Ed. USF, 2001, p. 17.

${ }^{94}$ MiCELI, S. Op. cit., 2001, p. 198-199.

${ }^{95}$ Pimentel, J. S. Op. cit., 1952, p. 196. Segundo Nanci Leonzo (1984), foi a partir do contato com a referida coleção que Cortesão passou a se dedicar ao estudo das bandeiras, tendo como um dos principais mestres Afonso d'Escragnolle Taunay. Maria Beatriz Nizza da Silva informa que Cortesão teve um contrato de "pesquisador especializado" com a Biblioteca Nacional do Rio de Janeiro entre 1946 e 1960 (1985, p. 62).
} 
era um "dever esclarecer que esta edição obedece às diretrizes do Professor Jaime Cortesão, cujo saber e probidade científica autorizam o critério seguido". Rodrigues elencou uma série de atributos de Cortesão, referido como "historiador e paleógrafo, conhecido e reconhecido pelas suas altas virtudes de estudioso competente", cujo "conhecimento de cartografia, de geografia e de nossa expansão territorial forneceulhe as bases paleográficas e históricas para esta obra". Rodrigues também menciona a publicação da edição crítica da Carta de Caminha, na qual, pelo agradecimento feito por Cortesão, já se nota a relação entre ambos. ${ }^{96}$ Vale ressaltar que Honório Rodrigues também circulava entre a ABL o Itamaraty, espaços em que o historiador português também se fez presente. ${ }^{97}$

Pedro de Angelis (1784-1859), o colecionador dos manuscritos e de outros documentos, era um napolitano que tinha se estabelecido na Argentina, onde trabalhou para o governo do ditador Rosas (1830-1852), passando períodos no Uruguai e no Rio de Janeiro, servindo secretamente ao governo brasileiro, sendo também um admirador de D. Pedro II. Vendeu grande parte de sua coleção de manuscritos e documentos impressos, referentes em grande parte às missões jesuíticas espanholas na América do Sul, ao Brasil, em uma negociação intermediada pelos Viscondes do Rio Branco e do Uruguai, ministros dos Negócios Estrangeiros do Império. Em questão, o Rio da Prata e os diversos caminhos fluviais sulamericanos e a defesa dos limites entre os Estados constituídos. ${ }^{98}$

Cortesão agradece o apoio oferecido por José Honório Rodrigues, que além de oferecer as condições para o trabalho, também ofereceu a sua biblioteca pessoal para que a pesquisa fosse realizada. Outros historiadores também cederam as suas coleções pessoais para Cortesão, como Artur César Ferreira Reis. Em todos os

\footnotetext{
${ }^{96}$ RODRIGUES, J. H. Explicação. In: CORTESÃO, J. Jesuitas e Bandeirantes no Guairá (1594-1640). Rio de Janeiro: Biblioteca Nacional/ Divisão de Obras Raras e Publicações, 1951, p. 9. (Manuscritos da Coleção De Angelis, v. 1).

${ }^{97}$ De acordo com a sua biografia, apresentada pela Academia Brasileira de Letras, José Honório Rodrigues fora premiado aos 24 anos pela ABL por conta de seu estudo Civilização Holandesa no Brasil. Tempo depois, foi agraciado pela Fundação Rockfeller com uma bolsa de estudos nos Estados Unidos, onde pesquisou temas da história brasileira. Na mesma época em que fora diretor de Obras Raras e Publicações na Biblioteca Nacional, Rodrigues dirigira a Seção de Pesquisa do Instituto Rio Branco (1948-1951). Dedicando-se à área de relações internacionais e história, foi professor do Instituto Rio Branco (1946- 1956). Entre seus escritos encontram-se introduções e estudos de Capistrano de Abreu. Além de membro do IHGB e de outros Institutos Históricos estaduais, Rodrigues ingressou na ABL em $1969 . \quad$ Disponível em: $<$ http:/ $/$ www.academia.org.br/abl/cgi/cgilua.exe/sys/start.htm?infoid=749\&sid=323>. Acesso em 20 abr. 2014.

${ }^{98}$ CORTESÃO, J. Op. cit., 1951, p. 9.
} 
volumes (exceto um deles, organizado e lançado após a sua morte), o pesquisador agradece a uma de suas "colaboradoras e discípulas", a professora Olimiê de Lourdes Machado, auxiliar na transcrição e correção dos textos. ${ }^{99}$ Essa professora é também com quem Cortesão se corresponde durante a organização da Exposição de História de São Paulo, na qual figura como arquivista. ${ }^{100}$

$\mathrm{Na}$ qualidade de membro da Biblioteca Nacional, Cortesão cooperou com outras instituições congêneres, mediando o intercâmbio de cópias, originais, microfilmes de documentos de interesse brasileiro. Além disso, como será abordado no capítulo final, foi também enquanto funcionário da Biblioteca que o historiador cooperou com o projeto de reunião de documentos empreendido pelo Centro de Estudos Históricos Ultramarinos (CEHU), órgão vinculado ao Ministério do Ultramar do governo português do qual era vogal, criado em fins da década de 1950 para organizar o que se produzia a respeito da colonização portuguesa no passado e no presente.

O trabalho de Jaime Cortesão no Ministério das Relações Exteriores se deu entre 1944 e 1950. Segundo Francisco Roque Oliveira (2010), o período constitui o núcleo de sua atividade intelectual no Brasil. O principal objetivo dos cursos ministrados no Instituto Rio Branco era o de trabalhar a questão das fronteiras brasileiras em perspectiva histórica, do passado ao presente, tomando assim parte de um dos principais assuntos trabalhados no período. Um dos padrinhos do intelectual português no Itamaraty foi o próprio Ministro das Relações Exteriores, Osvaldo Aranha, que em 1942, havia convidado Cortesão para organizar um Atlas Histórico do Brasil, obra que não saiu do papel e cuja iniciativa, a de convidar um português para a atividade, foi bastante criticada pelos historiadores brasileiros de então. ${ }^{101}$

No gabinete do secretário do Ministério das Relações Exteriores, na presença do Diretor do Instituto Rio Branco, Hélio Lobo, do Embaixador Lafayette Carvalho, do chefe do Serviço de Documentação, o escritor Guimarães Rosa, do chefe da Mapoteca, Luiz C. de O. Neto, de Isa Adonias e Astreia Dutra, foi lido o texto do projeto do atlas planejado por Cortesão a pedido do Ministro Osvaldo Aranha, a

\footnotetext{
${ }^{99}$ CORTESÃO, J. Op. cit.,1951, p. 91.

${ }^{100}$ CORTESÃO, J. et al. Exposição de História de São Paulo no quadro da História do Brasil. Catálogo. Datil., 308 fl., [São Paulo], [1954/1955]. BNP/ACPC E25/Cx. 64, Pasta 20.

${ }^{101}$ OliveIRA, F. R. História da Cartografia Brasileira e Mapoteconomia segundo Jaime Cortesão: o curso do Itamaraty de 1944. In: Anais do IV Simpósio Ibero-americano de História da Cartografia. São Paulo, 2010.
} 
princípio orientado a partir de duas tendências: a de um Atlas Histórico "magistral", que apresentaria cartogramas com o resultado da elaboração científica do maior número possível de dados históricos e histórico-estatísticos e a de um instrumento de trabalho direcionado a historiadores e diplomatas, "reunindo os melhores títulos de justificação e defesa da soberania territorial do Brasil", dando continuidade à herança do Barão do Rio Branco. O Atlas era organizado em seis partes: Introdução; Descobrimento dos Litorais e reação ao Tratado de Tordesilhas; Realização geográfica da Ilha-Brasil: as bandeiras fluviais, ocupação holandesa e restauração portuguesa; Expansão mineira e Antecedentes do Tratado de Madrid; Defesa diplomática e definição dos limites; Consolidação dos limites e organização do Brasil independente, Império e República. ${ }^{102}$

Sua atuação na área de influência do Itamaraty não ficava restrita a esse ministério. Cortesão participava de eventos e reuniões de outros órgãos do Governo Federal, como do Instituto Brasileiro de Geografia e Estatística (IBGE), que realizava tertúlias geográficas semanalmente. $\mathrm{Na} 59^{\text {a }}$ edição, em 4 de abril de 1944, o historiador português apresentou o curso de História da Cartografia que seria oferecido. Leite de Castro, presidente da sessão, dispensou maiores apresentações de Cortesão, alegando ser desnecessária face à "fulgurante personalidade" de quem tinha "identificado perfeitamente o Brasil". Jaime Cortesão discorreu sobre o programa geral do curso, cujo primeiro passo foi o de inventariar a cartografia antiga no Rio de Janeiro presente nos arquivos do Itamaraty, enriquecida por novas aquisições do chanceler Osvaldo Aranha. Ressaltou ter aceitado a incumbência "pelo sentimento de servir ao Brasil". ${ }^{103}$ Seja para fazer frente às resistências que seu nome apresentava, quando associado às questões nacionais, seja por desejo de colocar-se à serviço do país que o acolhia, Cortesão não raro declarava publicamente o "sentimento de servir" ao país, o que poderia então servir de escudo diante de eventuais críticas que se fizessem à sua escolha.

No período em que esteve vinculado ao Itamaraty, seus cursos deram origem a publicações, lançadas sob o selo do Ministério. Às vésperas do bicentenário do

\footnotetext{
${ }^{102}$ CORTESÃO, J. [História da Cartografia, X]. BNP/ACPC E25/94. Documentos diversos sobre o plano do Atlas Histórico do Brasil agrupados. Documento sem data.

${ }^{103}$ IBGE. Ata da 59 $9^{a}$ Tertúlia Geográfica Semanal. Rio de Janeiro, 4 abr. 1944. BNP/ACPC E25/2022.

Também disponível em:

<http://biblioteca.ibge.gov.br/visualizacao/periodicos/19/bg_1944_v2_n15_jun.pdf>. Acesso em 16 nov. 2014.
} 
Tratado de Madri, assinado em 1750, Cortesão foi solicitado para escrever um trabalho para compor as comemorações: foi assim que nasceu Alexandre de Gusmão e o Tratado de Madrid (1750), publicado em nove tomos a partir de 1949. Na introdução da obra, o autor destaca as dificuldades encontradas na recolha das fontes, dispersas em arquivos europeus (e com os quais ele tinha algum contato). Reconhece o trabalho "de equipe" necessário para viabilizar o estudo, que conta com Agostinho da Silva, também português, exilado no Brasil e genro de Cortesão, pesquisadores e arquivistas brasileiros e portugueses, entre outros. $\mathrm{O}$ agradecimento a Afonso Taunay, que se destaca em um parágrafo dos outros, deve-se ao fato de que o historiador do Museu Paulista tenha trocado diversas informações sobre Alexandre de Gusmão com Cortesão. ${ }^{104} \mathrm{O}$ único nome que compartilha o espaço no parágrafo é o de Afrânio Peixoto, o mesmo que apresentou historiador português à ABL quase dez anos antes.

Para além dos agradecimentos feitos a embaixadores, ministros, diretores de arquivos e bibliotecas, finaliza, no último parágrafo, agradecendo os "auxílios de vária ordem", entre os quais se encontram os nomes de um professor da Universidade de Coimbra, Rebelo Gonçalves e Charles Boxer, britânico, um dos principais nomes da historiografia do império marítimo português, do King's College. Entre outros nomes de professores e historiadores, agradece ao irmão sem se referir ao parentesco, Armando Zuzarte Cortesão, historiador da cartografia e funcionário da UNESCO, em Paris. ${ }^{105}$

As outras atividades realizadas dentro do Ministério e também as referentes às outras pastas do Executivo Federal dialogavam entre si e Cortesão não estava alheio aos assuntos que eram trabalhados em áreas distintas do aparelho do Estado. Os estudos referentes ao projeto do novo Distrito Federal, desde o século anterior já pensado para a região do planalto central, no estado de Goiás, tiveram a participação do historiador português, que fez uma apreciação técnica, cartográfica e histórica da região, explicada a partir do bandeirismo e da hidrografia da região, com base em documentos remetidos pelo Conselho de Imigração e Colonização. ${ }^{106}$

\footnotetext{
104 Cortesão, J. Correspondência a Afonso Taunay. Rio de Janeiro, 09 ago. 1949. 1 fl. Museu Paulista, ARQ 94.1, pasta 3. Cortesão, dirigindo-se a Taunay como mestre e amigo, pede-lhe informações sobre Alexandre e Bartolomeu de Gusmão.

${ }^{105}$ CORTESÃo, J. Alexandre de Gusmão e o Tratado de Madrid (1750). v. 1. Ed. fac-similar. São Paulo: Imprensa Oficial/ Brasília: FUNAG, 2006, p. 5-7.

106 O Conselho de Imigração e Colonização havia sido instituído em 1938 e era subordinado à Presidência da República. Era responsável por fixar cotas para a imigração e fiscalizá-las de acordo
} 
Cortesão destaca a importância geopolítica do planalto, fundamental para a integração e para o desenvolvimento nacionais, mencionando o imenso "organismo vivo" e os "sistemas circulatórios" do território brasileiro, cujo corpo tem como coluna vertebral os rios Tocantins e São Francisco, comunicando as bacias amazônica e platina. De seu ponto de vista, a plena realização econômica e demográfica do país dependia da utilização das possibilidades daquela grande estrada fluvial a interligar o Brasil do Norte ao Sul. Em se tratando da "vocação para o Oeste" do país, o autor sugere a exploração do eixo Tocantins-Araguaia, considerados na totalidade de suas conexões fluviais. A descoberta do ouro teria demonstrado pela primeira vez a posição estratégica do planalto central, uma "grande encruzilhada dos caminhos" brasileiros, integrando historicamente os dois Estados: do Maranhão e do Brasil. ${ }^{107}$ Em uma versão acabada do mesmo texto, Cortesão descreve um apanhado geral do plano da construção da nova Capital do país, elencando as iniciativas sobre o assunto desde o século anterior, apresentando o empenho do presidente Getúlio Vargas em dar impulso para a concretização da construção, abrindo um largo debate sobre como realizar o projeto, levando em conta as diversas necessidades do país. Nesse segundo texto, o autor buscou definir uma "geopolítica da futura capital", buscando tirar das soluções dadas no passado a problemas semelhantes as "premissas do futuro". ${ }^{108}$

Além disso, o contato com outros professores e atividades do Instituto Rio Branco permite vislumbrar algumas das frentes de trabalho do Ministério em

com dados do Ministério das Relações Exteriores e do Departamento de Imigração, de modo a disciplinar o assento de estrangeiros no país e "assimilá-los", evitando também a sua concentração. Instrumento crucial do ponto de vista da concepção de "soberania" e de "identidade nacional" apregoados pelo regime, o Conselho também se propunha como instância responsável pelo estudo dos "problemas relativos à seleção imigratória, à antropologia étnica e social, à biologia racial e à eugenia", estando assim também em sintonia com o pensamento em voga em outras partes do mundo. O órgão também trabalharia com as correntes migratórias internas e a permuta de trabalhadores rurais entre estados, visando ao equilíbrio da sua distribuição no território nacional. O Conselho existiu até 1954, quando o próprio Vargas o transformou em Instituto Nacional de Imigração e Colonização, sob jurisdição do Ministério da Agricultura. Os termos referentes à raça e eugenia foram suprimidos do estatuto da nova organização, buscando promover a fixação de imigrantes e o maior acesso dos nacionais à pequena propriedade agrícola. Reformulado nos anos seguintes, o órgão originou o atual Instituto Nacional de Colonização e Reforma Agrária (INCRA), vinculado ao Ministério do Desenvolvimento Agrário. A esse respeito, ver: Decreto-Lei 3.691, de 6 fev. 1939; Lei Federal n. 2.163, de 5 jan. 1954.

${ }^{107}$ CORTESÃO, J. Cartografia antiga e geo-politica de Goiaz. Rio de Janeiro, 31 ago. 1950. 28 f./41 f. BNP/ACPC E25/37. Carta de remessa de documentos e cópias cartográficas do Conselho de Imigração e Colonização da Presidência da República.

${ }_{108}$ CORTESÃO, J. Geo-política de Goiaz e da futura capital. [Rio de Janeiro, 1957]. 20 f. BNP/ACPC $\mathrm{E} 25 / 49$. 
particular e do Governo em geral. Documentos guardados por Cortesão de outros cursos do Itamaraty sugerem alguns de seus interesses e eventual participação: foram cursos de 1945, sendo o de "Geografia Econômica da América Latina", de Affonso Várzea; "Geografia e Política do Brasil e da América Latina" e "Geopolítica" de Everardo Beckheuser e "Geografia e cultura brasileira e da América Latina", ministrado por Francisco Raja Gabaglia. Além disso, junto dos mesmos programas, encontra-se um roteiro de visitação às obras do Centro Nacional de Ensino e Pesquisas Agronômicas, criado em 1938 e com a sua construção concluída em 1944 no município de Seropédica, próximo à cidade do Rio de Janeiro. O Centro é uma das bases sobre as quais se constituiu a Universidade Rural do Brasil, atualmente Universidade Federal Rural do Rio de Janeiro. ${ }^{109}$

Em setembro de 1943, portanto antes de Cortesão começar a ministrar os seus cursos no Instituto Rio Branco, acontecia no Palácio Itamaraty a Exposição de Cartografia Brasileira, ocasião em que o historiador português proferiu uma série de lições intitulada Como se esboçou o retrato do Brasil, iniciada a partir da abertura da exposição em solenidade presidida pelo chanceler Osvaldo Aranha. ${ }^{110} \mathrm{O}$ retrato expresso na cartografia seria, portanto, uma das características visuais da nação, em um sentido que se aproxima da reflexão de Benedict Anderson sobre os modos de definir e caracterizar a comunidade imaginada que é a nação. ${ }^{111}$

Quando entrevistado em Portugal, um ano depois de seu retorno, Cortesão fala de seu trabalho no Itamaraty, motivo de orgulho para muitos portugueses segundo o entrevistador Igréjas Caeiro, no programa Perfil de um artista do Rádio Clube Português:

(...) [O] Governo brasileiro confiou-me missões da mais alta importância. Eu fui professor no Itamaraty do curso de aperfeiçoamento de Diplomatas e nem mais nem menos do que da Cadeira de História da Formação do Brasil, da formação territorial do Brasil, isto é, a história dos problemas de fronteiras que o Brasil tem com dez nações. É, de fato, uma missão honrosíssima. Não tenho senão que me orgulhar e desvanecer dela e suponho que trabalhos anteriores à minha chegada ao Brasil e aqueles que realizei no Brasil antes de me serem confiados esses cursos, levaram o Governo brasileiro a oferecer-me essa cadeira". ${ }^{112}$

\footnotetext{
${ }^{109}$ CORTESÃO, J. [História da Cartografia, VII]. Rio de Janeiro, 1944-1945. 249f./ 41f. BNP/ACPC $\mathrm{E} 25 / 91$

${ }^{110}$ In: A Manhã, Rio de Janeiro, 29 ago. 1943, p. 5.

${ }^{111}$ ANDERSON, B. Comunidades imaginadas: reflexões sobre a origem e a difusão do nacionalismo. São Paulo: Companhia das Letras, 2008.

${ }_{112}$ Entrevista transcrita em SANTOS, A. R. Op. cit., 1993, p. 347.
} 
Cortesão não apenas reconhece a importância do cargo que ocupou como estava a par das consequências de suas atividades em um curso voltado para as relações internacionais. Segundo Francisco Roque Oliveira (2010), os cursos tinham como base uma didática que possibilitava aos alunos notar a articulação entre a composição dos mapas estudados e os "fundamentos geopolíticos da identidade do Brasil". Desse modo, atestava-se a função que aquele conhecimento produzido tinha para as políticas governamentais, especialmente aquelas relativas ao território, assim como possibilitava a instrumentalização de assuntos da política cultural.

Segundo Maria Beatriz Nizza da Silva, em nenhum outro lugar o historiador dispôs de melhores condições do que no Ministério das Relações Exteriores/Instituto Rio Branco e na Biblioteca Nacional. Essas condições que vão dos recursos humanos e materiais às relações com arquivos e documentação no exterior, bem como a possibilidade de publicar os textos em editoras especializadas, do próprio aparelho do Estado:

O Instituto Rio Branco foi, juntamente com a Biblioteca Nacional, a instituição brasileira que melhores condições de trabalho ofereceu ao historiador português exilado. Nela Cortesão encontrou não só um núcleo de discípulos de escol, como também uma equipe de trabalho e uma infraestrutura que lhe permitiram não cortar as amarras com os arquivos europeus e sobretudo portugueses que tão bem conhecia. E ainda um centro vivo da cultura nacional e uma editora que aceitou a publicação de numerosos e importantes volumes que nenhuma editora comercial publicaria. Por seu lado, o Instituto Rio Branco encontrou no historiador português o mestre e o pesquisador de que tanto precisava para se consolidar como instituição prestigiosa logo após a sua criação. Encontros felizes como este são raros na história da cultura brasileira como na história da cultura portuguesa". ${ }^{113}$

Isa Adonias, vinculada ao Itamaraty e ao IHGB, publicou, no transcurso do centenário de nascimento de Cortesão em 1984, uma homenagem intitulada Jaime Cortesão e seus mapas: instrumentos didáticos para a História da Cartografia do Brasil. No texto, lembra que quando havia sido realizado o Curso de História da Cartografia do Brasil, Geografia das Fronteiras do Brasil e Mapoteconomia, em 1944, o intuito do Ministério era o de criar quadros capacitados para o trabalho com o material cartográfico sob a sua guarda. Na trilha desses objetivos, fomentava-se a ideia de criar o que veio a ser o Instituto Rio Branco, em condições apresentadas pelo diplomata Jorge Latour, responsável pelo Serviço de Documentação do Itamaraty.

\footnotetext{
${ }^{113}$ Silva, M. B. N. Cortesão no Instituto Rio Branco. In: Prelo, Lisboa, n. esp., dez. 1984, p. 141.
} 
A proposta era a de preparar e aperfeiçoar a "mocidade com destino à diplomacia, às atividades consulares, às econômicas e comerciais, e às culturais, na vida de relação na nação brasileira" - em linhas gerais, o Itamaraty tornar-se-ia um ambiente acadêmico-universitário, abrindo o caminho para a instalação de outros cursos, como Arquivologia e Biblioteconomia aplicadas ao Ministério. ${ }^{114}$

De qualquer modo, a iniciativa do curso de História da Cartografia, ministrado por Cortesão, autointitulado cartólogo, e por Murilo de Miranda Basto, então chefe da Mapoteca do Ministério, foi um curso inédito no país, que pela primeira vez abordou a documentação cartográfica antiga do Brasil, que estava representada em grande parte na coleção do Ministério. O curso inovou tanto no sentido do estudo sistemático daquelas fontes quanto no de sua "utilização sua utilização metodológica na interpretação e esclarecimento de fatos e momentos históricos". ${ }^{115}$ Dos trabalhos nesse curso foi produzido o livro História do Brasil nos Velhos Mapas, publicado pelo Instituto Rio Branco/Ministério das Relações Exteriores em dois volumes, em 1957, ano em que Cortesão retorna definitivamente a Portugal. Para a obra, Cortesão havia retornado a Portugal em 1952, em missão pelo Itamaraty à procura de documentos cartográficos relativos ao Brasil, sendo recebido calorosamente pelos amigos seareiros que lhe dedicaram um número especial em homenagem no final daquele ano. Na ocasião, Cortesão também prestou serviços à Comissão do IV Centenário da Cidade de São Paulo.

\section{Um historiador luso-brasileiro}

A Fundação Alexandre de Gusmão, do Ministério das Relações Exteriores, responsável pela difusão cultural da memória diplomática brasileira e dos assuntos referentes à política externa atual, publicou em 2006 uma edição fac-similar em dois volumes da primeira edição de Alexandre de Gusmão e o Tratado de Madrid (1750), originalmente impressa em nove tomos, lançados a partir de 1949. No prefácio da obra, o então ministro das relações exteriores Celso Amorim (2003-2010) qualificou o estudo de Cortesão como de grande porte e nunca superado. ${ }^{116}$ Tais considerações

\footnotetext{
114 AdONIAS, I. Jaime Cortesão e seus mapas. Rio de Janeiro: IHGB, 1984, p. IX-X.

${ }^{115}$ ADONIAS, I., Op. cit., 1984, p. XIII.

${ }^{116}$ AmORIM, C. Prefácio. In: CORTESÃo, J. Alexandre de Gusmão e o Tratado de Madrid (1750). v. 1. Ed. fac-similar. São Paulo: Imprensa Oficial/Brasília: FUNAG, 2006, sem paginação.
} 
se somam às outras que reconhecem ou enaltecem o trabalho de Cortesão no Brasil, em especial quando se trata dos textos relacionados à história da formação territorial do país, área em que sua contribuição ganhou destaque. A declaração do então ministro Celso Amorim atesta o valor da obra magna de Jaime Cortesão, justifica a sua republicação quase seis décadas depois.

A obra-magna de Cortesão havia sido lançada cerca de dez anos depois do seu desembarque no porto carioca. Ao longo desse período, o historiador se integrou às redes relacionais que estavam próximas da área direta de influência do Governo Federal, durante e vigência do Estado Novo e após o seu término. O contexto também é impregnado pela Segunda Guerra Mundial, conflito que reorganizaria as relações internacionais naquele tempo e nas décadas seguintes. Considerando a nova publicação de Alexandre de Gusmão, viabilizada mais uma vez pelo Ministério das Relações Exteriores, denota-se a sua efetiva contribuição para a área das relações internacionais no Brasil, destacando-se em meio às suas outras atividades em terras brasileiras. À sua época e tanto tempo depois, chanceleres brasileiros dão legitimidade à produção do texto sobre um dos principais vultos da história da diplomacia brasileira, cujo nome é emprestado à fundação responsável por divulgar trabalhos e atividades do Itamaraty. Osvaldo Aranha, o Ministro das Relações Exteriores que inaugurou, em sessão solene, o primeiro curso de Cortesão, consagrou o historiador português, como notou e anotou Sarmento Pimentel, que se dizia sempre atento aos elogios destinados ao amigo e compatriota:

$\mathrm{Na}$ solenidade da aula inaugural do primeiro curso no Itamaraty, ouvi eu dizer ao chanceler Osvaldo Aranha, para os alunos, cônsules, Embaixadores estrangeiros, ministros e numerosa assistência de quanto de melhor e mais culto se constitui a sociedade carioca: os professores do Instituto Rio Branco sempre foram nacionais. Abrimos até hoje uma exceção, chamando a colaborar conosco o ilustre e sábio professor Dr. Jaime Cortesão que bem merece, por todos os seus títulos esta honra. É verdade que, como português, que tanto se orgulha em o ser, nós não o consideramos estrangeiro. ${ }^{117}$

Segundo Antônio Candido, a "missão portuguesa", de intelectuais principalmente oposicionistas ao governo português, se deu de forma natural, não organizada, formando um "agrupamento virtual de grande importância, que pesou mais do que se pensa em muitos setores". Abrangendo o território brasileiro de forma ampla e alcançando diversas áreas do conhecimento, a missão contribuiu para o

${ }^{117}$ Pimentel, J. S. Op. cit., 1952, p. 196. 
adensamento de nossa cultura. ${ }^{118}$ No contexto da política nacionalista de Vargas, as relações com Portugal foram estreitadas, olhando para o país ibérico como a raiz da nação americana. Para o ministro Osvaldo Aranha, o Brasil era "amigo de todos os povos, mas, filho, só de Portugal". Capanema afirmava que "os brasileiros se orgulhavam de ser portugueses na América". Diversos acordos de cooperação entre os dois países eram firmados, inclusive no campo da língua. Desde 1931, um acordo teve por objetivos a preservação da unidade e a promoção da expansão da língua portuguesa. ${ }^{119}$

Tais dados ajudam a completar o quadro sobre o exílio e também qualificar as categorias estrangeiro/nacional aplicadas aos intelectuais portugueses que se radicaram no Brasil naquele contexto. Ainda que houvesse uma predisposição a considerar os lusos como mais brasileiros do que outros estrangeiros, há que se considerar os momentos em que o fato de não ser nacional era questionado, como ocorreu quando da indicação de Cortesão para a organização do Atlas Histórico do Brasil e mesmo na elaboração da Exposição de História de São Paulo. Nesse sentido, a declaração de Osvaldo Aranha pode ser tomada como uma relevante forma de reconhecimento.

A hipótese mais plausível para explicar o reconhecimento de Cortesão como não estrangeiro - um historiador luso-brasileiro - está no seu grau de envolvimento com os debates locais à época, que apesar de dizerem muito respeito às raízes portuguesas do Brasil, estavam na ordem do dia do país. Além disso, seu trânsito entre espaços diversos e até politicamente antagônicos lhe proporcionou uma exposição destacada no contexto em muitas das principais instituições, órgãos de imprensa e cidades do país. É possível afirmar que toda essa circulação - embora se possa também falar em duas etapas, uma carioca e outra paulistana -, só seria possível a um estrangeiro, que acima das disputas locais estivesse envolvido com discussões de interesse do país, que encontravam pontos comuns em um e em outro lado.

No momento em que Cortesão partiu de Portugal pela primeira vez, não saiu do continente europeu. Àquela altura, o escritor ainda não estava na lista dos

\footnotetext{
118 CANDido, Antonio. Prefácio. In: Lemos, F.; Leite, R. M. (org.) A Missão Portuguesa: rotas entrecruzadas. Bauru: EDUSC; São Paulo: Ed. UNESP, 2003, p. 15.

${ }^{119}$ GUIMARÃES, L. M. P. Relações culturais luso-brasileiras: alguns pontos de confluência. In: Revista Convergência Lusíada, Rio de Janeiro, n. 24, 2007, p. 259.
} 
obrigados a deixar o país e mantinha-se ativo na atuação política diretamente voltada para a realidade portuguesa. Outros seareiros e intelectuais portugueses, como Sarmento Pimentel, muito próximo de Cortesão, já tinham optado pelo Brasil como residência desde então. Jaime Cortesão somente embarcou rumo ao Rio de Janeiro por força das circunstâncias, como vimos, quando foi preso e banido de seu país em 1940.

Em um trecho de uma entrevista de 1958 que já vimos anteriormente, são proferidas duas frases encadeadas, em resposta à pergunta sobre as lições que a experiência brasileira teriam lhe oferecido. A ideia exprime a forma como o intelectual quis sintetizar o seu enraizamento no solo tropical: na primeira consagra o Brasil como o único país capaz de substituir Portugal para um português e, na seguinte, diz considerar a vivência no Brasil como capaz de proporcionar o contato com um "Portugal mais português que o da metrópole". Ao expressar com essas imagens o processo de migração e de enraizamento em outra terra, o escritor possibilita a visualização de um paralelo com a ideia que segue em sua réplica, a de um Portugal que permanece na ex-colônia por meio de características "transplantadas" e aclimatadas não sem "terríveis problemas de adaptação a resolver". Seguindo o raciocínio de sua construção, a compreensão do sentido da colonização é uma grande e proveitosa lição que um português dos novecentos deveria transformar em "programa de ação". Com a resposta, Cortesão narra o seu processo de "transplante" dando sentido às suas ações no Brasil, iluminado por uma compreensão da história da colonização portuguesa.

Interpretando a sua fala enquanto forma de dar um sentido à experiência passada, um sentido por assim dizer teleológico e funcional, duas questões podem ser discutidas à luz da caracterização do contexto que pudemos avaliar até o momento. A primeira diz respeito ao modo como Cortesão via o Brasil em relação a Portugal e a segunda se refere à função que desempenharia a compreensão da história da colonização portuguesa no tal "programa de ação" que o orientava. A resposta a esses questionamentos elucida não apenas a sua integração ao universo brasileiro, a ponto de não ser mais uma pátria estranha, como também fornece argumentos para a interpretação dos caminhos trilhados por sua escrita da história.

$\mathrm{Na}$ mesma entrevista, Cortesão oferece um diagnóstico sobre como via o Brasil no contexto do pós-guerra, com um olhar que certamente levava em conta as 
dinâmicas do trabalho na área das relações internacionais em que esteve diretamente implicado desde os seus primeiros tempos no país. Respondendo à pergunta sobre como poderia ser entendido o seu "programa de ação", Cortesão explicou nestes termos:

O Brasil é hoje uma nação essencialmente americana, com tendências, interesses e ideais americanistas. Está em plena formação e transformação, com o afluxo constante de emigrantes de várias nações, alguns, como os italianos, de uma alta civilização afim como a nossa; outros como os alemães ou os sírios, de uma cultura muito diferente. Certos setores da população, ainda tão heterogênea, tendem a esquecer, quando não a depreciar, as origens portuguesas do Brasil. A todo e qualquer português cabe, pois, ali, uma ação catalisadora: marcar, pela simples presença e uma conduta exemplar, a substância, a excelência e o prestígio daquelas origens. Um escritor e um professor, como tenho sido no Brasil durante muitos anos, pode e deve, no jornal, no livro ou na cátedra, dentro da livre discussão e sempre com o devido respeito ao que há de novo e original na sua formação e tendências, afirmar o que, apesar dos erros inevitáveis, houve de benéfico na ação colonizadora dos Portugueses. Esse foi constantemente o meu programa. ${ }^{120}$

Quando Cortesão lançou a Coleção Clássicos e Contemporâneos, em 1943, fez um apelo à comunidade portuguesa no país para que se empenhasse no trabalho de resgate da cultura lusitana no Brasil, por ele chamada de "luso-brasileira". Ancorando-se em uma fala de Gilberto Freyre, o historiador conclamava os seus compatriotas, em situação de exílio ou não, a fazer frente a uma referida ameaça às raízes portuguesas do Brasil. Nesse outro trecho da entrevista, ao chamar o Brasil de nação essencialmente americana, Cortesão qualifica o que poderia ser visto como ameaçador à essência portuguesa do país, que assume tendências, interesses e ideais americanistas: tal quadro, associado ao afluxo de diversos imigrantes de diversas culturas, cria uma heterogeneidade que tende ao esquecimento e à depreciação das origens portuguesas do país.

Cortesão está, na entrevista, visualizando a sua trajetória e dando a ela um significado, como já disse anteriormente. O olhar para o espelho apresenta um sujeito que cumpriu com a sua missão de relevar a excelência das origens portuguesas nas diversas frentes em que atuou, não permitindo que os benefícios da ação colonizadora portuguesa se perdessem em meio à transformação pela qual passava o Brasil. Colocando lado a lado as duas respostas dadas pelo intelectual, é possível

\footnotetext{
${ }^{120}$ CORTESÃO, J. Jaime Cortesão. Entrevista a entrevistador não identificado. Lisboa, 10 abr. 1958. In: DiÁRIO DE NOtíCIAS. Palavras no tempo: v. 2 - Cultura. Lisboa: Imprensa Nacional/Casa da Moeda, 1991, p. 61. Grifos meus.
} 
chegar à conclusão de que os traços que fazem do Brasil "mais português do que a metrópole", que são também os do Portugal ideal com o qual Cortesão se aproximou depois de sua partida em 1927, são os que precisam de cuidado especial. O autor vê o Brasil como realização plena de Portugal e, uma vez ameaçadas as raízes, estaria em risco a herança.

Nesse aspecto, a compreensão da história da colonização, entendidos os erros como inevitáveis e focando-se nos seus beneficios, era a chave que permitiria o acesso dos brasileiros a uma narrativa que não escamoteasse as suas raízes portuguesas. Pode-se dizer que a pretensão do "programa de ação" de Cortesão visava à reabilitação da história colonial, que àquela altura já vinha sendo caracterizada como a matriz dos defeitos por alguns intelectuais ${ }^{121}$, assim como por contingentes supostamente significativos da população. Ainda na ocasião, Jaime Cortesão identifica a sua atividade em terras brasileiras como não sendo "própria e diretamente portuguesa", embora tal afirmação deixe evidente a sua lusitanidade. De sua perspectiva, a sua escrita histórica foi brasileira, pretendendo se dedicar especificamente à história de Portugal dali em diante, apesar de suas facilidades de trabalho no Brasil. ${ }^{122}$

Ao final do primeiro ano de trabalho de Cortesão no Itamaraty, o embaixador Leão Velloso propôs à Presidência da República o ingresso do historiador português à Ordem Nacional do Cruzeiro do Sul, diplomação que é entregue a pessoas estrangeiras que tenham se tornado "dignas de reconhecimento da Nação brasileira", em condecoração regida por ato da Presidência e do Ministério das Relações Exteriores. ${ }^{123} \mathrm{Na}$ solicitação a Vargas, Leão Velloso menciona o brilhantismo de Cortesão ao realizar o curso de História da Cartografia no Itamaraty; a visita oficial que fez em 1922 ao Brasil, de quem é "um velho e meritório amigo"; e a sua disposição em servir militarmente na Segunda Guerra pelo Brasil como títulos que

\footnotetext{
121 José Carlos Reis (2007) tece um interessante panorama sobre os posicionamentos frente à colonização portuguesa do Brasil, identificando autores que redescobriam o Brasil e autores que faziam o elogio da ação portuguesa. Enquanto no primeiro grupo estavam autores como Capistrano de Abreu e Sérgio Buarque de Holanda, no segundo estavam Varnhagen e Gilberto Freyre. Analisando a circulação de Cortesão no Brasil, é possível dizer que o historiador transitou entre ambas, embora pendesse para o elogio da colonização. Retomarei esse ponto no capítulo final.

${ }^{122}$ CORTESÃO, J. Op. cit., 1991, p. 62.

${ }^{123}$ Disponível no sítio do MRE: <http://www.itamaraty.gov.br/cerimonial/condecoracoes/ordemnacional-do-cruzeiro-do-sul/regulamento>. Acesso em 14 nov. 2014.
} 
atestariam a pertinência da honraria. Deferido o pedido, o diploma foi expedido em 23 de novembro em $1944 .^{124}$

Além de ter recebido o título de Cidadão Benemérito de São Paulo, como reconhecimento pelos serviços prestados na organização da Exposição de História de São Paulo, Cortesão também reconhecido como sócio do Instituto Histórico e Geográfico Brasileiro e do de São Paulo. Ao lado do Itamaraty e a Academia Brasileira de Letras, o IHGB e as suas correlatas associações estaduais ainda eram os principais circuitos da vida letrada e do fazer historiográfico do país. ${ }^{125} \mathrm{O}$ reconhecimento a Cortesão, porém, não se restringiu a essas instâncias do campo intelectual brasileiro: junto às novas forças que atuavam nesse cenário, as universidades passavam a se tornar o espaço da profissionalização intelectual e da especialização dos saberes.

Nesse aspecto, concluo destacando a notícia do falecimento de Cortesão na Revista de História da Faculdade de Filosofia, Ciências e Letras da Universidade de São Paulo. Para Miguel Palmeira (2007), dedicatórias, necrológios e outros textos em que se ressaltam os epítetos de um autor são importantes vestígios do reconhecimento pelos pares. Assim sendo, ao reconhecer Cortesão como "homem de letras", o historiador do IHGSP e colaborador na Exposição de História de São Paulo, Thomaz Oscar Marcondes de Souza distingue a multiplicidade da ação intelectual de Cortesão, destacando a sua formação no Direito, na Medicina, na política, na Grande Guerra. Souza chama a missão oficial portuguesa nas comemorações do centenário da independência do Brasil de "literária" e caracteriza o seu exílio europeu como frutífero em cursos e conferências em universidades francesas e espanholas, destacando a sua passagem pelo Centre International de Synthèse Scientifique. De sua ação no Brasil, menciona apenas a coordenação dos trabalhos da Exposição de História de São Paulo. Ao discorrer sobre os seus textos, Souza divide a fase das letras, de 1909 a 1922, quando o "erudito historiador português passou a se dedicar aos assuntos históricos".

Dedica dois longos parágrafos à Teoria geral dos descobrimentos portugueses, lançado em 1940 na ocasião do Congresso do Mundo Português e à Carta de Pero Vaz

\footnotetext{
${ }^{124}$ Velloso, P. L. Correspondência ao Pres. Getúlio Vargas. Ministério das Relações Exteriores, Rio de Janeiro, 21 nov. 1944. Cópia. BNP/ACPC E25/1092-1093; BRASIL. PRESIDÊNCIA DA REPÚBLICA. Diploma da Ordem do Cruzeiro do Sul. Rio de Janeiro, 23 nov. 1944. BNP/ACPC E25/1164.

${ }^{125}$ A esse respeito, ver: GOMES, A. M. C. Op. cit., 1999 e FERREIRA, A. C. A epopeia bandeirante: letrados, instituições, invenção histórica (1870-1940). São Paulo: Ed. UNESP, 2002.
} 
de Caminha, publicado no Brasil em 1943. Citando alguns de seus títulos lançados no Brasil, menciona especialmente $A$ Fundação de São Paulo, capital geográfica do Brasil e Raposo Tavares e a Formação Territorial do Brasil. Conclui a notícia afirmando que o autor "se destacou como historiador, apesar de ter sido bastante contraditado tanto em Portugal como nos demais países, inclusive aqui no Brasil". Na ausência de documentos que apontem para as críticas sofridas pelo autor, fica a sugestão de que as sofridas no Brasil não eram tão relevantes se postas em perspectiva e diante de toda a sua trajetória, visualizada após a sua morte por um historiador brasileiro que trabalhou perto dele. ${ }^{126}$

Por fim, enquanto as honrarias, distinções e mesmo as biografias e análises da experiência brasileira de Cortesão dão ênfase às suas produções no âmbito do Itamaraty e da Biblioteca Nacional em torno da cartografia histórica, o texto de Thomaz Oscar Marcondes de Souza dá mais espaço às iniciativas do historiador em Portugal e em relação à historiografia paulista, seja por ter visto mais de perto essas ações, seja por dar mais importância a elas. Independentemente do que isso tenha sido, é inegável que a despeito de críticas - por ser estrangeiro e atuar em questões do interesse brasileiro ou por divergir dos critérios de análise de historiadores estabelecidos - Cortesão integrou-se plenamente à rede de intelectuais brasileira próxima ou distante das instâncias do Poder (sobretudo na mais próxima, visto que o Estado teve papel mais efetivo na sua legitimação do que os seus pares) deixando uma contribuição relevante ao estudo da história do Brasil por meio da cartografia histórica, documentação que é estruturante de um ponto de vista que articula geografia, história, diplomacia e também a visualidade.

Vendo-se a serviço da história do Brasil, exercendo assim "uma das melhores formas de ser português" ${ }^{127}$, o historiador aliava as suas concepções da história, fortemente marcada pelo fator geográfico às políticas territoriais e culturais do Brasil que não se esgotam na chamada Era Vargas. Marchando para o Oeste e buscando integrar no espaço e nas mentes a sua população heterogênea, o país instrumentalizava o conhecimento para dar um novo sentido à nação.

\footnotetext{
${ }^{126}$ SouzA, T. O. M. Jaime Cortesão (1884-1960). In: Revista de História. São Paulo, n. 44, out.-dez. 1960 , p. $570-572$.

${ }^{127}$ CORTESÃO, J. A fundação de São Paulo: capital geográfica do Brasil. Rio de Janeiro: Livros de Portugal, 1955 , p. 17.
} 


\section{CAPÍtulo 2.}

\section{Percursos da escrita histórica: a narrativa da conquista do sertão, dentro e}

\section{fora de uma oca}

\section{Cortesão, o sertão e os caminhos da construção de uma nação}

Categoria espacial, categoria de pensamento social, categoria cultural. Construída durante a colonização, a categoria sertão é usada desde muito antes da chegada dos portugueses à América. Janaína Amado traça o percurso dessa construção, que "talvez desde o século XII, com certeza desde o XIV", foi utilizada pelos portugueses "para referir-se a áreas situadas dentro de Portugal, porém distantes de Lisboa". Do século de Quatrocentos em diante, passou a "nomear espaços vastos, interiores, situados dentro das possessões recém conquistadas ou contíguos a elas, sobre os quais pouco ou nada sabiam". ${ }^{128}$ De acordo com a historiadora, poucas categorias têm sido tão importantes em termos de senso comum, pensamento social e imaginário para falar sobre uma ou mais regiões como a de sertão, sendo usada em diversos cantos do Brasil como referência a diferentes espaços. Entre 1870 e 1940, a categoria chegou a ser "absolutamente essencial (mesmo quando rejeitada) em todas as construções historiográficas que tinham como tema básico a nação brasileira". ${ }^{129}$

Como discutido no capítulo anterior, no esforço de construir a nação, o conhecimento histórico e geográfico foi demandado. Um dos principais destinos dos viajantes de fins do XVIII e inícios do XIX, o Brasil viabilizava a realização dos sonhos enciclopedistas da cultura iluminista. A política externa das monarquias europeias daqueles tempos "inscrevia-se num movimento mais amplo de constituição de conhecimentos mais positivos acerca de outros povos e civilizações", conhecimentos que se assentariam em bases seguras se os viajantes - naturalistas, botânicos, entre outros - pudessem pesquisar in loco os espaços em questão. A falta de história vista nas sociedades extra-europeias, consequência da ausência de escrita ou de monumentos,

\footnotetext{
${ }^{128}$ AMADO, J. Região, Sertão, Nação. In: Estudos Históricos, Rio de Janeiro, v. 8, n. 15, 1995, p. 147. Sobre "sertão" em Portugal, a autora cita CORTESÃO, J. Os descobrimentos portugueses. v. 1. Lisboa: Arcádia, 1958, p. 28.

${ }^{129}$ AmADO, J. Op. cit., 1995, p. 145-146.
} 
justificava a interpretação desses grupos e territórios tendo como ponto de partida a investigação da natureza. Karl Friedrich von Martius, botânico bávaro, esteve em viagem pelo Brasil entre 1817 e 1820. Sua obra, Reise in Brasilien, teve de esperar um século para ter sua tradução integralmente publicada, patrocinada pelo Instituto Histórico e Geográfico Brasileiro no ano de 1938. ${ }^{130}$

Von Martius era sócio-correspondente do IHGB e foi premiado pelo Instituto em 1847 pelo trabalho Como se deve escrever a história do Brasil, inscrito no concurso homônimo lançado pelo organismo que, sob os auspícios do imperador D. Pedro II, deveria lançar as linhas mestras para a construção do corpo e da alma da nação: sua geografia e a sua história. O trabalho de von Martius definiu que a base da escrita da história do Brasil deveria ter por base a sua especificidade enquanto nação, que estava expressa pela coexistência de três raças, que capitaneadas pela branca/europeia/portuguesa, ordenariam a construção da nação. ${ }^{131}$

Como as viagens eram a base para a produção dos saberes sobre as gentes e a natureza do país, diversas expedições partiram para os sertões do Brasil. Além de se baterem na resolução do problema indígena, que não se enquadrava no modelo de nação com alicerces europeus que se pretendia construir, transitando entre assimilação e aniquilação dos povos nativos, os homens envolvidos nesse gênero de atividade também pretendiam, com o reconhecimento do território, explorá-lo em suas possibilidades. ${ }^{132}$ João da Silva Machado, o Barão de Antonina, liderou nove expedições de exploração e reconhecimento dos sertões meridionais do Brasil, com vistas a estabelecer a comunicação fluvial entre Curitiba e Cuiabá entre 1844 e 1857. Membro do IHGB, o Barão fez registrar todas as suas expedições, minuciosamente relatadas pelo sertanista mineiro Joaquim Francisco Lopes, para em seguida publicar na Revista do Instituto. ${ }^{133}$

Essas atividades, ainda de acordo com o texto de Maria Cristina Cortez Wissenbach, construíam

\footnotetext{
${ }^{130}$ GUIMARÃES, M. L. S. História e Natureza em von Martius: esquadrinhando o Brasil para produzir a nação. In: História, Ciências, Saúde - Manguinhos, v. 7, n. 2, jul.-out. 2000.

${ }^{131}$ MARTIUS, K. F. von. Como se deve escrever a história do Brasil. $3^{a}$ ed. Rio de Janeiro: Instituto Histórico e Geográfico Brasileiro, 1991. (Coleção Capistrano de Abreu, v. 1).

${ }^{132}$ Guimarães, M. L. S. Op. cit., 1988; MonteIro, J. M. Tupis, Tapuias e Historiadores: estudos de história indígena e do indigenismo. Tese (Livre docência), Instituto de Filosofia e Ciências Humanas, Universidade Estadual de Campinas, Campinas, 2001. Retomarei essa discussão no capítulo final.

${ }^{133}$ WISSENBACH, M. C. C. Desbravamento e catequese na construção da nacionalidade brasileira: as expedições do Barão de Antonina no Brasil meridional. In: Revista Brasileira de História, São Paulo, v. 15, n. 30, 1995.
} 
[a] imagem de nação jovem, porém plena de possibilidades e energias, [que] encontrava sua melhor expressão na descrição de uma natureza virgem, generosa e portadora de mananciais inexauríveis, no dizer de Elliott [da expedição do Barão de Antonina]. Nada melhor para a visualização das potencialidades da pátria do que as descrições acerca da diversidade da flora e da fauna e da sucessão de formações geográficas - chapadões, campos, florestas, serras e picos - que desenhavam a paisagem do interior. Aliado a isso, a via de penetração através de uma multiplicidade de rios que, encadeados nas grandes bacias, serpenteavam em direção ao interior, demonstravam a tendência natural de conquista e enunciava também um conteúdo simbólico adicional. Trata-se, em geral, de uma concepção de narrativa e de recurso estilístico compartilhados por inúmeros outros relatos do século XIX e, neste sentido, presente também nos relatórios oficiais e nas obras literárias. ${ }^{134}$

Além das possibilidades diversas que a natureza exuberante e plena de riquezas inexauríveis, a própria natureza também era vista como quem dava o sentido da ocupação humana, a tendência natural de conquista rumo ao oeste. Retomando o raciocínio de Janaína Amado à luz da análise que faz Maria Cristina Cortez Wissenbach da expedição do Barão de Antonina, é possível entender a influência que os sertões exerciam sobre a mentalidade e sobre as práticas dos sujeitos imbuídos da missão de construir geográfica e historicamente o Brasil. Segundo Amado, o tema orientou o pensamento de historiadores do IHGB e outros identificados com a historiografia que produzia, como Varnhagen, Capistrano de Abreu e Oliveira Viana. Outros ainda trabalharam com o conceito de diferentes formas, como Euclides da Cunha, Nelson Weneck Sodré, Sérgio Buarque de Holanda e Cassiano Ricardo. ${ }^{135}$

Conforme foi exposto no capítulo anterior, a década de 1930 e o Estado Novo significaram redefinições não somente políticas e econômicas como também culturais e intelectuais, num contexto de nacionalismo intenso. No panorama da redefinição do saber histórico e mesmo da cultura histórica, conforme trabalhou Ângela de Castro Gomes, houve também uma transformação em relação às fontes e à interpretação. As fontes que guardavam o passado que se elegia como expressão da nacionalidade naquele momento estavam identificadas nas chamadas "tradições populares" do país: foi estabelecido assim um vínculo "entre uma certa noção de fonte e um certo tipo de tradição, que é cultural e popular", distinguido de outras tradições classificadas como de "elite" ou de "massa". No contexto da revista Cultura Política, veículo que que acabava por expressar um discurso oficial ou oficializado do

\footnotetext{
${ }^{134}$ WissenBACH, M. C. C. Op. cit., 1995, p. 142. Grifos meus.

${ }^{135}$ AMADO, J. Op. cit., 1995, p. 146.
} 
regime Vargas, o sentido de tradição ora qualificado converge com outra categoria amplamente utilizada, a de "espírito nacional", que também é polifônico. Essa categoria atua enquanto uma diretriz, uma referência ao que seria "fundamental de uma nacionalidade", uma "construção coletiva, identificada por intérpretes competentes e especializados". ${ }^{136}$ Nesse aspecto, a intelectualidade escolhida para interpretar e expressar esse espirito era aquela que vinha se batendo na construção de uma estética nacional: os modernistas. ${ }^{137}$

Seguindo a reflexão de Mônica Pimenta Velloso, é importante que se caracterizem os espaços e discursos do modernismo em tempos de Estado Novo, considerando não somente esta como uma das muitas forças que atuam naquele contexto como também se compreenda o papel do regionalismo paulista frente ao nacionalismo. Para a autora, a cidade de São Paulo, marcada pela cafeicultura, pela imigração, pela industrialização, pelas ferrovias, pela formação de um proletariado urbano havia se tornado um "centro febricitante", capaz de "difundir o moderno pensamento brasileiro". O fluxo da vida moderna, num clima de intensa agitação social, política e intelectual é o mesmo que é expressado pelo movimento modernista. Desde aquele tempo, o país vivia um momento otimista, apesar da decadência europeia do pós-Primeira Guerra. No novo tempo que se vislumbrava, São Paulo, "vivendo ainda um intenso desenvolvimento econômico, assume um lugar de vanguarda no conjunto nacional, podendo vivenciar intensamente tal clima". ${ }^{138}$

No chamado segundo tempo do movimento modernista, de 1924 em diante, as diferenças entre os grupos se acentuaram. Uma vez unidas as forças pela atualização da cultura brasileira, por meio da luta contra aquilo que era considerado ultrapassado, outros problemas se punham. Ainda que houvesse convergência na ideia de que o ingresso na modernidade deveria ser mediado pelo nacional, muito se divergia sobre a forma como se daria conta do nacional. Ao longo dos anos que se seguiram, com o Manifesto regionalista do Nordeste e com o acirramento dos

\footnotetext{
${ }^{136}$ GOMES, A. M. C. Op. cit., 1999, p. 161-162.

${ }^{137}$ A esse respeito, ver CAVALCANTI, L. Modernistas, arquitetura e patrimônio. In: PANDOLFI, D. (org.). Op. cit., 1999; BomenY, H. (org.). Op. cit., 2001; AndRADE, Mário de. O Turista Aprendiz. Estabelecimento do texto, introdução e notas por Telê Ancona Lopez. São Paulo: Duas Cidades/ Secretaria da Cultura, Ciência e Tecnologia, 1976.

${ }^{138}$ VeLLOSO, M. P. A brasilidade Verde-Amarela: nacionalismo e regionalismo paulista. In: Estudos Históricos, Rio de Janeiro, v. 6, n. 11, 1993, p. 92. Sobre esse mesmo contexto, é bastante profícuo o estudo de SEVCENKO, N. Orfeu extático na metrópole: São Paulo, sociedade e cultura nos frementes anos 20. São Paulo: Companhia das Letras, 1992.
} 
debates em torno do regionalismo, do nacionalismo e do cosmopolitismo, acentuaram-se as divergências entre os grupos. $\mathrm{O}$ grupo Verde-Amarelo, encampando parte da crítica feita pelos intelectuais do Nordeste à hegemonia do modelo de vida urbano-citadino, condenava aquilo que chamava de modismos estrangeiros, com os quais outros grupos estariam comprometidos. As diferenças entre as regiões do país passaram a ser vistas enquanto "partes de uma totalidade corporificada pela nação", urgindo a busca de singularidades que informam o conjunto, e, a partir dessa desgeografização, como propunha Mário de Andrade para solucionar o impasse, seria possível identificar a unidade, uma forma de dar sentido ao regionalismo. ${ }^{139}$

É nesse ponto que se inseriu o manifesto Nhengaçu, dos Verde-Amarelos: nele, a rememoração do período colonial elegia o momento áureo da civilização brasileira, "devido à integração pacífica entre o elemento colonizado e o colonizador". Caracterizava-se uma brasilidade isenta de conflitos, regida pela integração e pela harmonia. O tupi, passivo, absorvia étnica e culturalmente os portugueses, cuja chegada inaugurava um tempo que era entendido como não esgotado na colonização, permanecendo ao longo da história do país. Considerando a tradição como um valor que extrapola o contexto histórico, os Verde-Amarelos propõem um retorno necessário ao mito das origens, que revivido permitiria recuperar a brasilidade. Centrando-se no espaço, a elaboração do grupo caracterizava São Paulo e a aventura histórico-geográfica do bandeirismo como o lugar do mito. O herói, entre tantos outros a realizar a epopeia bandeirante, está encarnado no Martim Cererê de Cassiano Ricardo. ${ }^{140}$ Ricardo, que viria tempos depois a coordenar o jornal estadonovista $A$ Manhã, indicava alguns dos caminhos que seriam tomados também pela política cultural oficial.

Seguindo percurso semelhante de análise, Ângela de Castro Gomes visualiza as metáforas do movimento bandeirante a partir da política cultural do Estado Novo. O movimento em questão se dá sobre o território cultural, em vias de integração e definição de identidade: o discurso oficial do regime se apropria do símbolo paulista, ainda que seja, no fim das contas, construído por diversos intelectuais egressos do

\footnotetext{
${ }^{139}$ Velloso, M. P. Op. cit., 1993, p. 96-97.

${ }^{140}$ VeLloso, M. P. Op. cit., 1993, p. 99.
} 
modernismo paulista como o próprio Cassiano Ricardo, além de outras forças por vezes antagônicas. De acordo com a autora,

[s]e a história do Brasil fora até então marcada por uma narrativa que enfatizava a ocupação do espaço físico, chegara a hora de afirmar que o "meio", por si só, não marcava a fisionomia profunda das tradições de um povo. Tais tradições - definidas como a história realizada por nossos "maiores" e também pelos "homens comuns" - comportavam outras variáveis essenciais, entre as quais vale a pena atentar para as categorias de tempo/cronologia e de raça/cultura. ${ }^{141}$

No trabalho de pesquisar e interpretar o folclore brasileiro, os mitógrafos são caracterizados na revista Cultura Politica como "ressurreicionistas do bandeirismo", aludindo assim "ao alargamento das fronteiras culturais do país", em um processo que permite incorporar a "vivaz inteligência" do povo. Dos sertões do presente emergem os sertanejos, sujeitos "do interior do país", afastados "física e culturalmente das influências maculadas das cidades" e há tempos vistos como guardiães da memória e das tradições nacionais. O morador do litoral, especialmente aquele das pequenas cidades e vilas, também era qualificado como "guardião de um tipo de memória ancestral de nossas mais longínquas tradições", uma vez que o colonizador tinha chegado pelas praias. Ao lado das iniciativas de pesquisa recorrentes, voltadas para o tempo presente das sociedades qualificadas como guardiãs do tradicional e do popular, houve uma série de iniciativas governamentais empenhadas em tornar públicos manuscritos e fontes da Biblioteca Nacional, fomentando assim o trabalho dos historiadores e diminuindo as dificuldades para a realização de seu ofício. ${ }^{142}$

Dando especial destaque ao que vimos até o momento sobre os esforços dedicados às políticas de integração territorial; defesa e ocupação de fronteiras; caracterização da população por meio da geografia e da estatística; recolha e divulgação das tradições populares; renovação dos estudos históricos, entre outros, podemos visualizar a forma como se articulavam as frentes de trabalho na Era Vargas. O sertão era a chave fundamental para a construção de uma nação com base em si mesma, partindo da ideia de que os guardiães de seu espirito nacional eram as suas populações sertanejas, ainda que no litoral houvesse focos preservados do contato com outras forças que pudessem descaracterizá-lo de alguma forma.

\footnotetext{
${ }^{141}$ GoMes, A. M. C. Op. cit., 1999, p. 164.

${ }^{142}$ GoMeS, A. M. C. Op. cit., 1999, p. 166-168; 181.
} 
Como parte dos esforços que viabilizariam uma escrita da longa história da conquista do sertão sul-americano e do processo de desenho das linhas do mapa do Brasil, a organização dos Manuscritos da Coleção De Angelis, guardados na Biblioteca Nacional, teria grande impacto na historiografia de bandeirantes e de jesuítas - e também de índios - sobretudo nas zonas de fronteira entre o Brasil e os seus vizinhos, nomeadamente Uruguai, Paraguai e Argentina. Jaime Cortesão, a serviço da instituição, organizou e escreveu as introduções e notas de seis dos sete volumes que foram publicados entre 1951 e 1970. José Honório Rodrigues, à época diretor da Divisão de Obras Raras e Publicações, além de apresentar o primeiro volume e a documentação, referenda os critérios utilizados ao longo dos trabalhos de Cortesão. $^{143}$

A Coleção Pedro de Angelis, composta por impressos e manuscritos, é uma das principais peças do acervo da Biblioteca Nacional. A sua aquisição contou com a interferência de José Maria da Silva Paranhos, o Visconde do Rio Branco. O governo brasileiro, na figura do próprio D. Pedro II, demonstrou o seu interesse na aquisição da Coleção, que também era de interesse do General Urquiza, presidente argentino. Sucedidas as negociações, em 9 de fevereiro de 1854 a documentação chegou ao Rio de Janeiro. Dedicada em sua maior parte à história da América, foi distribuída, classificada e inscrita nos catálogos da Biblioteca Nacional, fora as 120 duplicatas doadas ao IHGB. Os manuscritos relacionados às questões de limites e fronteiras foram enviados ao Ministério dos Negócios Estrangeiros. ${ }^{144}$

Isso quer dizer que entre a aquisição da documentação, de grande valor diplomático e histórico, e a sua publicação, cerca de um século se passou. Grande parte pertenceu ao Arquivo da Província de Jesus do Paraguai e muitos textos constituem títulos de fundação da maior parte dos povos das províncias do Rio Grande do Sul e de São Paulo. Ainda de acordo com Honório Rodrigues, "para a história da formação territorial e para os problemas de limites, a Coleção Pedro de Angelis é uma das principais fontes" sob a guarda da Biblioteca Nacional brasileira, sendo aproveitada de forma limitada para monografias e estudos. Com a publicação,

\footnotetext{
${ }^{143}$ Rodrigues, J. H. Explicação. In: CORTESÃo, J. Jesuitas e Bandeirantes no Guairá (1594-1640). Rio de Janeiro: Biblioteca Nacional/Divisão de Obras Raras e Publicações, 1951, p. 9. (Manuscritos da Coleção De Angelis, v. 1).

${ }^{144}$ RODRIGUES, J. H. Op. cit., 1951, p. 3-6. Um histórico da coleção e a descrição da sua importância para o estudo das bandeiras foi publicado na imprensa paulista por Cortesão, na série Introdução à História das Bandeiras. Cf. CORTESÃO, J. Introdução à história das bandeiras, III: a coleção De Angelis e a cartografia antiga do Brasil. In: O Estado de S. Paulo, São Paulo, 3 set. 1947, p. 6.
} 
o diretor da Divisão de Obras Raras esperava que os estudos relacionados ao bandeirismo e à formação territorial fossem alargados. Dessa forma, poderiam ser esclarecidos problemas de limites, mesmo os já resolvidos, porém pouco aclamados. A publicação era descrita como "serviço patriótico e de boa amizade internacional". ${ }^{145}$

Segundo Cortesão, Pedro de Angelis, florentino, foi um "jornalista político de combate e publicou e comentou documentos históricos sobre o Prata e as fronteiras de Argentina e Chile". Teve papel fundamental no desenvolvimento da imprensa argentina, na área da educação, no estudo de línguas indígenas. Tentava vender a sua coleção ressaltando o interesse que teria sobre a questão da posse de territórios fronteiriços, cruciais nas disputas travadas entre Argentina e Brasil, à época com relações bastante estremecidas. Atuando como agente secreto brasileiro no Uruguai, veio para o Brasil em 1853, sendo recebido com apreço no IHGB, instituição da qual era sócio-correspondente, em sessão presidida por D. Pedro II. ${ }^{146}$

Na escrita da introdução, Cortesão ressalta que "há uns seis anos", quando começou a estudar a Coleção, utilizou largamente muitos dos documentos inéditos nela existentes em suas lições dos cursos de História da Cartografia do Brasil e História da Formação Territorial do Brasil, entre 1945 e 1946 no Instituto Rio Branco. Rubens Borba de Morais, então diretor da Biblioteca Nacional brasileira, ouviu algumas daquelas lições, as que se referiam à história das bandeiras paulistas e a seus conflitos com os jesuítas espanhóis no Paraguai, e convidou Cortesão para completar o estudo da Coleção, com leituras suas dos documentos que mais de perto se referiam à história do Brasil. Josué Montelo, diretor no momento da publicação do primeiro volume, manteve o convite a Cortesão, que procedeu ao agrupamento da documentação para efeitos de publicação, reunindo-as temática e cronologicamente. ${ }^{147}$ Essas declarações de Cortesão apontam para a complementaridade entre as atividades que realizava nas duas instituições, a Biblioteca Nacional e o Instituto Rio Branco, bem como demonstram a necessidade do envolvimento institucional em um empreendimento de grande vulto, que ainda assim levou cerca de duas décadas para ser integralmente publicado.

\footnotetext{
${ }^{145}$ RODRIGUES, J. H. Op. cit., 1951, p. 7-8.

${ }^{146}$ CORTESÃO, J. Op. cit., 1951, p. 14; 36; 40. Pedro de Angelis demonstrava apreço ao monarca brasileiro, produzindo textos e defendendo os interesses do império brasileiro sobre o Prata e o Amazonas, este sob o olhar dos Estados Unidos.

${ }^{147}$ CORTESÃO, J. Op. cit., 1951, p. 61.
} 
Ainda que tratando de uma história da qual fariam parte três grandes grupos: os bandeirantes luso-brasileiros, os jesuítas castelhanos e os diversos povos indígenas, o título da maior parte dos volumes da Coleção traz apenas "Jesuítas e Bandeirantes", sugerindo assim a sua agência histórica como hegemônica nas relações desse universo colonial. Além disso, o conjunto de introduções e de documentos publicados delineia um quadro dos "antecedentes" do Tratado de Madri, estudo que o autor desenvolvia junto ao Itamaraty e que era publicado em tomos a partir do ano de 1949. Ao lado de Alexandre de Gusmão e o Tratado de Madrid (1750), a organização e publicação dos Manuscritos da Coleção De Angelis representa o lugar de Cortesão nas principais questões colocadas como centrais pelas necessidades que criava o complexo programa para o país que teve início em 1930 e não se esgotou nos anos do Estado Novo. Um lugar que além de distinguir o intelectual estrangeiro, permitindo-lhe o contato com uma documentação de alto valor também para as relações internacionais, legitima a sua produção por meio da chancela de organismos-chave da produção de um conhecimento oficial: a Biblioteca Nacional e o Itamaraty. Cortesão torna-se um especialista nessas questões, publicando textos na imprensa, palestrando em diversos lugares do país e, ainda, organizando a exposição em comemoração ao aniversário de São Paulo, cidade intimamente ligada à chamada história da formação territorial do país.

Nanci Leonzo discute a produção do historiador a partir dos Manuscritos da Coleção De Angelis, subsidiária principal de toda a sua escrita, tanto no Itamaraty quanto fora dele. Algumas das leituras que Cortesão fez da documentação cartográfica foram ao encontro das concepções que o autor fazia do papel português ao longo do processo da expansão marítima, confirmando algumas de suas hipóteses iniciais. Ao comentar o trabalho de Cortesão, a historiadora diz que

[a] utilização da Coleção [D]e Angelis "como fonte subsidiária para o estudo da formação territorial do Brasil e da expressão cartográfica" permitiu-lhe confirmar a tese de que "portugueses e luso-brasileiros cedo tiveram a intuição da existência duma vasta unidade geográfica, econômica e humana, em oposição aos escassos limites impostos pelo Tratado de Tordesilhas, intuição essa que procuraram traduzir pelo mito geográfico duma Ilha-Brasil, cercada pelas bacias dos rios da Prata e do Amazonas". ${ }^{148}$

\footnotetext{
${ }^{148}$ LEONZO, N. Op. cit., 1984, p. 117; CORTESÃO, J. Introdução à História das Bandeiras. v. 1. Lisboa: Portugália, 1964, p. 31-39.
} 
O mito geográfico da Ilha-Brasil foi uma de suas linhas de investigação, associado à ideia de que cartógrafos portugueses teriam falseado a posição do meridiano de Tordesilhas para reclamar a sua posse sobre as terras americanas, fazendo-o coincidir com acidentes geográficos do interior do continente e justificando a existência de uma unidade geográfica e humana entre as bacias amazônica e platina, que seria amputada pela linha tal como pretendiam os castelhanos. Dessa forma, os domínios portugueses estariam compreendidos em uma unidade territorial. Diversos documentos atestariam, segundo Cortesão, a existência de uma grande lagoa a interconectar as bacias referidas, como as primeiras descrições geográficas, mapas e outros documentos cartográficos de Gaspar Viegas, Lopo Homem (1519), Diogo Ribeiro (1525-1527), André Homen (1559), Bartolomeu Velho (1561), como ressalta Íris Kantor. ${ }^{149}$

Embora Cortesão dissesse que se tratava de uma prática portuguesa, Maria Fernanda Alegria ${ }^{150}$ questiona o motivo pelo qual outros cartógrafos de então não teriam corrigido aquele erro, que perdurou até o século XVIII. Aquele mito geográfico possuía seus "antecedentes na cartografia medieval, no itinerário das viagens de São Brandão como uma das ilhas (afortunadas) que existiriam no Atlântico Norte" e que povoaram o imaginário europeu durante muito tempo após a chegada ao Novo Mundo. Uma dessas ilhas, de acordo com cartas do século XIV, chamava-se Brasil/Brazil e estaria próxima da Irlanda.${ }^{151} \mathrm{~A}$ ideia de que a América era a realização dessas ilhas foi superada totalmente apenas com a descoberta, por Bering, de um estreito a interligá-la ao continente asiático, em 1741.

Cortesão ainda sustentava que o mito poderia teria sido uma apropriação da cosmografia dos povos indígenas, que segundo o jesuíta Simão de Vasconcelos, transmitiam os conhecimentos geográficos do interior aos portugueses. Por outro lado, o historiador "reconheceu (...) que a expressão cartográfica do mito da ilha brasil é resultado de uma cartografia estatal dirigida", de acordo com a hipótese, hoje questionável, na qual insistia, da política do sigilo português sobre os descobrimentos. Sérgio Buarque de Holanda contestou, nas páginas da Folha da

\footnotetext{
${ }^{149}$ KANTOR, I. Usos diplomáticos da ilha-Brasil: polêmicas cartográficas e historiográficas. In: Varia Historia, Belo Horizonte, v. 23, n. 37, jan.-jun. 2007, p. 71.

${ }^{150}$ ALEGRIA, 1995 apud KANTOR, I., 2007.

${ }^{151}$ KANTOR (2007) cita o trabalho de Gustavo Barroso, O Brasil na lenda e na cartografia antiga, publicado em 1941, pela Companhia Editora Nacional. Nesse texto, Barroso menciona documentos cartográficos que apresentam uma "ilha-Brasil" e sustenta uma origem céltica deste mito a partir do posicionamento da ilha próxima à Irlanda.
} 
Manhã, a tese da Ilha Brasil, rebatendo sobretudo a ideia de "uma razão de Estado geográfica implícita" no movimento das Bandeiras, partindo de um pressuposto "programa expansionista" português pré-determinado. Ainda segundo a autora, de qualquer modo, a afirmativa da intencionalidade portuguesa a partir do uso da documentação cartográfica, para além do objetivo de sustentar as teses apresentadas sobre a diplomacia portuguesa, atesta para Cortesão a importância dessa documentação como instrumento jurídico na defesa das soberanias territoriais. ${ }^{152}$

Nas páginas de $A$ Manhã , no qual eram divulgadas as atividades de Cortesão, publicou-se o convite à participação em uma conferência a ser proferida pelo então professor do curso do Instituto Rio Branco. Na sede do Ministério da Educação, à noite daquele mesmo 12 de setembro de 1944, teria lugar a apresentação de $A$ Cartografia antiga e os fundamentos geográficos e pré-históricos da nação brasileira. ${ }^{153}$ Como o título indica, a conferência era um apanhado das bases territoriais sobre as quais teria se construído o Brasil. Na ocasião, o autor discorreu sobre os aspectos históricos e cartográficos do mito da ilha-Brasil e da relação entre as bandeiras e os limites constituídos após o Tratado de Madri. Concluía-se que a consolidação do território brasileiro tinha se dado a partir da fusão de conhecimentos ameríndios e portugueses.

Do ponto de vista de Cortesão, as cartografias quinhentista e seiscentista delineiam a gênese de um "embrião geográfico brasileiro". Na ocasião, o autor também falou sobre o que acreditava ser a origem indígena, ou mesmo lusoameríndia, do mito da ilha-Brasil. Lançando mão da divisão etnográfica feita pelo viajante francês Orbigny, que classificou os povos sul-americanos em três raças: andoperuana, pampeana e brasílio-guarani, Cortesão discute as unidades culturais $e$ geográficas do continente e a ideia de paraíso terrestre presente nos escritos do naturalista. $\mathrm{O}$ historiador ainda destacou um trecho em que Orbigny menciona os grandes deslocamentos pela terra e pelos rios. Complementando a explanação, Cortesão comenta a distribuição geográfica e linguística dos povos indígenas do subcontinente no mapa de Nordenskjöld, fazendo então referência ao Peabiru, caminho indígena então reconstituído por Washington Luís. ${ }^{154}$

\footnotetext{
${ }^{152}$ KANTOR, I. Op. cit., 2007, p. 74-76.

${ }^{153}$ In: A Manhã, Rio de Janeiro, 12 set. 1944, p. 6.

${ }^{154}$ CORTESÃo, J. A Cartografia antiga e os fundamentos geográficos e pré-históricos do Brasil. Conferência. Datil., 33 f., Rio de Janeiro, 12 set. 1944. BNP/ACPC E25/38. Cortesão ofertou ao historiador e político, como o fez a tantos outros, o volume de Jesuitas e Bandeirantes no Guairá. Em agradecimento, Washington Luís menciona a importância da documentação publicada para o "conhecimento da
} 
Ao afirmar que a unificação do território "brasileiro" obedeceu às "imposições duma individualidade geográfica, que a facilitaram extremamente", o faz munido da interpretação que coloca o índio como o "elemento da revelação geográfica", sendo a "terra e o seu primitivo habitante" a lógica das bandeiras. De acordo com essa conclusão, é possível visualizar o que Cortesão chamou de fundamentos geográficos e pré-históricos do Brasil: a terra e o seu segredo geográfico são revelados pelos índios, nesse sentido enquadrados como "pré-históricos". O conhecimento nativo sobre a terra, portanto, serve para abrir caminho para que um povo "criador de história" como o português possa enfim fundar um país. Tal era a contribuição indígena para a formação do território brasileiro.

Lendo a relação entre a terra sul-americana e o seu habitante como "a lógica das bandeiras", fundada no momento em que é "revelada" ao adventício a chamada unidade territorial, Cortesão caracteriza o bandeirismo como uma aventura que não se tinha se baseado apenas nos instintos bárbaros de presa, como diziam jesuítas e alguns historiadores. Colocando em segundo plano o apresamento e a escravização indígena, Cortesão qualifica as bandeiras, particularmente as paulistas, como reivindicações de um patrimônio geográfico, humano e cultural. O historiador compara Raposo Tavares a Fernão de Magalhães por fazer o "périplo platinoamazônico". Ainda que nem toda a zona de expansão alcançada por Tavares tenha se tornado parte do território brasileiro, isso por causa dos jesuítas castelhanos "inimigos desse grande movimento de unificação", Cortesão comemora o fato de Alexandre de Gusmão ter chegado a tempo de ser o "definidor genial" desse movimento, baseando-se na "ordem da geografia política, de defesa diplomática e de direito entre as nações". 155

A história das bandeiras era narrada, portanto, de um ponto de vista que apesar de mencionar uma fundamentação indígena, apresentava um embate entre portugueses e luso-brasileiros, especialmente paulistas, imbuídos numa tarefa de efetivar uma unidade que seria natural do continente, contra jesuítas castelhanos. As disputas entre portugueses e espanhóis na península eram visualizadas por Cortesão no espaço geográfico da América do Sul. Cortesão havia constituído uma escrita para a formação territorial do Brasil a partir de uma continuidade da expansão marítima

definição geográfica do sul do Brasil", assunto que o interessava "há anos". Luís, W. Correspondência a Jaime Cortesão. São Paulo, 7 abr. 1952. BNP/ACPC E25/607.

${ }^{155}$ CORTESÃO, J. Op. cit., 1944. 
portuguesa e da luta contra a Espanha filipina, visível no conjunto de sua obra e também na curadoria da Exposição de História, como interpreta Luiz Felipe de Alencastro. ${ }^{156}$

Capistrano de Abreu foi quem abriu o caminho para o estudo do Brasil a partir do interior. No início do século passado, o historiador cearense era um desbravador, revelando novas fontes e novas leituras sobre a história brasileira, mesmo que sua obra ficasse inacabada. ${ }^{157}$ Capitaneando a "redescoberta do Brasil", Capistrano delineia uma escrita em que o povo, as lutas, os costumes, a miscigenação, o clima tropical e a natureza são postos em evidência. O nacional é alçado à condição de sujeito de sua história, "que não deveria vir mais nem de cima e nem de fora, mas dele próprio". Do seu ponto de vista, o interior, indígena e mameluco, a partir de suas expressões culturais e sociais, traria os elementos mais singulares da identidade brasileira, contrapondo-se ao litoral, construído a partir de dois elementos exóticos: o português e o africano. ${ }^{158}$

Além do mais, Capistrano destaca no capítulo O Sertão o papel primordial de São Vicente e o estabelecimento de Piratininga na "borda do campo" como o início da história da conquista do sertão. O Tietê era o facilitador dos caminhos pelo interior, bastando seguir seu curso para alcançar a bacia do Prata. O Paraíba apontava o caminho para o norte. Os paulistas, lançando-se como bandeirantes, partiam para a caça e a escravização. ${ }^{159}$ Segundo Reis, para Capistrano a ação bandeirante já é da gente brasileira e não pertence à história portuguesa, gente que usa da brutalidade e da violência para com os povos indígenas e continua a "ação colonizadora e cristianizadora do português, e usando os mesmos métodos". ${ }^{160}$

Afonso Taunay, historiador paulista, foi um dos discípulos de Capistrano, que teria o indicado o caminho do estudo das bandeiras como importante e necessário. ${ }^{161}$ Ao proceder o trabalho com a documentação das expedições sertanistas, Cortesão se

\footnotetext{
${ }^{156}$ Alencastro, L. F. O trato dos viventes: formação do Brasil no Atlântico Sul. São Paulo: Companhia das Letras, 2000, p. 335.

${ }^{157}$ SOUZA, L. M. apud REIS, J. C. Op. cit., 2007, p. 94.

${ }^{158}$ REIS, J. C. Op. cit., 2007, p. 97; 99.

${ }^{159}$ ABReu, C. Capitulos de História Colonial. Rio de Janeiro: Biblioteca Nacional, s/d. Documento em formato digital disponível em $<$ http://objdigital.bn.br/Acervo_Digital/livros_eletronicos/capitulos_de_historia_colonia.pdf $>$, p. 56. Acesso em 28 jun. 2015.

${ }^{160}$ REIS, J. C. Op. cit., 2007, p. 105.

${ }^{161}$ ANHEZINI, K. Um metódico à brasileira: a escrita da história de Afonso de Taunay. In: Revista de História, São Paulo, n. 160, jan.-jun. 2009, p. 251.
} 
aproximou não somente de José Honório Rodrigues, diretor da divisão em que trabalhava na Biblioteca Nacional, como também se correspondeu com Taunay. A troca de missivas se refere à busca de documentos sobre Alexandre e Bartolomeu de Gusmão em Santos, mencionando hipóteses de Capistrano de Abreu sobre laços familiares do diplomata e do padre na cidade. Na ocasião, o autor menciona também o envio de volumes de sua História [Geral] das Bandeiras [Paulistas]. ${ }^{162}$ Tais laços com o historiador paulista sugerem quais foram os seus primeiros interlocutores de Cortesão sobre a história das bandeiras, dos bandeirantes e da formação territorial do Brasil em São Paulo, membros de um grupo que escrevia história local olhando para os próprios antepassados bandeirantes.

Reforçando, as atividades desempenhadas pelo historiador na Biblioteca Nacional e no Itamaraty foram complementares, uma vez que os documentos com os quais entrou em contato - grande parte deles organizada, transcrita e publicada sob sua coordenação, a pedido das instituições - foram articulados em torno da problemática da chamada formação territorial do Brasil. Segundo informa Maria Beatriz Nizza da Silva (1984; 1985), esses ambientes são centrais na produção brasileira de Cortesão e estão em relação com os arquivos portugueses com os quais o intelectual mantinha contato. Como foi possível notar, o objetivo das atividades com as quais Cortesão se envolveu vinha das políticas do Estado, seja sob o comando de Vargas, durante o Estado Novo ou depois de seu término em 1945. O fato é que em grande parte os resultados daqueles trabalhos deram a sua contribuição à conquista do interior do Brasil, tanto pelo passado quanto pelo presente.

\section{São Paulo, capital cultural: a cidade às vésperas de seu Quarto Centenário}

Afonso d'Escragnolle Taunay empenhou-se em fazer do Museu Paulista um baluarte da história de São Paulo e também do Brasil. Dedicou-se ao estudo da história pátria sobretudo a partir da chamada "conquista do Brasil pelos brasileiros", ideia que parte da concepção de Capistrano de Abreu, a quem podemos chamar de seu mestre. Debruçou-se sobre a vida na São Paulo desde os primeiros anos,

\footnotetext{
${ }^{162}$ TAUNAY, A. Correspondência a Jaime Cortesão. Bragança, 4 ago. 1949. BNP/ACPC E25/1067. Essa correspondência foi respondida em CORTESÃO, J. Correspondência a Afonso Taunay. Rio de Janeiro, 09 ago. 1949. Museu Paulista, ARQ 94.1, pasta 3.
} 
passando pelo papel de seus sertanistas na formação territorial do Brasil. De 1915 a 1954 publicou diversos estudos acerca das histórias paulista e paulistana, tornandose um dos mais expressivos historiadores dos primeiros decênios do século XX. ${ }^{163}$

Segundo Lidiane Soares Rodrigues (2011), Taunay foi escolhido para a área de História do Brasil quando da inauguração da Faculdade de Filosofia, Ciências e Letras, instituto da Universidade de São Paulo. Sua trajetória acadêmica teve início na Politécnica do Rio de Janeiro, onde se formou engenheiro em 1900, passando ainda pela Politécnica paulista. Anos depois, em 1917, tornou-se diretor do Museu Paulista, quando modificou a sua organização, dedicando-o à história de São Paulo. Atuando como catedrático de História Universal entre os beneditinos, tanto no Ginásio de São Bento quanto na sua Faculdade Livre de Filosofia e Letras, foi professor de Sérgio Buarque de Holanda e de Alfredo Ellis Júnior. ${ }^{164}$

Como disse, o fato de Cortesão construir a sua história da formação territorial do Brasil próximo de Taunay, não deixa de aproximá-lo da perspectiva histórica que este construiu, por sua vez, sob a influência de Capistrano de Abreu. Conforme apresentou José Carlos Reis, Capistrano antecipou muitas das discussões que se tornariam importantes nas décadas seguintes, além da centralidade que ocupou o interior em sua produção. Contrariava-se toda uma tradição que vinha se constituindo de elogio da colonização portuguesa. ${ }^{165}$ Essas relações são trazidas à discussão de modo a identificar as circulações e transformações pelas quais passou a historiografia brasileira desde a criação do IHGB e que reverberam nas escritas e leituras do passado expressas à época em que Cortesão esteve no Brasil, das quais, como já identificamos, ele toma parte enquanto produz história sob a chancela da Biblioteca Nacional e o Ministério das Relações Exteriores.

Alfredo Ellis Júnior substituiu seu antigo mestre na cátedra de História da Civilização Brasileira da FFCL-USP em 1939, ano em que Taunay passou a dedicarse integralmente ao Museu Paulista. Ellis Jr. era formado pela Faculdade de Direito, transitando entre advocacia, literatura, historiografia, biografia de grandes vultos e a história das bandeiras. Além disso, era membro da Academia Paulista de Letras e do IHGSP - e deputado estadual em 1925 e em 1934. Um "exemplar típico" de

\footnotetext{
${ }^{163}$ ANHEZINI, K. Op. cit., 2009, p. 222-223.

${ }^{164}$ RODRIGUES, L. S. A produção social do marxismo universitário em São Paulo: mestres, discípulos e "um seminário" (1958-1978). Tese (Doutorado em História Social), Faculdade de Filosofia, Letras e Ciências Humanas, Universidade de São Paulo, São Paulo, 2011, p. 267.

${ }^{165}$ REIS, J. C. Op. cit., 2007, p. 97.
} 
"historiador dos institutos", defendeu, para assumir a cadeira, Meio século de Bandeirantismo, 1590-1640. ${ }^{166}$

Lidiane Rodrigues fez um balanço entre estes dois sujeitos, cujas trajetórias trazem à cena fatores que concorrem para o entendimento das dinâmicas das relações intelectuais locais:

Taunay e Ellis Jr. eram eruditos, ligados à produção anterior ao sistema universitário, radicavam-se, de modos distintos, nos ensinamentos de Capistrano de Abreu. Trata-se de historiadores de transição, entre os tempos dos "eruditos/autodidatas", e a chegada da "vez dos profissionais do saber específico, pesquisadores e professores formados nos quadros universitários". A divisa profissionais/polígrafos tem sua validade nesses casos - desde que, matizada, pelo reconhecimento do laborioso empenho na construção institucional de arquivos e museus a que se dedicaram - indispensáveis ao métier, pré ou pós universitário. Estas constatações reafirmam processos similares em diversas áreas. Há, contudo, uma peculiaridade a se realçar. Taunay e Ellis Jr. não se vincularam apenas à historiografia brasileira, mas, pela presença de seus familiares nas elites políticas, à história do Brasil. E este vínculo foi a condicionante mais básica da produção edificante e algo heroica dela. ${ }^{167}$

De acordo com Rodrigues, a história como acontecimento e a história como área de conhecimento eram inseparáveis do ponto de vista dos historiadores que antecederam a história enquanto disciplina universitária no Brasil. No Largo São Francisco, alunos e professores direcionavam suas energias sem diferenciar estudos históricos e possibilidades de intervenção nos rumos históricos. A autora parte de uma reflexão de Maria Helena Bueno Trigo para ler as relações dentro e fora das Arcadas, sobretudo entre elas e os historiadores do IHGSP, que ao colocar-se (os paulistas de quatrocentos anos) como agentes históricos imprescindíveis, confirmam a ideia difundida de que o grupo dominante é o que faz a história. ${ }^{168}$

\footnotetext{
${ }^{166}$ RoDRiguES, L. S. Op. cit., 2011, p. 271.

${ }^{167}$ RODRIGUES, L. S. Op. cit., 2011, p. 272. O fazer história está diretamente ligado ao fato de muitos dos alunos/professores da Universidade de São Paulo terem sido combatentes em 1932. Sobre isso, Lidiane Rodrigues traz uma declaração feita por Braudel: "Se, ao se matricularem na jovem instituição pactuavam, como lhes era possível, do projeto da 'comunhão paulista' e da resposta política que ela propunha para a derrota de 1932 - vale dizer, ao escolherem a seção de História e Geografia, davam prosseguimento, a seu modo, àquela tradição na qual são indiferenciados os papéis de estudar, escrever efazer história. A história os derrotara, mas a ela e a São Paulo dedicariam seus melhores esforços" (apud RODRIGUES, 2011, p. 274). Também segundo a autora, a Faculdade de Direito, de onde vinham esses sujeitos, tinha funcionado como um verdadeiro centro de recrutamento para a revolta de 1932, além de historicamente ter se engajado em questões políticas nacionais, como o abolicionismo e o republicanismo, fazendo parte dos quadros políticos do Império e da República e fundando o Partido Democrático. Depois de 1930, opôs-se a Vargas, aliando-se ao PD e ao diário $O$ Estado de S. Paulo (RODRIGUES, 2011, p. 276).

${ }^{168}$ RoDRIGUES, L. S. Op. cit., 2011, p. 278.
} 
Ainda que tenha se estabelecido no Rio de Janeiro, a capital do país, a primeira conferência realizada por Cortesão, em 1940, foi na cidade de São Paulo. No auditório sede d' $A$ Gazeta, o autor falou sobre $A$ Certidão de Nascimento do Brasile do Novo Mundo, sobre um documento de 1503, relativo aos resultados da viagem de Cabral, registrado em cartório. Estando em São Paulo, o historiador encontrou o ensejo para exaltar a cidade, a "primeira escalada de gigantes", do mar ao planalto, bem como a instalação da "consciência cristã sublime de Portugal na América" representada pela criação de um colégio jesuítico. Para Cortesão, a "metrópole dos bandeirantes" figura como uma "reencarnação do espírito lusíada dos Descobrimentos, coração do sertanismo épico, cujas pulsações golfaram sobre o imenso território e até aos seus confins, por torrentes, o sangue luso-brasileiro, que unificou a Pátria Nova (...)”. Dos jesuítas, passando pelos bandeirantes, Cortesão chega por fim ao "coração da independência", que teria marcado a "face do Brasil contemporâneo".

O conferencista justificou a escolha do tema, sobre o documento que considera a "certidão de nascimento" do Brasil, pelo fato dela ser proferida em uma das cidades mais representativas dessa gênese. Diz o historiador que deseja marcar a participação portuguesa na "epopeia bandeirante", reivindicada como somente brasileira e paulista, especialmente pelos "brasileiros de São Paulo". Seu ponto de vista foi argumentado pela afirmação de que

(...) uma das maiores glórias portuguesas, foi a de haver suscitado, antes que nenhum outro povo colonizador a formação duma raça euro-americana, duma cultura euro-americana e do foco de mais vasta e continuada difusão de cultura europeia, que jamais povo algum criou em mundos novos.

Referindo-se a uma conversa, Cortesão se lembra de uma questão que havia posto a um interlocutor (que não identifica): “- Não bastara (...) a Portugal a glória de haver suscitado a formação desse foco de expansão cultural?". À resposta positiva, o interlocutor questionou Cortesão de qual teria sido, então, esse foco. Explicando aos que o assistiam, o historiador declarou qual tinha sido a sua resposta: o foco de irradiação "sem par" é o estado de São Paulo "e a sua expressão heroica, tão lusitana como brasileira, os bandeirantes". ${ }^{169}$ As palavras de Cortesão nessa ocasião, quando ainda estava se ambientando ao novo país, demonstram certa dose de ousadia, e ${ }_{169}$ CORTESÃo, J. A Certidão de Nascimento do Brasil e do Novo Mundo. Conferência. São Paulo, 1940.
BNP/ACPC E25/40. 
permitem identificar as discordâncias entre ele e os "brasileiros de São Paulo" que menciona, certamente outros historiadores. Retomaremos essas divergências, refletindo sobre o impacto que ela pode ter tido sobre a sua recepção na terra piratiningana, em breve.

No momento em que Cortesão chegava ao Brasil, a dinâmica da produção intelectual se transformava na capital paulista. A Faculdade de Filosofia, Ciências e Letras da Universidade de São Paulo, como já vimos antes, causava impacto nos círculos intelectuais locais, sobretudo pela influência significativa que exerciam os professores estrangeiros que haviam sido contratados para formar os primeiros quadros da instituição. Ao analisar a geração de intelectuais que se reuniu em torno da revista Clima, primeira iniciativa que partia do interior da Faculdade de Filosofia, Heloisa Pontes apresenta o processo de renovação da tradição ensaística da crítica brasileira, marcada a partir de então pelo rigor científico. O grupo se diferenciava dos seus antecessores tanto por não atuar concomitantemente na literatura e na doutrina política quanto por demarcar suas posições em relação aos modernistas e aos outros cientistas sociais com os quais tiveram contato no ambiente da universidade. ${ }^{170}$

A reflexão encaminhada pela autora permite compreender as dinâmicas do universo intelectual, cultural e da produção do conhecimento na cidade de São Paulo entre as décadas de 1940 e 1960, período em que Cortesão esteve em íntimo contato com os circuitos locais e em que as comemorações dos quatrocentos anos da fundação da cidade, em 1954, produziram diversos sentidos para a cidade que se tornava a mais populosa do país. Tal panorama, como não poderia deixar de ser, é marcado pela efervescência em termos de produção artística e intelectual no país em tempos de Estado Novo.

Segundo a autora, o grupo de intelectuais, artistas e arquitetos que gravitava em torno de Rodrigo de Mello Franco de Andrade, diretor do Serviço do Patrimônio Histórico e Artístico Nacional (SPHAN), organismo criado em 1937, "procurou delimitar a sua modernidade na literatura, nas artes e na política por meio da recuperação do passado colonial brasileiro". Nesse sentido, o barroco e a arte/arquitetura moderna eram vistos como pares complementares, "sinais simbólicos de uma continuidade pretendida pelos artífices da política cultural

\footnotetext{
${ }^{170}$ PonTeS, H. Destinos mistos: os críticos do grupo Clima em São Paulo (1940-1968). São Paulo: Companhia das Letras, 1998, p. 13-14.
} 
brasileira". Nesse aspecto, Minas Gerais torna-se referência da brasilidade na arte, na arquitetura e no patrimônio coloniais. ${ }^{171}$

Em 1938, o francês Roger Bastide chega à Universidade de São Paulo e impressiona os alunos Antonio Candido, Décio de Almeida Prado e Ruy Coelho por seu contato com Mário de Andrade, o barroco e a produção artística colonial. Os alunos eram assim estimulados a descobrir "o que se produzia sobre o Brasil", visitando igrejas coloniais no entorno da capital ou a fazendo a leitura de fotografias do Serviço do Patrimônio Histórico. Como menciona a autora, os integrantes do grupo de amigos diziam que os professores estrangeiros "direcionavam o olhar dos alunos para dentro do Brasil". ${ }^{172}$

O grande número de sujeitos que circulavam no entorno de Rodrigo de Mello Franco de Andrade, formado pelos críticos que vinham da Faculdade de Filosofia da USP, pelos artífices do movimento modernista, por intelectuais, artistas, arquitetos, acabava por forjar um ideário modernista. Tal ideário, que norteou a política cultural do SPHAN, se sustentava sobre um tripé que tinha Minas, São Paulo e a França como bases. Por sua vez, essas mesmas bases asseguraram a tradição do modernismo e garantiram a sua posição nos sistemas intelectual, artístico e cultural brasileiro.

Segundo Pontes, pode-se falar em hegemonia dessa tradição no caso paulista, em se considerando que toda a história intelectual e cultural de São Paulo foi construída em torno das interpretações e da posição de destaque que ocuparam os seus "atualizadores" no sistema de produção cultural entre as décadas de 1930 e 1950. Tal sistema é identificado pela autora na rede formada pela Faculdade de Filosofia; pela imprensa (particularmente na Folha da Manhã e n'O Estado de S. Paulo); pelo Departamento de Cultura ${ }^{173}$; pelo Museu de Arte Moderna ${ }^{174}$; por revistas como

\footnotetext{
171 Pontes, H. Op. cit., 1998, p. 25.

172 PonTes, H. Op. cit., 1998, p. 30-32.

${ }^{173}$ O Departamento de Cultura da cidade de São Paulo, criado em 1935, teve como primeiro dirigente Mário de Andrade. O escritor saiu da direção do órgão em razão do golpe de 1937, partindo então para o Rio de Janeiro. Na capital federal, o intelectual lecionou na Universidade do Distrito Federal, fechada pelo aparato repressivo do Estado Novo em 1939. Ainda no Rio, Mário de Andrade trabalhou junto ao programa cultural do Estado Novo junto ao Ministério da Educação de Gustavo Capanema, além de servir ao Instituto Nacional do Livro e ao SPHAN. Mesmo assim, o escritor não deixou de criticar os intelectuais que aderiram integralmente ao programa governamental, ainda que sob alegações financeiras. Apesar de ressaltar as qualidades de sua geração, Mário criticava o fato de estarem aquém do que poderiam fazer em inícios da década de 1940, depositando as suas esperanças na geração dos "moços da Faculdade" e na sua "consciência técnica profissional", esperando que eles pudessem encontrar as respostas que aquele tempo colocava (PONTES, 1998, p. 68-69).

${ }^{174}$ O Museu de Arte Moderna de São Paulo foi criado por Francisco Matarazzo Sobrinho em 1948. Em 1949, o fundador convidou Lourival Gomes Machado, um dos integrantes do grupo Clima da Faculdade de Filosofia, para ser o diretor artístico da instituição. Nos dois anos em que lá esteve,
} 
a Clima e a Anhembi; editoras, como a Nacional e a Martins; cineclubes e a própria Cinemateca; grupos das artes plásticas e experimentais de teatro. ${ }^{175}$

A geração dos modernistas de 1922, depois de ter conquistado o seu espaço, se esgotou, tendendo ainda em muitos casos a posições politicamente reacionárias, conforme conta Antonio Candido à autora. Aos intelectuais que vieram na sequência coube a empreitada de prosseguir com a renovação cultual iniciada na década antecedente. No entender de Candido, os autores Sérgio Buarque de Holanda, Caio Prado Júnior e Gilberto Freyre, intérpretes que em nada deviam aos escritores estrangeiros, viabilizaram a "sedimentação da nossa literatura" e a "sistematização dos estudos de múltiplas facetas da realidade brasileira". ${ }^{176}$

Compreendendo esses aspectos do mundo intelectual, cultural e artístico da capital paulista, bem como as suas articulações com esses mundos no espaço brasileiro ao longo especialmente das décadas de 1940 e 1950, nota-se que o vínculo à Faculdade de Filosofia da USP era o que credenciava os críticos de arte, literatura, cinema que estavam se estabelecendo. Ao mesmo tempo rompendo e dando continuidade à ação disparada pelos modernistas dos anos 1920, o quadro dessas décadas em questão permite compreender as forças em relação no universo cultural, intelectual e artístico mobilizadas em torno das comemorações do quarto centenário da capital paulista, celebrado em 1954. ${ }^{177}$

No quadro dos empreendimentos que visavam à construção de uma capital cultural, na esteira da chamada tradição modernista que teve como um de seus principais centros irradiadores a cidade de São Paulo, Cortesão esteve em contato com alguns dos sujeitos e instituições imbuídos das iniciativas em questão. Tais relações podem ajudar a compreender as bases sobre as quais se assentou o intenso trabalho de organização da Exposição de História de São Paulo no quadro da história do

\footnotetext{
Machado realizou sessões cinematográficas no Museu e promoveu a I Bienal de São Paulo (outubro de 1951). Segundo Pontes, a pretensão de Machado era "cumprir bem duas tarefas principais: colocar a arte moderna do Brasil, não em simples confronto, mas em vivo contato com a arte do resto do mundo, ao mesmo tempo que para São Paulo se buscaria conquistar a posição de centro artístico mundial". Tempos depois, em 1962, Lourival Gomes Machado instalou-se em Paris, onde dirigiu o Departamento de Assuntos Culturais da UNESCO. Faleceu em Milão, em viagem de trabalho, em 1967 (PONTES, 1998, p. 196-200).

${ }^{175}$ PONTES, H. Op. cit., 1998, p. 36.

${ }^{176}$ CANDIDO, A. apud PONTES, H. Op. cit., 1998, p. 58.

177 Pontes, H. Op. cit., 1998, p. 63. Segundo Lofego, a consultoria técnica do Serviço de Comemorações Culturais da Comissão organizadora das comemorações tinha, entre outros, intelectuais como Sérgio Buarque de Holanda, Sérgio Milliet, Antonio Candido, Lourival Gomes Machado, Paulo Duarte, Herbert Baldus, Décio de Almeida Prado, Oswald de Andrade (2004, p. 62).
} 
Brasil, para o qual havia sido convidado por Francisco Matarazzo Sobrinho, principal responsável pelas comemorações dos quatrocentos anos de fundação da cidade.

À época em que Cortesão era secretário no Gabinete Português de Leitura, em 1943, o diretor da Biblioteca Municipal de São Paulo, Sérgio Milliet, escreveu ao escritor português pedindo o seu "apoio intelectual" para a organização de uma produção bibliográfica. Os artigos seriam remunerados e diriam respeito a temas como bibliografia, bibliofilia e outras atividades ligadas ao livro. ${ }^{178}$ Ainda que não tenha sido possível descobrir se a atividade foi ou não concretizada, destaco o intercâmbio entre os dois sujeitos e instituições bem como a importância que era reconhecida em Cortesão, muito provavelmente pelo fato de ter sido diretor ao longo de quase uma década da Biblioteca Nacional de Portugal e ter empreendido naquela instituição atividades como a que era proposta por Milliet para São Paulo. ${ }^{179}$

João Sarmento Pimentel, o seareiro que partiu de Portugal para São Paulo logo em 1927, se tornou um dos principais articuladores da comunidade portuguesa no Brasil. Presidente da Casa de Portugal entre 1940 e 1941, instituição fundada em 1935 para servir de apoio à comunidade portuguesa e luso-brasileira de diversas formas, o militar, falecido na capital paulista em 1987, gozava de excelente trânsito nos meios acadêmico e literário. ${ }^{180}$ Como se nota da intensa troca de correspondências entre Sarmento Pimentel e Cortesão - dos correspondentes catalogados no espólio Jaime Cortesão, o remetente com o maior número de missivas é ele, com 33 cartas, todas remetidas do estado de São Paulo, entre 1941 e 1960 - o amigo de longa data foi um dos grandes mediadores da atuação de Cortesão no meio paulista.

Além de tratarem de questões relativas a amigos portugueses, como Antonio Sérgio, sobre quem comentam das rusgas ocorridas entre este e Câmara Reys na direção da Seara Nova, as correspondências de Pimentel são profícuas em indicar as relações estabelecidas entre ele, Cortesão e diversos sujeitos do meio intelectual, cultural, político paulistano: na mesma correspondência, a primeira guardada de

\footnotetext{
${ }^{178}$ Milliet, S. Correspondência a Jaime Cortesão/Gabinete Português de Leitura. São Paulo, 20 set. 1943. BNP/ACPC E25/1047.

${ }^{179}$ Refiro-me às publicações do chamado "Grupo da Biblioteca", formado por Cortesão, diretor da Biblioteca Nacional de Portugal e seus amigos, que à mesma época se tornariam seareiros. Sobre o assunto, ver o capítulo 1 deste trabalho e SANTOS. Op. cit., 1993, p. 89.

180 Com informações disponíveis no sítio da Casa de Portugal: <http://www.casadeportugalsp.com.br/institucional/>. Acesso em 29 jun. 2015.
} 
Pimentel a Cortesão, de 1941, menciona palestra que tentaria arranjar junto a Simonsen. ${ }^{181}$

Em março de 1953, um mês depois de Cortesão retornar da viagem que tinha realizado a Portugal a serviço do Ministério das Relações Exteriores, à procura de documentos cartográficos para trabalhos encomendados pelo Itamaraty, Sarmento Pimentel aconselhou Cortesão a respeito do subentendido convite para tomar parte das comemorações ao quarto centenário paulistano, que teria lugar em menos de um ano. Entre o industrial ítalo-brasileiro Francisco Matarazzo Sobrinho, presidente da Comissão do IV Centenário da Cidade de São Paulo (CIVCCSP) e Jaime Cortesão, aparecem como intermediários Paulo Duarte e Sarmento Pimentel. Mencionando conversa com o jornalista paulista e ex-redator-chefe d'O Estado, Pimentel declara ter tocado nos assuntos que Cortesão tinha lhe solicitado: "jesuítas, governo português e seus delegados, recompensa, conselho consultivo, ida à Europa, auxiliares". Da conversa, o patrício de Cortesão diz ter tido "a melhor impressão", na certeza de que aceitando o convite, o historiador terá "as honras todas e todos os proventos de capitão da nau, facilidades, auxílio, cooperação, boa vontade dos componentes da autarquia do Centenário". ${ }^{182}$

De acordo com o que consta nas páginas d'O Estado de $S$. Paulo, dois dias antes da carta enviada por Pimentel, Cortesão tinha ido para Portugal não somente a serviço do Itamaraty. Também a CIVCCSP havia solicitado a ele a reunião de "todo o material possível para uma Exposição de Cartografia Antiga de São Paulo", que deveria compor "um dos pontos principais do grande programa com que se assinalará o 400 ${ }^{\circ}$ aniversário da fundação da metrópole paulista". O texto publicado no diário paulista reportava a reunião que Cortesão tinha tido um dia antes com Matarazzo, ocasião em que apresentara o relatório de sua viagem. A leitura do relatório do historiador português, bem como a entrega do material coletado, foi feita diante dos membros da comissão e de alguns historiadores convidados, entre os quais Aureliano Leite, Américo de Moura e Astrogildo Rodrigues de Mello.

O acervo levantado era composto por 150 fotocópias e decalques de "cartas, plantas e panoramas", acompanhado de catálogo com fichas descritivas. Dos trinta

${ }^{181}$ PIMENTEL, J. S. Correspondência a Jaime Cortesão. São Paulo, 14 jul. 1941. BNP/ACPC E25/756.

182 PIMENTEL, J. S. Correspondência a Jaime Cortesão. São Paulo, 22 mar. 1953. BNP/ACPC $\mathrm{E} 25 / 758$. 
arquivos visitados por Cortesão, 18 eram os depositários da documentação então apresentada, quase toda ela inédita. Segundo o texto, a exposição se chamaria "de Cartografia Antiga de São Paulo e do Mundo Paulista", acompanhada de catálogo e atlas histórico e seria dividida em seções,

compreendendo desde o descobrimento dos litorais a cartas de bandeirantes, o Tietê, limites, plantas e panoramas de cidade, vilas, portos fortalezas, saltos e monumentos históricos, aos mapas do astrônomo, explorador e cartógrafo paulista, Francisco de Lacerda e Almeida. A seleção será completada com uma coleção de peças existentes nos arquivos brasileiros. ${ }^{183}$

A correspondência de Sarmento Pimentel, a conversa com Paulo Duarte e a reunião entre Cortesão e Matarazzo permitem inferir que na ocasião em que apresentava a documentação coligida para uma exposição de cartografia, o historiador português tenha sido convidado a ampliar o escopo de sua contribuição às comemorações. Na correspondência, Pimentel ainda indica que Cortesão escreva uma carta "em caráter particular" a Paulo Duarte, expressando os seus termos para a o êxito de sua missão. Do ponto de vista do remetente, os questionamentos postos por Cortesão deveriam levar a uma resposta oficial "em termos que definam as suas atribuições e direitos", respondendo às exigências de ordem "política, moral e profissional, ordenados, auxiliares e outros detalhes que lhe convenham".

Ainda na correspondência, Sarmento Pimentel, gerenciando a interação, reitera seu incentivo falando do entusiasmo que a apresentação de Cortesão havia despertado naquelas pessoas, incutindo nelas a certeza de que somente o historiador seria capaz de realizar uma obra "a ser admirada pelo mundo culto que estará presente nas festas do Centenário da cidade". Tal certeza, do ponto de vista de Pimentel, levaria "a autarquia [CIVCCSP] a entregar-lhe, sem restrições, essa missão (...)", que ninguém deixaria de chamar de "gloriosa para Portugal, honrando os bandeirantes, o Brasil, prestigiando a ciência e alta cultura latinas". Concluindo a correspondência, o remetente ressalta a sua confiança no trabalho de Cortesão, acreditando que o amigo colocará "nos seus lugares o saber e a arte dos portugueses, espanhóis, italianos" nas efemérides de 1954. Pimentel recorre à importância política e patriótica que teria o papel proeminente do historiador nas comemorações do aniversário de São Paulo: a ocasião era "única, magnífica" e abria "uma estrada

\footnotetext{
${ }^{183}$ O IV Centenário da Cidade. Exposição de cartografia antiga de S. Paulo. Coroada de êxito a missão do Prof. Jaime Cortesão em Portugal - apresentado ontem à Comissão do IV Centenário o valioso material iconográfico que figurará no certame. In: O Estado de S. Paulo, 20 mar. 1953, p. 10.
} 
larga" para um destino recompensador e justo para com o caráter de Cortesão, que com "esforço, talento, coragem" teria se imposto "a gregos e troianos". ${ }^{184}$

Além de indicar os caminhos para que Cortesão se fizesse ouvir em suas condições perante os organizadores do conjunto dos festejos, Sarmento Pimentel é taxativo em lembrar da importância cívica/patriótica que Cortesão desempenharia aceitando a tarefa que lhe solicitavam. Chamam a atenção, inclusive, os termos finais da missiva, em que o remetente se refere ao fato do historiador ter se imposto "a gregos e troianos", em uma possível alusão aos pontos de vista divergentes entre os quais Cortesão tinha transitado ao longo de sua atuação no mundo intelectual e político brasileiro.

Paulo Duarte já tinha, dois anos antes, se dirigido diretamente a Cortesão. Em fins de 1950, o jornalista d'O Estado comunicava o lançamento de "uma revista de alta cultura diferente" das que até então tinham aparecido no país, "orientada por um espírito universal", motivo pelo qual havia convidado e recebia apoio "dos melhores nomes" de diversos países - Portugal, Espanha, França, Itália, Estados Unidos. Explicitando o sentido da nova revista, Duarte dizia desejar publicar em cada edição, ao lado dos textos dos estrangeiros, "outras tantas ou mais de brasileiros realmente representativos de nossa vida intelectual, evitando tantos simuladores de cultura que procuram impor-se por aí". O jornalista, que também havia estado nas fileiras de 1932 e que era próximo de Júlio de Mesquita Filho, ressaltou que, à vista do seu programa, "não podia evidentemente dispensar" a colaboração de Cortesão, convite que faz então sem "nenhuma condição a impor, podendo tratar de assunto que bem entender, dimensões que julgar conveniente". Duarte indica o preço que pagaria pela colaboração e pede para que Cortesão contribua escrevendo ao menos três ou quatro artigos anuais. A revista em questão seria Anhembi,

que é o nome dado pelos índios no século XVI ao Tietê, que passou a ser um símbolo de penetração geográfica, num tempo em que no Brasil não havia regionalismos. Anhembi de hoje sonha tornar-se também um símbolo de penetração cultural sem regionalismos. ${ }^{185}$

Das palavras de Paulo Duarte, notam-se posicionamentos evidentes diante dos panoramas intelectual e cultural do país, condenando especialmente o que

\footnotetext{
${ }^{184}$ PIMENTEL, J. S. Op. cit., 22 mar. 1953. BNP/ACPC E25/758. Pimentel encerra a carta chamandose "moço de recados" e "auxiliar".

${ }^{185}$ DuARTE, P. Correspondência a Jaime Cortesão. São Paulo, 14 nov. 1950. BNP/ACPC E25/436. Sobre o autor, cf. MeNDES, E. G. Paulo Duarte In: Estudos Avançados, São Paulo, v. 8, n. 22, 1994.
} 
chama de regionalismos. Mais uma vez, como em diversas iniciativas, ideias e programas daquele contexto, a identificada fragmentação regional brasileira é considerada um dos problemas a superar. Ao que o editor da revista que circulou entre 1950 e 1962 disse na carta-convite enviada a Cortesão, a inspiração da penetração geográfica do passado, que teria dado ao Brasil a sua fisionomia, era o ideal a ser perseguido em tempos de divisão. Como não poderia deixar de ser, em se olhando para o passado bandeirante, o papel dessa integração partiria de uma iniciativa paulista.

No mesmo ano de 1950 é possível verificar vínculos de Cortesão com dois espaços de produção do conhecimento histórico paulista: o Instituto Histórico e Geográfico de São Paulo e a Faculdade de Filosofia, Ciências e Letras da Universidade de São Paulo. Em fevereiro, Cortesão recebeu uma correspondência comunicando a sua eleição como sócio-correspondente do IHGSP. ${ }^{186} \mathrm{Em}$ julho do mesmo ano, no exercício do cargo de diretor da FFCL, Eurípedes Simões de Paula, convidou Cortesão para realizar duas conferências em comemoração ao bicentenário da assinatura do Tratado de Madri, sob o patrocínio do Departamento de Cultura da USP. ${ }^{187}$ Do interior da Universidade, Cortesão se correspondeu também com as professoras Alice Piffer Canabrava e Myriam Ellis, filha de Alfredo Ellis Júnior.

A correspondência de Alice Canabrava, alguns meses anterior a de Eurípedes Simões de Paula, comenta sobre a possibilidade de "enfim" ouvir Cortesão falar na Faculdade de Filosofia. Ainda na expectativa de que a direção da FFCL e a reitoria da USP encampem a ideia - como a correspondência de Simões de Paula acima mencionada atestou - a historiadora informa ao seu interlocutor que o texto da conferência sobre Alexandre de Gusmão já estava com o diretor e pronta para ser publicada no quarto volume da Revista de História. Na ocasião, a autora enviava textos seus para que Cortesão the enviasse as suas críticas. ${ }^{188}$ As duas correspondências de Myriam Ellis, de anos posteriores, dizem respeito às pesquisas empreendidas pela historiadora, agradecendo o interesse de Cortesão por seu tema de pesquisa e trocando informações sobre documentos e arquivos. Na ocasião, Ellis

\footnotetext{
${ }^{186}$ SILVEIRA, C. Correspondência a Jaime Cortesão. São Paulo, 6 fev. 1950. BNP/ACPC E25/1048. Cortesão também teve a sua solicitação aprovada como sócio-correspondente do IHGB, em 1952. Cf. CORREA FILHO, V. Correspondência a Jaime Cortesão. Rio de Janeiro, 27 out. 1952. BNP/ACPC E25/330.

${ }^{187}$ PAULA, E. S. Correspondência a Jaime Cortesão. São Paulo, 22 jul. 1950. BNP/ACPC E25/725. ${ }^{188}$ CANABRAVA, A. P. Correspondência a Jaime Cortesão. São Paulo, 23 abr. 1950. BNP/ACPC E25/1109.
} 
transmite a Cortesão os agradecimentos de seu pai, Alfredo Ellis Jr., "sensibilizado" com a consideração do historiador português. ${ }^{189}$ Além dessas relações, o arquivo do historiador português permite identificar como interlocutores no interior da Faculdade de Filosofia dois professores portugueses, Joaquim Barradas de Carvalho e Fidelino de Figueiredo.

Quando Cortesão partiu para a Europa incumbido de levantar documentos, objetos e outros elementos para a organização da Exposição de História de São Paulo, chegou, por meio do Ministério dos Negócios Estrangeiros de Portugal e da Comissão Provisória Portuguesa do Centenário de São Paulo, a informação ainda incerta da realização de um Congresso Internacional de História na cidade de São Paulo. Ainda que já presumindo a sua não realização, o organismo transcreveu o programa do evento para que, se fosse do interesse de Cortesão, ele preparasse a sua comunicação. A comissão provisória encarregada de organizar a participação portuguesa nos festejos se pôs à disposição do historiador, garantindo informa-lo de tudo quanto dissesse respeito ao assunto e desejando que participasse e prestasse "a sua valiosa colaboração para o brilho da representação portuguesa". ${ }^{190}$

O congresso estava previsto para realizar-se entre 15 e 21 de setembro de 1954, na sede da Faculdade de Filosofia, Ciências e Letras da Universidade de São Paulo, local que poderia vir a ser alterado caso conviesse. O patrocínio do evento ficaria por conta da Faculdade e da Sociedade de Estudos Históricos. Indica-se ainda no documento a possibilidade de outras instituições patrocinarem, mencionando a Universidade Católica de São Paulo, a Universidade Mackenzie, a Faculdade de Ciências Econômicas da USP, a Escola Livre de Sociologia e Política, o IHGSP, o Museu Paulista, o Departamento de Cultura da USP, o Departamento de Cultura da cidade de São Paulo, o IHGB, o Departamento de Arquivo do Estado. ${ }^{191}$ Essa lista de instituições, em sua maioria com sede na capital paulista, descreve quais organismos poderiam tomar parte de um evento relacionado à história local. Indica, dessa forma,

\footnotetext{
${ }^{189}$ ELLIS, M. Correspondência a Jaime Cortesão. São Paulo, 24 out. 1953/7 mai. 1955. BNP/ACPC E25/439-440.

${ }^{190}$ Portugal. Ministério dos Negócios Estrangeiros. Comissão Provisória Portuguesa do Centenário de São Paulo. Congresso Internacional de História. Transcrição datilografada do regulamento original, elaborado pelos professores da Faculdade de Filosofia, Ciências e Letras da Universidade de São Paulo. Circular n. 8, Lisboa, 11 dez. 1953, p. 1. BNP/ACPC E25/Caixa 64, Pasta 20.

${ }^{191}$ PAULA, E. S. et al. Congresso Internacional de História. Transcrição datilografada, feita pelo Ministério dos Negócios Estrangeiros de Portugal, do regulamento original. Circular n. 8, Lisboa, 11 dez. 1953, p. 2-3. BNP/ACPC E25/Caixa 64, Pasta 20.
} 
os lugares de produção do conhecimento histórico então reconhecidos pelos pares. Do exterior, os professores da Faculdade de Filosofia pretendiam contar com o apoio da Société Intenationale d'Histoire (Paris) e do Instituto Pan-Americano de Geografia y Historia (México). O evento aconteceria em conexão com a reunião do Comité d'Histoire de l'Humanité, da UNESCO, previsto para acontecer na capital paulista naquela ocasião.

O regulamento em seguida delineia as seções nas quais se dividiria o evento: "o Congresso será dividido em dez seções, conforme o temário estabelecido e com funcionamento independente". Toda seção teria um presidente, um adjunto e um secretário, "este último brasileiro ou português". Cada seção, obrigatoriamente, apresentaria ao menos uma memória inédita, de 50 a cem páginas e ao término de cada uma, conclusões breves seriam apreciadas em sessões plenárias. ${ }^{192} \mathrm{O}$ temário, dividido em três grupos, é o seguinte:

1. ${ }^{\circ}$ grupo: Fatos da história mundial aos quais está ligada a história do Brasil:

1. História dos jesuítas e de suas fundações na América;

2. História da penetração nos continentes, particularmente do bandeirismo no Brasil;

3. História das plantas tropicais e a contribuição do Brasil.

2. ${ }^{\circ}$ grupo: Aspectos fundamentais da estrutura do mundo moderno.

4. História sociológica dos povos da América;

5. História moderna das cidades;

6. História moderna do comércio marítimo;

7. História das instituições monetárias capitalistas e das crises;

8. As grandes correntes do pensamento americano e suas relações com o pensamento europeu.

3. ${ }^{\circ}$ grupo: Métodos.

9. História comparada dos países do hemisfério austral;

10. A Cartografia em História. ${ }^{193}$

Os professores da Faculdade de Filosofia que subscreveram o documento original, na documentação do espólio de Cortesão transcrito e assinado pelo Ministro Plenipotenciário Miguel Pile, foram Eurípedes Simões de Paula, presidente da Comissão Executiva do Congresso; Eduardo d'Oliveira França, secretário; Charles Morazé, secretário estrangeiro e Thomaz Oscar Marcondes de Souza, tesoureiro. Segundo Lofego (2004), que realizou um trabalho fundamental sobre o conjunto das

\footnotetext{
192 PAUlA, E. S. et al. Op. cit., 1953, p. 6-7. BNP/ACPC E25/Caixa 64, Pasta 20.

${ }^{193}$ PAUlA, E. S. et al. Op. cit., 1953, p. 8-10. BNP/ACPC E25/Caixa 64, Pasta 20.
} 
comemorações em torno do quarto centenário da cidade de São Paulo, o memorial apresentado pelos professores estava em consonância com as inovações que os professores estrangeiros - franceses - imprimiam na operação historiográfica realizada no Brasil, a partir do seio da Faculdade de Filosofia da USP. Se por um lado essa escrita "valorizou o cotidiano", segundo Lofego, "por outro procurava sempre concebê-la inserida dentro de um contexto cujo centro era a Europa". Citando correspondência de Eurípedes Simões de Paula para Francisco Matarazzo Sobrinho, que apresenta redação semelhante à que foi transcrita pelo Ministério dos Negócios Estrangeiros de Portugal a Cortesão, Lofego comenta que, a partir de um esforço acadêmico, "o congresso buscaria diminuir a distância entre a história do Brasil, em particular a de São Paulo, e a história do continente europeu, com finalidade de ampliar as pesquisas de história do Brasil". Ainda de acordo com Lofego, "a amplitude dos temas propostos destoava um pouco da ênfase que a Comissão buscava dar à metrópole de São Paulo". ${ }^{194}$

Considerando a reflexão ao longo do trabalho de Silvio Lofego, lançado no ano em que São Paulo comemorava também grandiosamente os seus 450 anos, em 2004, o Congresso Internacional de História, mais interessado em fomentar a pesquisa e a produção histórica, não encontrava eco nos objetivos pensados pela CIVCSSP, de descrever um passado heroico que justificasse o vigor do presente $\mathrm{e}$ as potencialidades futuras da metrópole. No fim das contas, sob a alegação maior da falta de recursos, e devido aos desencontros entre a autarquia municipal à testa das comemorações e o grupo de professores da Faculdade de Filosofia, o congresso não se realizou. O evento de história de maior destaque, também na esteira da relação entre São Paulo, Brasil e Europa, foi a Exposição de História de São Paulo no quadro da História do Brasil, com curadoria de Jaime Cortesão. ${ }^{195}$

As comemorações da passagem do $400 .^{\circ}$ aniversário da fundação da cidade de São Paulo, girando em torno da data simbólica de 25 de janeiro de 1954, foram interpretadas pelo historiador Silvio Luiz Lofego como sendo uma importante articulação entre o passado e o futuro da metrópole. A projeção de futuro tinha como ponto de partida o passado, que na ocasião deveria ser narrado "à altura das aspirações do presente". A narrativa histórica em questão estava articulada a um

\footnotetext{
${ }^{194}$ LOFEGo, S. L. IV Centenário da Cidade de São Paulo: uma cidade entre o passado e o futuro. São Paulo: Annablume, 2004, p. 178-180.

${ }^{195}$ LOFEGO, S. L. Op. cit., 2004, p. 180.
} 
conjunto complexo de encontros, desfiles, congressos, eventos esportivos, artísticos, cívicos, gestados ao longo do ano anterior. Para além dos objetivos locais, o autor destaca "o papel da festa comemorativa para o sucesso da propaganda paulista, que divulgou São Paulo como modelo para o Brasil", fazendo frente à então capital do país, o Rio de Janeiro, centro de todas as atenções. Enquanto propaganda comemorativa, Lofego constrói sua análise pensando em como se incutiu na população, local ou de outros cantos do país e mesmo de fora dele, a importância de celebrar aquela efeméride. ${ }^{196}$

A base do trabalho das comemorações estava assentada um uma autarquia denominada Comissão do IV Centenário da Cidade de São Paulo (CIVCCSP), formada "por membros representativos da força econômica de São Paulo, além daqueles nomes ligados à classe intelectual, como jornalistas, escritores e professores universitários". Em dezembro de 1951, um decreto definia que a Comissão "era uma entidade autárquica, com personalidade jurídica e patrimônio próprio, diretamente controlada pela Prefeitura do Município de São Paulo". Foi nomeado como presidente Francisco Matarazzo Sobrinho (1898-1977), que além de diretor das Indústrias Reunidas Francisco Matarazzo, maior parque industrial latino-americano, fundou o Teatro Brasileiro de Comédia e a Companhia Cinematográfica Vera Cruz. Criador da Bienal de Artes e comprador de diversas obras de arte para os museus locais, era considerado o mecenas da cidade. ${ }^{197}$

Como pondera Lofego, das atividades empreendidas a partir da autarquia, dois núcleos foram fundamentais para o sucesso das comemorações, no que diz respeito especialmente à celebração da história da cidade:

[o] primeiro seria a construção da história de São Paulo, tanto nas reedições quanto em novas produções que atendessem às expectativas da Comissão. $\mathrm{O}$ segundo seria a propaganda ancorada nessa produção histórica, que por sua vez legitimaria todo o empenho dispensado para a realização dos festejos. ${ }^{198}$

A intensa propaganda, como reitera o autor ao longo de seu trabalho, seria a alma do sucesso das comemorações. Diante da heterogeneidade da cidade, o "bombardeio ufanista", como Lofego diz, não abria maiores espaços para as vozes divergentes dos grupos sociais alijados das comemorações, como as comunidades negras e pobres da cidade, bem como artistas, intelectuais e outros sujeitos que não

\footnotetext{
${ }^{196}$ LOFEGO, S. L. Op. cit., 2004, p. 29; 32.

${ }^{197}$ LOFEGO, S. L. Op. cit., 2004, p. 37; 41-43.

${ }^{198}$ LOFEGO, S. L. Op. cit., 2004, p. 44-45.
} 
figuraram entre os escolhidos. A partir dessa prática, a Comissão homogeneizava a sociedade e a sua história, constituindo uma narrativa que supostamente abarcaria a todos, que seriam inclinados a aderir ao discurso hegemônico produzido e largamente difundido sobre São Paulo, seu passado, seus símbolos e seus projetos de futuro. ${ }^{199}$

Em suma, na elaboração do calendário festivo, fez-se questão de ressaltar por meio da grandiosidade o aspecto econômico, que se referia diretamente à prosperidade paulista. A bandeira da riqueza não seria apenas para que o mundo além dos muros paulistanos visse. Tratava-se, na concepção de Lofego, a constituição de uma autoimagem que refletisse a construção hegemônica da cidade de São Paulo. Diante da necessidade "de um campo simbólico para fomentar a memória que se pretendia forjar", o quarto centenário se apresentava "como um espaço privilegiado desse processo". ${ }^{200}$

Naquele contexto, as transformações do espaço da cidade de São Paulo também agiram sobre as percepções da população em relação à vida urbana. Tomando como referência a produção fotográfica de German Lorca (1922-), fotógrafo formado nas experimentações do Foto Cine Clube Bandeirante (década de 1940), grupo que teria revolucionado o modo de fotografar a cidade ${ }^{201}$, é possível inferir sobre como as modificações do espaço urbano teriam produzido novos sentidos para a apreensão da cidade. Do ponto de vista de Martins, as imagens produzidas por Lorca, que sobe no topo de edifícios ou na torre da Catedral da Sé ainda em construção, são como uma resistência às linhas que, se verticalizando,

\footnotetext{
${ }^{199}$ Ainda assim, artistas como Villa-Lobos manifestaram a sua indignação frente à indiferença com a qual a Comissão tratava artistas nacionais em detrimento de estrangeiros. No interior do próprio grupo, Lofego traz à discussão a tentativa do diretor de relações públicas em encaminhar ao segundo presidente da CIVCCSP, o poeta Guilherme de Almeida, a proposta de homenagem ao músico Mário Zan, que compôs uma música em comemoração ao aniversário da cidade. A proposta, que reconheceria que elementos externos à Comissão tinham conseguido mais êxito na mobilização popular, foi rejeitada pelo secretário Boanerges do Amaral Gurgel e por Guilherme de Almeida. Outro caso emblemático diz respeito ao projeto do Monumento à Mãe Preta, a ser erigido no Largo do Paissandu, enviado ao Serviço de Comemorações Culturais pela Comissão de Festejos. Rejeitada em diversas ocasiões, a proposta somente foi aceita quando uma frente em defesa do monumento decidiu apresentar um abaixo-assinado à CIVCCSP. O grande apelo fez com que a inauguração do monumento integrasse as comemorações oficiais. Iniciativas como o Museu de Cera a ser instalado no Ibirapuera, proposto pelo Grupo de Industriais e Artistas, foi aceito sem resistência (LOFEGO, 2004, p. 48-51).

${ }^{200}$ LOFEGO, S. L. Op. cit., 2004, p. 38.

${ }^{201}$ MARTINS, J. S. A poesia da fotografia paulistana de Lorca. In: LORCA, G. A São Paulo de German Lorca. Texto de José de Souza Martins. São Paulo: Imprensa Oficial do Estado de São Paulo/Secretaria Municipal de Cultura, 2013, p. 7.
} 
roubam o horizonte da cidade. ${ }^{202}$ Fez-se necessário, naquele momento em que a modernidade e os seus signos transformavam as perspectivas, buscar outros pontos de observação para que a vista alcançasse a linha do horizonte. O fotógrafo, que fez registros da construção da Catedral da Sé e do Parque Ibirapuera, foi o fotógrafo oficial da Editora Abril para as comemorações do quarto centenário da cidade de São Paulo. ${ }^{203}$

As fotografias selecionadas por Lorca (2013) e que compõem A São Paulo de German Lorca permitem não somente identificar alguns dos elementos marcantes da identidade visual da cidade, como o edifício Altino Arantes, inaugurado em 1947 e durante alguns anos o edifício mais alto do país, como uma profusão de canteiros de obras, como as do Parque Ibirapuera e da Catedral da Sé, ambas construções do contexto das comemorações centenárias de 1954. Em uma das tomadas, a grande avenida construída no Vale do Anhangabaú compõe um quadro com a sede do então Banco do Estado de São Paulo, o edifício Altino Arantes, inspirado no Empire State Building, um dos principais emblemas nova-iorquinos. ${ }^{204}$ São Paulo, construindo novamente as suas representações, como havia feito nos tempos da Belle Époque, era um paradigma de cidade em exposição ${ }^{205}$ : os signos e sentidos da modernidade que já tinham sido à europeia agora aspirava o ideal dos Estados Unidos.

Entre aspirações de futuro e modificações profundas do espaço urbano, cenário e suporte das relações sociais e das operações que se realizaram para produzir imagens e sentidos para a história e a memória paulistanas, não haverá, no contexto das comemorações do quarto centenário, lugar mais significativo do que o Parque Ibirapuera. Para compreender os sentidos encerrados na construção do parque e dos monumentos em sua órbita, sigo a intepretação que faz Paulo César Garcez Marins (1999), partindo da análise instigante de três dos principais "empreendimentos artísticos de caráter monumental" construídos até a data do quarto centenário de São

\footnotetext{
${ }^{202}$ MARTins, J. S. Op. cit., 2013, p. 9.

${ }^{203}$ MARTins, J. S. Op. cit., 2013, p. 11-12.

${ }^{204}$ LORCA, G. Viaduto Santa Ifigênia, 1953. Reprodução fotográfica, p/b., São Paulo. In: $O p$ cit., 2013, p. 17.

${ }^{205}$ Aproprio-me aqui da ideia que Heloisa Barbuy (2006) utiliza para compreender a dinâmica da transformação da cidade de São Paulo da Belle Époque, em que a profusão de vitrines introduzia a linguagem das exposições para a vida comercial urbana. Compreendo, a partir das reflexões que a leitura das imagens de Lorca e a interpretação do contexto permitem, que as modificações de grande porte então levadas a cabo, levantado arranha-céus e abrindo vias ao automóvel, expunham um paradigma de cidade moderna, desenhado a partir dos anseios das elites locais e nacionais na metade do século passado e destinado a se irradiar pelo país.
} 
Paulo: o Monumento às Bandeiras, o Monumento e Mausoléu ao Soldado Constitucionalista de 1932 e os pavilhões para as exposições comemorativas do $400 .^{\circ}$ aniversário da cidade. De acordo com Marins,

[c]oncentraram-se ali os símbolos de caráter comunitário, propostos ou subsidiados pelo poder público, todos eles diretamente ligados à representação da identidade paulista, do ser paulista, atos afirmativos necessariamente impactantes em anos de grandes transformações demográficas, sociais e culturais não só para a cidade, como para seu estado e para o próprio país.

Ainda segundo o autor, as obras, concebidas em décadas distintas e erigidas entre 1953 e 1955, permitem a percepção de "mutações arquiteturais e escultóricas" que expressam uma múltipla consciência, assim como o "caráter ideológico de círculos culturais articulados ao poder público no esforço por dotar a capital de símbolos que evidenciassem, ou unissem os muitos e múltiplos paulistas". Guiandose pelo mito bandeirante, "a mais eficiente e duradoura construção simbólica operada no estado durante a primeira metade do século XX", Marins constrói uma interpretação sobre a plástica adotada nas três realizações destacadas, analisando os meandros da "afirmação, transformação e diluição dos nexos entre o ser paulista, seu passado e a formulação de seu futuro". ${ }^{206}$

A construção do mito bandeirante, intimamente relacionada à ascensão das elites paulistas no cenário político e econômico nacional desde fins do XIX, se prestava a revestir de legitimidade histórica as ações desses mesmos sujeitos, representados por aqueles ligados aos negócios do café e ao próprio governo republicano da República Velha. De alguma forma, a história desses agentes históricos acaba por ser vinculada também aos primórdios da colonização e à proclamação da independência ${ }^{207}$, eventos da história nacional que têm no planalto paulista o seu cenário. As operações que se davam em torno da invenção histórica ${ }^{208}$

\footnotetext{
${ }^{206}$ MARINS, P. C. G. O Parque do Ibirapuera e a construção da identidade paulista. In: Anais do Museu Paulista, São Paulo, nova série, v. 6/7, n. 1, 1998/1999, p. 9-10. Grifos do autor.

${ }^{207}$ Segundo Marins, a esses dois eventos se dedicavam dois dos principais monumentos históricos até então erigidos no espaço da cidade de São Paulo: o Glória imortal aos fundadores de São Paulo, projetado em 1913 e inaugurado em 1925, no sítio histórico da fundação, o Pátio do Colégio, então Largo do Palácio; e o Monumento à Independência, inaugurado às margens do riacho do Ipiranga no ano de 1922, centenário da proclamação da independência brasileira (MARINS, 1999, p. 11).

${ }^{208}$ Utilizo aqui a ideia a que Antonio Celso Ferreira (2002) recorre no seu magistral exercício de análise do processo de criação de uma narrativa histórica, de heróis, de símbolos, de elementos da identidade paulista. Abordando o período que se estende de 1870 a 1940, o autor examina o papel do IHGSP, da Academia Paulista de Letras, dos romances e almanaques literários e do movimento modernista, entre outros aspectos da vida cultural regional.
} 
paulista/bandeirante criavam um "complexo jogo de interpretações distorcidas e mutáveis, num jogo elástico que estenderia seu vigor até a década de inauguração dos monumentos do Ibirapuera", nos anos $1950 .^{209}$

Mesmo que nos primeiros tempos da construção mitológica somente o grupo dos que se enfurnavam nos arquivos ostentasse o "orgulho de ser paulista", as suas iniciativas abriram os caminhos para que a narrativa do passado de homens rústicos e empobrecidos ganhasse contornos de epopeia de "heroicos e intrépidos bandeirantes", figuras das quais a princípio se ufanariam apenas as elites do café. Lançadas as bases para o que Marins chama de "reconciliação ideológica entre as elites e o passado paulista", a construção simbólica do mito, elástica, permitiria não apenas a coesão entre as camadas dirigentes, como também as diferenciaria dos demais paulistas, por sua vez distinguidos dos demais brasileiros. No sentido do processo em torno dessas construções,

[o] IV centenário de São Paulo seria o ponto culminante da materialização na paisagem urbana das alegorias bandeirantes e, simultaneamente, o momento em que se entrevia o esgotamento do passado como formulador de um futuro já incontornavelmente liderado por novos agentes sociais e expressões culturais cosmopolitas, cujos liames com os velhos símbolos paulistas se esgarçariam rapidamente no decorrer da segunda metade do século XX. ${ }^{210}$

Isto quer dizer que, à época das comemorações de 1954, novas operações seriam necessárias para que o mito construído continuasse a ser elemento de identidade regional. Com novos agentes e novos referenciais, o bandeirante precisava se renovar para continuar a efetuar o seu papel de coesão social. As mobilizações em torno do mito, então, vão além das condições que já abordamos até agora. Para Paulo César Garcez Marins, cada um dos três elementos escolhidos do conjunto do Ibirapuera diz respeito a uma leitura possível do mito, de acordo com temporalidades e sujeitos distintos. Sigamos a sua perspectiva.

O Monumento às Bandeiras, de acordo com Marins, possui nítido vínculo com o contexto em que o mito bandeirante se consolidava. Ainda sem local definido, o primeiro projeto do monumento havia sido desenhado por Victor Brecheret em 1920, planejado para o centenário da independência. Por trás da inciativa estavam sujeitos que anos depois estariam em ênfase, como Menotti del Picchia, Oswald de Andrade e Monteiro Lobato. A maquete e os estudos posteriores "uniam a despersonalização

\footnotetext{
${ }^{209}$ MARINS, P. C. G. Op. cit., 1999, p. 11-12.

${ }^{210}$ MARINS, P. C. G. Op. cit., 1999, p. 13.
} 
dos homenageados", fazendo-os todos igualmente bandeirantes. A massa escultórica representaria a massa humana e a sua força, avançando pelas terras desconhecidas dos sertões, visando à integração da pátria. ${ }^{211}$

Soluções formais foram modificando o projeto original, adotadas de modo a identificar as três raças do período colonial, esculpido a partir de outros referenciais que não os de projetos anteriores, ainda que permanecendo todos despersonalizados. Facilitava-se assim a identificação mais ampla de diversos paulistas (e brasileiros). Em 1942, Brecheret não fala em bandeirantes e sim em "espírito das bandeiras", num "ímpeto nacional que arrastou essas formidáveis massas humanas para os sertões", espírito este de acordo com o espírito do Estado Novo, acima de regionalismos em nome de uma unidade. Às vésperas da inauguração do monumento em 1953, o escultor prosseguia com o esforço de "desvincular o monumento de conteúdos regionais para um alcance muito mais abrangente e ambicioso", falando mesmo em "Altar da Pátria", onde estariam as três raças formadoras do país - índio, negro e branco - o que não significa, segundo Marins, necessariamente "o português ou o mameluco bandeirante". Permanecendo o símbolo bandeirante, em parte descolado de sua carga excludente, agregavam-se os "forasteiros", imigrantes europeus. ${ }^{212}$ Tais eram, segundo Marins, os bandeirantes do passado.

Os bandeirantes do presente estariam encerrados na simbologia do Monumento Mausoléu ao Soldado Constitucionalista de 1932, que teve a sua construção iniciada em 1951, anos após o concurso realizado em 1934. Em ritmo acelerado, deveria estar pronto a tempo dos festejos centenários da cidade, quando enfim foram depositados os primeiros restos mortais no mausoléu. Sua inauguração, parcial, foi no ano de 1955. Bastante explorada ao longo do levante de 1932, a figura do bandeirante se tornou um dos principais elementos de mobilização da população, congregando os paulistas e os combatentes pela promulgação de uma nova constituição, motivo declarado do levante contra Vargas e o governo instituído em 1930. Naquele momento, o fortalecimento da identidade interna distanciava o paulista do brasileiro. $^{213}$

A aproximação entre sertanistas e combatentes, de acordo com a leitura de Marins, "testemunha a herança paulista", insinuada pela solução formal da repetição

\footnotetext{
${ }^{211}$ Marins, P. C. G. Op. cit., 1999, p. 14.

${ }^{212}$ MARINS, P. C. G. Op. cit., 1999, p. 18.

${ }^{213}$ MARINS, P. C. G. Op. cit., 1999, p. 20.
} 
humana em sobreposição, que dá sentido de coletividade. A provável inspiração do escultor Galileo Emendabili vem dos painéis italianos da Mostra della Rivoluzione Fascista de 1933. Além disso, as expressões corporais e faciais das esculturas de Emendabili também se assemelham às soluções estéticas da escultura italiana durante a vigência do fascismo. Para Marins, "a marca corpórea e moral do passado migra sucessivamente do bandeirante para o soldado", e por fim, nos mosaicos do interior do monumento, se apresenta também no agricultor e no trabalhador urbano. Amalgamam-se temporalidades e refundam-se os sentidos da identidade local. ${ }^{214} \mathrm{O}$ atraso da obra, inaugurada apenas em 1955, permitiu a Emendabili ousar na italianidade do monumento, que pôde assim assegurar, nesse novo momento da representação identitária paulista, a inclusão do imigrante na identidade bandeirante. As antigas famílias, orgulhosas de seus ancestrais sertanistas, por meio de seus matrimônios e descendentes, também unia "bandeirantes" a imigrantes. ${ }^{215}$

Por fim, a análise de Marins sobre os símbolos da identidade paulista, calcada no mito bandeirante, e articuladas no espaço do Parque Ibirapuera se debruça sobre o conjunto arquitetônico projetado para abrigar as exposições em comemoração ao 400. ${ }^{\circ}$ aniversário da fundação da cidade de São Paulo, em 1954. Mais por força das circunstâncias do que por intencionalidade, todas as intervenções na região foram inauguradas no curto período de três anos, em torno da data da comemoração centenária. A cidade agrícola se tornava o símbolo da industrialização e com isso, superava as referências à terra e à agricultura para "definir-se de maneira essencialmente urbana, cosmopolita - e de abrangência nacional". Nos três principais pavilhões da $1^{a}$ Feira Internacional de São Paulo, no Ibirapuera, destacava-se a produção industrial local, a mostra das nações (26 no total) e dos estados brasileiros. Outros eventos se davam no mesmo espaço do parque - e como vimos, na cidade - com grande destaque para as artes e para a história, como na exposição organizada por Cortesão. ${ }^{216}$

Os projetos de Oscar Niemeyer (1907-2012) são ligados à escola carioca de arquitetura bem como ao pensamento de Lúcio Costa (1902-1998) e inspiram-se sobretudo no passado colonial do país e na geografia fluminense. Abusando de curvas, claros e escuros, revestimentos tradicionais como azulejos, volumes limpos,

\footnotetext{
${ }^{214}$ MARINS, P. C. G. Op. cit., 1999, p. 22.

${ }^{215}$ MARINS, P. C. G. Op. cit., 1999, p. 26.

${ }^{216}$ MARINS, P. C. G. Op. cit., 1999, p. 26.
} 
escalas precisas e outros elementos de Le Corbusier (1887-1965), as propostas plásticas de Niemeyer, Costa e outros arquitetos modernistas buscavam "uma identidade estética e formal de caráter nacional, algo comum a muitos grupos modernistas". Marins comenta que a projeção dos edifícios do Ibirapuera estava livre de alegorias e referências ao passado, seja ele local ou nacional. Ao contrário do que tinha feito no conjunto da Pampulha, em Belo Horizonte, as obras de Niemeyer no parque paulistano não usaram recursos como azulejos ou pedras de Itacolomi, abrindo assim mão de referenciais cromáticos e materiais ao passado colonial. Sem espaço para o passado, o progresso despontava, representado oficialmente em uma estética "livre de preconceitos, de associações regionais, de apelos passadistas excludentes", como nos outros dois monumentos apresentados. Tal operação, de acordo com Marins, tornava viável "a extensão da identidade paulistana e paulista a todo o país, liderando e modelando os brasileiros na era da industrialização e da tecnologia". 217

Getúlio Vargas, no exercício do mandato presidencial para o qual tinha sido eleito em 1950, foi recebido em um banquete oficial, oferecido pelo Governador de São Paulo, Lucas Nogueira Garcez, na véspera do grande dia 25 de janeiro de 1954. Na ocasião, o Presidente da República discursa:

Esta é a metrópole poderosa, [po]pulação ordeira, disciplinada e laboriosa, os que [sic] vêm de todos os rincões do Brasil e do mundo, em busca de um viver melhor. São Paulo não conhece preconceitos de qualquer ordem. Abre a perspectiva generosa de suas oportunidades que absorve e integra, num só povo a todos e a cada um, porque sabe que o progresso de cada um será o progresso de todos. ${ }^{218}$

As palavras de Vargas faziam eco, portanto, das vozes locais, referindo-se inclusive às migrações e imigrações que tinham como destino a cidade, marcando a sua identidade. Como "poderosa" e de "população ordeira, disciplinada e laboriosa", a capital paulista e os seus habitantes era não só exemplar para o país como simbolizava a absorção e a integração, "num só povo a todos e a cada um", ideal perseguido pelo próprio Vargas ao longo do período em que antes estava na presidência.

\footnotetext{
${ }^{217}$ MARINS, P. C. G. Op. cit., 1999, p. 30.

${ }^{218}$ VARGAS, G. apud MARINS, P. C. G. Op. cit., 1999, p. 30. De acordo com Marins, a transcrição do discurso foi publicada na íntegra no Diário da Noite de 25 jan. 1954. As intervenções constam do texto citado em Marins.
} 
A figura de Francisco Matarazzo Sobrinho como presidente da comissão responsável pelos festejos do quarto centenário de São Paulo, é interpretada por Marins, dentro do quadro delineado, como a expressão da "ascensão dos imigrantes ao universo simbólico comandado pelas elites dirigentes de São Paulo", inserção esta que se dá ao mesmo tempo em que, aos poucos, se dissolve toda a carga que trazia o mito bandeirante. Ainda de acordo com o autor, Matarazzo "era ao mesmo tempo o bandeirante ressignificado e o princípio do fim da alusão passadista". A ressignificação do bandeirante em Matarazzo, porém, talvez fosse mais necessária às velhas e decadentes elites do que ao próprio industrial. ${ }^{219}$

Para Marins, o Parque Ibirapuera, "de linhas modernas e modernistas tornava-se o novo marco zero da capital, refundando-a". ${ }^{220}$ Igualmente trabalhado por Marins (1999) e Lofego (2004), os sentidos da comemoração estavam sintetizados naquele que foi escolhido como o emblema, o selo oficial do grande evento: a "aspiral": no sentido de aspiração pelo futuro, para o alto. A "aspiral", como foi batizado por Matarazzo o desenho helicoidal de Zenon Lotufo e equipe, "funcionava como ícone de um monumento a ser erguido durante o IV centenário: a memória da grandiosidade de São Paulo". Projetava-se a cidade em crescimento, incontestavelmente registrada ao longo do conjunto de comemorações. ${ }^{221}$ Além disso, para Matarazzo o Ibirapuera tinha como destino a perpetuação da "grandeza da data do IV Centenário de São Paulo". 222

Diante do projeto enfim vencedor, pelo qual se batiam Matarazzo e outros atores, houve resistências e oposições em relação a construção dos pavilhões no Ibirapuera, empreendidas especialmente d'O Estado de S. Paulo, da revista Anhembi, de arquitetos e urbanistas, de professores da Universidade de São Paulo, dentre outros. Outros espaços eram aventados como mais viáveis, como o futuro campus da Universidade de São Paulo, na zona oeste, ou o centro de exposições do Anhembi, na zona norte. ${ }^{223}$ As modificações empreendidas no espaço da cidade, em torno ou não das atividades das comemorações do quarto centenário, bem como o incremento de espaços acadêmicos, culturais e artísticos e os investimentos na imagem e na

\footnotetext{
${ }^{219}$ MARINS, P. C. G. Op. cit., 1999, p. 30.

${ }^{220}$ MARINS, P. C. G. Op. cit., 1999, p. 33.

${ }^{221}$ LOFEGO, S. L. Op. cit., 2004, p. 175.

${ }^{222}$ Lofego, S. L. Op. cit., 2004, p. 76.

${ }^{223}$ A questão é explorada em BARONE, A. C. C. A oposição aos pavilhões do parque Ibirapuera (19501954). In: Anais do Museu Paulista, São Paulo, v. 17, n. 2, jul.-dez. 2009.
} 
propaganda da cidade para todo o país, aspiravam a consolidação de uma capital cultural brasileira, além de principal centro industrial, econômico e paradigma urbano. Um centro difusor da modernidade.

\section{Uma oca e uma exposição histórica}

No conjunto arquitetônico desenhado por Niemeyer e equipe para o Parque Ibirapuera receber as exposições em comemoração ao quarto centenário da fundação de São Paulo, uma edificação junto à entrada principal da mostra se destacava. De volumetria singular, o Palácio de Exposições, hoje chamado de Oca, "proporciona grande continuidade espacial e impressionantes perspectivas". Durante décadas, abrigou o Museu do Folclore e o Museu da Aeronáutica, que desocuparam o local na década de 1990, quando o local foi preparado para receber parte substancial da Mostra do Descobrimento, em comemoração aos 500 anos da chegada de Pedro Álvares Cabral, data-símbolo do nascimento do Brasil. Na atualidade, a Oca ainda é um dos principais espaços de exposições da cidade de São Paulo, e está sob administração, desde 2010, da Secretaria Municipal de Cultura. Além disso, a Oca integra o Museu da Cidade de São Paulo, conjunto de espaços museológicos articulados pela cidade. ${ }^{224}$

Foi nesse espaço de cerca de sete mil metros quadrados dispostos em dois pavimentos, cuja visualidade externa alude a construção indígena que, em 13 de setembro de 1954, menos de um mês após a inauguração do Parque Ibirapuera, foi solenemente aberta, para convidados, a Exposição de História de São Paulo no quadro da História do Brasil, sob a curadoria do Professor Jaime Cortesão, com o auxílio direto de Mário Neme, Ernani Silva Bruno e Hélio Damante. A equipe de colaboradores contou ainda com Agostinho da Silva, Antonio Pedro Rodrigues e Armando Cortesão, portugueses, e Darcy Ribeiro, Francisco Rodrigues Leite, Gastão Cesar Bierrenbach de Lima, João Cruz Costa, José Wasth Rodrigues, Luís Saia, Miranda Maria Esmeralda Martinelli, Salomão de Vasconcelos e Yan de Almeida Prado. ${ }^{225}$

\footnotetext{
${ }^{224}$ Disponível em: <http://www.museudacidade.sp.gov.br/oca.php>. Acesso em 1 jul. 2015.

${ }^{225}$ CORTESÃO, J. et al. Ficha técnica. In: __. Exposição de História de São Paulo no quadro da História do Brasil. Catálogo. Datil., 308 fl., [São Paulo], [1954/1955]. BNP/ACPC E25/Cx. 64, Pasta 20. Considerando as características deste documento, como a paginação independente, reiniciada em cada capítulo/seção, nas próximas citações a este título indicarei somente a seção referida e o total de páginas que compõem o segmento em questão.
} 
Como vimos no tópico anterior, Cortesão havia estado em Portugal durante cerca de seis meses, retornando ao Brasil em março de 1953 com os resultados de suas pesquisas em arquivos portugueses a pedido do Itamaraty e da CIVCCSP. Na ocasião, a documentação levantada pelo historiador tinha conseguido 44 cópias fotográficas de mapas, planos hidrográficos, planos e panoramas de cidades em dezoito de 30 arquivos consultados. Trabalho que deveria ter sido concluído antes, atrasou por conta da demora do envio de verbas. De acordo com Cortesão, aquela poderia ser considerada a maior missão a Portugal desde a independência do Brasil para recolher documentos cartográficos, muitos deles inéditos. ${ }^{226}$ No retorno, depois de se reunir em São Paulo com a Comissão, Cortesão escreveu a Sarmento Pimentel, que lhe respondeu incentivando-o, certo de que o historiador disporia de todas as condições para ter êxito em sua empreitada. Pimentel afirmava isto depois da conversa que tivera com Paulo Duarte. Em junho daquele ano, o historiador português assinou o contrato com a Comissão, então presidida por Francisco - Ciccilo - Matarazzo Sobrinho, contrato que estava previsto para ser encerrado em 25 de janeiro de $1955 .^{227}$

O jornal da família Mesquita, dando cobertura a tudo o que dizia respeito às comemorações, congratulou em julho de 1953 a escolha de Cortesão para a coordenação dos trabalhos da Exposição de História, afirmando que "em virtude de seus altos méritos e do profundo conhecimento que tem" da história brasileira, a escolha era "acertada". Conforme a reportagem não assinada, o historiador, "há mais de 30 anos" está concentrado sobre os assuntos da história do Brasil, "dedicando o melhor de seus esforços e publicando livros de indiscutível valor" sobretudo sobre os primeiros tempos do período colonial. Ao ressaltar as credenciais que teriam aberto os caminhos para que Cortesão fosse agraciado com a grande empreitada, o periódico salienta a participação do autor nas obras dirigidas por Malheiro Dias e por Damião Peres, e os textos que havia escrito sobre o Brasil desde os anos 1920 ainda na Europa. Dos trabalhos no Brasil, mencionam-se os cursos no Itamaraty, suas primeiras publicações e Alexandre de Gusmão, que à época estava com

\footnotetext{
${ }^{226}$ CORTESÃO, J. Memorandum para o Embaixador Lafayette de Carvalho e Silva. Cópia. Lisboa, 20 fev. 1953. BNP/ACPC E25, Pasta 10.

${ }^{227}$ CIVCCSP. Termo de Prorrogação de Contrato. São Paulo, 25 mar. 1955. BNP/ACPC E25/Caixa 64, Pasta 20. Pelo documento, Guilherme de Almeida, que assumiu a função de presidente da Comissão após a renúncia de Matarazzo - por conta das pressões vindas de Jânio Quadros prorrogou o contrato de Cortesão até 27 de agosto de 1955.
} 
cinco dos nove volumes lançados. Comenta-se ainda sobre a preparação de História do Brasil nos Velhos Mapas, a série publicada no próprio jornal sobre as bandeiras e os Manuscritos da Coleção De Angelis, com o primeiro volume publicado. ${ }^{228}$

Entre a reunião de Cortesão com a equipe de Matarazzo após o seu retorno de Portugal, quando apresentou os primeiros documentos cartográficos que aventou, e a divulgação de seu nome como organizador da Exposição de História passaram-se quase quatro meses. De acordo com a reportagem, Cortesão aceitou o convite depois da Comissão Executiva aprovar por unanimidade o plano da exposição, o qual, segundo o historiador português, pertencia "em germe" a Matarazzo. Cortesão ainda afirma ao jornal que hesitou "longamente" antes de se decidir, ciente da "grande, mas pesada honra decorrente de semelhante encargo". ${ }^{229}$ Como pudemos observar da correspondência de Sarmento Pimentel, para além das naturais declarações públicas de deferência à CIVCCSP, Cortesão buscava também assegurar-se das condições que teria para executar o seu plano com liberdade de ação.

Poucos dias após a assinatura do contrato, Sarmento Pimentel escreveu a Cortesão elogiando o programa para a exposição. Os elogios bastante suspeitos daquele que pode ser considerado o amigo mais presente de Cortesão, a julgar pela intimidade com que tratam os assuntos mais diversos nas muitas correspondências, também declara o feito do historiador como "novo padrão lusíada nas terras americanas". Pimentel ainda comenta da disposição da colônia portuguesa organizada, que se mobilizaria em todo o Brasil para financiar a "obra magnífica" do compatriota e outras homenagens à cidade. As ações do remetente continuam a demonstrar um verdadeiro gestor das relações de Cortesão, indicando-lhe pessoas e atitudes a tomar para bem realizar as suas atividades, além dele próprio providenciar as condições e as circunstâncias para Cortesão agir. ${ }^{230}$

De fato, a comunidade portuguesa organizada no Brasil se desdobrou para participar com relevo das comemorações. Em outubro de 1953, um encontro realizado no Gabinete Português de Leitura definiu como se daria a participação da colônia lusitana. Na presença de Matarazzo, o grupo, formado por sujeitos como

\footnotetext{
${ }^{228}$ Exposição da história de São Paulo nas comemorações do IV Centenário. Apresentação de documentos originais e inéditos dos arquivos nacionais e estrangeiros - A escolha do prof. Jaime Cortesão para organizar aquela seção nas festas de 1954. In: O Estado de São Paulo, São Paulo, 8 jul. 1954, p. 11.

${ }^{229}$ Exposição da história de São Paulo... In: O Estado de São Paulo, São Paulo, 8 jul. 1954, p. 11.

${ }^{230}$ PIMENTEL, J. S. Correspondência a Jaime Cortesão. São Paulo, 29 jun. 1953. BNP/ACPC E25/760.
} 
Sarmento Pimentel, Pinto Duarte, Ricardo Seabra, com núcleos no Rio de Janeiro e em São Paulo, predispôs-se a colaborar com a reprodução dos documentos necessários à exposição, os quais Cortesão já buscava na Europa, dispondo a verba total de nove milhões de cruzeiros para uma série de atividades, eventos, monumentos etc. Para além do nível de organização do grupo, compreende-se da atitude tomada pelo conjunto a importância que se dava ao fato de um português estar à frente da Exposição de História. ${ }^{231}$ Mesmo que outros indivíduos e comunidades de imigrantes se fizessem presentes, de alguma forma, nas celebrações, como o próprio Matarazzo, ítalo-brasileiro, a presença portuguesa dizia respeito a uma colônia que não tinha chegado há pouco tempo e que pretendia se firmar perante os demais. Tratava-se de uma comunidade que, como vimos no texto de Cortesão quando do lançamento de Clássicos e Contemporâneos, buscava recuperar as perdas que vinha acumulando frente às outras matrizes que se somavam à sociedade brasileira, tendendo a reduzir a importância ou desqualificar as "raízes portuguesas" do país. Em Portugal também havia um grupo organizado para prestar auxílio à organização da Exposição de História. Como consta em alguns documentos do arquivo de Cortesão e na imagem a seguir (imagem 1), registro do desembarque de materiais vindos de Portugal, havia uma "Comissão Portuguesa do IV Centenário de São Paulo".

${ }^{231}$ Federação das Associações Portuguesas. A participação dos portugueses do Brasil no IV Centenário da Fundação de S. Paulo. Rio de Janeiro, folheto impresso, 15 p., 1955. 


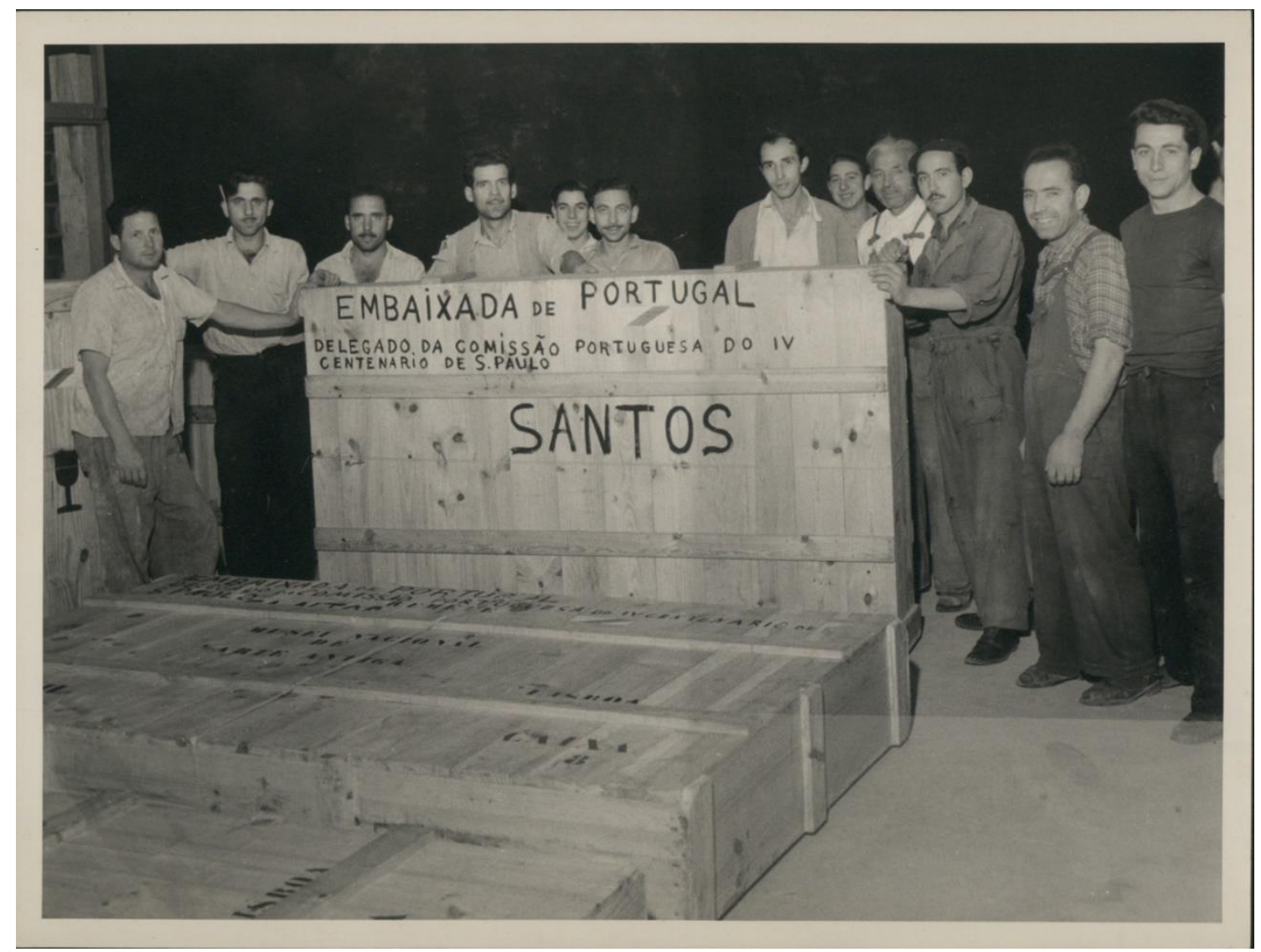

Imagem 1. Chegada de material para a Exposição de História. s/d., fotógrafo não identificado. BNP/ACPC E25/1489.

Segundo Tathianni Silva (2014), o piracicabano Mário Neme, intelectual do círculo das revistas Clima e Planalto, foi designado para participar da comissão organizadora dos festejos. Neme, por ser servidor público municipal, tornava-se um elo direto entre comissão e administração pública. Atuando como assistente direto de Cortesão, Neme foi o seu principal correspondente ao longo do período em que esteve na Europa. Ainda de acordo com a historiadora, Neme "passou a pensar e organizar juntamente com Cortesão os trabalhos da exposição", dialogando diretamente com Matarazzo e com dois historiadores locais: Hélio Damante e Ernani Silva Bruno. ${ }^{232}$

Nos preparativos da ida de Cortesão para a Europa, Mário Neme lhe escreve mediando um encontro entre Matarazzo e o organizador da exposição e comunicando o contato estabelecido entre Alice Canabrava e Ernani Silva Bruno, que deveriam auxiliá-lo nos trabalhos. Agostinho da Silva, que era professor em Pernambuco, deveria entrar em contato em breve. ${ }^{233}$ Em resposta, já de Lisboa,

\footnotetext{
${ }^{232}$ SiLVA, T. C. Op. cit., 2014, p. 80-81.

${ }^{233}$ NEME, M. Correspondência a Jaime Cortesão. São Paulo, 4 set. 1953. BNP/ACPC E25/Caixa 64, Pasta 20.
} 
Cortesão relata os seus primeiros dias em Lisboa, não sem antes reclamar da ausência de Matarazzo no encontro marcado. A pedido de Cortesão, Neme deveria se ocupar com os colaboradores das três últimas seções da exposição e tranquiliza-o em relação a Agostinho da Silva. O historiador se diz surpreso com a acolhida que the deu o Governo Português quando de sua chegada, comunicando que a presidência do Arquivo Histórico Ultramarino the havia dado livre acesso aos verbetes sobre a história de São Paulo que ainda estavam sendo preparados pela instituição. A mesma disposição diz ter encontrado do Arquivo Nacional da Torre do Tombo. Além disso, Cortesão comenta sobre o início das tratativas de encomendas artísticas e cedência de originais, assuntos sobre os quais escreveria circunstanciadamente a Matarazzo. Quanto à solicitação que Neme havia repassado dos "Rapazes da Arquitetura", provavelmente na expectativa de planejar a organização do pavilhão, Cortesão pede para que aguardem o levantamento de uma quantidade razoável de materiais arquivísticos e artísticos. ${ }^{234}$

Em correspondência posterior, Neme envia plantas do pavilhão para Cortesão e reclama de dificuldades colocadas pela Prefeitura. Sobre Alice Canabrava, o remetente comenta que problemas familiares estavam dificultando o contato entre ambos. Além disso, o escritor confessa hesitar em solicitar a revisão dos trabalhos à consultoria, sem, no entanto, explicitar o motivo. ${ }^{235} \mathrm{Na}$ resposta de Cortesão, o autor envia 40 páginas datilografadas com transcrições de documentos provavelmente inéditos e de interesse para a história de São Paulo. Diz que tem o projeto, até então esboçado, "de organizar com esses documentos uma coletânea subordinada ao título de Pauliceae Monumenta Historica, a imprimir pelo fundo da Colônia Portuguesa". ${ }^{236}$

Das descobertas, contatos e levantamentos feitos por Cortesão na Europa, além de notas que saíam na imprensa, nomeadamente n'O Estado de S. Paulo, a correspondência que enviou a Matarazzo em dezembro de 1953 fornece um amplo panorama sobre os seus deslocamentos e contatos. Prestando conta sobre seus serviços, realizados desde a sua chegada em setembro daquele ano, Cortesão diz ter encontrado "desde logo grande espírito de cooperação da parte do governo

\footnotetext{
${ }^{234}$ Cortesão, J. Correspondência a Mário Neme. Cópia. Lisboa, 21 set. 1953. BNP/ACPC E25/Caixa 64, Pasta 20.

${ }^{235}$ NEME, M. Correspondência a Jaime Cortesão. São Paulo, 30 set. 1953. BNP/ACPC E25/Caixa 64, Pasta 20.

${ }^{236}$ CORTESÃo, J. Correspondência a Mário Neme. Cópia. Lisboa, 10 out. 1953. BNP/ACPC E25/Caixa 64, Pasta 20. De fato, a coleção foi publicada sob o selo do Gabinete Português de Leitura. O primeiro volume foi publicado em 1956.
} 
português" para que tivesse êxito em sua tarefa, comentando sobre o que já havia comunicado a Neme sobre os arquivos da Torre do Tombo e do Ultramar. A documentação sobre São Paulo, destaca, havia sido organizada a pedido do governo luso, a título de contribuição com as comemorações centenárias. O historiador contou também com a disposição dos ministros dos Negócios Estrangeiros e da Educação, que nomearam junto às suas pastas pessoas responsáveis para mediar os empréstimos de obras e documentos por todo o país, dentre eles a Carta de Caminha e um quadro dos Reis Magos da Sé de Viseu, de 1506, onde um rei, comumente caracterizado como negro na iconografia religiosa, está de cocar.

Cortesão falou com "artistas portugueses especializados na organização de exposições para dar expressão original à parte mais estritamente portuguesa da Exposição Histórica de S. Paulo", constituindo para tanto um comitê formado "pelo melhor grupo de artistas daquela especialidade": Bernardo Marques e Manuel Lapa, sob a presidência do escultor Diogo de Macedo, diretor do Museu de Arte Contemporânea. O grupo solicitou, por intermédio de Cortesão, como condição prévia para os seus trabalhos o conhecimento do pavilhão e a formação de uma maquete do espaço que seria trabalhado por eles. Por isso mesmo, o historiador pediu urgência a Neme para o envio das plantas. O trabalho realizado pelos artistas já estaria bastante adiantado quando da volta de Cortesão dos outros países que visitou. Tudo o que fosse produzido seria ainda enviado a um decorador português residente no Rio de Janeiro, Artur Jorge, que por sua vez iria a São Paulo encontrar-se com o arquiteto Jacob Rusti, com quem se entenderia a respeito da execução do trabalho da exposição, podendo ainda estender seus serviços a outras seções além das que estavam sob direta responsabilidade de Cortesão.

Na sequência, Cortesão descreve o que havia feito em França, Holanda, Bélgica e Itália. Na capital francesa, por intermédio da embaixada brasileira, visitou arquivos e museus e apresentou uma lista de objetos a solicitar o empréstimo. De um alto funcionário do Ministério da Cultura francês, Cortesão disse ter sentido uma "discreta boa vontade" em atender aos pedidos, menos os da longa lista de mapas da Biblioteca Nacional, que mandou então fotografar. Extraoficialmente, o historiador encontrou-se com um colecionador e antiquário de suas relações e este se prontificou a emprestar pinturas de Post, Debret, J. A. Taunay, cenas a partir de Rugendas etc. O cedente apenas solicitava que se arcasse com os custos de transporte e seguro. Nos museus holandeses de Haia e Amsterdã, Cortesão conseguiu reproduções de retratos 
e de quadros, dentre os quais obras de Post. Não contou naquele país com oficiais da embaixada brasileira.

$\mathrm{Na}$ capital belga, Cortesão havia marcado encontro com Avelino Teixeira da Mota $^{237}$, oficial da Marinha Portuguesa encarregado pelo governo português de inventariar e reproduzir mapas antigos presentes em arquivos europeus referentes ao Brasil e às colônias portuguesas. A ele também se encomendara a organização de uma exposição em homenagem à cidade de São Paulo por seu aniversário. O Governo de Portugal incentivou o encontro entre ambos para que as exposições não se prejudicassem entre si. O encontro acabou não acontecendo, ficando em suspenso para quando Cortesão retornasse a Lisboa.

Em Roma, Cortesão foi assessorado pelas duas embaixadas brasileiras. Tinha a esperança de conseguir cópias de mapas no Vaticano por intermédio de Teixeira da Mota, o que assumiu ser bastante difícil. Tentou junto ao governo italiano outros originais, como o mapa de Cantino, retratos de Salvador Correia de Sá e Francisco Barreto, bem como fotocópias de documentos e mapas. As negociações, que haviam sido feitas na companhia do secretário da embaixada e de Sérgio Buarque de Holanda, encontraram bastante resistência. Uma viagem à Áustria que havia sido planejada foi cancelada, uma vez que as aquarelas de Thomas Ender haviam sido conseguidas, conforme lhe informaram de São Paulo. Cortesão, por fim, pede que se estenda a sua permanência em Portugal para poder acompanhar os processos de empréstimo e conclusão das atividades relacionadas à exposição. ${ }^{238}$

Nota-se na correspondência o empenho do governo salazarista em participar com relevo das comemorações centenárias de São Paulo, o que seguramente não é vazio de significado. A grandiosidade do evento era uma oportunidade sem tamanho para divulgar as "raízes lusas" da capital paulista e do Brasil, ainda mais tendo um português, mesmo que oponente no campo político, à testa de uma exposição histórica. Aquele governo era exemplar em relação ao uso da linguagem das exposições para fazer propaganda do regime e da "raça" portuguesa, como veremos

\footnotetext{
${ }^{237}$ Avelino Teixeira da Mota e Armando Cortesão, irmão de Jaime, organizaram a Portugaliae Monumenta Cartographica, publicada em 1960 na esteira das comemorações centenárias da morte de D. Henrique.

${ }^{238}$ CORTESÃO, J. Correspondência a Francisco Matarazzo Sobrinho. Cópia. Lisboa, 5 dez. 1953. BNP/ACPC E25/Caixa 64, Pasta 20. Ainda que Ciccilo Matarazzo tenha acompanhado o planejamento e a montagem da exposição, a presidência da CIVCCSP estava a cargo do poeta Guilherme de Almeida quando da sua abertura em setembro de 1954. Entretanto, não há registros de troca de correspondência entre ambos no espólio Jaime Cortesão.
} 
adiante. Além disso, as relações de Cortesão em Portugal, como não poderia deixar de ser, e na França se mostraram fundamentais para a cessão de objetos.

O empenho não quer dizer, entretanto, que Cortesão passava a ser visto como um amigo do Governo de Portugal. A correspondência com o amigo David Ferreira indica que os olhos da polícia salazarista estavam sobre Cortesão. Ainda que nas primeiras, em que Ferreira agradece a indicação do amigo para ser um colaborador das comemorações paulistanas, ficando responsável por administrar as finanças de Cortesão naquele período e intermediar negociações relativas à exposição, em uma missiva de março de 1955, o remetente solicita que Cortesão não torne a pôr nem o seu nome, nem utilizar sobrescritos e impressos que aludam à CIVCCSP, além de tomar outras medidas de segurança.

Segundo Ferreira, as correspondências vinham chegando com sinais de violação ou com atrasos anormais. Não raro, compareceu aos Correios e foi forçado a declarar, depois de ler abertamente a carta aos funcionários, que nada lhe faltava. Levantando ainda assim a hipótese de coincidências desagradáveis, sugere que além das precauções, remeta as correspondências sob o nome de solteira de sua esposa, Carolina Ferreira, endereçadas também a Teresa Ferreira, esposa de David. Ademais, David Ferreira ainda pede que Cortesão não permita que saibam em Portugal de seu desejo de retornar, "caso se torne possível realizar tal desejo", incentivando-o ainda a manter a sua residência no Brasil. ${ }^{239}$

George Agostinho da Silva (1906-1994), dos círculos intelectual e familiar - o seareiro também radicado no Brasil era casado com a filha de Jaime, Judith Cortesão (1914-2007) - atuou diretamente na organização da exposição. Segundo Gilson Brandão de Oliveira Júnior (2010), o pensamento de Agostinho da Silva, fortemente marcado pelas influências de Jaime Cortesão, Gilberto Freyre e Antonio Sérgio, teve grande peso em suas concepções quando da criação do Centro de Estudos AfroOrientais (CEAO), na Bahia, quanto na área das relações internacionais. Silva tinha vivido experiências muito semelhantes às de Jaime Cortesão na Seara Nova, na França, na Espanha e no Brasil. ${ }^{240}$ Trabalhando de longe e de perto das atividades de Cortesão, Agostinho da Silva e Judith Cortesão colaboraram na edição de Alexandre de Gusmão e o Tratado de Madrid (1750). O casal morava em João Pessoa, onde

\footnotetext{
${ }^{239}$ FERREIRA, D. Correspondências a Jaime Cortesão. Lisboa, 1 set. 1953; 4 mar. 1954; 13 mar. 1955. $\mathrm{BNP} / \mathrm{ACPC} \mathrm{E} 25 / 465-469$.

${ }^{240}$ OliveIRA JR., G. B. Op. cit., 2010, p. 110.
} 
Agostinho da Silva era professor da Universidade da Paraíba, da qual se licenciou durante um curto período para poder acompanhar a organização da Exposição de História. A cooperação entre ambos não se restringe a essas atividades, no entanto, e voltarei a tratar dessa relação no próximo capítulo. ${ }^{241}$ De acordo com o que consta em nota n'O Estado de S. Paulo, o "professor Agostinho da Silva" era um dos encarregados da Exposição de História que ficavam no Ibirapuera e recebiam os telefonemas de quem quisesse se informar sobre como agendar visitas especiais, como para grupos escolares. ${ }^{242}$

O fato de Cortesão estar trabalhando com a documentação cartográfica desde os tempos de sua residência em Paris, perspectiva que se torna ainda mais relevante após o seu ingresso como consultor e depois como professor no Ministério das Relações Exteriores, por si só, seriam suficientes para compreender a cartografia histórica como linha mestra da Exposição de História. Além disso, no entanto, a relação com a cartografia também estava presente no ambiente familiar, pois o historiador tinha como irmão e grande interlocutor e colaborador Armando Cortesão (1891-1977), funcionário da UNESCO que também trabalhava com fontes cartográficas. Junto de Avelino Teixeira da Mota, Armando Cortesão trabalhou na recolha e organização de mapas, planos e outras fontes afins sobre Portugal, Brasil e as então colônias portuguesas, publicando posteriormente esse material como parte das comemorações ao quinto centenário da morte do Infante D. Henrique. O irmão também colaborou para a execução da exposição, assim como tinha auxiliado o autor quando da produção de Alexandre de Gusmão e o Tratado de Madrid (1750).

Segundo constava em reportagem já citada anteriormente, a respeito da chegada de Cortesão com o material cartográfico que havia recolhido tanto para o trabalho encomendado pelo Itamaraty quanto para o levantamento solicitado pela Comissão do Quarto Centenário, intentava-se realizar uma Exposição de Cartografia Antiga de São Paulo, certamente porque Cortesão já era notório nessa área no país. Em se tratando a integração, o espaço, o território os assuntos mais importantes naquele contexto, e em se considerando o papel que São Paulo já desempenhava na produção de Cortesão, sobretudo por meio dos bandeirantes, bem como o papel que essa história representava para as leituras que se faziam do ingresso do país na

\footnotetext{
${ }^{241}$ SiLVA, A. Correspondências a Jaime Cortesão. João Pessoa, 4 mai. 1953; 18 ago. 1953. $\mathrm{BNP} / \mathrm{ACPC} \mathrm{E} 25 / 1022 ; 1025$.

${ }^{242}$ Exposição de História. In: O Estado de S. Paulo, São Paulo, 1 out. 1954, p. 15.
} 
modernidade, passo agora para a análise da Exposição de História de São Paulo no quadro da História do Brasil, interpretando-a à luz dos trabalhos realizados por Cortesão no país, especialmente a partir do texto que foi publicado no ano de 1955, A fundação de São Paulo: capital geográfica do Brasil. Primeiramente, vejamos essas duas chamadas publicadas na imprensa, na expectativa da abertura da Exposição de História para o público:

a Comissão do IV Centenário da Cidade de São Paulo anuncía a

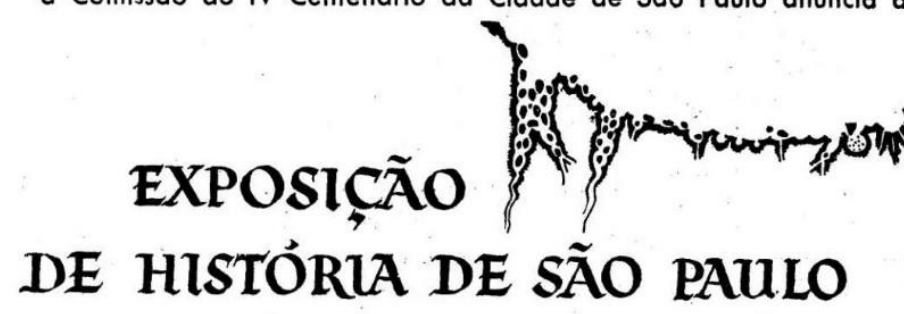

no quadro da História do Brasil
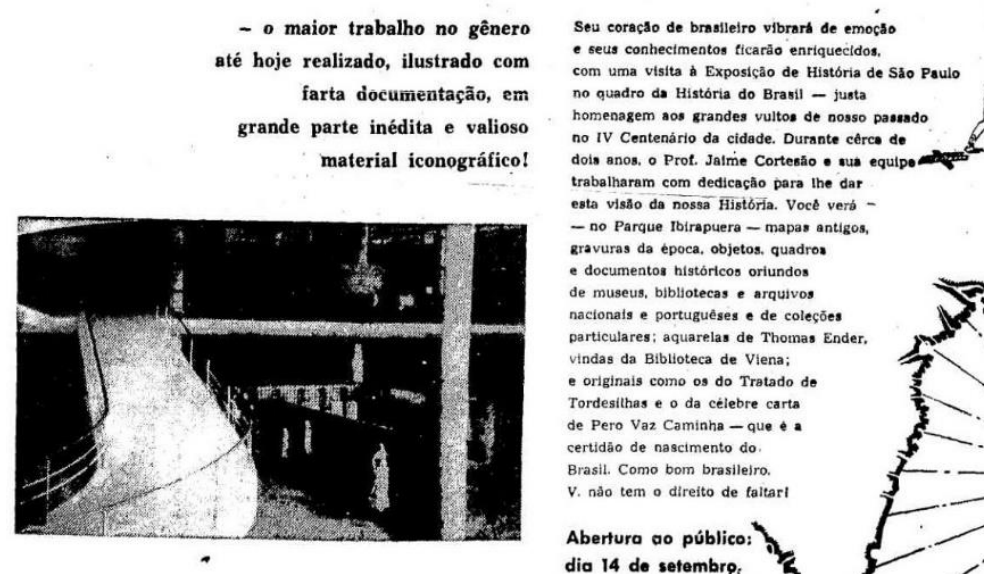
com uma visita di Exposiçăo de História de homenagem aos grandes vultos de nosso passado no IV Centenário da cidade. Durante cérce de trabalharam com dedicaçấo para the dar esta visåo da nossa História. Você verá - no Parque Ibirapuera - mapas antigos, gravuras da epoca, objetos, quadros e documentos histéricos oriundos de museus, bibllotecas e arquivos nacionals e portuguêses e de coleḉes
particulares: aquarelas de Thomas Ender. particulares: aquarelas de Thomas Ender. vindas da Biblioteca de Viena; e originais como os do Tratado de de Pero Vaz Caminha - que e a de Pero Vaz Caminha - que
certidâo de nascimento do. Brasil. Como bom brasileiro. v. nầ tem o direito de taltarı Abertura ao público: dia 14 de setembro. no Parque Ibirapueral

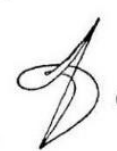

COMISSÃo do IV CENTENÁRIO da CIDAde de SÃo PAULO

Rua 24 de Maio, 250 - São Paulo - Brosil

Imagem 2. Anúncio da Exposição de História de São Paulo no quadro da História do Brasil. In: O Estado de S. Paulo, 10 set. 1954, p. 8.

O anúncio da exposição (imagem 2), a quatro dias de sua abertura para o público, utilizava dois recursos para despertar o olhar: uma fotografia de uma parte interna do Palácio de Exposições, destacando a rampa, e o contorno do mapa de Lopo Homem de 1519, com o destaque de alguns índios trabalhando na derrubada de pau-brasil. A rosa-dos-ventos compõe com o mapa. A "aspiral", emblema oficial dos festejos, figura ao lado da identificação completa da Comissão. Acima da fotografia, o texto de chamada ressalta a singularidade e a grandiosidade daquele evento: "o maior trabalho do gênero já realizado, ilustrado com farta documentação, 
em grande parte inédita e valioso material iconográfico!". Em evidência, passado e futuro, representados respectivamente pelo mapa e pela arquitetura modernista, fazem um apelo ao "coração de brasileiro", que "vibrará de emoção" e terá os seus conhecimentos "enriquecidos" pela visita àquela que era uma "justa homenagem aos grandes vultos do nosso passado".

Ao que se pode identificar da propaganda, não se apela para identidades regionais e sim para o "coração de brasileiro", ratificando a leitura de Marins acerca dos símbolos da identidade paulista. O próprio mapa, ocupando pelo menos a metade do campo do quadro, alude ao país, quadro no qual se insere a história paulista. No texto ainda, destaca-se o tempo dedicado por Jaime Cortesão e sua equipe para darem ao desejado visitante "esta visão da nossa História". Elencando os objetos que serão expostos ao público, a lista é iniciada pelos "mapas antigos" e concluída com os carros-chefes da exposição, utilizados - recurso frequente ainda nos dias hoje - para atrair o público. Verdadeiros monumentos, para usar a concepção de Le Goff, os originais do Tratado de Tordesilhas e a Carta de Caminha, "certidão de nascimento do Brasil", assim como as aquarelas de Thomas Ender vindas de Viena figuram como objetos imperdíveis aos olhos do público. O ineditismo e a excepcionalidade daquele evento, pleno de monumentos, não dava a nenhum "bom brasileiro" o "direito de faltar".

O segundo anúncio (imagem 3) destaca a arquitetura do pavilhão onde aconteceria a exposição, a ser aberta naquele mesmo dia. Muito provavelmente, esse recurso de propaganda serviria para situar o visitante ao chegar ao grandioso parque onde aconteceria a mostra. Em vez de "no quadro da História do Brasil", o texto indica a leitura de "Exposição de História de São Paulo no Parque Ibirapuera!". O destaque do local do evento provavelmente servia à mesma finalidade da figuração da Oca e de parte da marquise repleta de silhuetas humanas - fixar a informação do local em que se daria o acontecimento. Sobre o parque muito se comentava na imprensa ${ }^{243}$, mas ainda era uma novidade no espaço urbano, tendo sido inaugurado menos de um mês antes da abertura da exposição, em 21 de agosto de 1954.

\footnotetext{
${ }^{243}$ De acordo com Lofego (2004, p. 81-98), o Parque Ibirapuera, além de ser bastante explorado pela iconografia das comemorações, figurando tanto em anúncios da CIVCCSP quanto nas propagandas de indústria e comércio, era fonte de preocupação e pessimismo por conta dos sucessivos atrasos nas obras.
} 
Um desfile inédito da História de São Paulo, no quadro da História do Brasil!

\section{Hoje, abertura ao público}

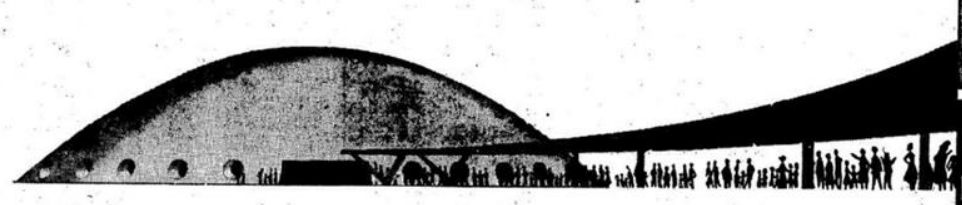

EXPOSIÇÃO
DE HISTÖRIA

DE SÃO PAULO

no Parque Ibirapuera!

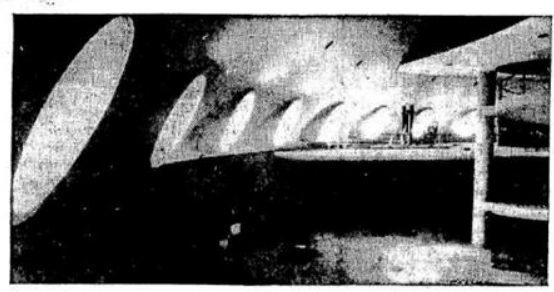

COMISSÃo do IV CENTENÁRIO DA CIDADE DE SÃo PAULO Rua 24 do Maia, 250 - Sso Pavio - Brosil
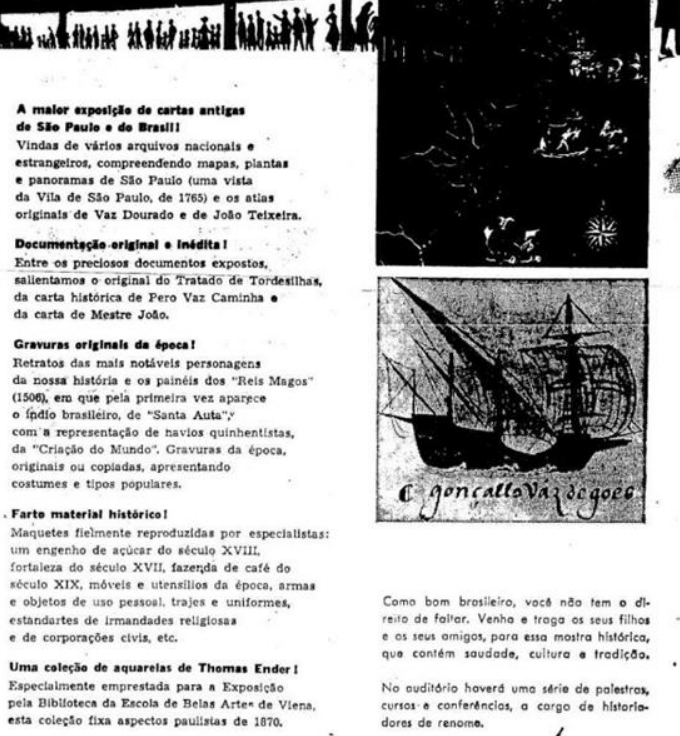

Como bom brositiero, voce neso tem o dll-

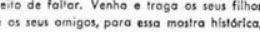

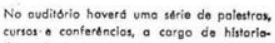

Imagem 3. Um desfile inédito da História de São Paulo, no quadro da História do Brasil! In: O Estado de S. Paulo, 14 set. 1954, p. 9.

Uma fotografia interna do pavilhão, destacando os efeitos de iluminação das janelas, alude ao futuro. Três quadros com documentos antigos são os representantes do passado. O texto, no centro, destaca em primeiro lugar "A maior exposição de cartas antigas de São Paulo e do Brasil!", marcando mais uma vez a preponderância desse tipo de documento no conjunto da exposição; dos documentos originais e inéditos, destacam-se os mesmos monumentos de Caminha e Tordesilhas e ainda a "carta de Mestre João"; das gravuras, menciona-se o painel português quinhentista dos reis magos em que pela primeira vez figura um índio; por "farto material histórico", entendem-se as maquetes de engenho, fortaleza, fazenda de café além de móveis, vestimentas e objetos de uso pessoal. Por fim, as aquarelas de Thomas Ender dão o destaque final: a joia emprestada pelo Museu de Belas Artes de Viena. Novamente, o apelo ao "bom brasileiro" que "não tem o direito de faltar" à exposição deve vir e trazer "os seus filhos e os seus amigos".

No entanto, a Exposição de História não estava sozinha. Compondo o cenário do novíssimo parque com os seus impressionantes pavilhões, a I Feira Internacional de 
São Paulo, aberta, com atraso, dois meses depois da inauguração da exposição de Cortesão, anunciava a capital paulista como "a Meca do mundo". Comércio, indústria e agricultura brasileiros desfrutariam de um momento sem igual para "o desenvolvimento de suas atividades", junto das "mais modernas produções" de "poderosas firmas de todos os continentes". Como o nome sugere e o texto diz, o espaço será de transações comerciais, um grande mercado instalado nos pavilhões "da Indústria", "do Comércio", "da Agricultura", "das Nações", "dos Estados”. O texto do chamado ainda ressalta que "peritos econômicos preveem que essa Feira Internacional, num momento em que nosso país está procurando interessar o capital estrangeiro, será a grande oportunidade para o nosso desenvolvimento econômico". O espaço do Parque Ibirapuera era preenchido assim por celebrações dos feitos do passado local e nacional - a tradição -, por meio da Exposição de História, e da modernidade, por meio da viva atividade industrial, comercial sem fronteiras, proporcionando intercâmbio de capital.

De tal modo, o Ibirapuera da década de 1950 estava em sintonia com a forma pela qual as sociedades industriais já há cerca de um século faziam-se observar e admirar: as grandes exposições. De acordo com Heloisa Barbuy (1999), as grandes exposições "universais", realizadas desde o início da segunda metade do século XIX e cujo apogeu foi vivido entre os últimos anos daquele século e os primeiros do seguinte, eram dedicadas não somente à venda de produtos. Segundo a autora, aquelas exposições vendiam

a ideia da sociedade industrial, do progresso material como caminho de felicidade, no qual todos deveriam congraçar, em harmonia universal; o sonho hegemônico, enfim, da classe burguesa. O que se vendia - sim - era um gênero de vida, uma construção política e ideológica, e visões de uma sociedade futura idealizada. ${ }^{244}$

A exibição das benesses da industrialização e o autoelogio das conquistas da inteligência humana conjugavam-se numa complexa teia de espetáculos, incluindo museus, teatros, atrações populares, vitrines comerciais. A visão era estimulada das mais diversas formas, causando admiração, maravilhamento. O visitante-espectador apreendia, visualmente, uma infinidade de elementos dispostos de modo a representar o que se supunha como realidade. ${ }^{245}$

\footnotetext{
${ }^{244}$ BARbUY, H. A exposição universal de 1889 em Paris: visão e representação na sociedade industrial. São Paulo: Loyola, 1999, p. 40.

${ }^{245}$ BARBUY, H. Op. cit., 1999, p. 50.
} 
Se no auge das exposições universais, nos tempos da Belle Époque, os avanços introduzidos pela industrialização davam sentido à dominação imperial/colonial e à exploração de recursos naturais, constituindo assim também um sentido da história da humanidade e das relações entre povos e com o ambiente ${ }^{246}$, guardadas as devidas proporções de tempo e espaço, a "história de São Paulo no quadro da História do Brasil" extravasa as escolhas museológicas do interior da Oca e se articula com toda a atmosfera que envolve o Parque Ibirapuera, a Feira Internacional e as próprias modificações do tecido urbano paulistano. Ao lado do principal portão de entrada, o Palácio de Exposições e a narrativa histórica nele contida poderia transformar o olhar do visitante que optasse por prosseguir com o seu passeio visitando outros pavilhões do parque. Mesmo se o percurso fosse o oposto, a visualidade do espaço interno poderia ainda sensibilizar o olhar para o entorno, composto por monumentos como o obelisco do Mausoléu dos "Heróis de 1932" e o Monumento às Bandeiras, bem como para os diversos signos da cidade em transformação com os quais o visitante se depararia no seu deslocamento até aquele espaço da zona sul da capital. O momento de balanço encetado pela imensa gama de atividades e intervenções planejadas para comemorar os quatrocentos anos da fundação da capital paulista tinha, no Parque Ibirapuera, a sua maior e mais eficaz síntese: amalgamavam-se projeções de um futuro moderno, de um presente digno de celebração e de uma narrativa épica do passado.

\footnotetext{
${ }^{246} \mathrm{O}$ clima de competição entre as potências imperiais europeias de então fazia-se representar naquelas exposições. Àquela época, a corrida imperialista, apoderando-se de recursos dos continentes africano, asiático e oceânico, culminaria nos grandes conflitos mundiais (THOMAZ, 2002, p. 202-203).
} 
durante 35 dias, São Paulo será a Meca do mundol

\section{FEIRA INTERNACIONAL DE SÃ̃ PAULIO}
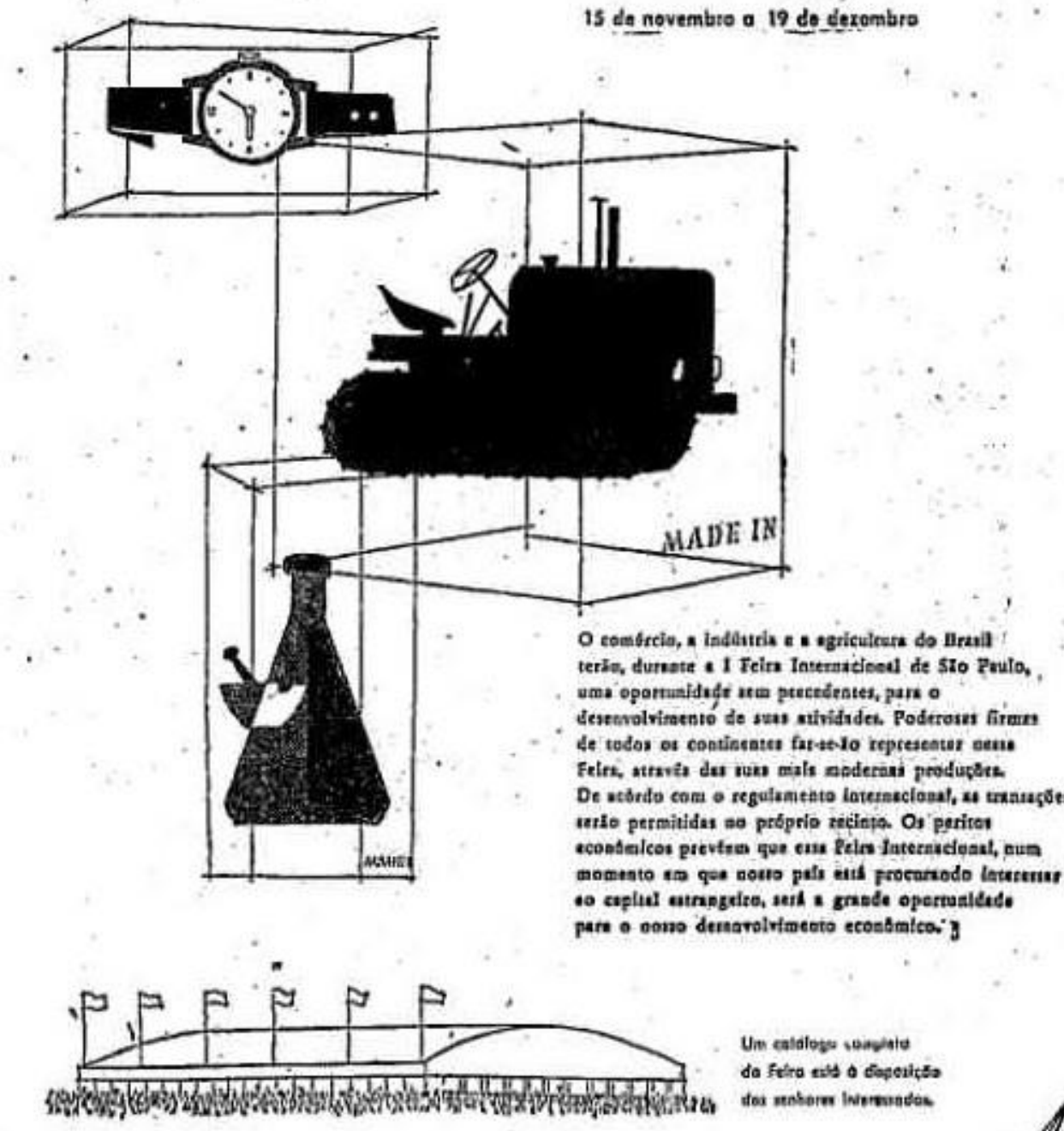

- comissão do iv centenario da cidade de são paulo

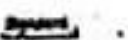

too 24 ido Malo, 250 - 500 Foulo - Braul

Imagem 4. I Feira Internacional de São Paulo. In: O Estado de S. Paulo, 14 nov. 1954, p. 8.

A Exposição de História de São Paulo no quadro da História do Brasil foi pensada por Cortesão e pela equipe por ele coordenada em nove seções. ${ }^{247}$ As seis primeiras ficaram sob a direção direta do historiador. As três finais estiveram a cargo de Ernani Silva Bruno, Hélio Damante, Mário Neme e Agostinho da Silva. Em artigo assinado

247 Segundo a reportagem d'OESP de 8 jul. 1954, anteriormente citada, em que Cortesão é entrevistado, a exposição teria a princípio dez seções. 
por Jaime Cortesão n'O Estado de S. Paulo, lia-se o que concebeu como sendo o "Plano Geral" daquela mostra:

Em vez d'um cerzido de anedotas e episódios mais ou menos pitorescos, imitando as histórias em quadrinhos e as consabidas gravuras de certos compêndios escolares, propusemo-nos pois a organizar um panorama síntese da História de São Paulo como decorrência lógica e orgânica de fatores geopolíticos, étnicos e culturais dando relevo e expressão viva à estrutura urbana de São Paulo e a os fatos capitais que marcaram a sua contribuição fundamental para a formação geográfica e política do Brasil. ${ }^{248}$

De acordo com a concepção de Cortesão para a mostra, pretendia-se um olhar menos convencional e factual, própria de "certos compêndios escolares" comparados a histórias em quadrinhos, para narrar a história de São Paulo, dando ênfase uma perspectiva que favorecesse a síntese a partir da compreensão de fatores e processos que explicariam os rumos da história local bem como marcariam a sua singularidade no quadro da história, da geografia e da política brasileiras. O texto acima fez parte de uma série sobre a exposição assinada pelo próprio Cortesão. Frequentemente foi por meio desse veículo que o autor respondeu às críticas que recebeu. Um pequeno impresso de 29 páginas, chamado de "Guia para o Visitante" (imagem 5), assinado pela Comissão e com o emblema da aspiral na capa, indicava que aquela era uma "homenagem ao IV centenário da fundação de São Paulo e aos homens que construíram a grandeza de nossa pátria". Segundo o folheto, em cada uma das nove seções "mostram-se os principais acontecimentos e vultos das várias fases da formação do nosso povo". Passemos a elas.

${ }^{248}$ CORTESÃO, J. A Exposição Histórica, 1. O Plano Geral. O Estado de S. Paulo, São Paulo, 13 mar. 1955, p. 9. 


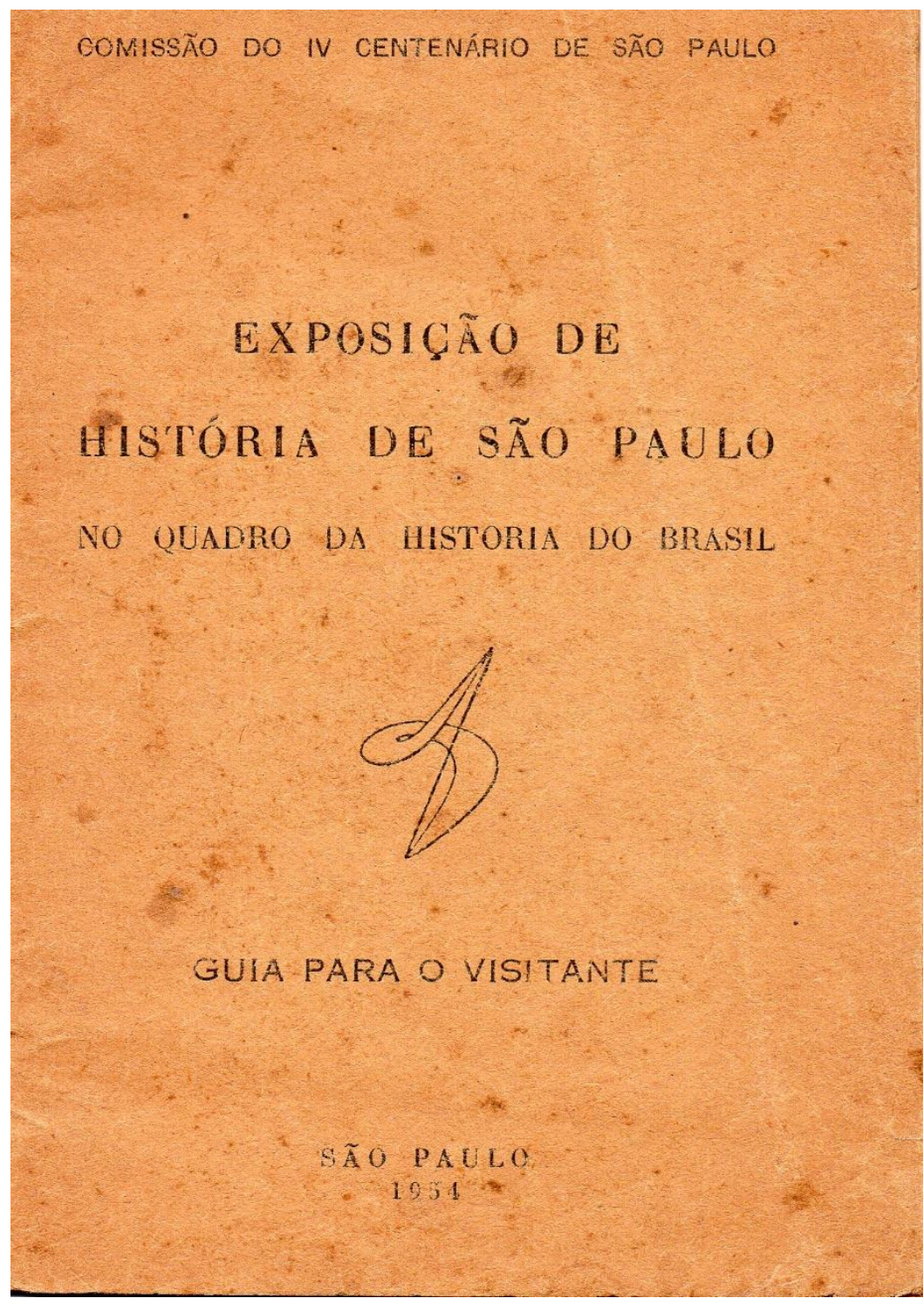

Imagem 5. Folha de rosto do Guia para o Visitante. Exposição de História de São Paulo no quadro da História do Brasil. CIVCCSP, São Paulo, 1954. 


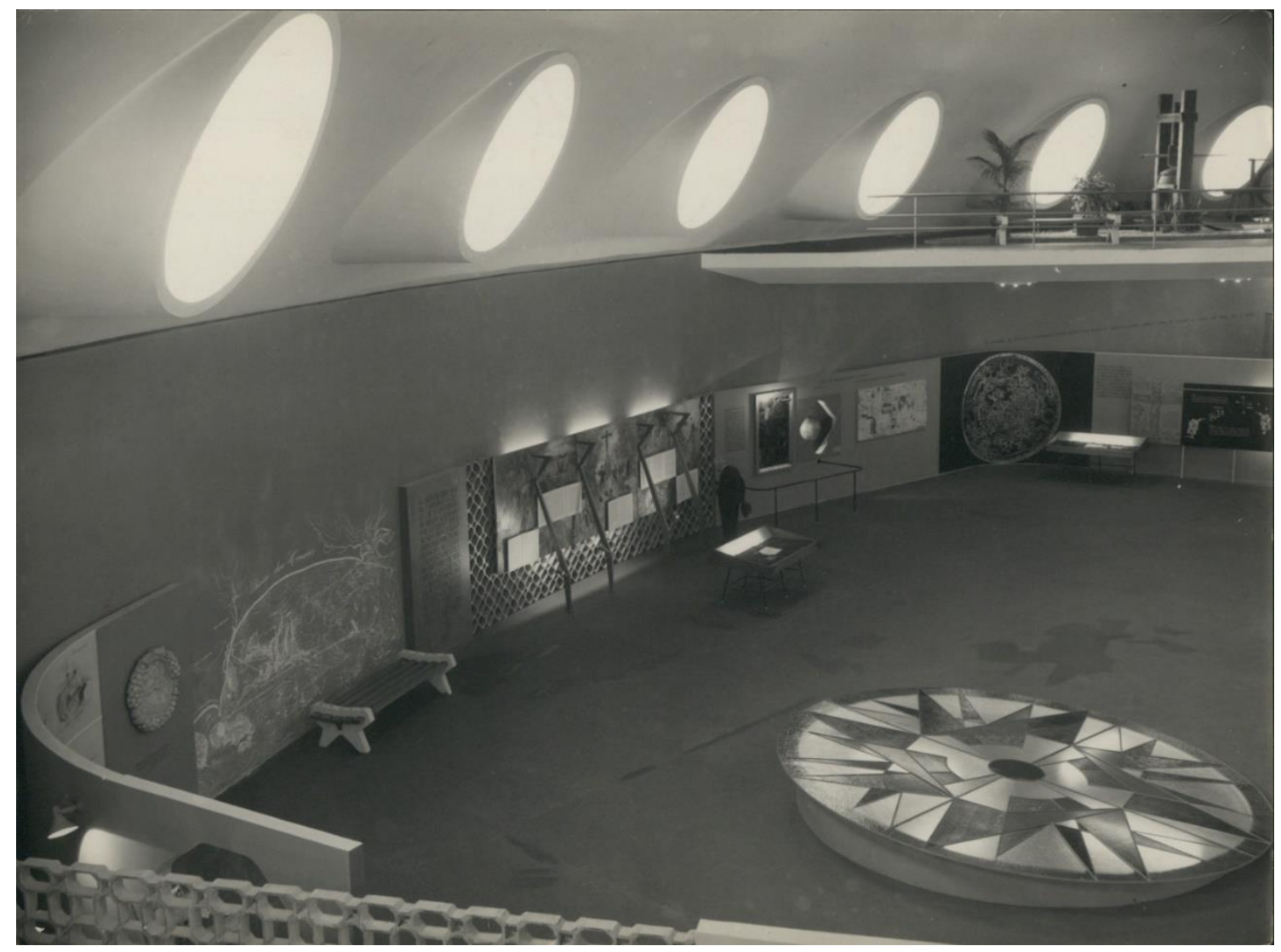

Imagem 6. Aspecto da Seção I - O Descobrimento dos Litorais. São Paulo, 19 out. 1954. Fotógrafo não identificado. $B N P / A C P C E 25 / 1502$.

A seção de abertura da narrativa da História de São Paulo no quadro da História do Brasil está diretamente inserida no quadro da história das navegações portuguesas. ${ }^{249}$ Com 12 painéis e sete vitrines, a seção com menos objetos expostos ${ }^{250}$ traz, no entanto, algumas das mais anunciadas peças da mostra: os originais do Tratado de Tordesilhas, em espanhol; da Carta de Caminha, em vitrine nomeada como "Auto do Nascimento do Brasil" e da Carta de Mestre João, primeira figuração da constelação do Cruzeiro do Sul. Documentos estes emprestados pelo Arquivo Nacional da Torre do Tombo, um dos principais cedentes de peças para a exposição.

Como a imagem acima (imagem 6) sugere, a exposição constituía um contínuo, com os painéis e as vitrines dispostos lado a lado. Conforme o catálogo, o

\footnotetext{
${ }^{249}$ CORTESÃO, J. et al. Seção I - O Descobrimento dos Litorais. In: Op. cit., [1954/1955], $17 \mathrm{p}$ ${ }^{250}$ Considero por objetos expostos todas as peças que compõem a mostra, independentemente de serem originais ou reproduções. Percebidas aqui em sua disposição no percurso e em conjunto com as legendas, que apresentam e dão sentido a objetos, a grupos de objetos ou a seções, essas peças serão descritas e analisadas de modo a identificar o universo ao qual elas pretendem fazer aceder o visitante (DEVALLON, 2009, p. 24-25).
} 
aspecto fotografado é de um dos lados da "sala" da primeira seção, no qual figura em destaque uma rosa-dos-ventos estilizada em vidros coloridos e iluminada de dentro. A imagem indica uma linha progressiva entre os painéis e vitrines, compondo uma sequência temática e cronológica. Em se considerando isto, o ponto inicial de toda a mostra era a "Partida das naus do Restelo" e a "chegada das naus ao Brasil", representada por um mural de Manuel Lapa (imagem 7), artista modernista português, que participou ativamente de todos os trabalhos junto de outros artistas modernistas. Com as embarcações no centro do mural, marcam-se do lado esquerdo alusões ao embarque em Lisboa e do lado direito o desembarque no Brasil, figurando dois indígenas ao lado o que parece ser um padrão de descoberta.

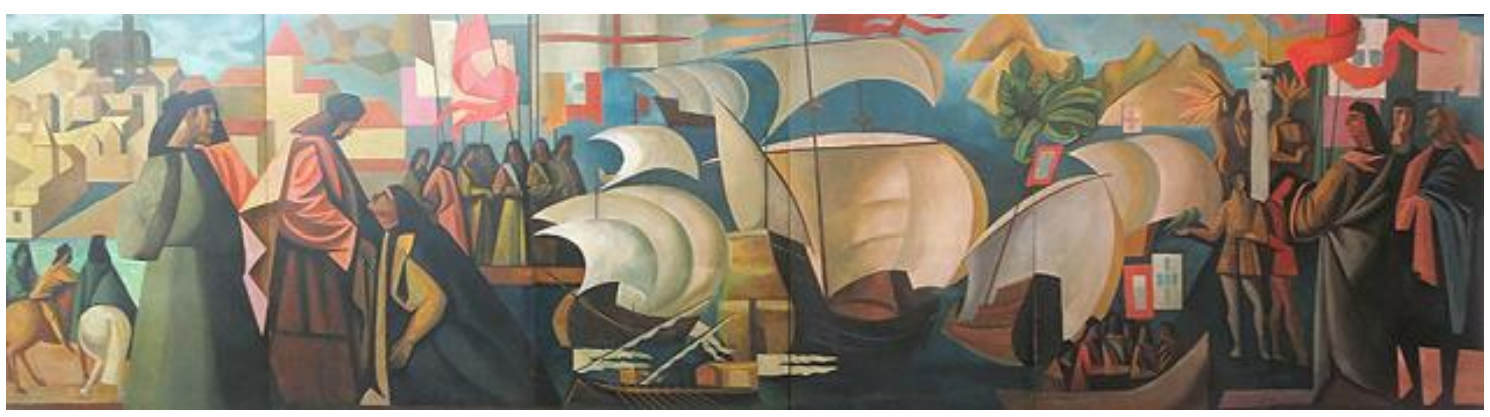

Imagem 7. Mural de Manuel Lapa. In: MARTÍ, S. Mural esquecido de 1954 é descoberto atrás de uma parede falsa na Oca. Folha de S. Paulo, São Paulo, 13 jul. 2015. (Imagem da Coleção de Arte da Cidadel CCSP).

Em seguida, a epopeia das descobertas também está representada nos retratos e esculturas do Infante "navegador" D. Henrique, de São Vicente, de D. Manuel e do Infante Santo D. Fernando (imagem 8). De acordo com o texto das legendas que acompanham estes vultos, São Vicente é identificado enquanto patrono dos descobrimentos e da "primitiva grei paulista", por ter sido o orago da primeira capitania. 


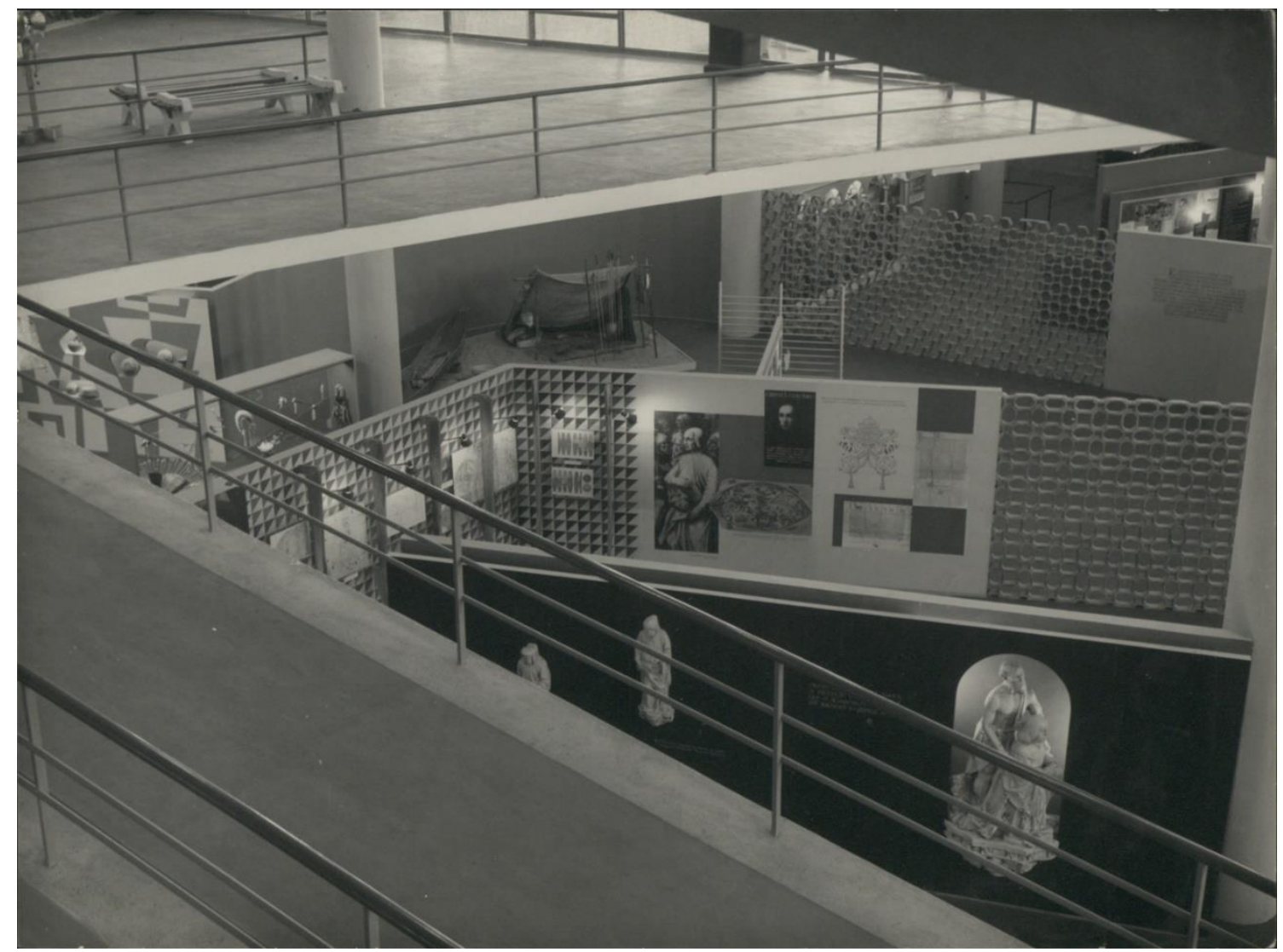

Imagem 8. Aspecto da Exposição. Partes da Seção I vistas de cima. São Paulo, s/d. Fotógrafo não identificado. BNP/ACPC E25/1505.

Cartas quatrocentistas, anteriores à chegada dos portugueses, põem em questão as primeiras aparições da "Ilha Brasil" bem como as negociações que culminariam na assinatura do Tratado de Tordesilhas em 1494. O percurso apresentava os registros que paulatinamente constituíam novas imagens cartográficas do mundo que se ia conhecendo, trazendo por exemplo o planisfério de Cantino (1502) - primeiro seguramente datado em que figura o Brasil - e o globo de Martinho de Boêmia (1492), ambos expostos no sexto painel cujo nome era "representação da grande revolução geográfica produzida pelos descobrimentos de Colombo e Cabral". No texto introdutório do catálogo, é dito que a primeira seção da mostra esboça um quadro representativo das atividades de portugueses e também de espanhóis na América.

Além disso, a primeira seção apresentava aspectos do surgimento do Brasil enquanto iconografia, visível sobretudo na pintura e na cartografia. Tema da segunda conferência de Cortesão realizada em São Paulo em dezembro de 1940, a pintura Adoração dos Reis Magos (imagem 9) é inserida na narrativa como expressão plástica do "sentido ideal da colonização portuguesa: a inclusão do aborígene do Brasil na 
cristandade", conforme consta da legenda que acompanha o quadro emprestado pelo Museu Grão Vasco, de Viseu. Catorze anos antes da exposição do original na Oca do Ibirapuera, a pintura que traz um índio como o rei mago Baltazar no lugar em que a iconografia cristã frequentemente representa um negro, foi caracterizada por Cortesão no auditório d' $A$ Gazeta como sendo a representação pictórica mais antiga "do Brasil". Segundo o historiador, a pintura foi encomendada pelo bispo de Viseu, que estaria a par das políticas expansionistas da Coroa. Para Cortesão, somente a encomenda por esta autoridade justificaria o ponto de vista representado na pintura, da "iniciação em Cristo" do Brasil e do Novo Mundo. Naquela ocasião, o intelectual português apresentava também ao público outro documento manuelino que anos depois figuraria na seção inicial da Exposição de São Paulo, a Carta de Lopo Homem (1519), a primeira descrição "completa" do trecho do litoral sul-americano correspondente ao Brasil. ${ }^{251}$

A constelação do Cruzeiro do Sul teve na seção um painel em que se apresentaram figuras e fotocópias de gravuras antigas representando observações dos polos por meio de instrumentos de navegação como o astrolábio e a balhestilha. Considerado como "desde logo o símbolo da nova grei", o Cruzeiro do Sul já tinha merecido a atenção de Cortesão em seus textos. Em um dos seus escritos, o autor dá a saber que teve contato com o que identifica como os primeiros registros da constelação, feitos por João de Lisboa e André Pires nos Livros de Marinharia, nos arquivos de Paris. ${ }^{252}$

A "mais bela carta quinhentista do Brasil" segundo Jaime Cortesão, o mapa de Lopo Homem é exposto em ampliação colorida. Segundo a legenda que o acompanha, os 146 topônimos são demonstrativos da intensa exploração do litoral entre 1500 e 1519, destacando que "o desenho do trecho do litoral, entre a Baía de Guanabara e a Ilha Grande, revela conhecimento difícil de explicar sem a tentativa de colonização anterior". Além disso, o texto que ladeia o painel, dialogando com o visitante, comenta as bandeiras portuguesas dispostas ao norte do delta amazônico e ao sul do estuário platino, a reivindicar soberania sobre territórios situados a oeste de Tordesilhas: "para justificar este ambicioso desígnio, o cartógrafo real distendeu todo

\footnotetext{
${ }^{251}$ CORTESÃo, J. O Brasil na pintura e cartografia manuelinas. Conferência. São Paulo, dez. 1940. BNP/ACPC E25/33. A Carta de Lopo Homem (1519) teve autoria e data identificadas em Paris, em reunião na Biblioteca Nacional francesa com a presença de Cortesão (BNP/ACPC E25/34).

${ }^{252}$ CORTESÃO, J. Cartas do Brasil: História do Cruzeiro do Sul. [Rio de Janeiro], [1946?]. BNP/ACPC $\mathrm{E} 25 / 36$.
} 
o litoral brasileiro enormemente para leste, chegando o desvio a atingir 12 graus, na parte compreendida entre o Cabo de Santo Agostinho e o delta amazônico". A informação é parte do raciocínio que foi amplamente discutido pelo autor, já apresentado neste texto e discutido por Íris Kantor, a respeito dos erros que seriam cometidos propositalmente com fins reivindicatórios.

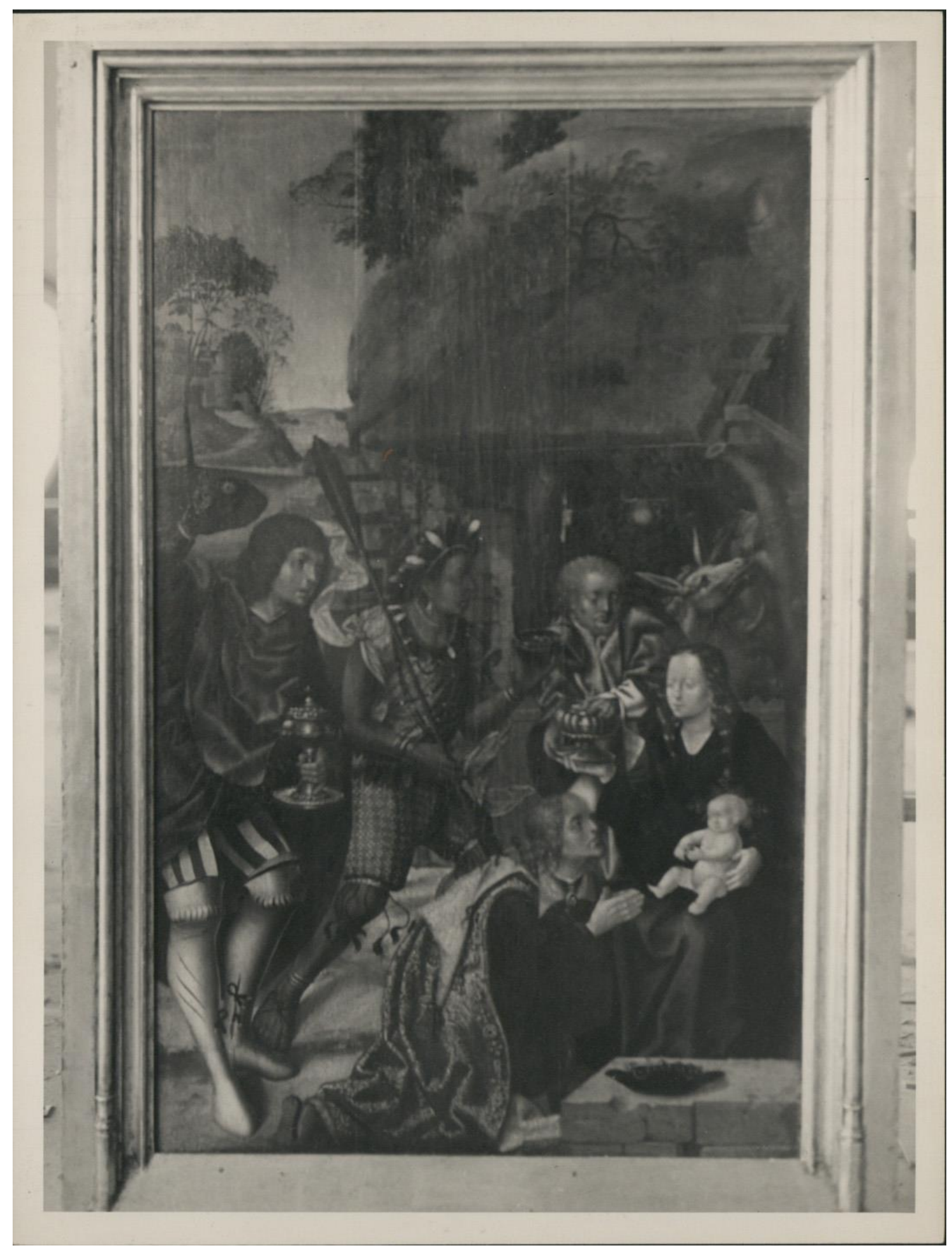

Imagem 9. A Adoração dos Reis Magos. Retábulo da Sé de Viseu. Vasco Fernandes (Grão Vasco), óleo sobre madeira, c. 1506. Museu Grão Vasco de Viseu. São Paulo, s/d. Fotógrafo não identificado. BNP/ACPC E25/1495. 
Ainda do texto que se apresenta como legenda ao mapa ampliado, cujo original, como vimos, não foi cedido pela Biblioteca Nacional da França, faz-se uma leitura do documento, apontando para distintivos do território, caracterizados etnográfica e "economicamente": os índios "com os mesmos costumes" e a extração do pau-brasil são marcas da carta, bem como a fauna. Uma tradução da legenda do mapa original também é disposta, identificando a região como "grande Brasil", local de gente "escura, selvática e ferocíssima", que "come carne humana" e "maneja com perfeição o arco e as setas". Painéis adiante no percurso, estudos de Armando Cortesão sobre a toponímia desta carta e das de Canério (c. 1506) e Gaspar Viegas (c. 1534) são apresentados, marcando mais uma vez o viés do estudo sistemático da cartografia como relevante na produção da escrita histórica e museológica de Cortesão.

O painel de encerramento da primeira seção contou com o apoio do almirante Gago Coutinho, aviador português que fez em 1922 a primeira travessia aérea do Atlântico Sul ligando Lisboa ao Rio de Janeiro. Coutinho realizou estudos sobre as rotas prováveis de Colombo, Cabral e Vasco da Gama, que foram expressos em mapas feitos pelo comandante Campos Costa. Segundo Cortesão, as conclusões do aviador indicam que entre as viagens de Vasco da Gama e Cabral já havia se estabelecido a "melhor rota" para atingir o Brasil, considerando os conhecimentos que eram utilizados pela aviação àquela época. Com a ponte estabelecida, o navegador e o aviador, pioneiros nos caminhos sul-atlânticos, ressaltava-se o conhecimento geográfico como próprio dos portugueses: no passado e no presente, eram os lusos a estabelecer as ligações, antes pelo mar e ora pelo ar, entre a Europa e o Atlântico Sul. Aquele oceano era, portanto, como um espaço desbravado e conhecido pelos portugueses, povo a ele vocacionado, podendo ser entendido como a própria extensão do território da pequena nação ibérica.

Expondo também diversas cartas da mapoteca do Itamaraty, Cortesão apresentou ao longo da seção de abertura as premissas que orientaram os cursos que ofereceu no âmbito do Instituto Rio Branco, essencialmente expressos na sua História do Brasil nos Velhos Mapas (1957) bem como o projeto não concretizado de Atlas Histórico do Brasil. Ideias-chave como "descoberta dos litorais", "fundamentos geográficos do Estado brasileiro", "realização geográfica", "unidade" entre outros caracterizam os seus escritos sobre o processo que nomeou como de formação 
territorial do Brasil. ${ }^{253} \mathrm{Na}$ seção de abertura, o primeiro passo da epopeia da colonização brasileira consiste em conhecer céus e mares, aportar, fincar padrões de descobrimento, descrever e nomear a terra e as gentes, literária e pictoricamente.

\section{Seção II - A cultura do índio e do adventício}

Após descrever o ato de plantar padrões na costa, como o marco encontrado em Cananeia e exposto na primeira seção, e de descrever as gentes, a natureza e o território na literatura, na cartografia e na pintura, dá-se, na segunda seção ${ }^{254}$, "uma forma lógica e viva à Exposição" por meio da narrativa do "encontro do português, ao desembarcar, com os aborígenes". O encontro entre o índio e o adventício é descrito, conforme indica o texto introdutório do catálogo, como a matriz de "muitos aspectos específicos da cultura brasileira e, mais designadamente, da paulista". No mesmo texto, considera-se tal encontro enquanto "reações" da cultura portuguesa às "formas tão diversas da cultura indígena".

Com 20 painéis e oito vitrines, a segunda seção é aberta com um texto indicando ao visitante o processo que será descrito nos próximos passos de seu percurso por dentro da Oca: "Os primeiros colonos, para sobreviver, tiveram que adaptar-se à cultura aborígene, isto é, tupinizaram-se: nos processos de caça e pesca, na alimentação, no vestuário, nos utensílios, na vivenda, nos lazeres". Ao que se qualifica como pertencente à cultura indígena, são dedicados seis painéis e uma vitrine, onde figuram objetos como os que figuram no trecho capturado pela fotografia acima (imagem 9). Agrupam-se, de acordo com o que se descreve no catálogo, imagens e representações dos índios Tupinambá desde as do viajante alemão Hans Staden (1547) aos Tupi contemporâneos em três conjuntos: desenhos de costumes indígenas segundo o livro de Staden; fotografias de Tupi em atividades cotidianas, como o transporte de caça e o descascar da mandioca; desenhos de objetos, como cesta de transporte de carga, arco, flechas, rede, espremedor de

\footnotetext{
${ }^{253}$ Uma primeira observação, colocando lado a lado o programa do Atlas Histórico, a publicação História do Brasil nos Velhos Mapas e os pontos discutidos em seus cursos no Itamaraty, bem como a linha que norteia a execução da Exposição de História de São Paulo permite inferir que se trata, em essência, de um mesmo raciocínio, expresso em linguagens mais ou menos distintas para públicos diversos.

${ }^{254}$ CORTESÃO, J. et al. Seção II - A cultura do índio e do adventício. In: $18 \mathrm{p}$. Op. cit., $[1954 / 1955]$,
} 
mandioca. Conforme o texto da introdução do catálogo, "escolheu-se como modelo para figuras indígenas, e por motivos óbvios, o tupi, como aparece nas gravuras da obra de Hans Staden". Salta aos olhos o que seriam os tais "motivos óbvios" da opção pelos Tupi, que, de acordo com o que se diz na sequência, estão ligados "às origens da Capitania de S. Vicente". Como veremos no próximo capítulo, essa foi uma discussão constante nos círculos de historiadores locais, ávidos pela eleição de um modelo heroico de antepassado nativo, trabalhando intensamente com o binômio Tupi e Tapuia para se referir aos índios. Tais categorias expressavam uma oposição ente dócil e arredio, civilizado e selvagem, respectivamente.

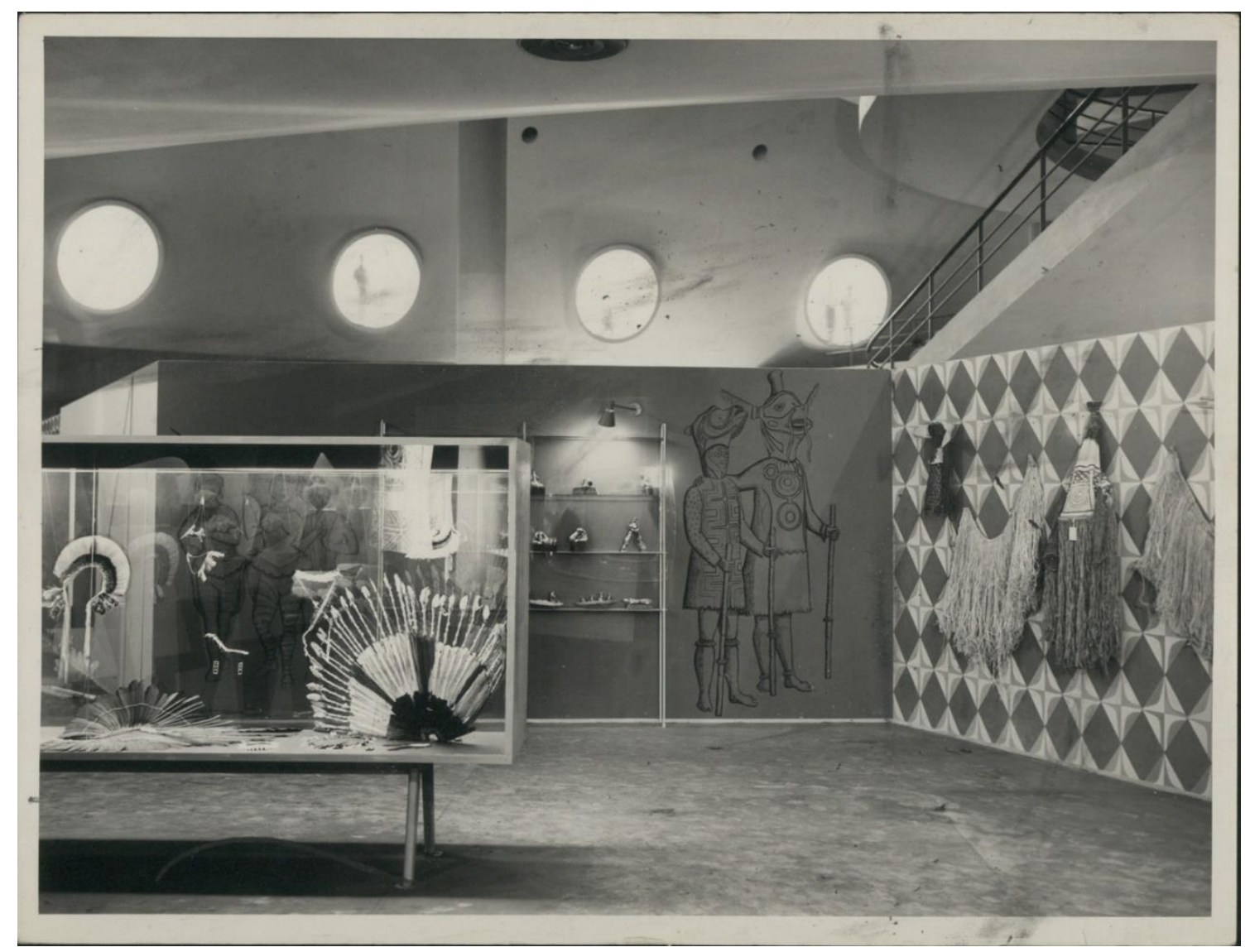

Imagem 10. A cultura do indio, que abre a II seção da Exposição de História. São Paulo, 13 set. 1954. Fotógrafo: Bernardelli. $B N P / A C P C E 25 / 1488$.

Baseando-se essencialmente na cultura material, - e é este o conceito que traz o texto de introdução ao catálogo - nos registros de viajantes e nas fotografias desses mesmos povos à época da exposição, apresenta-se não apenas o passado como também o presente, numa perspectiva construída com "a colaboração preciosa do jovem mestre da etnografia índia, Darcy Ribeiro, Diretor do Museu do Índio do Rio de Janeiro", museu este que emprestou todas as peças expostas no primeiro setor da segunda seção. 
No interior da vitrine que aparece no primeiro plano da fotografia acima (imagem 10), adornos de cabeça, colares de penas, de dentes e de contas, entre outros estão dispostos próximos a objetos cerâmicos e vestimentas, também representadas em desenhos ampliados. Na sequência, a cerâmica se destaca no interior de uma vitrine composta por objetos Carajá como bonecas e esculturas de animais. Junto desse grupo, fotografias de cenas cotidianas Xavante e de outros povos, provavelmente Carajá, são apresentadas. A cerâmica é ainda apresentada por meio de mapas sobre a distribuição dessa técnica pelo território brasileiro, identificando especialmente os grupos Guarani, Tapajó, Marajoara e Caduveu. O tema dentro da seção que leva o nome da "cultura do índio" é encerrado com uma instalação que demonstra um acampamento de praia Carajá, com paravento armado, esteiras, canoa, cuias, cestos, pratos, rede, lança, entre outros objetos.

Sem legendas que oferecessem maiores informações sobre os objetos e cenas apresentados, o assunto é encerrado com um texto que, ao mesmo tempo, introduz as "culturas antigas" que viriam representadas a seguir. Como anunciado pela introdução do catálogo, os elementos que tornaram presentes as culturas indígenas selecionadas para participar da mostra são dotados do sentido oferecido pelas legendas de abertura e ora a de encerramento. Tal sentido é dado pela "reação" dos portugueses ao contato: "E adaptando-se, pôde o português implantar melhor os princípios de uma civilização própria (...)", civilização esta radicada em todas as matrizes vêm a seguir e, especialmente, na "cultura náutica, na organização política, (...), pela amorabilidade franciscana (...)". Para o visitante, o trecho inicial da segunda seção oferecia, sobretudo a partir da interpretação colocada pelas legendas, uma compreensão dos povos indígenas como culturalmente estáveis, apresentando tradições e produções que teriam permanecido. À essas culturas, o adventício se adaptaria e implementaria o seu padrão civilizacional, construído há tempos pelas diversas influências que teria recebido de culturas antigas e medievais. Nesse sentido, narrava-se na exposição uma história em que, a despeito da relevância dada às culturas indígenas - ainda que se desse ênfase às Tupi -, o timoneiro seria o português.

Para caracterizar a cultura portuguesa que aportava e entrava em contato com o índio sul-americano, o caminho partia das culturas antigas, vistas a partir das contribuições deixadas às culturas modernas. Como antigos, gregos, romanos e hebreus são distinguidos. Os painéis a seguir individualizavam as culturas modernas 
e as suas contribuições aos portugueses, em primeiro lugar figurando árabes e normandos. Dos primeiros, destacam-se o comércio internacional, as culturas geográfica, matemática e cosmográfica, a arquitetura e as artes decorativas dos primeiros e as novas vias comerciais, a vida urbana, a burguesia e o espírito laico dos últimos. Ambos ganharam painéis sintéticos com textos, apresentados de forma bastante distinta das culturas de outros povos.

Do medievo, do renascimento e da era moderna, as culturas italiana, francesa, inglesa, holandesa e espanhola, países "em maior ou menor grau ligados à história do Brasil", além de textos que sintetizavam alguns dos aspectos considerados como mais relevantes, objetos e imagens, originais ou reproduzidos, materializavam essas presenças no percurso expositivo. Entre exemplares, emprestados das Bibliotecas Nacional do Rio de Janeiro e Municipal de São Paulo, de obras como A Divina Comédia de Dante Alighieri, a Chanson de Roland, os Colóquios de Erasmo de Roterdã, Don Quijote de Cervantes, entre outros, expunham-se traços das mentalidades, das letras, das artes, das ciências europeias. Este segmento, das culturas antigas às modernas, era composto por oito painéis e três vitrines, além de dois destaques: uma imagem de São Francisco de Assis, de propriedade da ordem franciscana da cidade de São Paulo, acompanhada de uma legenda em que se vincula o Franciscanismo à preparação para os descobrimentos portugueses por meio da santificação da terra ${ }^{255}$; e uma fotocópia do Juizo Final de Michelangelo na Capela Sistina, cuja legenda chama a atenção para a representação de Portugal como "um jovem atleta, arrancando às penas do inferno um índio e um negro presos por um rosário". Em suma, expressavam-se assim traços considerados marcantes da formação cultural portuguesa e que teriam orientado as suas ações, inclusive aquelas em relação às terras e povos extraeuropeus.

O terceiro segmento da segunda seção tratou especificamente da cultura portuguesa, que ocupou seis painéis e três vitrines. Inicia-se o assunto pelo comércio e agricultura no período medieval, destacando o vinho, o peixe seco, as frutas, o mel e o sal e também apresentando mapas com rotas comerciais portuguesas na Europa medieval e na costa africana no século XV.

\footnotetext{
${ }^{255}$ A reflexão de Cortesão sobre o Franciscanismo e a formação da cultura portuguesa, especialmente no que se refere às relações com outras terras e povos, está contida em sua obra $O$ Humanismo Universalista dos Portugueses, que será abordada no próximo capítulo, quando tratarei da forma como o autor pensou as relações entre os portugueses e os povos das regiões em que aportou.
} 
Os "cultos populares" dão seguimento às definições expostas da cultura portuguesa, enfatizando então os cultos do Espírito Santo, de São Vicente e de Santo Antônio. Cada um desses cultos ganha destaque especial: o do Espírito Santo é apresentado em uma vitrine, com objetos, como coroas e bandeiras, relacionados à festividade que celebrava a instauração de um Império divino, com a coroação de um menino e um farto banquete. De acordo com a legenda que acompanha as peças de museus portugueses e brasileiros, a festa se difundiu largamente, dando "ao cristianismo português o caráter de uma religião de descobridores, tendo por missão propagar a Fé e o Império". Agostinho da Silva se dedicou largamente sobre o assunto. ${ }^{256}$ São Vicente, o patrono das descobertas e da primeira vila fundada no litoral brasileiro, figurava em uma pintura setecentista de Cristóvão de Figueiredo, pertencente à Câmara Municipal do Porto. Por fim, Santo Antônio, o orador franciscano nascido em Lisboa e que entrou para os cânones como de Pádua, de quem Cortesão se ocupou na introdução do volume inicial de Clássicos $e$ Contemporâneos e n'O Humanismo Universalista dos Portugueses, foi representado na exposição por meio de uma imagem barroca do santo emprestada pelo Museu Nacional de Arte Antiga, de Lisboa.

Aprofundando o tema da cultura portuguesa, as vitrines e painéis expostos na sequência traziam objetos como bandeiras como as das Irmandades de Misericórdia, que fundaram hospitais em Portugal e no Brasil, exemplares d'Os Lusíadas - um da primeira edição de 1572 e outro de 1670, que acompanhou Gago Coutinho e Sacadura Cabral na primeira travessia aérea do Atlântico Sul - ambos do Gabinete Português de Leitura, entre outros documentos. As peças então expostas descreviam as contribuições portuguesas à Europa medieval, renascentista e moderna, especialmente na economia, nas ciências, nas técnicas, nas artes, na religião. Além de Camões, Gil Vicente e a sua caracterização da sociedade portuguesa se fazem representados junto de Fernão Mendes Pinto e Jorge Ferreira de Vasconcelos, compondo o que se denomina como "literatura típica de navegadores oceânicos".

Especificada, a cultura náutica é representada por meio de objetos como astrolábios, balhestilhas, roteiros e livros, bem como pela miniatura de uma caravela, "criação náutica portuguesa e instrumento que serviu ao descobrimento dos litorais",

\footnotetext{
${ }^{256}$ A esse respeito, ver PINHO, A. A diáspora da inteligência lusa na hermenêutica histórica de Agostinho da Silva: uma teoria antielitista da história de Portugal? In: Convergência Lusíada, Rio de Janeiro, n. 23, 2007.
} 
conforme a legenda que a acompanha. A imagem abaixo (imagem 11) apresenta como estava disposto tal trecho da mostra:

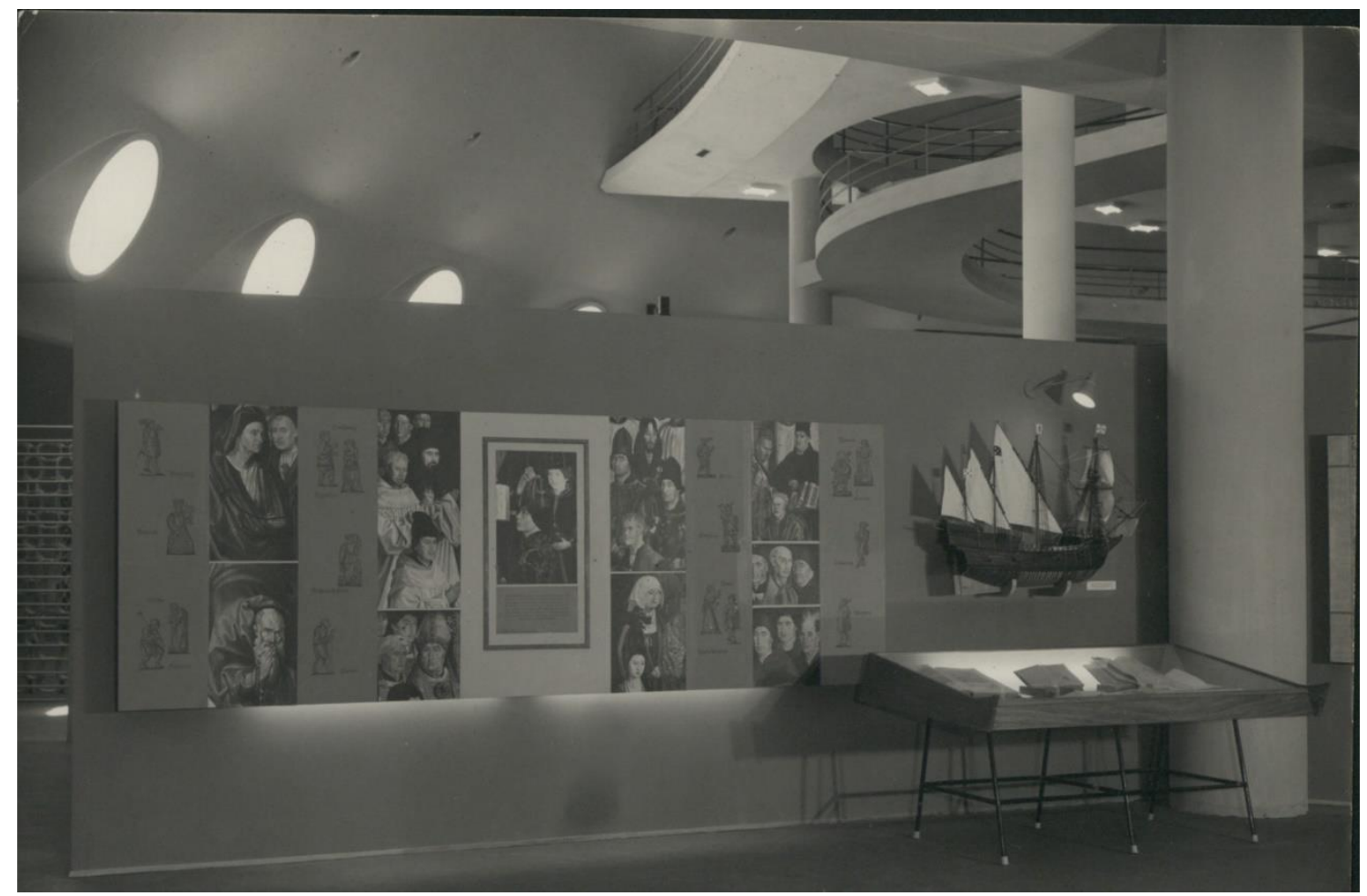

Imagem 11. Aspectos da cultura portuguesa. São Paulo, s/d. Fotógrafo não identificado. BNP/ACPC E25/1503.

Abaixo da miniatura de caravela, provavelmente encontra-se a vitrine com objetos relativos à cultura náutica. Ao lado, o penúltimo painel relativo a Portugal, trazia reproduções ampliadas de gravuras antigas representando funções reais no começo do século XVI, tais como a regulação comercial, a administração jurídica, o trato direto com os mercadores do "tráfico oriental", a fidelidade às Ordenações do Reino, a presidência de julgamentos junto a letrados, doutores e escribas. Encerrando os painéis e vitrines do assunto, um políptico de Manuel Lapa, de traços modernos, representava, em cinco quadros, os trabalhos agrícolas e pastoris dos portugueses no século de Quinhentos, como se vê na imagem a seguir (imagem 12): 


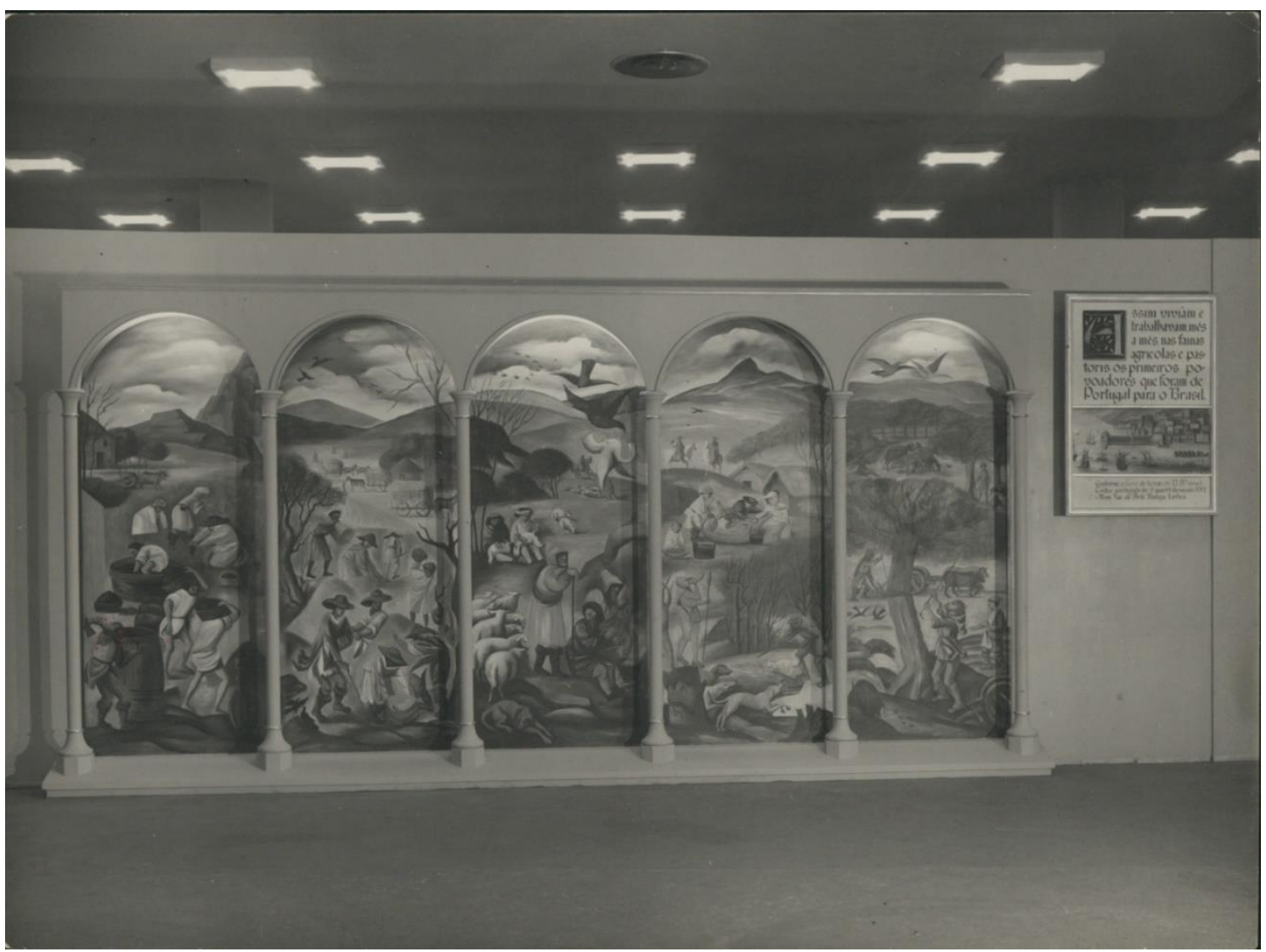

Imagem 12. O povo português do século de Quinhentos nas fainas pastoris e agrícolas. São Paulo, s/d. Fotógrafo não identificado. BNP/ACPC E25/1500.

A legenda, simulando um manuscrito iluminado, inscreve: "Assim viviam e trabalhavam mês a mês nas fainas agrícolas e pastoris os primeiros povoadores que foram de Portugal para o Brasil". Nesses termos, a descrição e a imagem pretendem compor, somados aos elementos antes trazidos, uma caracterização idealizada do português que aportou no Brasil, destacando as diversas qualidades construídas a partir de influências diversas de outros povos. Três pinturas da escola portuguesa figuram como destaques, duas quinhentistas e uma do século XIX: uma inspirada na obra de Gil Vicente, outra de Vasco Fernandes sobre A Criação dos Animais e um retrato de São Pedro Gonçalves Telmo, patrono dos marinheiros contra as tormentas, de autor desconhecido. Destaca-se da primeira obra a presença de um índio sob forma demoníaca e da segunda um papagaio representando as aves. Considerando o texto da introdução do catálogo, no trecho referente à segunda seção, demonstra-se a escolha no tratamento da questão da cultura portuguesa. Conforme consta, procurou-se singularizar os mais "típicos" aspectos culturais lusitanos, com o objetivo principal de "restituir a civilização brasileira, quer à sua 
maior profundidade histórica, quer às suas relações de origem com a história de Portugal".

Finalizando a segunda seção e enquadrado igualmente na categoria "adventício", um segmento de um único painel é "representativo da Arte Negra da África Portuguesa: Guiné, Angola e Moçambique". Além de "desenhos indígenas d'África", do Museu Agrícola do Ultramar, objetos sem cedentes identificados são descritos somente em relação a sua origem. Eram três máscaras e dois "flamingos" de Angola; duas ânforas de São Tomé e Príncipe; um vaso policromado e um "hipopótamo" da Guiné; um "feitiço" do Congo; um banco de soba de Luanda e um banco de Moçambique. A única legenda a caracterizar o segmento final é a mesma que encerra a seção: "Da presença simultânea e das influências recíprocas de três culturas, a do índio, a do português e a do negro, numa terra nova, vai surgir uma nova grei" - a segunda seção, portanto, dá visualidade à longa discussão sobre as "três raças", já discutida neste trabalho e a qual ainda se somarão outros elementos no próximo capítulo. Não só pelo espaço dedicado a cada um destes três "elementos fundadores" da identidade brasileira como pela forma como foram apresentados e descritos, pode-se perceber a valoração dada a cada um na composição da nacionalidade, sustentando a ideia de uma hegemonia europeia/portuguesa na constituição da gente, da cultura, da técnica, das artes e da ciência brasileiras.

\section{Seção III - A fundação de São Paulo e o pré-bandeirismo}

Segundo o texto introdutório do catálogo, as relações com a história portuguesa descritas na seção anterior se sobressaem na terceira, dedicada à fundação de São Paulo e centrada na sua formação urbana e no chamado pré-bandeirismo. Ainda de acordo com o texto, discute-se a tese sustentada de que "a fundação de São Paulo foi um ato fluido no tempo e múltiplo na ação, com profundas raízes préhistóricas, mas cuja realização, sob a espécie histórica, decorreu entre os anos de 1532 e 1560". A data de 25 de janeiro de 1554 "representa ou deve representar uma simplificação simbólica, útil para efeitos comemorativos, mas que envolve o risco de nos fazer esquecer o significado complexo da fundação". Esse significado complexo está compreendido nas ações de Martim Afonso de Sousa, o padre Manuel da 
Nóbrega e as vilas e o colégio fundados no "campo" e que acabaram por se consolidar em torno do colégio jesuítico instalado sob a proteção do apóstolo Paulo.

Nesse sentido, a seção destaca os "primitivos povoadores de S. Vicente": João Ramalho, Gonçalo da Costa e Antonio Rodrigues. João Ramalho, especialmente, foi quem apontou "aos demais portugueses o caminho do planalto e as vantagens de estabelecer ali um povoado regular, com base na iniciativa do Estado e nas Ordenações do Reino". Também nesse trecho da exposição se deu grande importância "ao passo do 'Diário de Pero Lopes' sobre a fundação de S. Vicente e Piratininga, quer pela sua importância como documento basilar sobre essa dupla fundação, como pela elevação dos termos com que o irmão de Martim Afonso se lhe refere". Outro documento destacado da seção é uma Carta da Imperatriz (Isabel, irmã de D. João III), de 17 de fevereiro de 1531, segundo a qual um dos pioneiros de São Vicente (Gonçalo da Costa), depois de falar ao rei português, informou à imperatriz que "Martim Afonso e os seus companheiros de expedição levavam, como um dos objetivos fundamentais, fortificar S. Vicente e 'desde esse porto que está na sua demarcação, pensavam entrar por terra ao rio da Prata"” (grifos do autor). Tal informação, um ano e meio antes da fundação de Piratininga é ilustrada pelo mapa de Gaspar Viegas (1534), segundo o qual

os afluentes terminais do Paraná, um dos quais na situação do Tietê, se aproximam muito, pelas suas fontes, do litoral; e sabido que os portugueses se propunham como objetivo máximo alcançar o ouro do Paraguai, permitiram-nos atribuir, em legenda, ao Rei de Portugal e a Martim Afonso, inspirados por João Ramalho, a glória de ter fundado a vila de Piratininga, na consciência das suas vantagens de posição, como base da formação territorial do Brasil. ${ }^{257}$

Ainda sobre o assunto, acrescenta-se que se há atribuição de importância à ação jesuítica no planalto desde o começo da segunda metade do XVI, não se pode deixar de lado as iniciativas "fecundíssimas em consequências" dos moradores civis na criação de uma economia peculiar ao planalto, centrada na criação de gado e de uma indústria primitiva de ferro. Se a primeira era fundamental para a manutenção da vila, a segunda serviu "de base às trocas vitais pelos produtos indígenas, que atou as sólidas relações de convivência e comércio com as tribos do interior e foi o

257 CORTESÃO, J. et al. Introdução. In: Op. cit. [1954/1955]. Vale ressaltar que os três personagens: Martim Afonso, D. João III e João Ramalho figuram em destaque no saguão de entrada do Museu Paulista, conforme as escolhas museológicas de seu ex-diretor Afonso Taunay, citado no catálogo da Exposição de História como autor de um dos textos de 1953 sobre este assunto destacado. 
verdadeiro prólogo à penetração nos sertões". As Atas da Câmara de São Paulo são apresentadas então na exposição como importantes documentos a respeito do surgimento dessa criação de gado, difundida então nos "campos" do planalto. Da criação da Câmara, em 1560, diz-se que a sua instalação, ao lado do Colégio, faz dela "baluarte do espírito de liberdade e autonomia e defesa do sentido de vida independente e expansionista, que havia de caracterizar o bandeirismo".

$\mathrm{O}$ texto introdutório indica sobre a preparação dos documentos para a exposição ao mencionar que das dezenas de mapas resultados das primeiras entradas nos sertões, quase todos inéditos, dois tinham sido selecionados: o de Bartolomeu Velho (1562) e o de Luiz Teixeira (c. 1584). No primeiro, o Brasil é figurado como uma ilha, limitada pelos rios Paraguai e Tocantins, unidos pela lagoa Eupana. Apresentam-se também os rios Paraná, Piqueri, o Salto do Guairá e os rios que levam a Assunção "resto evidente das viagens comerciais dos vicentistas àquela cidade". $\mathrm{O}$ segundo, de Luís Teixeira, registra a "região explorada por Jerônimo Leitão", apresentando "pela primeira vez segundo cremos", o vale do Paraná e os seus afluentes da margem esquerda: "Imbi (Anhembi); Parapenem (Paranapanema); Ubay (Ivaí); Pequiri e o Guaiçu (Iguaçu)". De acordo com o texto, o documento que provavelmente apresenta "um primeiro traçado hidrográfico, tão importante para a história da formação do Brasil", pode também ser o primeiro a mencionar e a situar, "com relativa exatidão, o Anhembi ou Tietê".

Continuando sobre os mapas da seção, as únicas peças destacadas no texto introdutório, Cortesão lembra o mito geográfico que também deu à lagoa do interior do continente o nome de Dourado ou do Ouro, chamando a atenção "para a fotocópia dum alvará de nomeação, por el Rei D. Sebastião, de Domingos Garrucho para 'mestre do Campo Geral da jornada de descobrimento da lagoa que chamam do Ouro"'. O documento de 1576 pode indicar "o primeiro projeto de descobrimento da Lagoa do Ouro, que foi, alguns anos volvidos, o alvo, conforme o testemunho de frei Vicente do Salvador, da entrada de Gabriel Soares de Sousa". No texto, Cortesão lembra que Garrucho era morador da capitania vicentina.

O processo descrito, discutido nos seus pormenores em $A$ fundação de São Paulo: capital geográfica do Brasil (1955), foi então apresentado em 14 painéis e dez 
vitrines na terceira seção da exposição. ${ }^{258}$ A seção foi aberta com um mapa da Vila de São Vicente, reproduzido do original de Alonso da Santa Cruz, cosmógrafo espanhol que esteve na região em 1530. A legenda identifica o autor da carta, registrando também o que disse sobre a região: "um povoado de dez ou doze casas, uma feita de pedra com seu telhado e uma torre para defesa contra os índios e, tempo de necessidade". A legenda comunica também que no local viviam náufragos, entre eles Gonçalo da Costa e que "nessa povoação e nesses povoadores afunda suas raízes a futura vila de São Paulo de Piratininga", identificando assim uma "pré-fundação" de São Paulo, um marco inicial do processo que se estendeu pelas décadas seguintes e que não se encerra na data de 25 de janeiro de 1554 .

Os primeiros povoadores de São Vicente são representados por Manuel Lapa e na sequência por painéis ou destaques especiais para cada um deles: João Ramalho, Gonçalo da Costa e Antônio Rodrigues. Na legenda, um trecho selecionado do Diário de Pero Lopes de Sousa (1532) deu sentido às três figuras, narrando as determinações do capitão Martim Afonso e de seu grupo: "A todos nos pareceu tão bem esta terra que o capitão determinou de a povoar e deu a todos os homens terras para fazerem fazendas", fazendo uma vila na ilha de São Vicente e outra "nove léguas dentro, pelo sertão, à borda de um rio que se chamava Piratininga", repartindo as pessoas nas duas povoações e dotando-as das estruturas pertinentes de então. Um retrato de Martim Afonso também por Manuel Lapa, é apresentado em destaque na sequência, outorgando-lhe, junto ao rei de Portugal, "a glória (...) de ter fundado a vila de Piratininga, na consciência das suas vantagens de posição como base da formação territorial do Brasil", glória esta baseada na Carta da Imperatriz. Comunicava-se assim o sentido da fundação de São Paulo em relação à história da formação territorial do Brasil, fruto de determinações da Coroa.

Nas vitrines a seguir, documentos expostos, emprestados do Arquivo Nacional da Torre do Tombo, apresentavam registros relacionados às ações de Martim Afonso, Pero Lopes e João Ramalho concernentes ao processo de povoação, deslocamentos, sesmarias. Duas pedras quinhentistas também complementam o quadro dos anos iniciais da colonização: do Museu Paulista, ambas fazem parte do acervo permanentemente exposto pelo museu na atualidade.

\footnotetext{
${ }^{258}$ As informações a seguir constam do catálogo da exposição: CORTESÃO, J. et al. Seção III - A fundação de São Paulo e o pré-bandeirismo. In: Op. cit., [1954/1955], 23 p.
} 
Do original levantado na Sociedade de Geografia de Lisboa, uma versão facsimilar do mapa de Gaspar Viegas (1534), comentado anteriormente, foi exposta no painel que traz uma sequência de documentos cartográficos a fundamentar a tese da fundação de São Paulo como a "capital geográfica" do país. Registrado como representativo dos "novos conhecimentos geográficos adquiridos pela expedição de Martim Afonso", o mapa de Viegas foi sobreposto, em seguida, a um mapa contemporâneo, conduzindo à leitura de que "D. João III pretendia abranger na soberania portuguesa todo o vale do Prata". Além disso, "pelo traçado do Paraná e de seus afluentes terminais", o referido mapa permitia a conclusão, segundo Cortesão, que a fundação de Piratininga perto do Tietê por Martim Afonso demonstrava a "consciência do grande valor dessa posição geográfica que permitiria a expansão do Brasil na direção do Prata". Ainda no painel, parte de um planisfério de André Homem (1559), onde o Brasil ainda figura como ilha, compõe a reflexão que ainda é complementada pela Carta de Bartolomeu Velho (1562), que também apresenta o Brasil como ilha, dessa vez limitada pelos Paraná e Tocantins, unidos pela lagoa Eupana. Ary Duarte, cartógrafo que trabalhou junto de Cortesão no Itamaraty e na edição de $A$ Fundação de São Paulo e de outras obras, elaborou um mapa demonstrando as "grandes penetrações portuguesas anteriores às bandeiras", como a "proto-bandeira" de Aleixo Garcia (1522) e a de Antônio Rodrigues (15361542).

Uma vitrine é dedicada a documentos relativos à Santos, entre eles a fotocópia de uma carta do monarca português endereçada a João Luís Corrêa. Nela, D. João III afirmava que Assunção estava dentro das possessões portuguesas e demonstrava preocupação com a expansão castelhana. $\mathrm{Na}$ vitrine seguinte, outros documentos iam se somando à narrativa do conhecimento sobre a terra e das intenções da realeza portuguesa com as expedições. Entre eles, a fotocópia do alvará com o qual D. Sebastião nomeia o vicentino Domingos Garrucho como "mestre de campo geral da jornada de descobrimento da Lagoa que chama do Ouro".

Mais dois painéis com mapas diversos, incluindo holandeses e portugueses, do século XVI, buscam dar conta das representações da América do Sul, das costas africana e brasileira, da região andina, bem como os de Luiz Teixeira já mencionados aqui. Um de Teixeira, de cerca de 1587, foi ampliado e sobreposto sobre um mapa brasileiro contemporâneo - técnica utilizada na exposição em outro momento, como vimos - e que desta vez assim se fez, pelo Comandante Campos Costa, "para 
evidenciar as quase concordâncias de latitude e as grandes divergências de longitude". Outros três mapas apresentados nessa parte da seção também foram produzidos especialmente para a exibição, executados por uma equipe coordenada pelo engenheiro César Bierrenbach de Lima, com dados do arquivo Aguirra: tais mapas deram início a uma série distribuída pelas seções relativa à "marcha da ocupação e desbravamento do território paulista e ao crescimento da área urbana de São Paulo". Os três representavam: a) os pequenos povoados que existiam em 1554; b) São Paulo de Piratininga em 1560; c) sesmarias pedidas ao redor de São Paulo, século XVI.

Três desenhos do artista Fernando Lemos alusivos às fundações de Santo André, Bertioga e Itanhaém apresentam num painel os "pródromos da fundação de São Paulo", ladeados por trechos de uma carta de Tomé de Sousa ao rei de Portugal, datada de junho de 1553, em que se mencionavam os muitos "filhos e netos" de João Ramalho, o natural do termo de Coimbra e que tinha sido feito capitão da vila de Santo André. Outro trecho da carta de Tomé de Sousa foi evocado junto ao painel posterior, para o qual os "artistas da exposição"259 produziram um desenho alusivo ao conhecimento dos caminhos fluviais entre o Planalto de Piratininga e Assunção. $\mathrm{Na}$ correspondência ao rei, Tomé de Sousa identificava a cidade como próxima de Assunção, a uma distância de cerca de cem léguas.

A cidade que foi uma das primeiras fundações espanholas no interior sulamericano também aparece quando se fala do padre Leonardo Nunes, o "primeiro apóstolo" da capitania vicentina que reunia os "brancos esparsos pelo sertão" junto à ermida dedicada a Santo André. O presbítero "tencionava ir a Assunção, utilizando os afluentes do Paraná e do Paraguai", mencionando a Manuel da Nóbrega o seu plano e o tempo que levaria no deslocamento. A partir do que se comunica até então na terceira seção, nota-se o esforço em demonstrar a ligação entre São Paulo e

\footnotetext{
${ }^{259}$ Segundo a ficha técnica da exposição que consta do catálogo, o grupo de artistas e decoradores era composto por: Manuel Lapa (decorador-chefe), Artur Jorge, Fernando Lemos, Arnaldo Pedroso d'Horta, Clóvis Graciano, Emiliano Di Cavalcanti, Estrela de Faria, João Maria dos Santos, Irene de Almeida e Vasconcelos, Miguel Carnicelli Sobrinho, Nelson Nóbrega, Pedro Birkenstein, Tarsila do Amaral, Wladimir Douchkine, Akio Shirakawa, Francisco Cuoco, Francisco Ismael Toledo Falcão, Fukugava Akira e Gontran Guanaes Neto. Havia na equipe diversos nomes conhecidos do movimento modernista, sugerindo mais relações de Cortesão com o grupo e que iam além de Murilo Mendes, casado com a sua filha Maria da Saudade Cortesão, e de alguns de seus correspondentes, de acordo com o que se encontra no espólio, como Mário de Andrade, Cecília Meirelles, Cassiano Ricardo, Carlos Drummond de Andrade, alguns deles inclusive servidores públicos dos tempos de Capanema.
} 
Assunção, cidade em terra reivindicada pela monarquia portuguesa e presente nos planos e ações de moradores vicentinos.

Entre esse ponto da narrativa exposta e os painéis dedicados à data central das comemorações daquele 1954, o destaque foi dos jesuítas, ordem religiosa intimamente ligada à história da fundação piratiningana e vivamente difundida na iconografia comemorativa ao lado dos bandeirantes e dos índios. Em uma vitrine, documentos originais expostos da Biblioteca Pública e Arquivo Distrital de Évora, bem como textos reeditados no ensejo das festas centenárias. O Diálogo da Conversão do Gentio (c. 1557), escrito por Manuel da Nóbrega, era um dos documentos expostos. Seria essa a primeira obra escrita no Brasil sem ser do gênero epistolar, segundo Serafim Neto. Das diversas edições lançadas, destaca-se a última, publicada em Lisboa em 1954 "sob os auspícios da Comissão Portuguesa do IV Centenário de São Paulo", pelo padre jesuíta Serafim Leite. Junto desses documentos, apresentava-se a medalha cunhada pelo governo português em homenagem à fundação de São Paulo.

A fundação de São Paulo - o evento de 25 de janeiro de 1554 - foi concentrado na figura do padre Manuel da Nóbrega (1517-1570), a cuja ação aludia a ilustração feita pelos artistas da exposição. Reforçando a sua ação, a legenda que acompanhava a ilustração chama Nóbrega de "grande missionário e estadista" perante quem o Brasil se inclinava. Ao lado de outros jesuítas, o padre teria lançado os novos fundamentos da povoação do planalto e the dado "espírito de continuidade”. Um mural de Manuel Lapa e Fernando Lemos (imagem 13) representava então a "missa-fundadora", celebrada em 25 de janeiro de 1554. Em letras gravadas sobre pedra antiga, como nos objetos quinhentistas presentes na exposição, a legenda solene posta aos pés do painel modernista em que figuravam índios, padres e colonos registrava: "25 - janeiro - 1554. O Pe. Manuel de Paiva, assistido por outros padres e irmãos leigos jesuítas, reza a missa da conversão do apóstolo que deu seu nome à cidade de S. Paulo".

A missa de fundação era representada de acordo com a estética em voga e não nos moldes acadêmicos da virada do século. O público visitante visualizaria então o simbólico "ato fundador" da cidade de São Paulo de acordo com a estética que dava novas feições ao parque onde se comemorava a grande festa, à cidade e à sua narrativa histórica. Quatrocentos anos depois, fundava-se a cidade "moderna". 


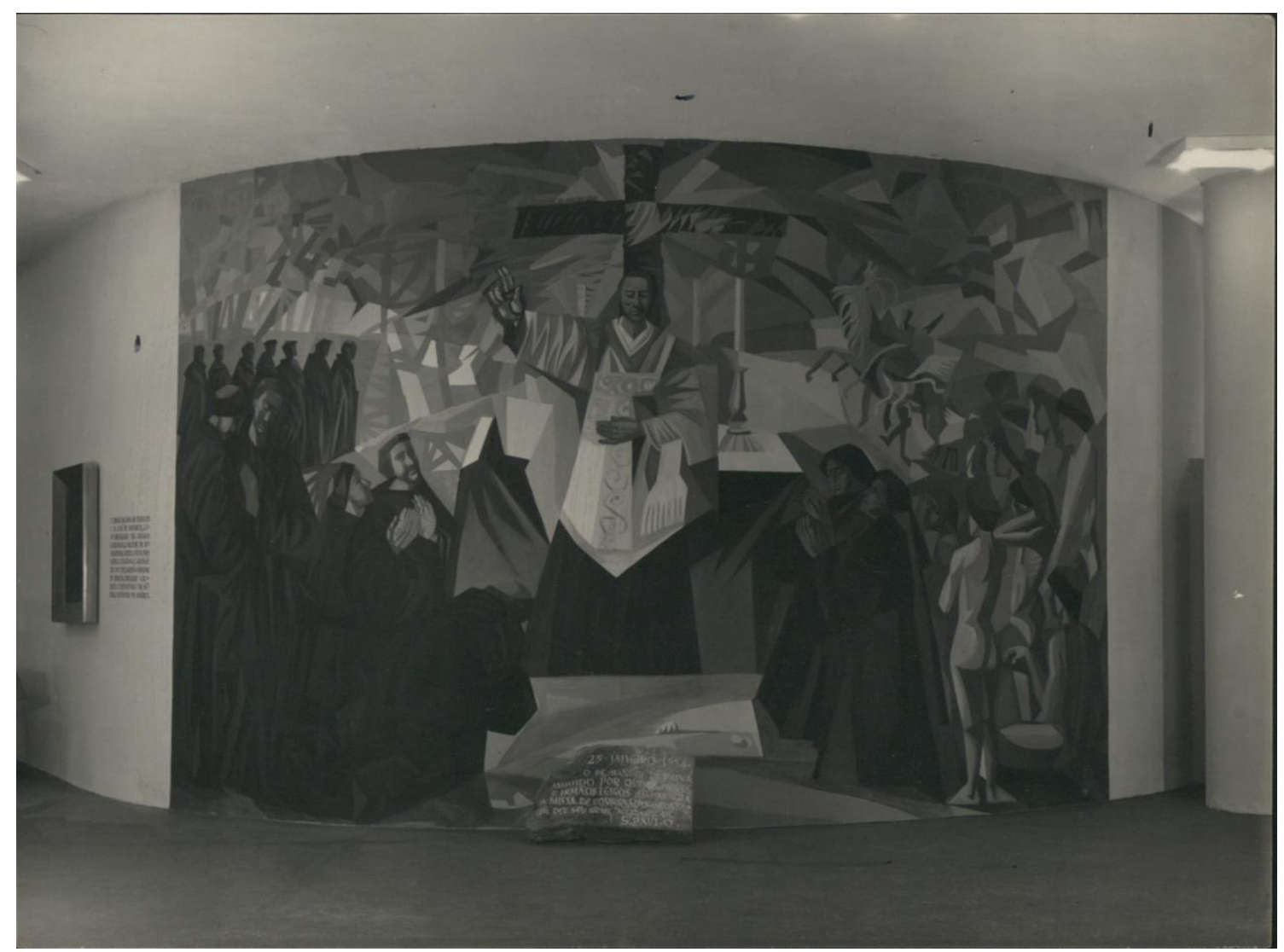

Imagem 13. Missa de 25 de janeiro (Conversão de São Paulo) de 1554. Painel de Manuel Lapa. São Paulo, s/d. Fotógrafo não identificado. BNP/ACPC E25/1513.

Dada a ênfase à Nóbrega, era a vez de apresentar aquele que se fixou no senso comum como fundador da capital paulista, homenageado com uma estátua próxima ao "marco zero" da cidade, na Praça da Sé: o espanhol das Ilhas Canárias José de Anchieta (1534-1570). O retrato apresentado em destaque era considerado o mais antigo do jesuíta segundo Rodrigo de Melo Franco de Andrade. Na pintura pertencente ao Convento Jesuítico de Anchieta, Espírito Santo, há a inscrição Ven. P. Joseph Anchieta - Soc. Jesu Brasiliae Thamaturgus. Na legenda, tão elogiosa quanto a que apresentava Nóbrega, Anchieta é um "luso-brasileiro, de origem espanhola, mestre de humanidades, poeta, autor dramático, etnólogo, gramático do tupi, refém sublime de Iperoig, primeiro cronista e taumaturgo de São Paulo, Apóstolo da América". Para além da "tripla" nacionalidade do espanhol tornado luso-brasileiro, diante de quem igualmente o Brasil se inclinava, a série de epítetos justificaria as homenagens ao padre que era tido como o fundador da cidade, ainda que figurasse na exposição de outra forma. Oportunamente, voltarei à questão da recepção que a mostra teve, especialmente entre os que criticaram as escolhas e critérios de Cortesão. 
Ainda relativos a Anchieta e aos jesuítas, foram apresentados documentos, sobretudo epístolas, bem como um exemplar original, de 1595, da Arte Gramática da Lingua mais usada na Costa do Brasil, pertencente à Biblioteca Nacional do Rio de Janeiro. Paulo Duarte, o criador da revista Anhembi, cedeu para a exposição um exemplar de 1738 de uma biografia de Anchieta, chamado "Apóstolo do Brasil", relacionado ao seu processo de beatificação.

Sobre os habitantes do Campo de Piratininga, um painel apresentou um panorama da economia do planalto, mencionando o gado, as plantações e os hábitos alimentares. Nesse assunto, também se abordou sobre as trocas entre colonos e índios, intercambiando com os nativos especialmente objetos de ferro. Não se diz, porém, nesse painel em que também figuravam algumas das técnicas introduzidas pelos portugueses, como o monjolo, o pilão e o engenho d'água, o que ofereciam os índios.

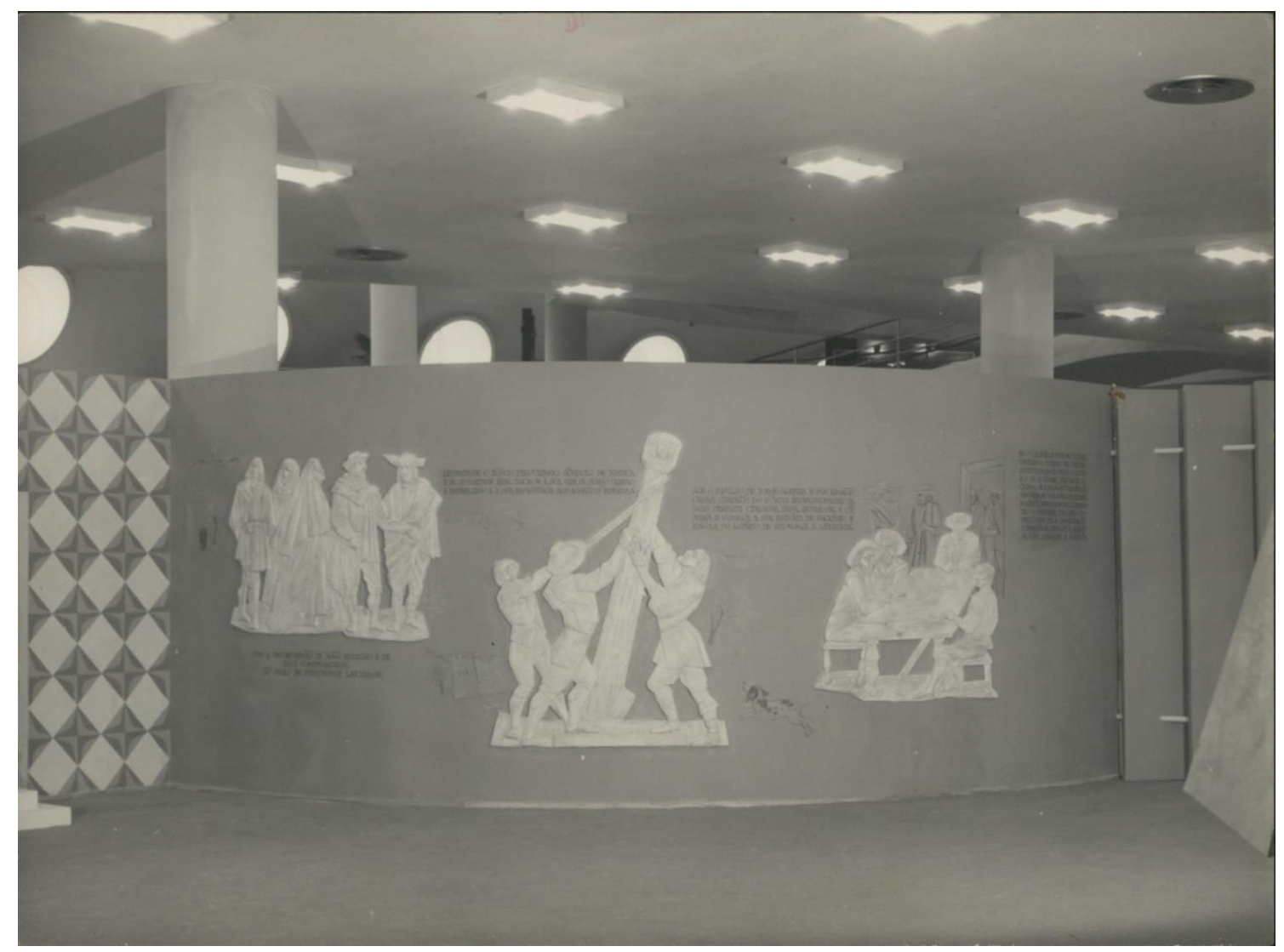

Imagem 14. Baixos-relevos da escultora Irene de Vasconcelos no painel "A criação da Vila". São Paulo, s/d. Fotógrafo não identificado. BNP/ACPC E25/1512.

O último painel da seção, denominado "A criação da Vila" (imagem 14), era composto por três baixos-relevos feitos pela escultora Irene de Vasconcelos. No primeiro, vê-se uma representação da transferência dos moradores de Santo André 
da Borda do Campo para São Paulo de Piratininga; no que se encontra no centro, a representação é da ereção do pelourinho da vila de São Paulo; no último, estava figurada a primeira sessão da Câmara de São Paulo, realizada em 1560, marco final do processo mencionado por Cortesão da fundação de São Paulo. Nos textos que acompanham as representações escultóricas, todo esse processo é descrito: a ordenação para o povoamento expedida pelo rei português a Martim Afonso simbolizava "na fundação de São Paulo a grande capacidade dos portugueses para descortinar as vantagens da posição dos lugares eleitos do planeta"; Manuel da Nóbrega dá seguimento e estabiliza a primeira fundação; Mem de Sá, impelido por Nóbrega, transfere o povoado para Piratininga e lhe concede foros de vila. A base de todo o movimento se funda sobre a geografia, dando sentido àquela fundação que expressava a capacidade portuguesa de apreender o mundo e os seus "lugares eleitos". A liderança de Martim Afonso se fixava no sintético painel final, como o decurso da seção já anunciava.

A incorporação de João Ramalho e dos seus laiciza a vila fundada pelo padre Nóbrega. O pelourinho é o marco fundador do início do burgo, símbolo da justiça e do poder real - próximo ao painel, as pedras do pelourinho de São Vicente, pertencentes ao Museu Paulista, eram exibidas - e por fim, os "representantes da mais perfeita cidadania lusa", cidadãos do Porto (a cidade admirada por Cortesão), reúnem-se e formando a Câmara corporificam o "espírito de autonomia e liberdade". Na casa "baluarte do civismo", a nova entidade política afirmava a bandeira - "tupi pelo instinto, lusa pela organização e finalidade" - que daria "a paixão da vida perigosa e heroica". Próximo às pedras do pelourinho vicentino, o painel sintetizava o espírito presente no processo iniciado por Martim Afonso e concluído com a instalação da Câmara, monumentalizando ali, por meio da linguagem escultórica, aqueles que são eleitos como eventos-chave da formação da municipalidade que daquele momento em diante se lançaria para o sertão. Luso-tupi, a vila apaixonada pela "vida perigosa e heroica" operaria a partir de sua casa cívica a simbiose entre a "organização dos primeiros e o "instinto" dos segundos.

Indicando os caminhos que a exposição seguiria a partir de então, três vitrines encerravam documentações das câmaras de Santo André da Borda do Campo e de São Paulo, bem como mapas, atlas e fragmentos de cartas das décadas do século XVI posteriores à sessão de abertura da Câmara de São Paulo. Além de planos das vilas do Rio de Janeiro, da Bahia de Todos os Santos e de Recife, figuravam naquela 
vitrine reproduções de planisférios e mapas de Luiz Teixeira, Domingos Teixeira, João Teixeira, Vaz Dourado, Pero de Lemos. Ary Duarte compôs para a exposição um mapa da América do Sul conforme Mercator (1569) e um estudo da carta de demarcação portuguesa e espanhola segundo Luiz Teixeira e Lopes de Velasco. Dessa forma, a fundação de São Paulo abria o caminho da "revelação" dos "segredos geográficos" da entidade territorial brasileira, ponto de vista narrado pelas seções seguintes.

\section{Seção IV-Bandeiras e bandeirantes}

A quarta seção, dedicada às bandeiras e aos bandeirantes, foi onde, de acordo com o texto introdutório do catálogo, se procurou "desenvolver e exprimir por forma viva as origens, as causas e as primeiras consequências do bandeirismo, o fato verdadeiramente original, específico e definidor da história de São Paulo". Seguindo a tendência de décadas anteriores sobre o assunto, especialmente entre historiadores paulistas - e mesmo da produção dos símbolos da identidade local - bandeiras e bandeirantes expressavam a "grande contribuição [paulista] para a formação geográfica, social e política do Brasil". A seção parte da referência à criação de uma "economia de forma expansionista", que em uma "posição geográfica eminentemente propícia à expansão" levou por sua vez o paulista a lançar-se aos sertões. Esse capítulo da exposição é indicado pelos parágrafos apresentados como "essenciais":

I - A origem e formação das bandeiras, como fusão de duas culturas, a portuguesa e a aborígene;

II - O problema das fronteiras do Brasil, a resolver pelos bandeirantes paulistas: a realidade e o mito;

III - Os objetivos econômicos e políticos das bandeiras;

IV - A defesa dos bandeirantes contra a lenda negra criada pelos jesuítas espanhóis;

$\mathrm{V}$ - As grandes bandeiras. ${ }^{260}$

A questão das "origens portuguesas" aparece como ponto inicial da exposição desta seção, na explicação da palavra e do organismo bandeira: a partir de uma documentação "copiosa", apresentada "pela primeira vez" ao público

${ }^{260}$ CORTESÃO, J. et al. Introdução. In: Op. cit. [1954/1955], p. 5. 
conjuntamente. Segundo consta, desde 1570 a palavra bandeira era empregada como "sinônimo de companhia de Ordenanças ou de Milícias", entrando no Brasil via São Paulo em inícios do XVII, em um primeiro momento como organismo de defesa e posteriormente, de penetração territorial. Assim como evidenciou as origens portuguesas das bandeiras, o texto da introdução do catálogo destacou a contribuição indígena, que na exposição estava expressa em um grande painel. Diversos outros objetos expostos construiriam então uma narrativa pautada pela "continuidade cultural, inerente à formação luso-tupi do bandeirismo".

Tal parte da exposição, conforme sugere o mesmo texto, ia além do objetivo narrativo da "história de São Paulo no quadro da história do Brasil". De acordo com a linguagem utilizada, nota-se que as escolhas museológicas de Cortesão também pretendiam trabalhar problemas relacionados à produção do conhecimento histórico. Além do que já foi apresentado, nessa parte da exposição outra questão se pretendia esclarecida: a das fronteiras do Brasil. Os estudos de Cortesão apresentados em seus cursos no Itamaraty, bem como nas obras que resultaram de suas atividades naquela instituição se tornam centrais entre as quarta e sexta seções da exposição, dedicadas às bandeiras, à expansão e aos limites delineados do Brasil. Foi na quarta seção, por exemplo, que o mito da Ilha Brasil foi colocado como o ponto de partida das ações dos colonos, que então buscariam demonstrar a inviabilidade do Tratado de Tordesilhas. Cientes de uma unidade geográfica "brasileira", portugueses e lusobrasileiros teriam se dado conta de que os limites daquela terra nova "deveriam ser traçados em função das duas grandes bacias hidrográficas do Amazonas e do Prata", limites naturais daquela vasta unidade geográfica sul-americana. Cortesão atribuía então ao Estado português e aos colonos o sonho de "delimitar o Brasil por esses dois profundos acidentes geográficos e vales fluviais, nas suas possíveis conexões", sendo o mito da "Ilha Brasil" a primeira tentativa de solucionar o problema, encerrando em si todo um suposto "plano de expansão".

Diante do sonho, a realidade que se apresentava para aqueles colonos era a de que precisariam do conhecimento dos naturais da terra para nela se deslocarem, utilizando, por exemplo, os grandes rios, que seriam então as "estradas naturais". $\mathrm{Na}$ seção, o encadeamento da abordagem do assunto dá ênfase para o que seria a finalidade expansionista das bandeiras, apresentando por exemplo mapas que permitiam a visualização do que seriam o sistema "lógico e necessário das futuras fronteiras", incluindo os fossos e muralhas naturais impeditivos que, no entanto, 
foram ultrapassados por Raposo Tavares. Das derrotas sofridas pelos sertanistas, conhecidas por meio das narrativas jesuíticas que, como em Mbororé mencionavam a resistência indígena armada pelos padres castelhanos, é dito que os reais motivos do insucesso se deviam não à tenacidade dos nativos, mas sim o "excesso temerário da sua audácia [dos bandeirantes]", ultrapassando "os limites naturais impostos pela natureza". A unidade geográfica expressa na Ilha Brasil aparecia na exposição por uma profusão de mapas, atestando a sua transformação na cartografia oficial portuguesa e estrangeira.

A discutida motivação da preação de indígenas atribuída por parte da historiografia local às bandeiras e aos bandeirantes é mencionada, mas posta em segundo plano em relação aos objetivos políticos e econômicos das expedições, tratando por exemplo da atividade mineradora que tempos depois seria relevante. A questão da escravidão indígena, portanto, não seria destacada. Sobre outro ponto, relativo às motivações políticas das bandeiras durante o período da União Ibérica (1580-1640), negadas em diversas teses, Cortesão novamente dá o tom de debate que se travaria em torno da quarta seção, mencionando os erros históricos que teriam dado base às interpretações que ora desmentia. Segundo o organizador da exposição, a explicação de que a unificação das coroas sob o domínio filipino anularia pretensões políticas às bandeiras era negada a partir da documentação que atestava a manutenção dos termos de Tordesilhas bem como as condenações impostas por Filipe IV, em 1639, aos bandeirantes que ultrapassaram a linha demarcadora.

A chamada "lenda negra" que se produziu sobre os bandeirantes também fazia parte da seção, desconstruída por meio da apresentação das versões distintas apresentadas pelo jesuíta espanhol Montoya sobre a bandeira de Raposo Tavares no Guairá (1628-1629), destacando que por fim o padre mencionava as pretensões expansionistas do sertanista. Ao que se nota, pretendeu-se desmistificar a lenda desenhando os contornos do que seria uma guerra entre bandeirantes e jesuítas espanhóis. Segundo a documentação ora apresentada, a ação de Raposo Tavares contra as reduções seria uma reação à primeira investida armada feita por índios e jesuítas. Para ratificar a narrativa exposta, apresentavam-se ainda na seção mapas inéditos, como os que resultaram das bandeiras que devassaram o Tocantins e o São Francisco além dos documentos de origem jesuítica da Coleção De Angelis, sobre a qual Cortesão havia trabalhado na Biblioteca Nacional do Rio de Janeiro. 
A quarta seção apresentou em nove painéis e dez vitrines uma caracterização das bandeiras e dos bandeirantes. ${ }^{261}$ No painel de abertura, as relações entre portugueses em indígenas eram designadas como as matrizes das quais teria resultado aquele fenômeno, conforme apresentou a legenda, recebendo dos nativos o sentido de orientação e dos adventícios as finalidades econômicas e políticas. Esse painel, de Bernardo Marques (imagem 15), apresentava, junto das legendas, a origem da palavra e do organismo bandeira, caracterizando o fenômeno que aquela seção apresentaria. As legendas que comentam as imagens e o assunto apresentado na seção trazem trechos do Regimento dos capitães-mores e provisão sobre as ordenanças, $D$. Sebastião, 1570. Em questão, as definições do que seriam as "bandeiras de ordenanças", organismos militares.

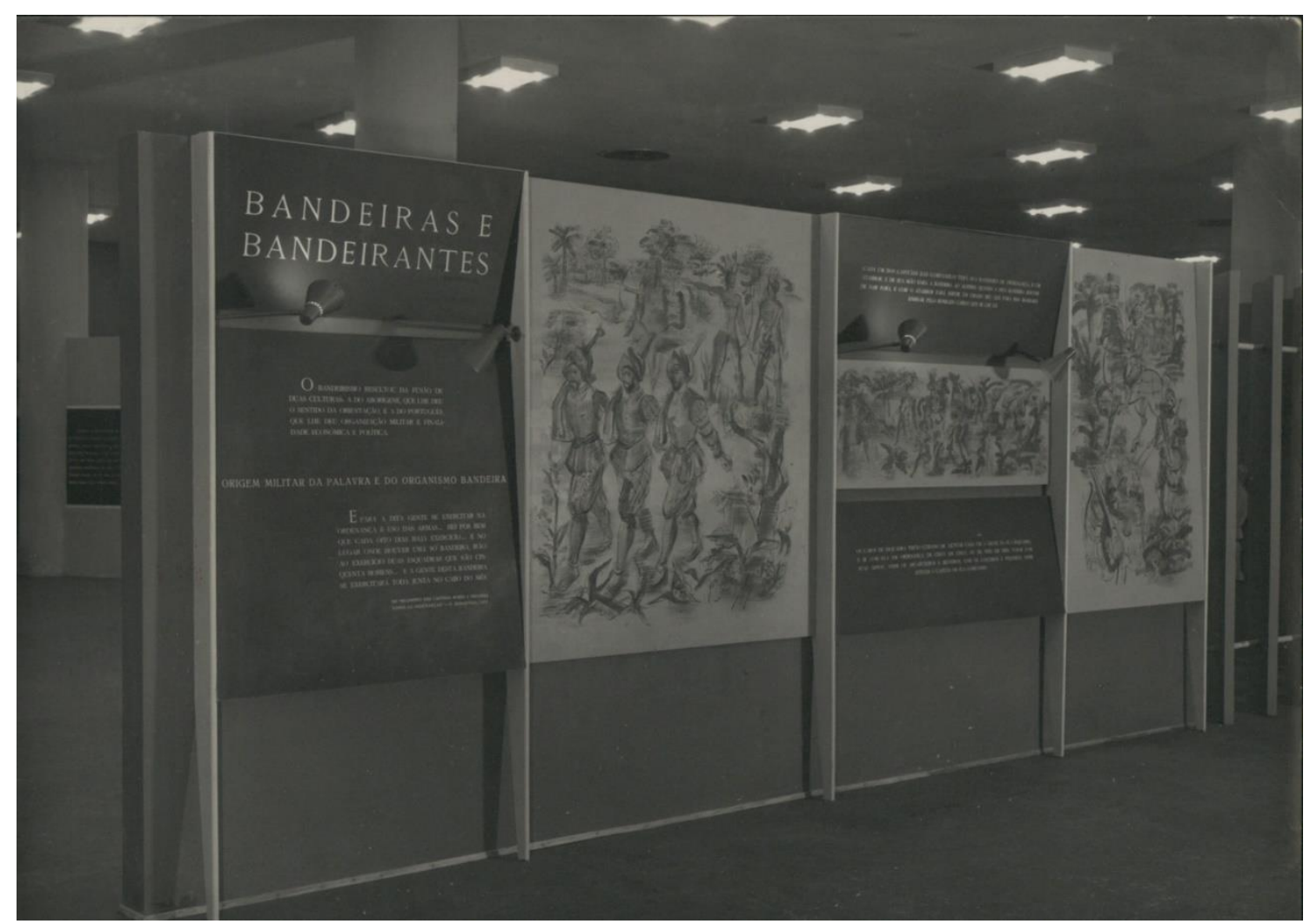

Imagem 15. IV Seção: painel de Bernardo Marques sobre a origem da palavra e do organismo bandeira. São Paulo, s/d. Fotógrafo não identificado. BNP/ACPC E25/1504.

Uma vitrine na sequência traria então o original do Regimento apresentado no painel de abertura, emprestado pela Biblioteca Pública e Arquivo Distrital de Évora, bem como fotocópias das folhas de rosto das edições do mesmo regimento nos séculos XVI e XVII, entre as quais as de 1623, 1624, 1642 e 1694. Desses documentos e de outros relativos aos mesmos tempos, legendas comentam sobre trechos em que

${ }^{261}$ CORTESÃo, J. et al. Seção IV - Bandeiras e bandeirantes. In: Op. cit., [1954/1955], 18 p. 
as bandeiras de ordenanças eram citadas em diversas regiões em que a presença portuguesa se fazia notar. Sintetizando o que se interpretou dos documentos a partir essencialmente do seu nome, uma citação era extraída dos Ensaios Sul-Americanos de Júlio de Mesquita Filho e posta junto aos documentos: "O bandeirismo, na sua essência, é um fenômeno eminentemente, visceralmente português". Com as contundentes palavras do editor d'O Estado de S. Paulo, o característico fenômeno da história paulista do qual se extraíram os heróis locais era filiado a Portugal.

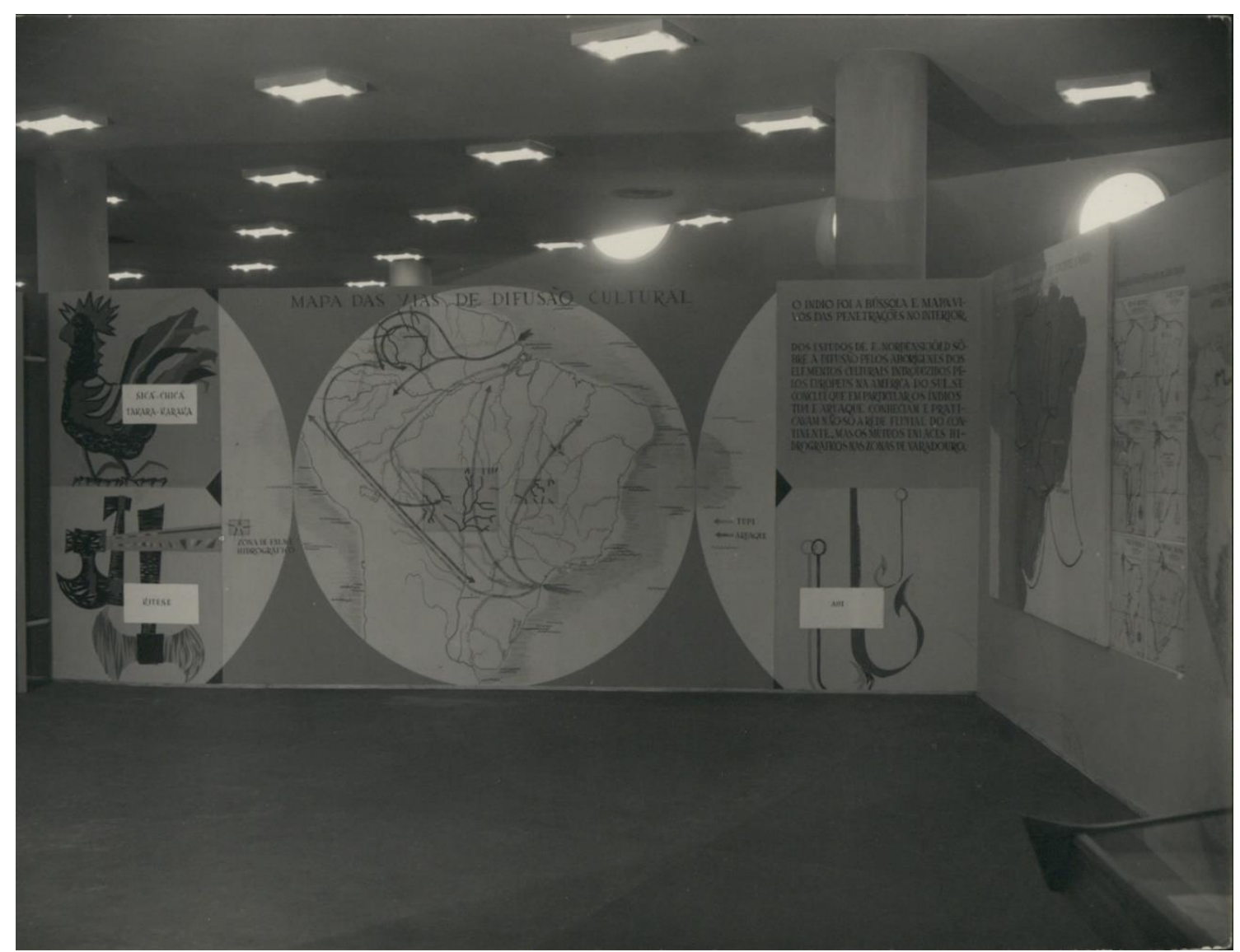

Imagem 16. IV Seção. Mapa das vias (indígenas) de difusão cultural. São Paulo, s/d. Fotógrafo não identificado. BNP/ACPC E25/1506.

Quanto às matrizes indígenas do mesmo fenômeno, o cartógrafo Ary Duarte produziu uma representação gráfica sobre um mapa da América do Sul identificando as vias indígenas de "difusão cultural", isto é, difusão dos principais elementos introduzidos pelos europeus nas Américas portuguesa e espanhola (imagem 16). Cores diferentes e traços esquemáticos distinguem as vias dos Tupi e dos Aruaque. Também representados estão, por uma convenção cartográfica, as zonas de "enlaces hidrográficos" que os índios teriam aproveitado para efetivar tal difusão. Entre os elementos, o painel traz o galo, os machados de ferro e os anzóis. Do lado direito do painel, a legenda caracteriza qual teria sido o papel desempenhado pelos indígenas 
nos deslocamentos para o sertão: "O índio foi a bússola e mapas vivos das penetrações no interior". Abaixo desse texto, uma outra legenda indica as fontes utilizadas para a produção daquele mapa - os estudos de Nordenskjöld - que tinha pesquisado sobre a difusão pela população nativa de elementos culturais pelos europeus na América do Sul. Na ocasião, concluiu em particular que os Tupi e Aruaque "conheciam e praticavam não somente a rede fluvial do continente, mas os mútuos enlaces hidrográficos nas zonas de varadouro". Tais estudos, como apresentei em outra parte deste texto, foram mobilizados por Cortesão quando trabalhou sobre os projetos sobre a nova capital do Brasil.

A fotografia que capturou o painel produzido a partir do trabalho do cartógrafo Ary Duarte (imagem 16), permite identificar à direita daquele painel o seguinte, que trazia diversos mapas. O primeiro, em tamanho maior, era um Esquema das estradas naturais de São Vicente e São Paulo para o Atlântico e para o interior. Ao centro do quadro, um conjunto de fotocópias "exemplifica a formação e evolução do mito da Ilha Brasil". Trata-se dos mapas de Diogo Ribeiro (1523-1527), André Homem (1559), Vaz Dourado (1568), João Teixeira (1630/1642) e Nicolau Sanson (1658). Por fim, um mapa intitulado Faixas e centros formadores das fronteiras da América Meridional é utilizado para apresentar os tão falados limites naturais que formariam a "unidade geográfica".

Em suma, os dois painéis montados lado a lado e as suas diversas representações cartográficas, na sequência da abertura que aludia às matrizes portuguesas e indígenas das bandeiras, qualificava ao visitante quais seriam aquelas matrizes, comunicando por meio dos mapas as apreensões de nativos e de portugueses daquele vasto território. Postos lado a lado, os mapas poderiam conduzir a uma leitura comparativa, que seria informada pelas legendas apresentadas, sugerindo uma harmônica simbiose a conceber a formação de um "território brasileiro". Para além disso, outra legenda ainda dava conta da "continuidade cultural, da linguagem náutica dos portugueses para a dos bandeirantes". Nesses termos, a expansão dos navegadores portugueses se transubstanciava nas incursões sertanejas, expressa também pelo uso de termos como "armar, armador e armação, navegar, descobrimento, roteiro, gerais, monções, ressaca, restinga": questão linguística apresentada por Cortesão em conferências e em textos. 
A cartografia histórica continua a se destacar nas vitrines seguintes, como os Atlas dos Teixeiras, de meados do século XVII, cedidos pela Mapoteca do Itamaraty. Deles se destaca o que se chama de "propaganda política" dos tempos da Restauração de Portugal (1640), criticando o "desleixo da Espanha" e as ameaças holandesas do território sob administração portuguesa. Em seguida, destaques do mesmo conjunto documental, de 1666, são expostos. Nas folhas soltas figuram regiões da costa vicentina. Partes do mundo também são apresentadas, dando conta das representações cartográficas seiscentistas.

Para demonstrar o "significado das bandeiras na história nacional", foram escolhidas "frases de valor épico", dispostas em um painel. Os padres jesuítas Diogo Ferrer e Manuel da Fonseca destacavam as adversidades às quais se sujeitavam os bandeirantes, chamados por Fonseca de "conquistadores deste Novo Mundo". Oliveira Martins registra o "espírito aventureiro dos paulistas" como "a primeira alma da Nação Brasileira e São Paulo", local de onde teria partido então o "movimento de ocupação dos sertões". Euclides da Cunha, por sua vez, deixou a opinião de que as entradas e a sua "tradição heroica" constituem "o único aspecto original da nossa história". A seguir, diversas armas de três séculos complementavam a heroica e aventureira epopeia. Cedidas por instituições como os museus Histórico Nacional, do Ouro de Sabará e Paulista, assim como de particulares como Amoroso Neto. Desenhos de Wasth Rodrigues explicitavam o uso daqueles instrumentos e um diorama de Wladimir Douchkine apresentava "bandeirantes em marcha no sertão, acompanhados por índios, um deles vestindo a típica couraça de algodão”. Dessa forma, com frases de efeito, armas e representações pictóricas, caracterizavam-se os bandeirantes.

As vitrines em seguimento traziam uma grande quantidade de mapas seiscentistas, reunidos em torno de uma legenda em que se caracterizava o período da unificação das coroas ibéricas sob o cetro espanhol e a manutenção dos termos de Tordesilhas. Traziam também documentos que a apresentar as tensões entre bandeirantes e jesuítas - espanhóis - e a chamada "lenda negra" que se constituiu a respeito dos sertanistas, entre eles as cartas do padre Montoya comentadas no texto introdutório do catálogo, como foi anteriormente citado. Os documentos sobre os quais trabalhou Cortesão na Biblioteca Nacional brasileira são acompanhados também por duas cartas pertencentes ao seu outro local de trabalho, a Mapoteca do Itamaraty, em que se representa a região das missões jesuíticas do Paraguai. Como 
fica manifesto em parte substancial das seções organizadas diretamente por Cortesão, as fontes e instituições em que trabalhou foram determinantes para o percurso estabelecido da exposição. Outras instituições em que Cortesão circulou, como o Instituto Histórico e Geográfico Brasileiro também deram a sua contribuição a essa seção, como nos mapas históricos da América do Sul que compuseram a vitrine posterior.

Com dois metros e meio de altura por quase dezessete de comprimento, mais um mural de Manuel Lapa se fazia presente, dessa vez apresentando uma bandeira em marcha. Segundo a descrição do catálogo, a bandeira era representada desde o momento da partida, "rompendo a selva, descendo os rios, transpondo as corredeiras e, no último trecho, em luta com os Guaicuru, índios cavaleiros do Mato Grosso, que constituíram, com os Paiaguá, um dos maiores adversários à marcha dos paulistas". A legenda que apresenta o grande mural sustenta a representação, citando ainda a chegada ao Prata, aos Andes, à foz do Amazonas: "molda, dando-lhe vida própria e épica, o Brasil". Sintetizada num mesmo mural, pela imagem e pela legenda, a "marcha dos paulistas" é monumentalmente celebrada, ao mesmo tempo em que identifica como seus "inimigos" aqueles índios que resistiram à presença bandeirante. O roteiro de Raposo Tavares, o mais extenso de todos, serve de base para o mural e para a legenda que o comunica.

Uma carta de marear de 1681, de autoria de José da Rocha Miranda e pertencente ao Museu da Marinha, de Lisboa, representa o Atlântico e os países banhados por ele. Ilustrações coloridas de animais, árvores e figuras simbólicas são abundantes, sendo que no Brasil está desenhada uma mulher com um cocar na cabeça, cavalgando um tatu. A figura feminina ainda traz numa mão um arco e na outra uma bandeira portuguesa com a Cruz de Cristo. Esse é um dos mapas e documentos do tempo das bandeiras, apresentados em um painel em que se destaca a expedição de Raposo Tavares. Entre os documentos, originais ou fotocopiados, havia também nesse painel mapas produzidos especialmente para a exposição, como um da série que mostra o traçado aproximado da cidade de São Paulo e seus arredores em 1654, feito pela equipe coordenada pelo engenheiro Gastão Bierrenbach de Lima. Além desse, outro do cartógrafo Ary Duarte apresentava o traçado das bandeiras de Antônio Raposo Tavares ao Guairá, ao Tape, a grande bandeira de 1648-1651, entre outras. De Taunay é a citação que acompanha o esquema: "A mais prodigiosa jornada de devassa de terras ignotas em qualquer 
tempo e qualquer continente jamais ocorrida". Ressalta-se ainda, na ocasião, que os jesuítas espanhóis - a despeito de todas as denúncias que fizeram e que pouco reverberaram na exposição - afirmaram que as bandeiras, em especial a de Raposo Tavares, "tiveram um caráter político e de reivindicação territorial, em nome da Coroa de Portugal e do Conde de Monsanto".

Mencionando a presença holandesa no Brasil, quadros de Franz Post, emprestados pelo Museu Nacional de Belas Artes e pelo Ministério das Relações Exteriores compõem o painel dedicado às "mais altas expressões da civilização europeia" dos tempos de Maurício de Nassau. Essa presença também foi expressa por mapas holandeses de propriedade da Mapoteca do Itamaraty e do IHGB, acompanhados por um retrato do próprio Nassau.

A última vitrine reunia diversos documentos do Arquivo Histórico do Ultramar e da Biblioteca Nacional brasileira referentes à segunda metade do século XVII, tratando de assuntos de São Paulo, de outras vilas brasileiras como Iguape e Paranaguá, do Paraguai e das bandeiras de Raposo Tavares. Finalizando a quarta seção, um painel indica o assunto sobre o que seria apresentado então na seção seguinte: a mineração. Depois da Restauração, o monarca D. João IV “dá novo e intenso calor à busca de minas na persuasão da existência de ouro no Brasil". Em 1642, assinala o painel, um grupo de representantes paulistas foi a Lisboa pedir ao Rei a instalação de uma Casa de Moeda. Nesse sentido, a apresentação do bandeirismo se sustenta na exposição sobre duas finalidades principais: a expansão do território e a corrida do ouro. As duas seções seguintes, ainda sob a orientação direta de Cortesão, se aprofundariam sobre essas duas questões.

\section{Seção V-A Capitania de São Paulo e a Expansão Mineradora}

Com o título "A Capitania de São Paulo e a Expansão Mineradora", a quinta seção dedica-se ao processo que "alarga-se de súbito em grandes proporções o quadro físico em que vai desenvolver-se a história de São Paulo", conforme indica o texto de introdução do catálogo da Exposição de História de São Paulo. Tal impulso não só "unifica o território e multiplica o povoamento" como também, a partir do afluxo de ouro e de poder, dá ao Brasil maior segurança, "pondo problemas que provocam uma renovação da cultura na metrópole". 
Fernão Dias Pais, "o governador das esmeraldas", destaca-se na abertura da seção. Para Cortesão, Fernão Dias é o "grande precursor" e a "mais isenta, heroica e dramática figura de bandeirante", abrindo o caminho para "a era das Minas Gerais". Talvez a maior das revelações da exposição, segundo os seus organizadores, sejam os trinta mapas inéditos de bandeirantes e sertanistas encontrados. Até aquele momento, afirma-se que não se conheciam, "no original, mapas típicos de bandeirantes e de sertanistas, onde, sobre os traços rudes, sentíssemos como que sair do Caos uma nova e vasta entidade geográfica". Acreditam, Cortesão e o seu grupo, ter conseguido "apontar com segurança alguns desses mapas, dum traçado mais que rudimentar, mas revelando extraordinárias qualidades de orientação e expressão cartográfica, como sendo obra de bandeirantes". Desses, destaca o Mapa geral da região das Monções de São Paulo a Cuiabá, de traçado primitivo e indicações sumárias da viagem pelos rios, em estilo retilíneo como nas cartas indígenas: tais características levam a atribui-lo a um autor bandeirante paulista de cerca de 1720. O documento é considerado como um dos grandes "monumentos" da exposição, de acordo com a apresentação que se faz na introdução do catálogo.

As capitanias de Minas Gerais, Goiás e Mato Grosso, formadas a partir da primeira metade dos Setecentos, atestariam a grandiosidade das expedições em busca de ouro, movimento este que colocaria a metrópole na posição de buscar resolver os problemas de soberania frente a América espanhola e ao Tratado de Tordesilhas. $\mathrm{O}$ monarca D. João V e seus conselheiros promoveriam então, antes da Espanha, a renovação dos estudos astronômicos e cartográficos, enviando em 1729 a Missão dos Padres Matemáticos que traçariam o Novo Atlas do Brasil, com o objetivo de fixar a situação do Meridiano de Tordesilhas por meio de longitudes observadas. Os trabalhos resultantes da missão, muitos dos quais se expuseram na quinta seção, "estabeleceram as bases científicas sobre as quais o genial paulista de Santos, Alexandre de Gusmão, virá a criar e negociar o Tratado de Madri”.

No segmento da seção dedicado às monções, poucos documentos inéditos sempre destacados seja pelo catálogo, seja pelos anúncios da exposição feitos na imprensa - foram apresentados. O objetivo foi o de "tornar vivo o valor épico das jornadas monçoeiras e a importância que toma, nessa época, o Tietê com suas lendas". Também grande visibilidade teve a questão das disputas pela Colônia do Sacramento, cercada e assaltada por castelhanos de Buenos Aires e jesuítas 
missioneiros, o que se aponta como um importante evento no "processo histórico da formação territorial do Brasil".

Na seção, os documentos são expostos de modo a ilustrar o nascimento de um sentimento de "pátria nova", fruto da expansão mineradora e dos sujeitos "enobrecidos pela ação épica" e que criavam uma "consciência de grupo social" e reclamavam vantagens. Desse sentimento, não apenas dos paulistas envolvidos na mineração, se sobressai o sermão do padre Bartolomeu de Gusmão, de 1717. A criação da Capitania de São Paulo, bem como o seu alargamento aos atuais limites ocidentais do Brasil, a criação da Diocese Paulista, o esplendor do culto religioso e certas expressões religiosas e culturais, típicas das regiões auríferas são também documentalmente ilustradas.

Ao longo de 14 painéis e dez vitrines, a quinta seção da Exposição de História centra-se na "expansão mineradora" para narrar especialmente o século XVIII. ${ }^{262}$ Nesse período, a vila de São Paulo é elevada à categoria de cidade (1711) e, de acordo com os estudos de Cortesão sobre Alexandre de Gusmão e o Tratado de Madrid (1750), a exploração do ouro teria permitido uma "renovação" na metrópole, viabilizando a supressão dos termos do Tratado de Tordesilhas e o novo delineamento dos limites "brasileiros" com o Tratado de Madri, assinado em 1750. O assunto da "formação dos limites" ganharia toda uma seção, logo a seguir.

A ideia comunicada por meio de uma legenda no painel de abertura da seção reforçava o mote da exposição, da "unificação do território" além de ir ao encontro do ufanismo paulista que era respirado naquelas comemorações. Qualificando a expansão mineradora como "dos paulistas", o texto posto conferia a esses a liderança do impulso "que unificou o território e multiplicou o povoamento", dando ainda ao Brasil, "com o súbito afluxo do ouro e do poderio, a consciência mais segura de uma entidade econômica, social e política, capaz de governar-se a si própria". De tal modo, conduzia-se à interpretação segundo a qual o germe da autonomia brasileira seria fruto do expansionismo "paulista".

A profusão de objetos expostos é maior da quinta seção em diante, provavelmente por conta da crescente aproximação temporal com o presente. Onze mapas setecentistas brasileiros são expostos na primeira vitrine, majoritariamente

${ }^{262}$ CORTESÃO, J. et al. Seção V - A Capitania de São Paulo e a Expansão Mineradora. In: Op. cit., [1954/1955], 38 p. 
pertencentes à Biblioteca Nacional do Rio de Janeiro. Entre eles alguns esboços e "borrões" sertanistas, cartografando sobretudo as regiões auríferas. Outros dezessete mapas foram expostos nas vitrines seguintes, também na maior parte cedidos pela mesma instituição. Grande parte apresenta a região das monções de Porto Feliz a Cuiabá e outras áreas de mineração. Dá-se destaque aos que indicam "os conhecimentos geográficos dos bandeirantes desde meados do século XVII aos meados do século XVIII, alguns deles amplamente descritos no catálogo. Em outras duas vitrines foram expostos documentos, notadamente oficiais, que compõem um quadro das atividades econômicas, políticas e sociais relativas ao período da mineração. São em sua maioria petições e cartas régias, contratos e correspondências, relativos aos descobrimentos de minas e também a questões como o cativeiro de índios na vila de São Paulo.

Salomão de Vasconcelos, da equipe de colaboradores da exposição, recompôs o traçado da rota da bandeira de Fernão Dias Paes em busca de esmeraldas, indicando pousos, feitorias e arraiais deixados pela expedição. Dois desenhos do artista português Fernando Lemos representam no painel uma paisagem mineira e a agonia de Fernão Dias no sertão.

Vitrines e painéis expunham ainda documentos relativos a regiões como a platina Colônia do Sacramento e outras partes da costa e do "sertão do Brasil", como um mapa provavelmente de 1704 de "excepcional valor para o estudo dos caminhos de penetração de São Paulo em direção às minas e a localização dos primeiros achados da região dos Cataguases". Além disso, os ataques franceses ao Rio de Janeiro não ficam alheios à narrativa, destacando-se dos mapas referentes a esses eventos seus parcos "conhecimentos geográficos" dessa parte da América do Sul, indiretamente comparados aos brasileiros e aos portugueses.

Do Museu Paulista, fez parte da mostra uma arca de madeira de 1738, que serviu de cofre a Clemente Carlos de Azevedo Cotrim "juiz de órfãos trienal nesta cidade [de São Paulo]", cujo nome, profissão e finalidade do objeto aparecem inscritos junto das armas de D. João V. O Museu do Ouro de Sabará, que cedeu diversas peças à exposição, teve figurando nessa parte da seção um almofariz utilizado em mineração. 


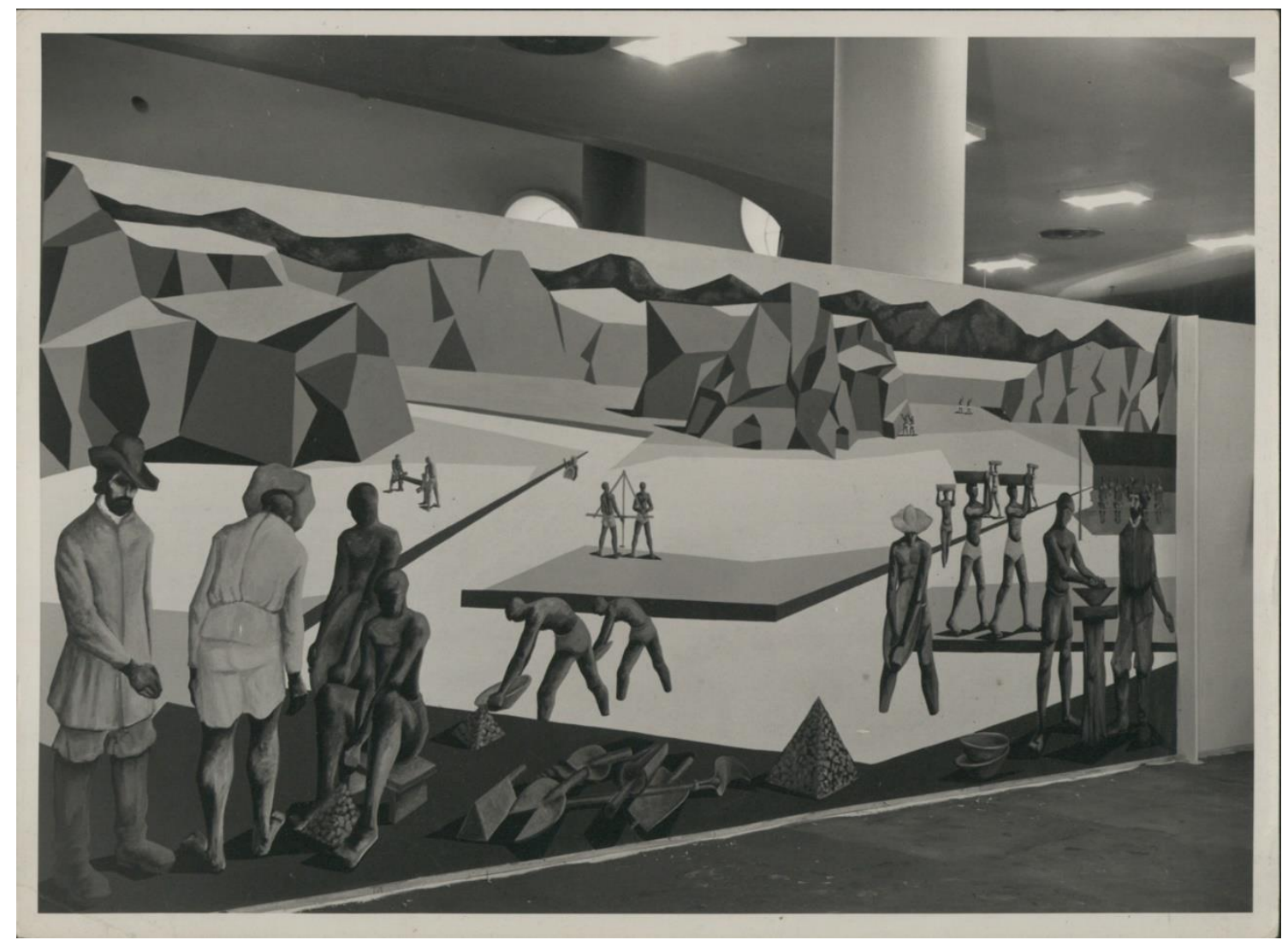

Imagem 17. Painel de Clóvis Graciano representando a mineração em um rio de montanha. São Paulo, 13 set. 1954. Fotógrafo: Bernardelli. BNP/ACPC E25/1507.

Um mural de Clóvis Graciano - artista que ilustrou o livro de Ernani Silva Bruno lançado sob o selo oficial das comemorações do quarto centenário de São Paulo - representa a atividade mineradora em um rio de montanha. $\mathrm{Na}$ obra (imagem 17), os objetos utilizados na lida do ouro aparecem em destaque, compondo o cenário do qual faziam parte alguns deles, emprestados pelo Museu do Ouro de Sabará e que não foram capturados pelo fotógrafo. A figuração dos homens portugueses ou luso-brasileiros é a única em que se distingue a fisionomia do rosto, assim como são os únicos elementos humanos a portar vestimentas. As figuras humanas dos mineradores parecem nuas ou seminuas, sem o rosto delineado, sugerindo ao visitante uma leitura que dê mais relevância à atividade desempenhada, aos homens que a "supervisionam", aos objetos, à paisagem. Os trabalhadores formam um conjunto igualitário.

Os assuntos sobre os quais Cortesão trabalhou em Alexandre de Gusmão e o Tratado de Madrid (1750) passam a figurar no painel dedicado à Missão dos Padres Matemáticos. Domingos Capacci e Diogo Soares receberam em 1729 o encargo de firmar a posição exata do Meridiano de Tordesilhas e traçar o Novo Atlas do Brasil, trabalhos esses que "estabeleceram as bases científicas do Tratado de Madri", 
conforme indicava a legenda que acompanhava prováveis e confirmados registros cartográficos daquela expedição, entre outros, expostos então naquele painel.

$\mathrm{O}$ assunto das monções foi a partir de então apresentado, iniciado por uma maquete produzida pelos "artistas da exposição", a representar pormenorizadamente a "estrada fluvial" de Porto Feliz a Cuiabá. Em seguida, dois desenhos do artista Fernando Lemos reproduziam um aspecto urbano de Cuiabá bem como uma paisagem do rio Tietê, vista do alto do embarcadouro de Porto Feliz. Do rio que corta São Paulo até desaguar no rio Paraná, um painel apresentava as suas lendas e prodígios, contados num mural de Arcindo Madeira, remetendo a figuras como Anchieta e Frei Galvão, canoas fantasmas, Iaras, cobras gigantes.

A Prefeitura da cidade paulista de Porto Feliz cedeu à exposição um batelão das monções, escavado em um só tronco e medindo pouco mais de nove metros de comprimento, por 1,25 de largura e um metro de altura. Na legenda que acompanhava a embarcação, dava-se tom épico às expedições, comparando os seus perigos aos que eram corridos pelos navegantes das viagens entre Lisboa e a Índia: novamente, induzia-se à comparação entre o expansionismo marítimo português e o fluvial/terrestre pelos caminhos sul-americanos. Catorze mapas e documentos foram dispostos em duas vitrines dedicadas a Goiás e ao Mato Grosso e às incursões feitas para aquelas regiões ao longo do século XVIII, entre eles um mapa produzido por Ary Duarte para a exposição demonstrando as Bandeiras de Ligação entre o Prata e o Amazonas, lideradas por Manoel Feliz de Lima (1742) e João de Souza Azevedo (1747).

Para apresentar os documentos da região das Minas Gerais, expôs-se um quadro de madeira entalhada em baixo relevo do "barroco primitivo", cedido pelo Museu do Ouro de Sabará. A peça fazia parte, segundo consta, da Igreja Matriz daquela cidade mineira. Dos documentos expostos na vitrine, apresentaram-se o Livro dos Termos do Governo de Minas, da administração da Capitania de São Paulo e Minas de Ouro, criada por Carta Régia de 1709, e a Carta Real de 24 de junho de 1711 permitindo que se chame de "cidade" a vila de São Paulo.

A chamada "renovação da cultura em Portugal", operada durante os reinados de D. João V, D. José I e D. Maria I, graças aos estrangeirados - os portugueses que se formavam em outros países - permitiu à metrópole, segundo a legenda do painel destinado a comunicar aquele fenômeno, "dirigir com eficácia a 
definição e defesa dos justos limites do Brasil", dando "de novo a São Paulo um lugar proeminente nessa fase da história do Brasil". A questão da formação dos limites aparece inserida no quadro das transformações ocorridas em Portugal nos tempos da "renovação da cultura". A partir de uma gravura de Debrie, de 1742, representando as "quatro partes do mundo" como homenagem a D. João V, a renovação que se dava nas culturas geográfica, astronômica e cartográfica era celebrada, demonstrando-se então que as "novas ideias", vindo sobretudo da França e da Inglaterra, "refletiram-se em Portugal por vários modos", entre eles a criação das academias e o desenvolvimento da diplomacia, figurando Alexandre de Gusmão em uma lista de homens encarregados de tratar da "defesa dos limites portugueses na América do Sul".

Caminhando para o final do percurso daquela quinta seção, um painel traz um grande mapa denominado Esquema Geral das Bandeiras Paulistas, feito especialmente para a exposição por Fukugawa Akira conforme orientação de Jaime Cortesão. Em cores diferentes, assinalam-se no mapa os traçados das bandeiras em cada século. Na sequência, fotocópias de mapas hidrográficos do Serviço Geográfico do Exército Brasileiro apresentam a costa da capitania de São Paulo com instruções náuticas minuciosas para navegar. Trata-se de mapas-roteiros que evidenciam o crescimento da navegação entre o Rio de Janeiro e Santos, bem como entre esses e os portos do Sul até o Prata. Ainda nesse painel, um novo mapa da série executada pela equipe do engenheiro Gastão César Bierrenbach de Lima mostra o traçado aproximado de São Paulo e arredores em 1754, na metade do percurso cronológico entre a "fundação" da cidade e a exposição.

$\mathrm{Na}$ conclusão da seção dá-se relevo às festividades e ao culto católico em São Paulo em meados do XVIII, assim como se apresenta um exemplar original, emprestado pelo Arquivo Nacional da Torre do Tombo, da bula papal Candor Lucis Aeternae. O documento de fins de 1745 erigia os bispados de Mariana e de São Paulo e as prelazias de Goiás e Cuiabá. Diversas imagens religiosas, como de anjos e de santos, cedidas pelo Museu da Cúria Metropolitana de São Paulo e pelo Museu Paulista, participam da representação plástica da vida religiosa setecentista.

O painel de encerramento da seção é um mural de Tarsila do Amaral (imagem 18), no qual se representa uma procissão de Corpus Christi na São Paulo de meados dos Setecentos, próximo de uma imagem de São Jorge em madeira, desmontável, e 
que era conduzida a cavalo nessas mesmas procissões. O cavalo com a representação do santo "montada" sobre ele figura no mural de cores vibrantes da artista modernista, onde são também identificáveis as coloniais igrejas da Sé e de São Pedro, ambas no Largo da Sé de São Paulo. Próximas às crianças vestidas de anjos, à direita da imagem, figuram uma mulher e duas crianças negras, aparentemente assistindo ao cortejo composto por homens de azul a trazer o cavalo, que segue à frente do padre com o ostensório, sob o pálio sustentado por um outro grupo masculino.

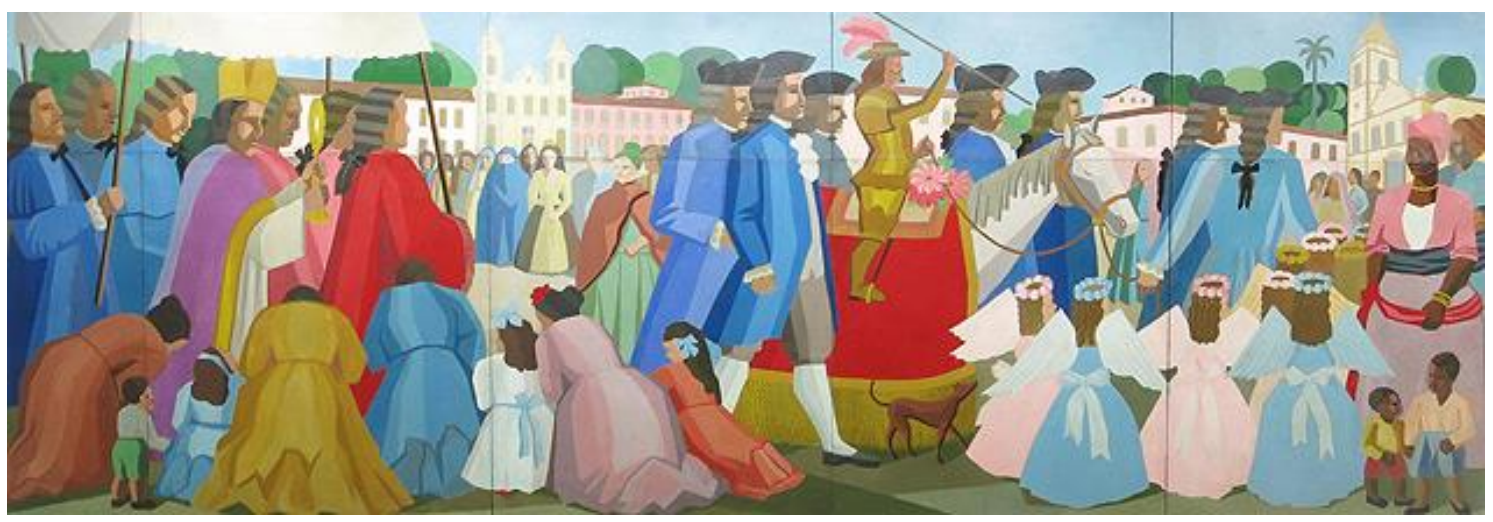

Imagem 18. Parte do mural de Tarsila do Amaral. In: MARTÍ, S. Mural esquecido de 1954 é descoberto atrás de uma parede falsa na Oca. Folha de S. Paulo, São Paulo, 13 jul. 2015. (Imagem da Coleção de Arte da Cidade/ CCSP).

Uma vitrine, enfim, expunha cinco aquarelas originais, do século XVIII, de um artista português. Nelas, "danças negras de congada" estavam registradas, cerimônias "em que os negros e as negras fundem ritos católicos e ritmos africanos". Apesar de essas terem sido algumas das mais frequentes manifestações religiosas e culturais das regiões de mineração, apenas cinco pequenas aquarelas faziam-nas presentes na grandiosa exposição.

\section{Seção VI - São Paulo e a formação dos limites do Brasil}

A sexta seção foi a última organizada diretamente por Cortesão. No texto introdutório, ela é descrita como aquela que diz respeito às "consequências do bandeirismo nas relações políticas entre Portugal e a Espanha e das suas profundas repercussões na Metrópole e na América”. Cortesão menciona a renovação cultural em Portugal, intimamente relacionada aos problemas da "formação territorial brasileira" e seguindo uma nova mentalidade, racionalista, matemática e naturalista, importada de outros lugares, trazidas, como anunciado na seção anterior, pelos estrangeirados. Como representativo desse momento, Cortesão escolhe o engenheiro- 
mor Manoel de Azevedo Fortes, inspirador da renovação do ensino da engenharia militar portuguesa, que ensejou por sua vez a formação de uma diversidade de engenheiros e cartógrafos que viriam a ser importantes tanto na definição quanto na defesa dos limites do Brasil. Ao engenheiro-mor do Reino e ao Secretário de Estado Diogo de Mendonça Corte Real foi dedicado o painel de abertura da seção.

Dos estrangeirados que assumiram importância em Portugal, Cortesão fala dos luso-brasileiros, paulistas quase na totalidade: Bartolomeu de Gusmão, Alexandre de Gusmão e o Padre Inácio Rodrigues, os três santistas. Além deles, Teresa Margarida da Silva e Orta, escritora, e seu irmão, escritor "filosofante" Matias Aires, paulistas, têm grande interesse, sobretudo o segundo, também arquiteto, após o terremoto de Lisboa. Além desses, o fluminense Antônio José da Silva renovou o teatro português com as suas óperas.

Ao que indica o tom dado no texto de introdução, a intenção de Cortesão na sua última seção foi a de conferir grande relevo ao "verdadeiro homem representativo" que foi Alexandre de Gusmão e ao seu feito do Tratado de Madri. Mapas portugueses e estrangeiros comporiam, então, os antecedentes daquele acordo e explicariam os esforços do diplomata para a execução do Tratado que revogava o de Tordesilhas, lançando mão das inovações científicas e jurídicas de seu tempo. De acordo com o texto, a centralidade que a exposição conferia ao Tratado de Madri o sentido de "sanção jurídica à expansão paulista", recorrendo ao espírito de fronteira - a "consciência dos limites necessários, justos e invioláveis", conceito cunhado pelo geógrafo Vidal de La Blache, necessário à formação dos Estados. Nesse sentido, o Mapa das Cortes ganha foros de "monumento cartográfico" na exposição, figurando de diversas formas, para comunicar diversas leituras.

A tese de Cortesão do "bandeirismo dirigido" era apresentada. Segundo o organizador da exposição, o fenômeno que a partir da segunda metade dos Setecentos transformaria o "bandeirismo livre" estava "enquadrado nas atividades gerais do Estado, e tornado científico, graças à renovação da cultura em Portugal, de que tantos e tão ilustres paulistas (...) partilharam". Dessa forma, apesar de reconhecer a liderança e a iniciativa paulistas, o historiador conferia maiores consequências às ações referentes ao território coordenadas pela Coroa, como se o Estado Português tivesse seguido pelas veredas abertas pelos bandeirantes. Como grande agente de transformação desse novo impulso, Cortesão qualifica o Morgado 
de Mateus, à testa da Capitania de São Paulo, restaurada em 1765. Segundo comenta, a restauração teria obedecido à necessidade "de ocupar e defender as fronteiras meridionais do Brasil, postas de novo em causa, após o Tratado do Pardo (1761)". O novo governante, teria sabido, segundo o citado Machado de Oliveira, "ressuscitar nos paulistas o prurido das lides nas matas de que apenas tinham leves recordações". Acrescenta Cortesão que embora a frase estivesse longe de corresponder à verdade, é lícito caracterizar um revigoramento do bandeirismo, "sistematicamente dirigido, sob disciplina militar, para objetivos de reivindicação territorial, ou quando transformado em expedição científica".

Ancorando-se sobre essas bases, a sexta seção destaca-se das demais organizadas por Cortesão, contando 20 vitrines e doze painéis. ${ }^{263}$ Junto do painel de abertura, dedicado ao engenheiro-mor e ao Secretário de Estado do reinado de D. João V, Oito mapas setecentistas de várias regiões do Brasil foram expostos na primeira vitrine da seção, apresentando o quadro dos conhecimentos geográficos sobre o continente nos anos que envolvem o Tratado de Madri. Entre esses mapas, estava o de Francisco Tosi Colombina de 1751, mostrando a comunicação entre as bacias do Prata e do Amazonas, documento que foi amplamente utilizado nos estudos de Cortesão para o debate sobre a construção da nova capital do Brasil.

Para expor o contexto intelectual do Tratado de Madri, uma vitrine apresentava diversos livros publicados à sua época, entre os quais a dissertação francesa de Delisle L'Ainé intitulada Determination geographique de la situation et de l'etendue des differentes parties de la Terre, trabalho que teve grande repercussão nos estudos geográficos e cartográficos portugueses. Conforme a legenda a organizar a interpretação dos exemplares dispostos, o grupo social dos estrangeirados, formado por luso-brasileiros, quase sempre paulistas, foi iluminado pelo "inconformismo e espírito de reforma", que fez despontar o "sentimento de pátria brasileira" que se generalizaria e se faria presente nos crescentes protestos contra o absolutismo. Além disso, outra legenda comunicaria ainda nessa vitrine o termo "expansão paulista", que apesar de exceder a demarcação imposta por Tordesilhas tinha ocupação limitada. Tal expansão, contestada pela Espanha, urgia uma "sanção diplomática" sobre novas bases. Foi assim que o Tratado de Madri foi concebido, orientado pelos

${ }^{263}$ CORTESÃo, J. et al. Seção VI - São Paulo e a formação dos limites do Brasil. In: Op. cit., [1954/1955], $62 \mathrm{p}$. 
princípios do uti possidetis e dos limites naturais: dessa forma, a legenda - bem como a sexta seção como um todo - definia as bandeiras paulistas como prefiguração do Brasil, dando sentido à "expansão paulista" como esforço definidor das fronteiras brasileiras. Cabia então naquele momento, dar amplo destaque ao homem - paulista de Santos - que teria compreendido tal sentido e lhe dado valor jurídico, transformando a ação bandeirista na letra do tratado assinado em 1750 .

Alexandre de Gusmão (1695-1753) e o Tratado de Madri (1750), sujeito e assunto sobre os quais Cortesão dedicava muitos de seus estudos há anos, eram o tema das vitrines e painéis registrados na fotografia a seguir (imagem 19). De acordo com o percurso identificável no catálogo, a sequência da exposição está, na imagem, da direita para a esquerda. Seguindo a sequência, a primeira vitrine traz dois volumes da obra Alexandre de Gusmão e o Tratado de Madrid (1750), bem como fotocópias da assinatura de Alexandre de Gusmão e de documentos produzidos ou pertencentes ao diplomata. Ao lado da vitrine, o retrato é de $\mathrm{D}$. Luiz da Cunha, embaixador que representou Portugal em vários países, identificado como "mestre e precursor de Alexandre de Gusmão". Assim como na seção anterior, destaco que no catálogo tornam-se frequentes comentários sobre objetos expostos que extrapolam as legendas, demonstrando familiaridade entre Cortesão e aquelas que são também as fontes de suas pesquisas.

O painel que ocupa o centro da imagem é composto por um mural de João Maria dos Santos representando a assinatura do Tratado de Madri, produzido de modo a figurar como se tivesse ao fundo o Mapa das Cortes. O mapa é sobreposto a um do Brasil contemporâneo, concorrendo assim tanto para a comparação entre ambos os contornos quanto para referendar as teses apresentadas até então do delineamento das fronteiras brasileiras pelos paulistas, sejam eles bandeirantes ou diplomatas. Logo acima do busto de Alexandre de Gusmão, pertencente ao Ministério das Relações Exteriores, uma legenda está inscrita sobre o mural e sobre a parte em que está o mapa, celebrando o diplomata. $\mathrm{Na}$ inscrição, registra-se que apesar de secretário real, Gusmão tinha sido "um panfletário ardente contra o regime absoluto de Portugal". Além disso, assinala-se que devido à sua "cultura típica de 'estrangeirado', e às suas funções de secretário real, torna-se a consciência política dos problemas da formação territorial do Brasil, que resolveu em bases novas com o Tratado de Madrid, de que foi o inspirador e negociador oculto". 


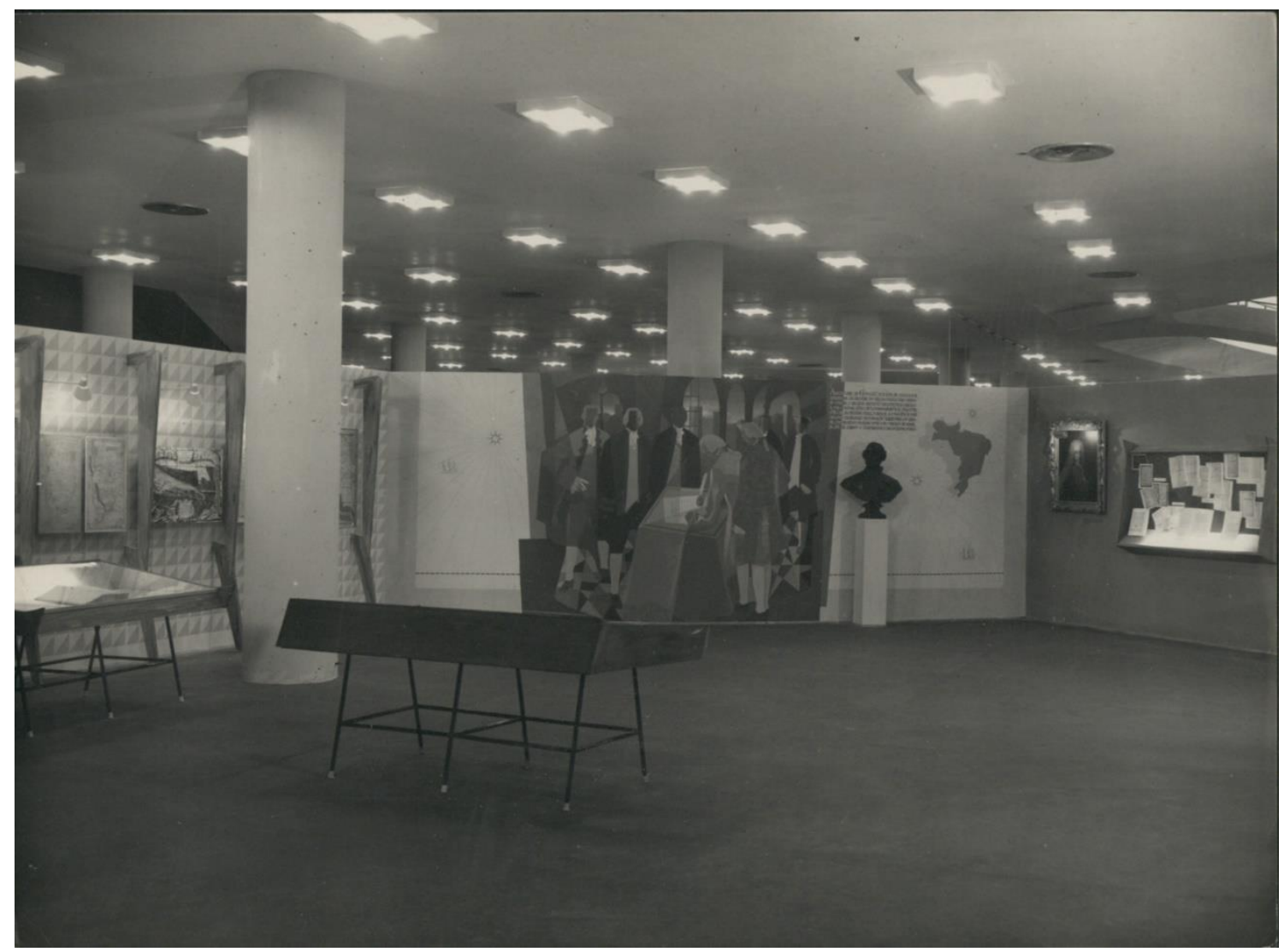

Imagem 19. Seção VI. Busto de Alexandre de Gusmão e painel sobre assinatura do Tratado de Madri (1750). São Paulo, s/d. Fotógrafo não identificado. BNP/ACPC E25/1508.

$\mathrm{Na}$ sequência, também compreendida na imagem acima, apresentam-se documentos relativos ao Tratado de 1750, sobretudo cartográficos, que demonstram o cumprimento dos termos do acordo, tais como as expedições para fixar os marcos demarcatórios das fronteiras. Cópias do Tratado, exemplares do Mapa das Cortes, desenhos das regiões limítrofes entre as terras portuguesas e espanholas, entre outros documentos similares, estão provavelmente contidos nas outras duas vitrines que compõem a fotografia. Esta imagem pode, portanto, ter enquadrado completamente a parte da exposição diretamente referente a Alexandre de Gusmão e o Tratado de Madri. Parte essa, de acordo com a concepção de Cortesão, que encerraria o sentido maior da ação "paulista" para definir os limites do Brasil.

No quadro da renovação cultural portuguesa, complementa-se com a exibição de um retrato do Marquês de Pombal, do século XVIII, emprestado pelo Itamaraty. A legenda que acompanha o retrato do Sebastião José Carvalho e Melo, o Secretário do Reino de D. José I, destaca algumas das ações motivadas por sua influência e pelas chamadas "ideias novas", como a abolição da Companhia de Jesus, a reforma da Universidade de Coimbra, a modificação das Ordenações Régias, o fim da escravidão na metrópole e a subordinação das sentenças da Inquisição à confirmação 
régia. Dessa forma, a sua personalidade era lembrada no percurso sem concorrer com o protagonismo de Alexandre de Gusmão ou de outros homens do tempo da dita "renovação da cultura".

Prosseguindo com a exibição de peças brasileiras, caracterizando a vida setecentista na colônia, expuseram-se quinze aquarelas de um artista português não identificado, representando tipos e costumes brasileiros. Do cotidiano também foi exposto um cofre de ferro da Provedoria de São Paulo, pertencente ao Museu Paulista. Ainda nesse sentido, mapas e vistas da região da cidade de São Paulo, bem como de São Vicente, Curitiba, entre outras, cedidas pelos Arquivo Histórico e Mapoteca do Itamaraty, se fizeram presentes em uma vitrine.

Para dar relevo à administração do Morgado de Mateus, administrador da Capitania de São Paulo a partir de 1765, um painel buscou apreender a região sob seu governo. Para tanto, além de uma ampliação colorida de uma vista de Santos àquela época, o artista Wasth Rodrigues fez seis aquarelas especialmente para a mostra, representando os figurinos militares em uso na Capitania. Como se apresentou no texto introdutório do catálogo, uma legenda fazia compreender que a restauração da Capitania de São Paulo, depois do período em que foi dissolvida e posta sob a administração do Rio de Janeiro, teria acontecido principalmente para atender à necessidade de "ocupar e defender as fronteiras meridionais do Brasil". Uma lacuna, no entanto, não permite ao visitante compreender o motivo da dissolução e do posterior restabelecimento da Capitania.

Segundo se comunica, o governador Luiz Antônio de Souza Botelho Mourão, o Morgado de Mateus, teria sabido fazer reviver o "espírito das bandeiras", conforme a citação de Machado de Oliveira, além de ter promovido o "redescobrimento dos sertões do Tibagi, dos rios Ivaí, Iguaçu, e campos de Guarapuava, exploração de conjunto em que o Bandeirismo reviveu". Um diorama feito por Wladimir Douchkine representava o governador instruindo os novos regimentos paulistas no exercício das armas, tendo ao fundo a cidade de São Paulo conforme o desenho por ideia ampliado no painel seguinte, de cerca de 1770, do original presente em um arquivo particular português. Documentos referentes às ações do governante foram apresentadas em uma vitrine, perto de onde também se via um retrato a óleo do governante pertencente ao Conde de Mangualde, quinto neto do retratado. 
Trinta e um documentos, majoritariamente cartográficos, portando sobre as monções, o sul da América Portuguesa, a fortaleza de Nossa Senhora dos Prazeres do Iguatemi, entre outros espaços, foram dispostos em quatro vitrines e um painel. Das informações oferecidas pelas legendas que acompanham esses documentos, uma cita a motivação da fundação da fortaleza de Iguatemi, de "consolidar e estender a soberania portuguesa nos territórios ocidentais". A fortaleza, em região hoje correspondente ao estado do Mato Grosso do Sul, teria sido, segundo apresenta a legenda, "glória e sorvedouro de vidas paulistas". Além disso, expôs-se então sobre a Expedição Filosófica, composta por uma "plêiade muito notável de cientistas brasileiros" que "concorreu para dar configuração científica aos traços gerais da geografia do Brasil".

Caminhando para fins do século de Setecentos, a documentação sobre as regiões das minas e as fronteiriças também apresentam o novo tratado de limites, o de Santo Ildefonso (1777), que segundo uma das legendas traria, com a sua execução "o último surto do bandeirismo paulista", por sua vez "dirigido e com caráter científico". Uma vitrine com diversos mapas e documentos relativos às expedições do paulista Francisco José de Lacerda e Almeida, um dos executores do Tratado de Santo Ildefonso, conduzem à interpretação de que as bases das expedições em terras da América Portuguesa abriram caminho para explorações em outras paragens sulamericanas e também africanas, notadamente nos rios de Sena, Moçambique. Lacerda e Almeida era identificado como astrônomo e naturalista: o "bandeirante tornado homem de ciência" é o autor do "traçado científico (...) da estrada das Monções", que em parte foi exposta em um painel.

Uma vitrine a seguir dá conta da região amazônica, explorada pela Expedição Filosófica. Além dos mapas, apresentam-se também desenhos de animais, armas, instrumentos musicais e mecânicos, ornatos, utensílios domésticos, bem como os índios que eram produtores desses objetos. Desenhos apresentavam também a forma de construção de canoas e as habitações daquelas regiões. O mural de Artur Jorge apresenta, junto desses documentos, a Expedição Filosófica dirigida por Alexandre Rodrigues Ferreira, o "Humboldt brasileiro", na bacia amazônica. Essa parte da exposição, retratada na fotografia capturada no dia de sua inauguração solene (imagem 20), permitia também que "no quadro da história do Brasil" se visualizassem permanências da ação das bandeiras, das monções, das expedições 
filosóficas e mesmo da expansão marítima portuguesa. O grande quadro composto dentro da Oca compunha, ao menos até a sexta seção, similaridades e continuidades de navegações por mar e por rios, sob o signo de bandeiras portuguesas: à luz das constelações e da observação de latitudes e longitudes, ampliando o conhecimento geográfico expresso pela vastíssima documentação cartográfica exposta, a mostra reforçava laços luso-brasileiros por meio da narrativa da história de São Paulo e de seu maior símbolo, as bandeiras e os bandeirantes.

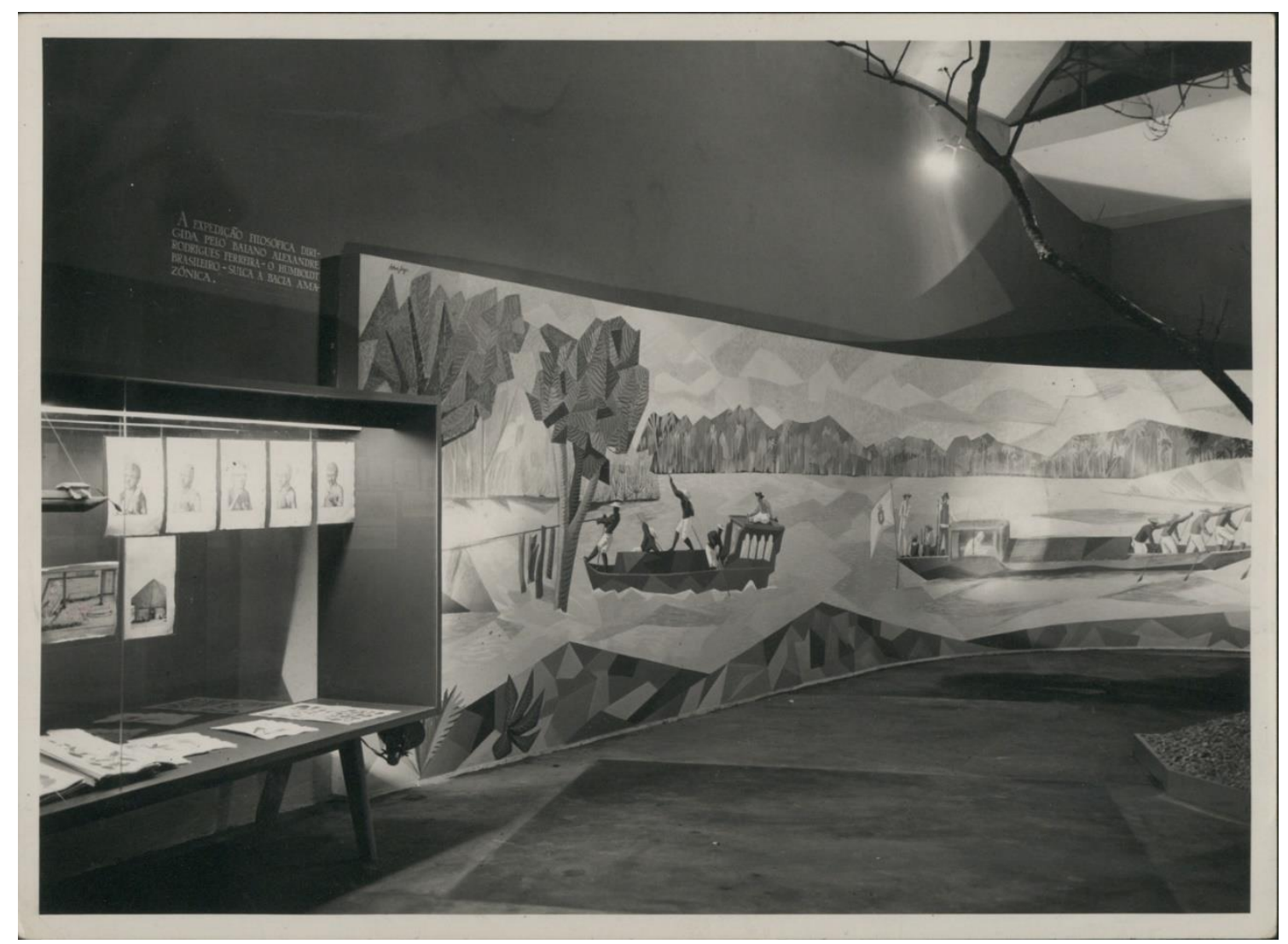

Imagem 20. Seção VI. Painel de Artur Jorge sobre a "Expedição Filosófica" de Alexandre Rodrigues Ferreira. São Paulo, 13 set. 1954. Fotógrafo: Bernardelli. BNP/ACPC E25/1509.

A seção é concluída com um conjunto de mapas de Silva Pontes e José Fernandes Portugal, "o maior hidrógrafo de seu tempo". Entre esses mapas, um do Atlântico e um do Índico, com direção de ventos e correntes de acordo com a época, são destacados como precursores dos mapas de navegação que depois se tornariam fundamentais. No texto da Introdução do catálogo, menciona-se que Fernandes Portugal tinha servido à Marinha portuguesa, tendo participado da Revolução Pernambucana de 1817 e morrido na prisão naquele mesmo ano. Além disso, abrese o caminho para o século XIX a partir de um painel com as missões científicas e artísticas do tempo de D. João VI, tempo do qual também se apresentam as moedas 
de ouro portuguesas até a independência do Brasil, encerrando a seção com uma legenda a referir-se ao "esplendor" da Corte Portuguesa proporcionado pelo ouro brasileiro.

A participação direta de Cortesão se encerra com o término da sexta seção, na parte em que as histórias paulista e brasileira são política e administrativamente partes da história portuguesa. As três seções finais, dedicadas à Independência, ao Império e à República, destacando a participação paulista, ficaram a cargo, segundo o que se indica no catálogo, a Mário Neme e Ernani Silva Bruno, com a colaboração de Hélio Damante, Agostinho da Silva e outros.

\section{Seção VII - São Paulo e a Independência do Brasil}

Em São Paulo e a Independência do Brasil, a sétima seção da exposição com dez vitrines e dezoito painéis, ${ }^{264}$ recuava cronologicamente, tratando de assuntos indicados na seção anterior, narrados a partir de outro ponto de vista, identificando como marco inicial o ano 1765, da restauração da independência paulista em relação à capitania do Rio de Janeiro. Do período, apresenta-se, de acordo com o texto introdutório do catálogo, a recuperação econômica da capitania, o desenvolvimento do comércio de gado e o início da cafeicultura, no começo dos Oitocentos. Também a partir de então criaram-se escolas, difundiu-se o ensino e reuniram-se as

condições materiais e espirituais suficientes para que alguns de seus homens mais esclarecidos - os Andradas, Vergueiro, Feijó interpretando o espírito de nativismo e de autonomia que remontava ao tempo das bandeiras, dessem a ela o papel de primeira grandeza na campanha da independência política do Brasil. ${ }^{265}$

$\mathrm{Na}$ zona de intersecção do recorte temporal entre essas duas partes da Exposição de História, os indicadores de autonomização do Brasil em relação a Portugal foram aprofundados, evidenciando a ênfase que o próprio nome da sétima seção fazia entender. Esses indicadores eram apresentados, por exemplo, por meio da literatura e das artes, dispostos de modo a demonstrar o "avanço dos brasileiros no campo das ideias". O painel de abertura da seção era dedicado a Aleijadinho,

\footnotetext{
${ }^{264}$ CORTESÃO, J. et al. Seção VII - São Paulo e a Independência do Brasil. In: [1954/1955], $26 \mathrm{p}$.

${ }^{265}$ CORTESÃO, J. et al. Introdução. In: Op. cit., [1954/1955], p. 17. Op. cit.,
} 
"figura de maior expressão da arte brasileira no período colonial" e fortemente celebrada desde a projeção do movimento modernista e a primeira vitrine continha exemplares de livros como Caramuru e O Uraguai. Nesse mesmo sentido, movimentos como a Inconfidência Mineira e personalidades como Tiradentes também têm dedicados um espaço, do qual constam esculturas - como um grupo escultórico produzido especialmente para a exposição por Quirino da Silva -, documentos autógrafos, retratos, entre outros.

Pelo que se indica, a seção foi dividida tendo por base dois períodos: o anterior e o posterior a 1808, ano da chegada da Família Real portuguesa ao Brasil e da transferência da sede da Corte para o Rio de Janeiro. Do primeiro momento, figuram por exemplo trajes militares da Legião de Voluntários e do Regimento de Cavalaria Miliciana reproduzidos em aquarelas de Wasth Rodrigues. Salienta-se no texto que os homens que São Paulo fornecia deveriam guarnecer as fronteiras do Sul nas guerras contra os espanhóis, sempre prontas para marcharem ao socorro de Viamão, Rio Pardo e Rio Grande de São Pedro. A Legião de Voluntários Reais ficou conhecida como Legião de São Paulo.

Dois mapas ilustram na seção a ocupação do território paulista. Um, de 1792, levantado a pedido do Bernardo José de Lorena, governador, e outro feito especialmente para a exposição pela equipe coordenada por Luís Saia. Nélson Nóbrega, pintor, fez a pedido da organização da exposição um painel com os elementos relevantes da economia paulista da época, como os muares de Sorocaba e os engenhos de açúcar, como o de água encontrado na Ilha de São Sebastião em fins do XVIII. Acompanham também reproduções de telas do Padre Jesuíno do Monte Carmelo, o manuscrito original de Pedro Taques e um exemplar da primeira edição de Frei Gaspar da Madre de Deus, além de documentos sobre as aulas régias elementos que buscaram dar conta da situação das letras e das artes na capitania no período.

Da chegada da Família Real, expôs-se o documento original que abriu os portos brasileiros ao comércio internacional em 1808. Os retratos de D. Maria I e de D. João VI, ambos do Museu Paulista, bem como um aspecto do Largo do Paço pintado pelos artistas da exposição inspirado no original de Debret, foram acompanhados por objetos emprestados pelo Museu Imperial de Petrópolis e por algumas das muito anunciadas aquarelas de Thomas Ender (1817), "remetidas da Áustria expressamente para a Exposição". Além disso, na esteira da instalação da 
Corte, fizeram parte da exposição menções e objetos referentes à missão artística francesa, à imprensa régia, à criação do Jardim Botânico, a Biblioteca Real e o Museu de Ciências Naturais.

O segundo segmento da seção apresentava o aumento da produção açucareira e a introdução da cafeicultura no vale do Paraíba, região apresentada pelas aquarelas originais de Thomas Ender e pelas reproduções a partir de Debret. Além disso, do quadro econômico do período era citada a Real Fábrica de Ferro de São João de Ipanema, nas cercanias de Sorocaba. Tal transformação era, de acordo com a narrativa da exposição, inserida no quadro dos reflexos das medidas da Corte instalada no Rio de Janeiro. Assim como no novo mapa executado pela equipe de Luís Saia a mostrar a expansão do povoamento paulista, ora na década de 1810 a 1819, pululam documentos textuais e iconográficos registrando a fundação de novas vilas, cidades e comarcas, muitos deles pertencentes a coleções particulares, entre elas as de Yan de Almeida Prado e Benedito Peretto.

O ano de 1810 mereceu da organização da exposição um painel especial: naquele ano, a cidade de São Paulo recebia uma filial do Banco do Brasil, erguia o chafariz do Piques e o obelisco da Memória. Também naquela data, o capitão de engenhos Rufino José Felizardo e Costa fazia levantar a primeira planta da cidade, exibida em fotografia ao lado de diversas vistas da cidade aquareladas também por Ender.

A finalização da seção, como não poderia deixar de ser, dizia respeito à própria Proclamação da Independência, apresentada por meio de retratos, gravuras e documentos manuscritos e impressos dispostos em quatro painéis e três vitrines. Inicialmente, um panorama da cidade de São Paulo, pintado pelos artistas da exposição a partir de uma aquarela de Pallière, da coleção de Yan de Almeida Prado, se fazia acompanhar de uma legenda introdutória ao assunto, comunicando o crescimento das tensões entre brasileiros e reinóis, a propaganda de ideias autonomistas e liberais, o retorno da Família Real e a intimação para o retorno de D. Pedro. Os "homens políticos da Independência" foram dispostos em um painel, com retratos originais cedidos pelo Museu Paulista e reproduções dos que se encontravam no acervo da mesma instituição. Documentos oficiais e correspondências ocuparam as vitrines: entre eles figuram a Representação da Junta Governativa de São Paulo, dirigida a D. Pedro em fins de 1821, pedindo-lhe que não 
atenda ao pedido de Lisboa para que retorne a Portugal. O documento dizia da possibilidade de derramamento de sangue no Brasil em caso da ausência do príncipe.

$\mathrm{Na}$ vitrine que encerrava documentos referentes aos eventos transcorridos entre junho e setembro de 1822, registrava-se na exposição uma fala de D. Pedro Ium trecho da primeira após a Proclamação, dirigida à Câmara de São Paulo - que atestava a relevância dos paulistas na campanha de autonomização do Brasil. Transcrita já no texto de introdução do catálogo, a fala designava a Província de São Paulo como o ponto em que a Independência havia acontecido, antes de qualquer outra parte. Ainda que se refira ao locus da Proclamação, no sítio histórico do Ipiranga, a interpretação da exposição conduz para o entendimento de que foi aquela terra que fez o Brasil independente. Dessa forma, as próprias palavras de D. Pedro eram mobilizadas para celebrar a história local, na exposição preocupada, em seu sentido amplo, em afirmar o papel paulista na construção da história nacional, seguindo a tendência inaugurada pelo guardião da história paulista, o Instituto Histórico e Geográfico de São Paulo, segundo o qual a história de São Paulo seria a própria história do Brasil. ${ }^{266}$

Hinos, objetos pertencentes a pessoas presentes na comitiva de D. Pedro, a Carta Régia de reconhecimento da Independência do Brasil, bem como uma reprodução de Independência ou Morte de Pedro Américo e um padrão da primeira bandeira imperial pertencentes ao Museu Paulista foram apresentados em um painel e uma vitrine. Uma liteira e dezesseis aquarelas de Pallière e Ender, encerravam a seção dando conta de cenas do cotidiano escravista, questão essa praticamente silenciada ao longo de toda a mostra.

\section{Seção VIII - São Paulo no Império}

Exibindo o Brasil monárquico, a oitava seção, São Paulo no Império, buscou dar ênfase, assim como na anterior, ao papel paulista na política, na economia e na vida social do período imperial. Com 21 painéis - o maior número da mostra - e catorze vitrines, a oitava seção era uma das maiores da exposição. ${ }^{267}$ Naquela época

\footnotetext{
${ }^{266}$ A esse respeito, ver FerreirA, A. C. Op. cit., 2002; SCHWARCZ, L. M. O espetáculo das raças: cientistas, instituições e questão racial no Brasil, 1870-1930. São Paulo: Companhia das Letras, 1993. ${ }^{267}$ CORTESÃO, J. et al. VIII Seção - São Paulo no Império. In: Op. cit., [1954/1955], $50 \mathrm{p}$.
} 
desenvolveram-se na região os principais recursos econômicos da região, assim como foi instalada a Academia de Direito (1828). De acordo com o texto introdutório do catálogo, sobre a vida política na província foi mencionada a oposição ao absolutismo de D. Pedro e também a ação do padre paulista Diogo Feijó durante o período das Regências.

O painel de abertura da seção e os dois seguintes, bem como as primeiras vitrines, foram dedicados ao Primeiro Reinado e às Regências, destacando personagens políticas, objetos da Família Real e documentos oficiais e representações pictóricas das cidades de São Paulo e Rio de Janeiro além de cenas como a da dissolução da Assembleia Legislativa em 1823. A Diogo Feijó, um painel com o seu retrato a óleo, cedido pelo Museu Paulista, era acompanhado de uma legenda a identificar algumas de suas iniciativas durante o período da regência documentadas em uma vitrine. Antes de apresentar um panorama da província paulista entre 1822 e 1840, dispunha-se um painel dedicado à Maioridade de D. Pedro II, com um retrato a óleo do monarca aos quinze anos cedido pelo Museu da Cúria Metropolitana de São Paulo. Em seguida, foram destacadas algumas iniciativas provinciais ao longo do Primeiro Reinado e das Regências, como a abertura de uma estrada entre Santos e Cubatão, o estabelecimento de colonos alemães em Santo Amaro e a instalação de uma fábrica a vapor em Santos. A Academia de Direito, instalada em 1828 sob a direção de José Arouche de Toledo Rendon, foi apresentada em um painel no qual os retratos de alguns dos primeiros professores, como Júlio Frank e Avelar Brotero, se salientavam. Ao lado do painel, uma vitrine era dedicada às realizações dos presidentes da província, notadamente Rafael Tobias de Aguiar.

Mapas, reproduções fotográficas e pinturas iam apresentando a cidade de então. Para expor a situação econômica da província durante aquele tempo, os painéis da seção mostravam "o aperfeiçoamento dos engenhos de açúcar", demonstrados por uma moenda de ferro, fabricada na fábrica de São João de Ipanema, do acervo do Museu Paulista, além do crescimento "notável" das lavouras de café, inicialmente no Vale do Paraíba - ora ilustradas com uma maquete da fazenda Pau d'Alho, de São José do Barreiro, executada pela equipe de Luís Saia.

Quanto às letras, às artes e ao ensino, relevava-se a criação da Academia de Direito, instituição que influenciaria bastante a vida política e intelectual de São Paulo e do Brasil. Além disso, o primeiro jornal impresso, O Farol Paulistano e os 
primeiros livros editados na cidade, a primeira Biblioteca Pública, o Gabinete Topográfico para o ensino de medições de terrenos e construção de estradas e pontes se faziam observar, assim como as aquarelas de Miguel Dutra, do Museu Paulista.

Do Segundo Reinado, diversos acontecimentos eram eleitos como marcantes, como a Revolução Liberal de 1842 e a Guerra do Paraguai, ambas com painéis e vitrines dedicados a elas. Segundo a legenda, a guerra declarada contra a República Paraguaia era uma reação aos "atos de hostilidade do ditador Solano Lopez", vencido pelas "tropas brasileiras" nas "batalhas memoráveis em Riachuelo, Avaí, Tuiuti, Curuzú, Humaitá", ocupando Assunção em 1869. Retratos dos chefes do Exército, mapas, documentos, reproduções fotográficas de pinturas e armas compunham o painel e as vitrines.

Quanto à questão da escravidão de africanos e afrodescendentes, aos quais pouco espaço se dedicou nas seções anteriores, foram apresentados na oitava seção "peças e documentos relativos às condições de vida e trabalho do escravo negro no Brasil". Entre eles, os diversos instrumentos de castigo e uma ampliação fotográfica de Negros no eito (1885), de Marc Ferrez, dividiam o espaço com os registros das "etapas da campanha abolicionista, em que São Paulo teve papel destacado, desde a atuação de Rui Barbosa, Luís Gama, Castro Alves e do jornal O Radical Paulistano, até a fundação do Centro Abolicionista, em 1882", de onde se projetaram novos líderes como José Bonifácio, o Moço e Antônio Bento. Figuravam na exposição numerosos documentos relativos à instituição da escravidão, desde contratos de venda, autos de inquéritos policiais contra escravizados a exemplares de jornais que se bateram contra o cativeiro e a fotocópia do original da Lei Áurea. Retratos de Luís Gama, Antônio Bento, José do Patrocínio e da Princesa Isabel também compunham a apresentação do assunto.

O movimento republicano, também para marcar a projeção paulista no quadro da história nacional, teve a sua narrativa aberta por um painel com ampliações fotográficas de retratos de lideranças republicanas paulistas. A legenda citava a criação do Partido Republicano no Rio de Janeiro em 1870 e a Convenção de Itu em abril de 1873. Segundo o texto introdutório, os ideais liberais em voga naquele tempo em muito tinham a ver com o programa republicano então apresentado. À Convenção, uma vitrine foi dedicada, apresentando documentos como os Livros de Atas e de Presença. 
Um painel tratava de apresentar um "plano econômico do país" no Segundo Reinado e mencionava especialmente o Barão de Mauá e as suas iniciativas. Caracterizado como "colonizador, banqueiro, financista, político", o barão era destacado sobretudo pela sua ação no campo da indústria, fundando empresas ferroviárias e de navegação, entre outras diversas, em várias regiões do país. Ao "progresso intelectual e artístico do país" durante o Segundo Reinado: um painel e uma vitrine fizeram menção a artistas e a obras literárias dos anos 1850-1880: Machado de Assis, Tobias Barreto, Aluísio Azevedo, Pedro Américo, Vítor Meireles, José de Alencar, entre outros.

No que dizia respeito a São Paulo, o Segundo Reinado foi lembrado especialmente pelas ferrovias e pela imigração europeia, quando "consolidam-se os fundamentos do progresso contemporâneo de São Paulo". A legenda que sintetiza o período destaca as transformações da capital da província "no seu aspecto urbano, tornando-se ao mesmo tempo importante centro artístico, científico e literário". Pelo que se indica, tal momento áureo da cidade de São Paulo, que também prenunciava o presente, explicava em seus termos as razões do progresso paulista. Desse mesmo período, na sequência, um painel apresentava uma galeria com governantes e bispos paulistas, mencionando ainda o incremento de um milhão de habitantes em um século, apesar do desmembramento da província do Paraná em 1853. Cinco mapas apresentavam a marcha do povoamento do território paulista em períodos de dez anos, executados pela equipe de Luís Saia.

Ainda nesse sentido, um painel aprofundava-se sobre a questão da "conquista do Oeste" do território paulista, dando especial relevo ao café e às ferrovias. Um mural de Di Cavalcanti (imagem 22) evocava então diversos aspectos de uma fazenda da época. As ferrovias Santos-Jundiaí, Paulista, Ituana, Sorocabana, Mogiana, São Paulo-Rio de Janeiro, Bragantina, do Bananal, além dos "esforços de alguns homens de São Paulo no sentido de atrair para a sua província trabalhadores europeus, visando a substituição do trabalho servil pelo trabalho livre" corporificavam o inconteste progresso econômico provincial. Todo esse cenário, amalgamando escravidão negra e imigração europeia, começos da industrialização e poderes político e eclesiástico foram capturados pela imagem apresentada a seguir (imagem 21): 


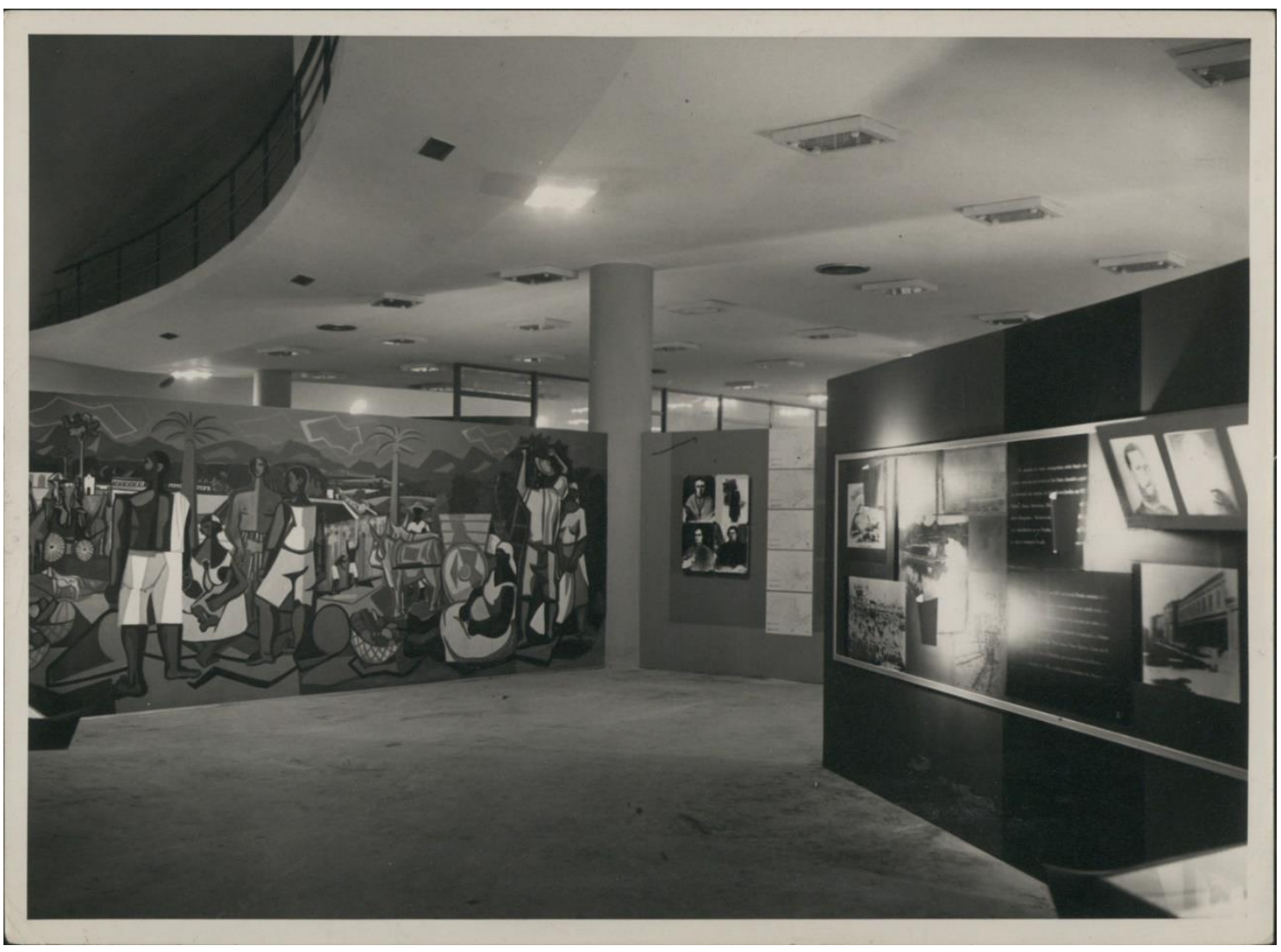

Imagem 21. Detalhe da VIII Seção - São Paulo no Império. Ao fundo, painel de Di Cavalcanti sobre a lavoura cafeeira. São Paulo, 13 set. 1954. Fotógrafo: Bernardelli. BNP/ACPC E25/1510.

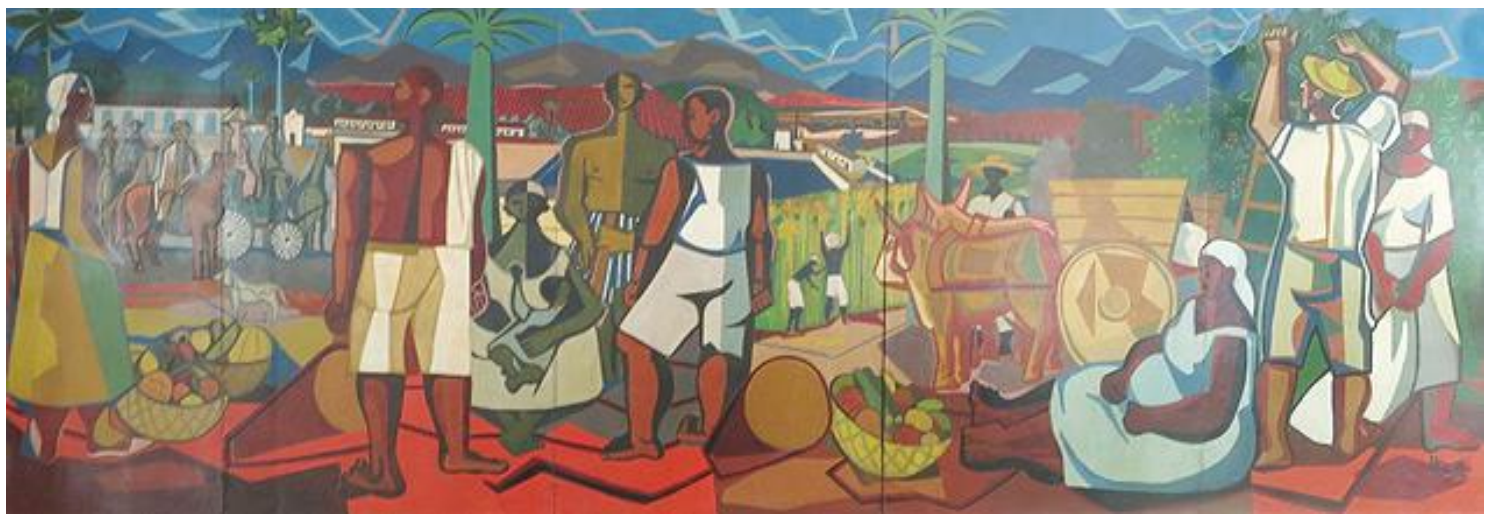

Imagem 22. Painel de Di Cavalcanti sobre a lavoura cafeeira. In: MARTÍ, S. Mural esquecido de 1954 é descoberto atrás de uma parede falsa na Oca. Folha de S. Paulo, São Paulo, 13 jul. 2015. (Imagem da Coleção de Arte da Cidade/ CCSP).

Para concluir a seção, o tema do ensino, das letras e das artes foi novamente apresentado, acompanhado dessa vez por um panorama do desenvolvimento urbano da capital. No período fundaram-se escolas, surgiram os primeiros jornais diários, tiveram incremento as atividades literárias e artísticas, bem como os estudos jurídicos. Como representantes dessa fase, destacam-se o historiador Varnhagen, o compositor Carlos Gomes e o pintor Almeida Júnior. 


\section{Seção IX - São Paulo na República}

A última seção da exposição, São Paulo na República, teve como ponto de partida o ano de 1889. De acordo com o texto introdutório do catálogo e com a legenda impressa no painel de abertura, o advento republicano foi considerado como "etapa necessária do desenvolvimento político, econômico e social do país, desde a sua independência". Ainda nesse sentido, a mudança de regime políticoadministrativo seguia a mesma tendência que introduzia novas modalidades de "produção de riqueza", a partir da mecanização e da introdução de imigrantes "dotados de tradição industrial", vinculando tacitamente a monarquia ao escravismo. A ampliação do comércio com o exterior e o crescimento da urbanização, complementando o quadro, teriam impacto sobre as condições de vida e de trabalho. A seção saudaria ainda a descentralização e também as "novas oportunidades" abertas à agricultura, à indústria, ao comércio e aos profissionais.

Segundo o texto de introdução sobre a seção, os propagandistas da república, especialmente os paulistas, se aproveitaram da crise final da monarquia para "forçar os acontecimentos no sentido da instauração do regime por que se bateu". Após a proclamação, caberia essencialmente aos republicanos de São Paulo "a maior soma de responsabilidade na obra de estruturação e consolidação do regime, bem como na orientação política e administrativa do país". Ao demarcar o ponto de vista estruturante da seção final da exposição, é notável o esforço para justificar o domínio das oligarquias paulistas durante os primeiros tempos da República, baseando-se na perspectiva segundo a qual São Paulo teria essa "responsabilidade" por conta da proeminência que a província e então estado tinha alcançado em relação às outras unidades da federação constituída. Esse crescimento vigoroso estaria expresso na cafeicultura, na indústria, nas ferrovias e rodovias, no ensino.

Em suma, rememoradas as ações dos "estadistas de São Paulo à frente do governo da República", a exposição mostraria "que os paulistas desempenharam satisfatoriamente essa alta missão e que, dentro das limitações impostas por fatores adversos, contribuíram de maneira decisiva para o progresso do Brasil". Nesse sentido, encerrando a exposição, o ato final permitiria ao visitante que percorresse os sete mil metros quadrados da Oca uma visão de conjunto da história de São Paulo como a base que teria permitido a construção do país, vinculando símbolos de grandeza do passado e do presente como fragmentos de um mesmo percurso. 
A nona seção, com as suas onze vitrines e 15 painéis, sintetizava sobretudo, a imagem que São Paulo e as suas elites faziam de si e de sua história, celebrada com relevo no interior do Palácio de Exposições do Parque Ibirapuera. ${ }^{268}$ A seção foi aberta com os "episódios" e "figuras de maior realce na proclamação da República", apresentando para tanto documentos, mapas e gravuras relacionados aos primeiros governos, de Deodoro a Rodrigues Alves. Prudente de Morais era louvado como aquele que apesar de grave crise financeira, conseguira "pacificar o país" e "consolidar a República". Ao também paulista Campos Sales, atribuía-se a normalização da situação econômica, favorecendo a entrada de capital estrangeiro, investido em portos, usinas elétricas e serviços públicos. Rodrigues Alves, por seu turno, foi lembrado pelas reformas administrativas, pelo estímulo às atividades produtoras, pela remodelação da capital do país - quando Osvaldo Cruz realizou a sua "obra notável de saneamento" e criou o Instituto de Patologia Experimental de Manguinhos.

Sobre a vida intelectual no período, a seção deu espaço às vitórias diplomáticas do Barão do Rio Branco e às obras de historiadores, ensaístas, sociólogos e poetas que marcaram as letras e o pensamento brasileiro, como Nina Rodrigues, Euclides da Cunha, Clovis Bevilacqua, Capistrano de Abreu, Oliveira Lima, Silvio Romero, Olavo Bilac, Graça Aranha, Lima Barreto, entre outros.

Diferentemente das questões apresentadas como nacionais, as que se relacionavam diretamente a São Paulo avançaram na exposição até a década de 1930. Segundo o texto introdutório do catálogo, a "autonomia administrativa, decorrente da nova estrutura política do país" teria favorecido o desenvolvimento econômico paulista. $\mathrm{O}$ federalismo era assim vivamente celebrado, atribuindo-se a ele a razão do sucesso econômico e da possibilidade de o estado desfrutar de suas glórias. Seguiam-se os números que atestavam o crescimento da cafeicultura, o lançamento das bases da policultura, bem como o enriquecimento do parque industrial. Tal crescimento econômico era acompanhado pelo crescimento demográfico - incrementado pela persistência da onda imigratória - levando a população do estado de 1.400 .000 habitantes em 1889 para mais de sete milhões em 1930.

${ }^{268}$ CORTESÃo, J. et al. Seção IX - São Paulo na República. In: Op. cit., [1954/1955], $28 \mathrm{p}$. 
Novamente o assunto da expansão para o oeste do estado, impulsionada pela cafeicultura e pela ampliação das redes ferroviária e rodoviária eram apresentados. Além da menção à criação de 129 novos municípios, outros elementos que atestavam o crescimento do estado eram trazidos à cena, como a construção da hidrelétrica de Parnaíba, inaugurada em 1901 e "considerada na época uma das maiores do mundo"; a criação da Escola Agrícola Prática de Piracicaba por Luís Vicente de Sousa Queirós; a exploração dos "sertões marginais" do rio Paraná e seus afluentes Tietê, Aguapeí e do Peixe, em 1905, por iniciativa do Secretário da Agricultura Carlos Botelho; a restauração do Caminho do Mar (1913), dirigida por Rudge Ramos e que seria o "ponto de partida para o surto rodoviário paulista".

Um mural da pintora Estrela de Faria representava o movimento imigratório e outro de Arnaldo Pedroso d'Horta simbolizava o progresso industrial do estado. Gravuras e documentos tratavam dos assuntos do café e da rede ferroviária, mencionando inclusive o Convênio de Taubaté, que em 1906 firmou entre Minas, Rio de Janeiro e São Paulo uma política de defesa do produto.

Alberto Santos Dumont e as suas experiências sobre o avião foram apresentados em um painel, como que abrindo o caminho para as atividades de cientistas e educadores paulistas, que "concorreram para a criação de melhores condições de higiene, de saúde pública e de educação, através da reforma do Serviço Sanitário e da instalação de diversos hospitais e institutos de pesquisa (...)". Intelectuais e artistas como Amadeu Amaral, Vicente de Carvalho, Ramos de Azevedo, Monteiro Lobato figuravam então no primeiro painel que apresentava o panorama das letras e das artes no período, encerrados por outro dedicado à educação em todos os níveis e aos "modernos": Paulo Prado e Paulística, Alcântara Machado e Laranja da China, e Mário de Andrade e Losango Cáqui foram destacados. A legenda de abertura do segmento mencionava a Semana de Arte Moderna de 1922 como de grande alcance na renovação artística e literária do Brasil.

Caminhando para o fim do percurso da exposição, as transformações da cidade foram expostas por meio de fotografias ampliadas de lugares que não mais existiam ou por outros que totalmente transfigurados. Nesse aspecto, apresentava-se uma série de mapas levantados especialmente para a exposição, "mostrando com todo o rigor científico a marcha da urbanização da capital paulista" de século em século, de 1554 a 1954. Antigas sesmarias tornaram-se sítios e chácaras, por fim transformados em lotes, ruas, praças públicas. 
Antes da série de mapas, no entanto, dois painéis e uma vitrine eram dedicados a um episódio então recente da história de São Paulo: a chamada Revolução Constitucionalista de 1932. A legenda que comunicava o episódio que havia mobilizado corações e mentes paulistas, enquadrava o acontecimento à narrativa ora apresentada da "história de São Paulo no quadro da história do Brasil". O texto mencionava então "três ciclos de conquistas": o da terra, o do ouro e o que dava "legitimidade ao chão, que desbravaram as bandeiras e as monções, (...), que engendraram as minerações e as lavras, o da conquista da lei", representado pela "Guerra Cívica do 9 de julho de 1932", ciclo que embora breve no tempo era "longo no sentido". Aludindo a uma fusão dos paulistas "num único ser humano" acima de todas as diferenças, a exposição também fundia nos objetos - como a bandeira paulista hasteada pelos estudantes de Direito na Academia em 1932, pertencente a Júlio de Mesquita Filho, as armas, distintivos, fotografias e um mapa das frentes de combate pertencente ao poeta, presidente da CIVCCSP e ex-combatente Guilherme de Almeida - o sentido de toda a exposição. Sobre Getúlio Vargas, o absoluto silêncio.

O último painel da exposição comunicava, por meio de um texto-síntese, o sentido da mostra que ali se encerrava. Ao visitante, o encerramento da "didática" como se apresentava na imprensa local - apresentação da história de São Paulo no quadro da história do Brasil (e de Portugal):

Com a herança das culturas europeias transplantadas pela audácia dos navegantes portugueses para as terras da América; com o conhecimento dos caminhos e das coisas da terra ensinados pelos índios; com o espírito do cristianismo trazido pelos apóstolos e os missionários; com a tenacidade e a bravura dos bandeirantes descobrindo e povoando territórios; com o humilde e formidável trabalho dos negros e mestiços, com o sentimento de nativismo e os impulsos patrióticos que levaram à Independência do Brasil; com o esforço dos soldados nos campos de batalha; com a experiências dos imigrantes nas labutas do campo e da cidade construiu-se a grandeza de São Paulo. ${ }^{269}$

Como se fossem créditos, qualificando a forma como cada grupo social teria contribuído para a "grandeza de São Paulo", o painel final parecia dessa forma querer causar no visitante - especialmente se ele fosse paulista e representasse de alguma forma a herança de algum dos grupos mencionados - o sentimento de pertença aos signos de identidade que ali se expunham materialmente: a exposição

\footnotetext{
${ }^{269}$ Com pequenas diferenças que não alteram o sentido, o texto foi transcrito tanto na introdução do catálogo quanto na descrição pormenorizada da exposição. O painel que encerrava a seção e a exposição era o $135^{\circ}$.
} 
era assim um patrimônio. Além disso, as frases gravadas no painel sintetizavam ideias presentes em cada uma das seções, elegendo os que haviam tornado possível aquela narrativa, não indicando, porém, outras alternativas para caracterizar o percurso. Encerrando essa longa visita, vejamos alguns dos indicativos da recepção da exposição e as suas permanências nos museus paulistas. A partir disso, poderemos perceber, considerando especialmente o papel central de Jaime Cortesão na exposição, e abordando os poucos vestígios da apreensão do público, a forma como a exposição e a sua narrativa interagiram com a cidade, a sociedade e a produção do conhecimento.

\section{Didática, cívica, científica - e inédita: a Exposição de História de São Paulo no quadro da produção do conhecimento}

A Exposição de História foi inaugurada solenemente em 13 de setembro de 1954 pelo ministro português dos Negócios Estrangeiros Paulo Cunha, que cortou a fita de abertura. O ministro estava no país em visita oficial, ocorrida tempos depois de ter sido celebrada em Lisboa, com a presença de representantes do poder executivo da cidade e do estado de São Paulo, o transcurso do quarto centenário. Na ocasião, estiveram ainda presentes o embaixador de Portugal no Brasil, Miguel Paile ${ }^{270}$, além de Júlio de Mesquita Filho, Francisco Matarazzo Sobrinho e os membros do Segundo Colóquio de Estudos Luso-Brasileiros, entre tantos outros convidados. De maneira "inédita e moderna", os quatro séculos de história paulista - e de história do Brasil - eram contados, conforme registrava no dia seguinte o matutino de Mesquita Filho. Jaime Cortesão, organizador da exposição, e Guilherme de Almeida, então presidente da Comissão do IV Centenário, discursaram em seguida.

No discurso do professor português, não faltaram agradecimentos ao expresidente da Comissão, Matarazzo, a quem segundo ele caberiam os méritos da iniciativa de realizar uma exposição de história, bem como tomar a decisão "muito arriscada" de convidar Cortesão para executá-la. A Guilherme de Almeida agradecera o mesmo estímulo, bem como aos governos estrangeiros que se

\footnotetext{
${ }^{270}$ Miguel Paile foi quem transcreveu e remeteu a programação e o convite para Cortesão do Congresso Internacional de História que seria realizado em São Paulo, organizado pelos professores da Universidade de São Paulo.
} 
dispuseram a contribuir com a cedência de documentos e obras. Deferência maior coube ao governo português, a quem se deveu a exposição de obras de arte e importantes documentos "referentes ao mais remoto passado da história brasileira". A Paulo Cunha e a Miguel Paile, coube o agradecimento pela resolução de questões inerentes aos empréstimos. Além disso, Cortesão agradecia aos colaboradores, artistas e técnicos, mencionando especialmente os nomes dos que planejaram o roteiro e a montagem da exposição: Mário Neme, Ernani Silva Bruno, Manuel Lapa.

A preocupação "máxima" dos organizadores da mostra, segundo Jaime Cortesão, teria sido a "ordenação lógica e científica", sem descuidar "da documentação histórica nem da distribuição das várias seções, que vão desde a época do descobrimento aos nossos dias". A edição d'O Estado de S. Paulo da data em que a exposição seria aberta ao público, no fim da tarde, registrava além disso um trecho da fala de Cortesão. Nela, o organizador metaforizava a exposição em uma viagem marítima: "Chegados que fordes à 1 . $^{\text {a }}$ seção, tantas são as evocações marítimas, que vos surpreendereis, como se estivésseis a bordo. Oxalá a viagem não vos fatigue e seja grata. E permiti, agora, que eu me arvore em piloto de largada". O discurso do poeta Guilherme de Almeida, presidente da CIVCCSP, construiu-se sob o signo da cruz, símbolo constante dos primórdios da nação portuguesa à história da colonização da terra sul-americana. ${ }^{271}$

Dois meses após a abertura, uma reportagem no mesmo periódico que acompanhou todo o desenvolvimento da exposição, divulgando textos sobre as seções, apresentando algumas das obras e peças expostas e demonstrando sua relevância, comentava do "vivo interesse" que a mostra vinha despertando na população. Em um edifício de "ousada arquitetura", a exibição que ocupava os dois pisos do pavilhão era, como constantemente, marcada pelo seu ineditismo no país: não se tratava de uma simples mostra ou exposição de objetos - era "um certame, por assim dizer, vivo, em que se casam arte e história para oferecer uma visão de conjunto dos quatro séculos e vida de São Paulo e de seu papel na história pátria".

A reportagem, em tom de divulgação da mostra, a identifica como "ao mesmo tempo didática e científica", estando ao alcance do "grande público" como dos "estudiosos, que ali encontram material valiosíssimo, muitas vezes inédito, que

\footnotetext{
${ }^{271}$ Instalada ontem a Exposição de 4 Séculos da História Paulista. In: O Estado de S. Paulo, São Paulo, 14 set. 1954, p. 12.
} 
desvenda curiosas perspectivas no campo da historiografia". O didatismo, por seu turno, residia no fato da exposição proporcionar aos estudantes, em especial, "uma proveitosa lição de história pátria". Infelizmente não assinado, o texto reportagem/resenha/divulgação publicado no jornal para o qual Cortesão e diversos outros intelectuais de sua rede escreviam, citava ainda que milhares de pessoas acorriam ao Palácio de Exposições diariamente, não escondendo o seu entusiasmo. Ademais, o circuito "cultural e cívico" exposto dispunha de monitores, "cuidadosamente selecionados" para acompanhar os visitantes ao longo das nove seções. ${ }^{272}$

Na seção "Colaboração dos Leitores", porém, o Sr. Francisco Machado de Campos - apenas o nome identificado - escreveu ao jornal uma carta que foi publicada com a chamada Uma falha da Exposição do Centenário. O leitor d'OESP começava por destacar a grandiosidade do Ibirapuera, de seu ponto de vista pensada para uma cidade bem maior do que a que existia, e para a realização de "futuras e exuberantes mostras de nosso desenvolvimento econômico e cultural". O contrário, segundo o leitor, se via na realização de outras obras da cidade empreendidas pelo poder público, salientando ainda a eficiência da iniciativa privada. Campos, que se autodenomina "turista na história" comparou então o que leu no Guia para o Visitante e o que viu exposto: se no folheto indicavam uma homenagem "aos homens que construíram a grandeza de nossa Pátria", da mostra chamou a atenção a menção "desde o Infante D. Henrique, até Fernando Lemos, autor do painel decorativo do hall da Exposição", sucedendo navegadores, fundadores, colonizadores, bandeirantes na sua "faina de expansão de conquista de terras e riquezas", homens da Independência, da abolição da escravidão, entre tantos outros. No entanto, o leitor assinalou que apesar de todas as menções ao desenvolvimento científico e educacional, bem como aos que foram entusiastas da área, havia falhado a exposição ao não registrar "a criação de nosso instituto máximo de cultura que é a Universidade de São Paulo, a matriz das universidades brasileiras, concebida pelo estadista de escol que foi Armando de Salles Oliveira".

A redação do jornal deu em seguida o seu parecer sobre a correspondência, concordando no essencial com o leitor, apontando para o fato da própria folha não

\footnotetext{
${ }^{272}$ Continua despertando vivo interesse a Exposição de História. In: O Estado de S. Paulo, São Paulo, 30 nov. 1954, p. 9 . O texto traz a informação sobre o funcionamento da exposição, aberta ao público da terça-feira ao sábado das $14 \mathrm{~h} 30$ às $22 \mathrm{~h} 30 \mathrm{e}$ aos domingos das $12 \mathrm{~h}$ às $22 \mathrm{~h} 30$.
} 
ter poupado elogios à realização da exposição e de ter discordado somente do seu local de realização, reafirmando sua posição contrária à construção dos pavilhões no Parque Ibirapuera, como já vimos aqui. Do ponto de vista da redação, a crítica de Campos foi feliz, reiterando que a criação da Universidade era "um dos acontecimentos de maior relevo da nossa história, marcando o início de uma nova fase da evolução paulista". Complementando o que o missivista disse, a redação do matutino ainda afirmou que diversos acontecimentos e personalidades que "de modo algum deviam figurar num certamente daquela envergadura" foram acentuados, em detrimento do silêncio que pairou sobre Armando de Salles Oliveira e Universidade, iniciativa que, segundo a redação, ampliava as perspectivas políticas e econômicas do estado. ${ }^{273}$

Tal crítica pousava mais sobre os organizadores das últimas seções do que sobre Cortesão. Apesar disso, não é menos importante trata-la aqui, sobretudo em vista de outras considerações feitas por outros que discordaram dos critérios de organização. Por mais que Campos não escrevesse literalmente, de suas menções ao Infante D. Henrique a Fernando Lemos, pode-se subentender o excesso de relevo às personalidades portuguesas na exposição que apresentaria os que fizeram a grandeza de São Paulo - e que naturalmente, de acordo com o seu raciocínio, seriam paulistas. O relevo dado a tantos acontecimentos e pessoas que tanto do ponto de vista do leitor quanto da redação do jornal seriam ainda mais desnecessários em face do silenciamento a respeito da criação da Universidade de São Paulo. A instalação da instituição em 1934, ainda que reunindo também instituições preexistentes, pelo governador Armando de Salles Oliveira, na esteira da derrota de 1932, representava - como também pode se ler nas entrelinhas da opinião do diário - um novo início para as áreas da política, da economia, da cultura. Retomando algumas das questões que observamos sobre a cidade de São Paulo anteriormente, tanto os intelectuais da Universidade quanto o próprio $O$ Estado de $S$. Paulo podem ser vistos como parte de um mesmo processo de hegemonização cultural paulista, que nos tempos do quarto centenário da "metrópole bandeirante" se consolidava. ${ }^{274}$ Vale lembrar, ainda, que

\footnotetext{
${ }^{273}$ Colaboração dos leitores. Uma falha na exposição do centenário. In: $O$ Estado de S. Paulo, São Paulo, 5 dez. 1954, p. 6.

${ }^{274}$ A esse respeito, cito especialmente os trabalhos de MiCELI (2001); PONTES (1998); RODRIGUES (2011); CARDOSO, I. A. R. A universidade da comunhão paulista: o projeto de criação da Universidade de São Paulo. São Paulo: Cortez/Editores Associados, 1982.
} 
os organizadores das últimas seções eram vindos dos círculos "tradicionais" da produção do conhecimento histórico, como a Academia de Direito e o IHGSP.

Em março de 1955, quando a exposição se encerraria, uma série de textos assinada por Cortesão apresentava aos leitores o Plano Geral, as suas seções (da primeira à sexta) e o Balanço Final da mostra. O primeiro dos textos já se abria citando os "louvores da imprensa, de entidades científicas e de particulares", que não tiveram reservas em congratular a organização da exposição: isso para contrapor-se às "vozes discordantes", que eram postas em segundo plano diante de instituições "da mais alta categoria", como a Academia Brasileira de Letras, o IHGB e o IHGSP. Situandoas em dois polos opostos, Cortesão condensou as críticas em torno de dois exemplos: o de um historiador que protestou contra as figurações decorativas, defendendo uma apresentação limitada ao aspecto "científico"; e "outros" que entenderam que à exposição faltavam quadros "genuinamente paulistas", especialmente em comparação à "parte portuguesa".

Diante de tais críticas, Cortesão registra na coluna que não esperava unanimidade, considerando que "divergências fundamentais" se digladiavam sobre a própria interpretação da história. De seu ponto de vista, no entanto, teriam sido injustas acusações de ter se ocupado "com particular carinho" da "parte portuguesa" em relação à paulista. Em desagravo, o desmentido às insinuações seria a preparação e o lançamento de A fundação de São Paulo - Capital geográfica do Brasil, na obra, à luz de novos documentos e "novos métodos de interpretação", resolvia-se o problema da fundação. Produzido nas horas de descanso do processo de organização da exposição, o livro era a sua "contribuição pessoal às comemorações paulistas". O autor destacou ainda as publicações em curso de Alexandre de Gusmão e o Tratado de Madrid (1750) e os quarto e quinto volumes da Coleção De Angelis, além da Pauliceae Lusitana Monumenta Historica, que trariam consigo uma infinidade de documentos fundamentais para a historiografia paulista. Esses seriam, nas suas palavras, os escudos a protege-lo da "injúria", lembrando de todos os percalços para a execução de trabalho tão vultoso com recursos limitados e em pouco espaço de tempo.

O autor ainda lembrava aos leitores - especialmente aos seus críticos - que se tratava de uma exposição de acordo com os "conceitos contemporâneos da História, muito avessos da narrativa anedótica e episódica (...)", lembrando para tanto o papel dos "ilustres escritores e historiadores paulistas" Mário Neme, Hélio Damante e 
Ernani Silva Bruno, autor da "mais notável das obras sobre a história de São Paulo", citando História e Tradições da Cidade de São Paulo, publicada sob o selo oficial da Comissão organizadora dos festejos. Sobrelevando os mapas, Cortesão reitera o ineditismo do que foi exposto, mencionando a intenção de publicar o catálogo, capaz de dar a dimensão da realização. ${ }^{275}$

No Balanço Final, o autor ainda comentou sobre as críticas, entre elas a que portava sobre a ausência de uma "profecia" de Anchieta: de caráter "lógico" e "científico", não cabia à exposição tratar de assunto sobre o qual não havia documentos. Considerando as seções finais, Cortesão reitera o elogio a Neme e a Bruno, bem como a Damante, ressaltando o painel final em que se davam os "créditos" aos que haviam concorrido para a formação paulista. Lembrou ainda o organizador o efetivo painel final da mostra, dedicado a 1932, produzido com a participação direta de Guilherme de Almeida, o presidente da comissão, poeta e excombatente. Encerra o seu texto relembrando os esforços necessários à execução da exposição, montada em quatro meses, abrindo mão de diversos documentos por falta de espaço. Do crítico literário Valdemar Cavalcanti, Cortesão cita os seus elogios à execução da mostra, conclamando para que ela se torne permanente, mesmo que sem algumas de suas peças, cedidas por outras instituições: seria inconcebível que "uma obra de tamanho significado e alcance fosse de uma hora para outra fechada e dissolvida, como se se tratasse de uma simples barraca de um parque de diversões". ${ }^{276}$

Além dos títulos citados por Cortesão como demonstrativos de sua preocupação com a historiografia paulista, trazendo à discussão não apenas novos documentos como também novas interpretações sobre a fundação e a colonização da região vicentina, são vivamente presentes no percurso montado na Oca os conceitos e ideias escritos em suas obras de história, desde $A$ expedição de Pedro Álvares Cabral e o descobrimento do Brasil (1922) à História do Brasil nos Velhos Mapas (1965/1971), que seria lançada ainda anos depois da exposição. Além disso, da terceira à sexta seção condensa-se a elaboração presente em A fundação de São Paulo, Capital geográfica do Brasil (1955) e no posterior Raposo Tavares e a formação territorial

\footnotetext{
${ }^{275}$ CORTESÃo, J. A Exposição Histórica de São Paulo, I. O Plano Geral. In: O Estado de S. Paulo, São Paulo, 13 mar. 1955, p. 9.

${ }^{276}$ CORTESÃO, J. A Exposição Histórica de São Paulo, conclusão. Balanço Final. In: O Estado de $S$. Paulo, São Paulo, 3 abr. 1955, p. 7. De fato, a exposição foi remodelada em novembro de 1955, quando foram devolvidas peças pertencentes a outros estados. Em julho de 1956 foi reaberta, sem alteração do plano original de seções. Em nota n'OESP (9 jan. 1957, p. 10), é possível identificar que a exposição era aberta aos sábados, domingos e feriados, contando réplicas dos originais já devolvidos.
} 
do Brasil (1958), bem como Alexandre de Gusmão e o Tratado de Madri (1949 em diante) e os documentos dos Manuscritos da Coleção De Angelis. Ao visitante que não conhecesse os trabalhos do autor, no entanto, as referências talvez se detivessem sobre os exemplares de Alexandre de Gusmão dispostos na sexta seção.

Ressaltada pelos seus caráteres cívico, didático e científico, a exposição demonstra, a despeito da mencionada convergência entre Cortesão e os seus colaboradores diretos, uma ruptura entre os dois blocos: o primeiro, da primeira à sexta seção e o segundo, da sétima à nona. Se no primeiro bloco predominou a perspectiva de produção histórica de Cortesão, marcada substancialmente pela cartografia como fonte privilegiada, dividindo espaço com as artes visuais - ainda que a própria cartografia se aproxime dessa categoria -, no segundo bloco houve um predomínio de uma narrativa baseada na história "político-administrativa", sustentada não em temas-chave como nas seções anteriores e sim nos sistemas de governo e movimentos políticos. Embora perpassando assuntos do cotidiano, o segundo bloco pendia mais para o "cívico" do que para o "científico" do primeiro, ainda que se reconheçam elementos que assemelhem o conjunto da exposição.

Ernani Silva Bruno, egresso das cadeiras da Academia de Direito, publicou pela editora de José Olympio e com o selo do Serviço de Comemorações Culturais da CIVCCSP - os três volumes da sua História e Tradições da Cidade de São Paulo, obra prefaciada por seu amigo Gilberto Freyre. Dividindo a cidade em três tempos, o do "Arraial de Sertanistas" (1554-1828), o do "Burgo de Estudantes" (1828-1872) e por fim o da "Metrópole do Café" (1872-1954), o historiador registrava também um ponto de vista eminentemente paulista, corporificando a história de São Paulo em uma trajetória coerente e predestinada. ${ }^{277}$ Tais concepções o autor levou para as seções que ajudou a elaborar. Quando das comemorações do centenário de nascimento de Cortesão, Bruno homenageou o historiador português fazendo referências aos tempos da Exposição de História. Chamado de "luso-paulista", Cortesão foi lembrado como um "ilustre historiador", "cordial" e "brincalhão", que trazia de forma insuspeita em sua bagagem um "passado de lutas políticas e de aventuras guerreiras", além de suas atividades literárias, sobretudo na poesia e no teatro. Ernani Silva Bruno disse que, apesar de sabido, em nenhum momento

\footnotetext{
${ }^{277}$ Sobre essa obra, ver Lofego, S. L. História e Tradições da Cidade de São Paulo: Memória de uma Metrópole. Dissertação (Mestrado em História), Faculdade de Ciências e Letras, Universidade Estadual Paulista, Assis, 1996.
} 
Cortesão mencionou as suas histórias de militante republicano, de deputado, de combatente na Primeira Guerra. Para Bruno, o período de Cortesão no Brasil e o prosseguimento dos seus estudos fizeram dele "uma das mais notáveis figuras da historiografia luso-brasileira". ${ }^{278}$

A Francisco Matarazzo Sobrinho e a Guilherme de Almeida, bem como a seus colaboradores na realização da exposição, Jaime Cortesão oferece $A$ fundação de São Paulo, capital geográfica do Brasil, livro publicado em 1955 pela Livros de Portugal, editora carioca de seu amigo e compatriota Antonio Pedro Rodrigues. No prefácio da obra, Cortesão justifica o título dado a sua obra, resultante das pesquisas especificas sobre a história paulista feitas para a execução do plano da exposição. Reiterando a ideia de que a fundação da cidade de São Paulo foi um "ato fluido no tempo e múltiplo na ação", um processo decorrido entre 1532 e 1560, o autor recusa a simplificação em torno de uma data, justificável apenas para efeitos comemorativos. Parte significativa do texto contido no prefácio foi extraída de uma conferência proferida na capital portuguesa enquanto estava trabalhando para a exposição, em 26 de janeiro de 1954, na sede da Sociedade de Geografia de Lisboa. Discorre Cortesão sobre a tese de que Martim Afonso de Sousa e Manuel da Nóbrega são os agentes do referido processo, fundando não apenas uma cidade, mas implicitamente um "largo plano de expansão geográfica". ${ }^{279}$

O prefácio não se reservou apenas a discutir as bases interpretativas do processo histórico da fundação de São Paulo: grande espaço foi dedicado para responder às vozes daqueles que discordaram dos critérios da exposição. Aureliano Leite $^{280}$, historiador que constava como membro consultivo da mostra e o

\footnotetext{
${ }^{278}$ BRUNO, E. S. O centenário de Jaime Cortesão, luso-paulista. In: Comunidades de Língua Portuguesa, Revista Semestral de Cultura. Ed. esp., São Paulo, n. 5, 1985, p. 60-61. Bruno menciona Manuel Lapa, Fernando Lemos e Artur Jorge, portugueses e Tarsila do Amaral, Di Cavalcanti, Clóvis Graciano e Aldemir Martins. Lembra que muitos dos painéis haviam sido preservados e decoravam então a sede da Prefeitura de São Paulo. Além disso, o historiador relevou os papéis de Mário Neme e Hélio Damante, Yan de Almeida Prado, Darcy Ribeiro, Luís Saia e Wasth Rodrigues.

${ }^{279}$ CORTESÃO, J. A fundação de São Paulo: Capital geográfica do Brasil. Rio de Janeiro: Livros de Portugal, 1955 , p. 13.

${ }^{280}$ De acordo com Nanci Leonzo, Aureliano Leite, historiador e político, quando participou da consultoria técnica da exposição, reclamou não se fazer ouvir em suas sugestões e acabou abandonando os trabalhos. Além da solidariedade de alguns, Leite tinha estreitas e privilegiadas relações com o governo português, chegando a ser orador um banquete de despedida para o seu representante oficial. $\mathrm{Na}$ ocasião, aproveitou para tecer suas críticas ao trabalho de Cortesão, que rapidamente ganharam a imprensa e foram respondidas por Mário Neme. Leite reclamava a ausência ou a falta de destaque a personalidades como Anchieta e Amador Bueno. O antigo parlamentar por São Paulo e admirador de Salazar - comparava-o ao Marquês de Pombal - já havia defendido os interesses colonialistas portugueses na tribuna da Câmara dos Deputados. Nunca tinha se
} 
desembargador Soares de Melo receberam de Cortesão as respostas aos seus questionamentos, semelhantes aos que o professor tinha respondido n'OESP. Lembrou o autor que o principal objetivo da exposição foi o de apresentar, sim, a história paulista, mas dentro de um quadro mais amplo que é o da história do Brasil. Nesse sentido, a mostra se baseava em fornecer subsídios para que se vislumbrasse a "grande função histórica da cidade, cuja quadricentenária fundação comemorávamos", especialmente na "singularíssima parte que tomou na formação territorial, econômica, social e política da entidade nacional brasileira", reiterando, mais uma vez, que o próprio título da exposição já indicava "a rota e abria as vastas e necessárias perspectivas".

A Guerra dos Emboabas, disputa entre "reinóis e baianos contra "bandeirantes e mineradores" não figurou na narrativa da exposição: o assunto foi deliberadamente excluído pelos organizadores por tender "a despertar ódios de Estado ou de Nação". Cortesão menciona que a crítica do desembargador sobre a ausência do conflito na exposição se devia somente ao fato de que Soares de Melo havia cultivado "algum dia a literatura histórica, como autor de virulenta e faciosa monografia sobre os Emboabas". A "agressão" do autor, aparentemente inexplicável, fazia então sentido aos olhos de Cortesão. ${ }^{281}$ Não percamos de vista, no entanto, que o desembargador, como outros, criticara o excesso das vozes portuguesas, ou o "maior carinho" com as coisas relacionadas a Portugal. Também recordemos que uma lacuna na narrativa não explica a dissolução da Capitania de São Paulo no século XVIII. Quando, no entanto, Cortesão menciona a exclusão do assunto para evitar ódios de estado ou de nação, certamente se referia a baianos e a portugueses, que poderiam ser vistos na narrativa sobre o conflito, comparada com o restante da exposição, como forças a impedir o florescimento e a autonomização paulista. Uma vez incluído, o tema poderia divergir do tom épico, glorioso e relativamente pacífico da formação histórica paulista. ${ }^{282}$

demonstrado solidário aos exilados de Portugal e ao longo das comemorações do quarto centenário de São Paulo, lançou os Subsídios para a história da Civilização Paulista, prefaciado por Gilberto Freyre, também entusiasta de Salazar. Segundo Leonzo, Cortesão trazia à cena os debates da "história cultural" francesa, enquanto Leite evocava a tradição metódica (LEONZO, 1997, p. 39-40).

${ }^{281}$ CORTESÃO, J. Op. cit., 1955, p. 14-15.

${ }^{282}$ De acordo com Alencastro (2000, p. 203), desde o tempo da descoberta das minas em fins do XVII, a Coroa Portuguesa tomou medidas que atingiram em cheio sentimentos autonomistas dos paulistas. Santos e o litoral sul da Capitania foram submetidos ao governo do Rio de Janeiro (1698), entre 1709 e 1711, os paulistas combateram e foram derrotados na Guerra dos Emboabas. Em 1712, a Coroa adquiriu de seus donatários a capitania de Santos e São Vicente. Depois de criada a Capitania de São 
Suplantados os momentos divergentes, evitando-se também a menção ao nome de Getúlio Vargas no painel sobre o levante de 1932: ainda que se falasse no objetivo "constitucionalista", o nome do presidente contra o qual se levantavam - e que tinha se matado com um tiro no peito três dias depois de comparecer à inauguração do Ibirapuera - ficava subentendido. Narrativamente coerente, a exposição concorria mais para o seu "didatismo cívico", forjando uma identidade paulista acima de algumas das forças que puseram em xeque a liderança ou a hegemonia: fixava-se a visualidade apenas de fatos e personagens que concorressem para apresentar aos visitantes os motivos da grandeza paulista - devidamente qualificados no painel de encerramento -, que concordariam com as que veriam também do lado de fora da Oca, na Feira Industrial ou na própria cidade transformada. Tomando o livro de Cortesão como referência da sua apreensão do sentido da exposição, e baseando-se também nas suas respostas às críticas e a constante reiteração de que se tratava de uma exposição sobre São Paulo, mas inserida no quadro de um amplo processo histórico brasileiro, é possível afirmar que a mostra apresentada no Palácio de Exposições tinha por objetivo maior mostrar - a partir da utilização de mapas "inéditos" - de que forma São Paulo havia construído o Brasil. E não apenas territorialmente. E não somente no passado das bandeiras ou das monções. Lembremos da infinidade de símbolos com os quais as pessoas eram bombardeadas diuturnamente, certamente contribuindo de forma decisiva para a forma como a narrativa construída por Cortesão e seus colaboradores era apreendida.

Retomando a fala de Cortesão de 1940, a sua primeira no Brasil, na sede d' $A$ Gazeta em São Paulo, podemos compreender em parte o olhar que o historiador lançava sobre a "metrópole dos bandeirantes", espécie de "reencarnação do espírito lusíada dos Descobrimentos, coração do sertanismo épico, cujas pulsações golfaram sobre o imenso território (...) o sangue luso-brasileiro, que unificou a Pátria Nova, na

Paulo e Minas do Ouro (1709), Minas Gerais tornou-se uma capitania à parte em 1720. O terminal de ouro de Parati foi anexado à capitania fluminense (1726). Por fim, entre 1748 e 1765, São Paulo passou a ser uma dependência do Rio de Janeiro. Segundo Boxer (2002, p. 168-169) houve uma tentativa em manter escondidas as descobertas de ouro, vistas com ceticismo durante algum tempo. Depois da confirmação, a corrida do ouro trouxe para a região das Minas Gerais além dos paulistas colonos de várias partes e mesmo reinóis. Os caminhos rudes se mostraram excessivos, no entanto, para os novatos portugueses, chamados pejorativamente de emboabas pelos paulistas "por causa das polainas de couro ou pele que usavam no mato". As hostilidades entre "pioneiros" paulistas e "novatos" emboabas, em torno dos quais eram reunidos índios, criados, e africanos escravizados culminaram na guerra, que perdida pelos paulistas resultou na sua expulsão da zona aurífera. Segundo o autor, na sequência da derrota os paulistas se deslocaram para o oeste, descobrindo enfim campos auríferos em Goiás e Mato Grosso. 
mesma circulação titânica". Lançando as bases da tese que acompanharia seu percurso historiográfico brasileiro, Cortesão tornava o bandeirismo a "maior glória portuguesa", que antes de qualquer outro povo colonizador teria sido capaz de criar uma raça e uma cultura euro-americana. Difundindo-se a partir do planalto paulista, essa criação portuguesa seria o foco da "mais vasta e continuada difusão de cultura europeia, que jamais povo algum criou em mundos novos". A tal "glória portuguesa" ou "expressão heroica tão lusitana como brasileira" acompanharia o historiador em sua jornada de quase duas décadas de trabalho no Brasil. ${ }^{283}$ Seu olhar para a Pauliceia (e para o fenômeno das bandeiras), no entanto, se cruzaria com outros tantos: o dos tempos do Estado Novo brasileiro; o dos modernistas; o da historiografia paulista; o do conhecimento geográfico em autonomização; o das elites paulistas; o da intelectualidade. Na Exposição de História - inserida no amplo contexto que a engendrou - encontramos, enfim, uma interessante convergência de todos eles

Segundo Alencastro, no entanto, o equívoco de Cortesão e de parte das historiografias paulista e portuguesa residiam no fato de frequentemente desconsiderarem "os condicionantes da política ultramarina seiscentista, confundindo o escopo da primeira expansão europeia (1450-1825) com o da segunda expansão (1870-1954)". Se de um lado a historiografia paulista tendeu para a mitificação do bandeirante, como bem trabalharam os historiadores Kátia Abud (1985) e Antonio Celso Ferreira (2002), para Alencastro, Cortesão uniu-se à corrente "bandeirantista" por outros motivos, interpretando "os reides dos paulistas no Guairá espanhol e suas investidas em direção ao Norte-Noroeste" no quadro da "luta de Portugal contra a Espanha filipina". Nesse sentido, a chamada "bandeira dos limites", de Raposo Tavares (1648-1651) "visava atacar praças militares espanholas no Alto Peru". Do seu ponto de vista, o padre Antônio Vieira, buscando ocultar os motivos da empreitada, teria dado pouca importância ao alcance da expedição caracterizando-a como mera operação escravagista. A tese de Cortesão, ainda segundo Alencastro, não se sustenta pelo fato do Conselho Ultramarino ter desqualificado a ação de Tavares. Antonio Vieira, por seu turno, nunca poupou hostilidades aos bandeirantes, considerando-os mais detestáveis que os castelhanos. Projetando pontos de vista e atitudes próprias do nacionalismo e das corridas

\footnotetext{
${ }^{283}$ Cortesão, J. A Certidão de Nascimento do Brasil e do Novo Mundo. Conferência. São Paulo,
} dez. 1940. BNP/ACPC E25/40. 
imperialistas oitocentistas na ocupação dos territórios ultramarinos nos séculos anteriores incorreria, portanto, em leituras anacrônicas. ${ }^{284}$

Some-se ainda à interpretação feita por Alencastro a apreensão do bandeirismo em consonância com os projetos políticos, culturais e territoriais da Era Vargas, notadamente pelas bases lançadas durante o período 1930-1945 e que não foram superadas após a deposição de Vargas e o fim do Estado Novo. De Gustavo Capanema a Osvaldo Aranha, passando por toda a rede formada por órgãos como o Instituto Rio Branco, o SPHAN, o IBGE, a Biblioteca Nacional, Cortesão integrou-se a um privilegiado espaço de debates e de ações sistemáticas em nível nacional. Tendo acesso a muitos dos documentos - entre os quais diversos inéditos - sobre as bandeiras e o que chamou de "formação territorial do Brasil", o historiador português construiu os programas dos cursos de aperfeiçoamento de diplomatas que ministrou no Itamaraty, teve seus trabalhos publicados sob os selos da Biblioteca Nacional e dos Ministérios da Educação e das Relações Exteriores e, ainda, abriu o caminho para ser o organizador da Exposição de História de São Paulo.

No quadro das demandas ao conhecimento histórico e geográfico no projeto de integração nacional daqueles tempos, os "bandeirantes de Cortesão" se encontraram com os "bandeirantes dos paulistas" - do passado, do presente e do futuro, aludindo à feliz interpretação de Marins que aqui apresentei - e com a hegemonia que a cidade e o estado desejavam impor. Como também vimos, do estudo de Mônica Velloso, em tempos de nacionalismo, o regionalismo paulista e seu heroico "integrador" bandeirante, assim como o modernismo em suas correntes, transformaram o olhar para o passado colonial e se tornaram dominantes. Ao menos na Exposição de História, a estética modernista e o olhar para o "paulista" como agente máximo da integração e da conformação do Brasil em seus traços característicos deram o tom de como São Paulo teria composto o "quadro da história do Brasil" e de como poderia ser um paradigma para o país no presente/futuro. Cortesão, com tintas portuguesas, emoldurava a exposição e a sua narrativa em um quadro ainda mais amplo: o da expansão portuguesa e das peculiares características da colonização lusa no que diz respeito à relação com os povos nativos.

Na História do Brasil nos Velhos Mapas, obra entregue por Cortesão ao Instituto Rio Branco antes de seu retorno definitivo para Portugal em 1957, é possível

\footnotetext{
${ }^{284}$ Alencastro, L. F., Op. cit., 2000, p. 333-335.
} 
apreender as mesmas matrizes que compuseram o quadro da exposição de 1954. Na obra, o autor apresentou a estudiosos do assunto aquela que seria, "por definição e primazia, uma história do descobrimento, formação e soberania territorial do Brasil, exemplificada a cada passo pela cartografia antiga, comparada com a moderna". Segundo Cortesão, nenhum Estado contemporâneo teria sua história política tão relacionada com a história da geografia e da cartografia como o Brasil, lembrandose do papel desempenhado por figuras como o Barão do Rio Branco, "geógrafo e historiador da geografia e da cartografia", tal como seus precursores. ${ }^{285}$

Conforme a apresentação da recente edição de 2009 da obra, dessa vez no âmbito da coleção Obras Completas de Jaime Cortesão, então no 11. ${ }^{\circ}$ volume, Joaquim Romero Magalhães salientou os estudos de Cortesão no Brasil como os seus "maiores", majoritariamente impressos pelas editoras oficiais - à exceção da Carta de Pero Vaz de Caminha, de A Fundação de São Paulo e da Pauliceae Monumenta Historicadescrevendo o título então apresentado como preparação e reprodução das lições no Instituto Rio Branco. Diversos percalços encontraria o texto antes de vir à lume, como demonstra a intensa troca de correspondências entre Carolina Cortesão e Maria Vilhena de Araújo. Em dezembro de 1965, Araújo exclamava após os anos de espera para a publicação do primeiro tomo, remetendo do Brasil para Portugal exemplares para Salazar e para historiadores e professores como Damião Peres, Hernani Cidade, Vitorino Magalhães Godinho, Virgínia Rau, entre outros. ${ }^{286} \mathrm{Em}$ 1971 sairia o segundo volume. A publicação ficou bastante restrita e por isso, pouco conhecida especialmente em Portugal, segundo Magalhães. ${ }^{287}$

No texto, o autor fornece importantes subsídios para a leitura da cartografia histórica, ajudando a iluminar questões da diplomacia, da história, da geografia. Além de permitir a compreensão da sua epistemologia, Cortesão descreve nos Fundamentos geográficos do Estado brasileiro o papel de São Paulo e de Belém no processo de interiorização da colonização portuguesa da América do Sul, trazendo

\footnotetext{
${ }^{285}$ CORTESÃO, J. História do Brasil nos Velhos Mapas, t. 1. Lisboa: Imprensa Nacional/Casa da Moeda, 2009, p. 21. (Coleção Obras Completas de Jaime Cortesão, v. 11).

${ }^{286}$ ARAÚJO, M. V. Correspondências a Carolina Cortesão. Rio de Janeiro, 20 dez. 1965/3 jan. 1966. BNP/ACPC E25/2207; 2209. No Espólio Jaime Cortesão, na série Correspondência de terceiros, encontram-se diversas missivas encaminhadas à viúva do autor, entre elas diversas tratando da publicação de seus textos, bem como homenagens. Maria Vilhena de Araújo, do Ministério das Relações Exteriores, é uma das correspondentes mais assíduas, tendo registradas no arquivo 43 cartas, sendo a primeira de agosto de 1960 - de condolências - e a última de janeiro de 1966, uma das citadas. ${ }^{287}$ MAGAlHÃes, J. R. Apresentação. In: CORTESÃO, J. Op. cit., t. 1, 2009, p. 13-14.
} 
à discussão Capistrano de Abreu. Dessa forma, o historiador português ainda dava sentido ao que chamava de "predestinações geográficas da colonização", impostas pelo relevo do continente, e que já haviam feito parte de estudos e expedições desde o século XIX:

Outra das particularidades do relevo foi eminentemente favorável à penetração do território. Referimo-nos à disposição recíproca das cadeias central e litorais, aquela, grosso modo, perpendicular a estas, permitindo assim - caso singularíssimo - que a bacia do Prata se aproxime tanto do Atlântico, nas suas origens, que o Tietê, afluente do Paraná, nasça a 15 quilômetros da baía de Santos. Capistrano de Abreu chamou a atenção para a importância que teve desde as origens da história do Brasil o curso do Tietê, pela sua posição e direção. A sua proximidade do Atlântico permitiu que os primeiros colonos, galgando a Serra do Mar, viessem estabelecer-se sobre o planalto, nas suas margens. O seu curso, pois os colonos não tinham que subi-lo, mas descê-lo, favoreceu a penetração do interior; finalmente a confluência no Paraná facilitou o contato com os afluentes do Paraguai. São Paulo, criação, em boa parte, do Tietê, e Belém do Pará, criação do Amazonas, tornaram-se com o tempo dois grandes cais de embarque dos portugueses nas suas viagens de exploração e expansão por quase todo o interior do Brasil. ${ }^{288}$

A narrativa da conquista do sertão não poderia, portanto, prescindir de São Paulo. As elaborações de Cortesão, baseadas em tantos documentos e interpretações inéditos, inicialmente restritas a diplomatas e a servidores do Ministério das Relações Exteriores ou de outras instituições federais, encontraria na Exposição de História a grande visibilidade (do trabalho e do autor) que nenhum curso ou publicação ofereceria. A didática, cívica e científica exposição colocaria um grande público, ávido por conhecer (e celebrar) a história de São Paulo e do Brasil, em contato com as contribuições de Cortesão, sendo mais uma importante via de reconhecimento de sua produção historiográfica e de difusão de seus trabalhos.

Alguns vestígios permitem perceber, nesse sentido, a forma como a linguagem dos museus teria acompanhado Cortesão após o encerramento de seus trabalhos junto à CIVCCSP. Em um texto escrito em abril de 1956, quando passava uma temporada em Estoril, Cortesão delineou o que seria o Museu dos Descobrimentos, a ser instalado na capital portuguesa: o espaço havia sido previsto pelo governo português, que abriu um concurso em 1954 para selecionar o projeto que seria executado. O texto consta de uma correspondência enviada aos arquitetos Carlos e Guilherme Rebelo de Andrade, que tinham convidado Cortesão para ser o consultor nos assuntos de história e também o planejador/executor do que seria o museu.

${ }^{288}$ CORTESÃo, J. Op. cit., t. 1, 2009, p. 37-38. 
Recebendo pelo trabalho, o historiador pedia "a superior direção e liberdade na execução", mencionando como colaboradores Leitão de Barros, Álvaro de Brée, Martins Barata e um de seus principais colaboradores na Exposição de História de São Paulo, representando o modernismo português, Manuel Lapa.

As seções da Exposição de História de São Paulo - as seis de Cortesão - aparecem sob os mesmos títulos e lançando mão essencialmente dos mesmos objetos e recursos no plano do Museu dos Descobrimentos. Na descrição da primeira seção, Cortesão informava aos arquitetos que aproveitaria naquela o material cartográfico preparado para a exposição de São Paulo. Na segunda, chama de "tupinização" o processo de adaptação dos colonos portugueses à cultura indígena (no singular), salientando que os exemplos selecionados eram "todos tupi!": reiterava no segmento as características que teriam composto o português e lhe tornado o colonizador dotado de "amorabilidade franciscana" a criar os princípios de uma "civilização própria". Da terceira à sexta seção, o assunto se dedicava, como sabemos, a São Paulo e à sua fundação, à mineração e ao seu papel na formação dos limites do Brasil. ${ }^{289}$ Em suma, não eram apenas os materiais cartográficos da exposição de 1954 que seriam aproveitados: a partir do que se havia realizado na Oca do Ibirapuera para narrar o papel paulista na formação do Brasil, Cortesão pretendia também compor o museu destinado a narrar os Descobrimentos. Ainda que o plano não tenha logrado êxito nem o de Cortesão e dos arquitetos, nem o de um museu dedicado às descobertas não foi possível identificar se e nem quais outros elementos seriam adicionados ao plano então apresentado. De qualquer modo, ratificava-se o "enquadramento" das histórias paulista e brasileira na história de Portugal, baseando uma nova narrativa museológica no pouco ou nada modificado plano de Cortesão executado no Ibirapuera.

Em 1958, reunido no conjunto "Cartas de Portugal", encontra-se um texto intitulado "Introdução histórica aos museus de arte portugueses", levando também a inferir quais poderiam ter sido os caminhos de Cortesão após o seu retorno a Portugal. No escrito, o autor "um quarto de século" fora do país comentou o crescimento do número de museus de arte, instituições que segundo o historiador poderiam renovar e enriquecer a "consciência de nação", além de melhorar o

\footnotetext{
${ }^{289}$ CORTESÃO, J. Documentação para o Museu dos Descobrimentos. Acompanha correspondência a Carlos e Guilherme Rebelo de Andrade. Estoril, 17 abr. 1956. BNP/ACPC E25/Pasta 5.
} 
interesse, o gosto e a cultura artística do público. Ademais, Jaime Cortesão disse do incremento das visitações às exposições e do desejo no país de perpetuar e renovar a sua história a partir de uma valorização de seu passado de "grande pátria". Para tanto, lembrou o papel do ex-presidente Antônio José de Almeida (1919-1923), antes de quem nenhum outro governante português teria se empenhado no setor da educação. Nos tempos da gestão de Almeida, Cortesão dirigia a Biblioteca Nacional de Portugal.

Cortesão ainda mencionou o trabalho de José de Figueiredo - ao lado de quem já havia atuado - e do Museu Nacional de Arte Antiga. De acordo com o historiador, Figueiredo havia revolucionado a forma de dispor as obras de arte em salas, sendo assim um "dos grandes renovadores da museologia", adotando práticas antes delas serem largamente adotadas em muitos museus estrangeiros. Tais práticas consistiriam na exposição de obras-primas em espaços amplos, para que não houvesse prejuízo entre elas, além do recurso da harmonização entre ambiente e obras: colocava-se fim ao "museu-armazém". Para dar suporte às suas afirmações sobre Figueiredo, Cortesão mencionou a revista Muséographie, que destacou o trabalho do português e o recomendou, tendo sido então adotado pelos museus do Louvre, do Prado e Nacional de Florença. ${ }^{290}$

Seguindo pela vereda aberta por essas fontes - ambas posteriores à experiência brasileira e aos intensos trabalhos em torno da exposição paulista de 1954 - pudemos notar tanto certo interesse pela temática dos museus como também de que forma Cortesão percebia esses espaços. Ao que sugerem tais textos, o historiador olhava com expectativas o aumento do interesse do público pelos museus e do desejo dessa população de "renovar" da história de Portugal: duas informações que apresentariam o fértil terreno a explorar, lançando as sementes que havia descoberto - ou amadurecido - no Brasil. No exílio, além de descobrir a história nos arquivos e nos mapas, percebia que museus e exposições também poderiam ser um caminho muito proveitoso para animar a "consciência de nação". Era mais uma peça no seu projeto de fazer "renascer" Portugal.

Tathianni Silva (2014), em seu trabalho sobre o intelectual Mário Neme, um dos colaboradores mais atuantes de Cortesão na Exposição de História, indica um

\footnotetext{
${ }^{290}$ CORTESÃO, J. Introdução histórica aos museus de arte portugueses. Cartas de Portugal. Lisboa,
} 1958. BNP/ACPC E25/35. 
interessante percurso de análise para as consequências daquele trabalho realizado pelo grupo liderado pelo historiador português. O piracicabano Neme, logo após as atividades na exposição - onde atuou especialmente por ser servidor público municipal - foi indicado para dirigir a Casa do Bandeirante (espaço museológico na região do Butantã, cidade de São Paulo) e em 1960 assumiu a direção do Museu Paulista. No MP, promoveu a sua integração à Universidade de São Paulo, tencionando criar uma instituição ao mesmo tempo pedagógica e científica. As diversas mudanças que empreendeu, de acordo com a visão da Nova Museologia, buscou transformar o espaço em "um museu de conceito contemporâneo sobre a História do Brasil, com ênfase no período colonial". Silva ainda menciona que "enquanto um intelectual modernista que acreditava na educação como mediadora de conflitos sociais", Neme imprimia a sua marca e construía em torno de si "um grande leque de possibilidades e contatos que the favoreceram intensamente durante a sua gestão à frente do museu". ${ }^{291}$

As visitas que Mário Neme havia feito a Portugal e os diálogos empreendidos por meio da "nova museologia" de João Couto, que tinha transformado "a maneira de se trabalhar e pensar os espaços museológicos", tiveram bastante influência sobre o trabalho do intelectual à frente do Museu Paulista. Couto, na direção do Museu Nacional de Arte Antiga, procurando "inserir Portugal com seus museus, no circuito de visitações e discussões acerca do assunto no contexto europeu", deu importância à educação, à conservação e ao restauro, à produção científica e à formação de profissionais, iniciativas que também foram marcantes da gestão de Neme. Participando ativamente do delineamento de uma futura política para os museus brasileiros, Neme mobilizou sua experiência na organização da Exposição de História, na Junta Coordenadora dos Museus Municipais de São Paulo e por fim no Museu Paulista. ${ }^{292}$ Desse modo, tanto em Neme quanto em Cortesão - e também em Ernani Silva Bruno, que esteve à frente do Museu da Casa Brasileira (São Paulo) ${ }^{293}$ - são

\footnotetext{
${ }^{291}$ SILVA, T. C. Op. cit., 2014, p. 85; 96-97. Registre-se ainda que, segundo a autora, Neme fazia parte das revistas Clima e Planalto e era um importante elo entre os intelectuais da Universidade - os "moços" da Clima - e os intelectuais "da cidade". Além disso, cabe ressaltar que, antes de Neme, o Museu Paulista havia sido dirigido por Afonso Taunay entre 1917 e 1945; Sérgio Buarque de Holanda e Herbert Baldus (especialmente na área de etnografia) entre 1946 e 1956; Herbert Baldus entre 1957 e 1959. Neme chegou à direção do Museu Paulista por intermédio de Paulo Duarte.

${ }^{292}$ SiLVA, T. C. Op. cit., 2014, p. 170-171; 192.

${ }^{293}$ Ernani Silva Bruno foi o primeiro diretor do atual Museu da Casa Brasileira, criado no início da década de 1970 em São Paulo como Museu do Mobiliário Artístico e Histórico Brasileiro,
} 
identificáveis algumas das sementes lançadas a partir da organização da exposição de 1954 somente no campo da museologia.

Em um trabalho clássico, no qual se dedicou a analisar o processo de construção de estados nacionais, Benedict Anderson destacou especial atenção à comunicação. Nesse sentido, em um dos capítulos de Comunidades imaginadas, o autor caracterizou os papéis desempenhados por mapas e museus nesse processo, bem como os censos. Interligados, os três compunham uma "grade classificatória totalizante" passível de ser posta sobre praticamente "qualquer coisa sob o controle real ou apenas visual do Estado: povos, regiões, religiões, línguas, objetos produzidos, monumentos, e assim por diante". Dessa forma, sempre seria possível dizer que uma coisa qualquer fazia parte de um grupo ou de outro; era uma coisa e não outra. ${ }^{294}$

Ainda que se tenha frequentemente dito que a Exposição de História tenha tido caráter "científico", é importante salientar que não se tratava ali de um texto monográfico. A semelhança residiria sobretudo na linha argumentativa, na justificativa das seleções, na conformação de uma relevância do que se apresenta. A diferença, por sua vez, estaria no fato de que na exposição os objetos são mais relevantes do que o sentido que deles se constrói. ${ }^{295}$ Além disso, em uma exposição, o visitante não se restringe à mediação feita pela linguagem: ele próprio "é a relação com o mundo do qual ela trata (...) pela mediação perceptiva e corporal dos objetos e do espaço". Toda aquela disposição chegou ao visitante de alguma maneira, ao mesmo tempo em que a organização da mostra fez com que cada objeto se tornasse para o visitante o meio de transportá-lo e imergi-lo a esse mundo. ${ }^{296} \mathrm{O}$ público visitante da Exposição de História de São Paulo no quadro da História do Brasil percebia então, no interior de um edifício de "ousada arquitetura" os objetos que o permitiam

\footnotetext{
funcionando desde 1972 em um solar neoclássico que foi residência do ex-prefeito Fábio Prado. Disponível em: <http://www.mcb.org.br>, acesso em 19 jul. 2015.

${ }^{294}$ ANDERSON, B. Comunidades imaginadas: reflexões sobre a origem e a difusão do nacionalismo. São Paulo: Companhia das Letras, 2008, p. 253. Ainda que o autor trate especialmente do Estado colonial tardio e de realidades do Sudeste da Ásia, tais elaborações lançam luzes sobre operações relacionadas à produção do conhecimento em sociedades que têm em comum o passado colonial, sobretudo em momentos em que o conhecimento produzido remete diretamente a esse passado.

${ }^{295}$ MeNESES, U. T. B. Do teatro da memória ao laboratório da História: a exposição museológica e o conhecimento histórico. In: Anais do Museu Paulista, São Paulo, n. ser., v. 2, 1994, p. 37-38.

${ }^{296}$ DeVAlLON, J. Comunicação e Sociedade: pensar a concepção da exposição. In: BENCHETRIT, S. F. et al. (org.). Museus e comunicação: exposições como objeto de estudo. Rio de Janeiro: Museu Histórico Nacional, 2010, p. 24-25.
} 
acessar ao mundo que teria composto a grandeza e a peculiaridade de São Paulo. ${ }^{297}$ A partir disso, construindo a sua interpretação, cada visitante poderia identificar como cada matriz exposta teria formado a identidade paulista e a identidade nacional.

A despeito de ter qualificado sua contribuição às comemorações do quarto centenário de São Paulo como altamente cuidadosas com o trato dos assuntos da história paulista e de suas figuras, eventos e documentos mais relevantes, inseridos em um dos marcos de sua arquitetura e pautados pela originalidade e pelo ineditismo, Jaime Cortesão, auxiliado decisivamente pelos portugueses radicados no Brasil e pelo governo de seu país - apesar de ter sido banido pelo mesmo governo menos há menos de duas décadas - inseriu a organização da exposição no quadro dos feitos de Portugal no mundo. De seu ponto de vista, e em resposta aos que lhe disseram demasiadamente cuidadoso das coisas de Portugal, as categorias de cidadão brasileiro e português se fundiriam numa única: "uma das melhores formas de ser português" seria "amar e servir o Brasil". ${ }^{298}$ Entretanto, no quadro da sua trajetória e da circulação de ideias relacionadas à história da colonização portuguesa no mundo, valorizando sobretudo a plasticidade, a adaptação aos povos naturais das regiões colonizadas e visibilizando uma "comunidade de cultura" entre os povos de língua oficial portuguesa, o sentido da declaração de Cortesão não é meramente uma frase-feita.

\footnotetext{
${ }^{297}$ Um interessante trabalho de Camilo de Mello Vasconcellos sobre o Museu Nacional de História do México entre os anos de 1940 e 1982 permite observar um outro caso em que tradição, modernidade, conhecimento histórico, patrimônio, memória se articularam em torno de questões como identidade nacional e apreensões do passado de acordo com as demandas do presente. Destaco, especialmente, a abordagem sobre o recurso dos murais, que se difundiu para muito além do caso mexicano. Cf. VAsConcellos, C. M. Imagens da Revolução Mexicana: o Museu Nacional de História do México (1940-1982). São Paulo: Alameda, 2007.

${ }^{298}$ CORTESÃO, J. Op. cit., 1955, p. 17. De qualquer modo, Fernando Lemos, artista português que se estabeleceu no Brasil desde os tempos da exposição, incluiu o texto que compõe o Guia para o Visitante, assinado por Agostinho da Silva, Ernani Silva Bruno, Hélio Damante e Mário Neme, em uma coletânea batizada de "A Missão Portuguesa: rotas entrecruzadas. Cf. LEMOS, F.; LEITE, R. M. (org.). A Missão Portuguesa: rotas entrecruzadas. São Paulo: Ed. UNESP; Bauru: EDUSC, 2003.
} 


\section{CApítulo 3.}

\section{Uma historiografia das relações: especificidades da colonização portuguesa, poder e produção do conhecimento}

\section{Índios, bandeirantes e uma família luso-tupi no planalto paulista}

Pouco tempo antes de partir definitivamente para Portugal, onde seria novamente detido por conta de suas ações políticas (e libertado graças à intervenção de intelectuais brasileiros) ${ }^{299}$, Cortesão se empenhou na publicação de Raposo Tavares e a Formação Territorial do Brasil, ideia que havia nascido catorze anos antes, à época do primeiro curso no Itamaraty, quando a figura de Raposo Tavares havia se mostrado de "excepcional grandeza". Dizendo que o sertanista havia alargado inigualavelmente "os alicerces geográficos do Brasil", Cortesão estranhava os "mistérios e enigmas" relacionados aos objetivos e percursos da empreitada de Tavares. Os documentos sobre a "maior bandeira" foram reunidos e esperaram pelo momento de serem apresentados em uma obra, cujo objetivo seria o de restituir aos bandeirantes, especialmente a Raposo Tavares, uma "visão mais correta", visto que uma "lenda negra (...) lhes deturpara a memória". Cortesão expressou na obra que poderia ter empreendido tal restituição no curso do Itamaraty; no entanto, lembrou que os objetivos na ocasião eram outros. A organização da Exposição de História de São Paulo, absorvendo o tempo de Cortesão, também postergou a execução do projeto.

Em 1956, Jaime Cortesão, em companhia do então embaixador - e empresário, jornalista, mecenas - Assis Chateaubriand, fez uma visita ao "velho e querido amigo", o editor Ricardo Seabra. ${ }^{300}$ Chateaubriand, conhecedor da intenção de Cortesão, insinuou a Seabra a conveniência de uma "obra renovadora sobre o português que soubera tornar-se a figura máxima do bandeirismo e [que] tamanha importância assumia na história do Brasil". Após a conversa, Seabra ofereceu a

\footnotetext{
${ }^{299}$ Em 22 de novembro de 1958 Cortesão foi preso em Portugal junto de Antonio Sergio, Vieira de Almeida e Mario de Azevedo Gomes. A prisão, que teria sido motivada pelo endosso dos intelectuais à visita de um líder trabalhista inglês, Aneurin Bevan, foi questionada por articulistas brasileiros como Rubem Braga e mobilizaram a opinião pública brasileira (LEONZO, 1997, p. 35).

${ }^{300}$ Ricardo Seabra era português e sua casa era frequentada por Cortesão e Aquilino Ribeiro, que os aproximara (RIBEIRO, 1952, p. 189).
} 
Cortesão o financiamento e a sua editora para viabilizar a obra. Dois anos depois da conversa e de renovar as pesquisas, o livro era publicado sob o selo do Ministério da Educação e Cultura. ${ }^{301}$

Àquela época, lembramos, publicava-se a documentação que Cortesão tinha organizado na Biblioteca Nacional, dos Manuscritos da Coleção De Angelis, na qual se apresentavam documentos inéditos sobre as bandeiras de Raposo Tavares. O texto, um dos últimos publicados no Brasil quando Cortesão ainda estava vivo, objetivou também demonstrar "como se formou em São Paulo e floresceu de raiz luso-tupi um gênero de vida novo, o bandeirismo". ${ }^{302}$ Gênero de vida que tinha, de seu ponto de vista, a maior expressão em Raposo Tavares. Desse ponto, em que se considera o protagonismo bandeirante na construção das relações que deram origem ao Brasil geográfica e historicamente - pode-se aprofundar a leitura dos caminhos historiográficos de Cortesão, especialmente transformados pelas experiências brasileiras.

Ainda que o objetivo aqui não seja o de analisar pormenorizadamente as obras de Cortesão, e sim de identificar os traços dos percursos de sua escrita, é importante registrar que tanto em A Fundação de São Paulo, em Raposo Tavares, e na História do Brasil nos Velhos Mapas, antes de caracterizar a "fusão" entre portugueses e índios, o autor qualifica os dois grupos, não sem imprimir nesses parâmetros juízos de valor e ideias mais ou menos datadas.

Em A Fundação de São Paulo, um subtítulo da primeira parte é dedicado a versar sobre "Onde a cultura dos primitivos tem as suas vantagens": além de discutir sobre a apreensão das terras sul-americanas pelos nativos, o texto procura identificar grupos e regiões geográficas no continente e os "fundamentos" sobre os quais teria se prefigurado o Brasil, que viria a nascer da vasta região de florestas tropicais - uma unidade territorial - e dos povos que nela se estabeleceram desde "tempos préhistóricos". Dos dois grandes grupos dessa região - identificados como Tupi-guarani e Aruaque - Cortesão opta por falar apenas sobre o primeiro, "com quem o português entrou mais rápida e intensamente em contato", além de ser o que "maior influência veio a ter na formação territorial do Estado e no hibridismo étnico e cultural, de que saíram as bandeiras e os bandeirantes paulistas". Valorizando o seu "sentido

\footnotetext{
${ }^{301}$ CORTESÃO, J. Raposo Tavares e a formação territorial do Brasil. Rio de Janeiro: Ministério da Educação e Cultura, 1958, p. 1-2.

${ }^{302}$ CORTESÃO, J. Op. cit., 1958, p. 3.
} 
topográfico, a capacidade de representar o espaço percorrido e, como consequência a cultura geográfica (...)", o papel do indígena é apresentado de forma semelhante ao que se fez na Exposição de História nas seções iniciais, lançando luz somente aos que teriam "contribuído" com a colonização portuguesa, especialmente por cobrirem grandes distâncias:

(...) a cultura indígena e a língua geral, produtos duma unidade geográfica, econômica e humana, representavam uma força poderosa de agregação política. Ao começar o século de Quinhentos, já os tupi-guarani prefiguravam sobre o território, ainda que sob forma ondeante, a fundação colonial dos portugueses, na América do Sul. ${ }^{303}$

Nesse sentido, os povos Tupi-guarani, que se "fundiriam" com os portugueses, igualmente dotados de "consciência do espaço", teriam sido a perfeita relação que revelaria a unidade geográfica de uma nação futura. Quase um "mito de fundação", a narrativa de Cortesão baseia-se na escolha de uma entre tantas sociedades habitantes de uma vasta região, escamoteando a complexidade das suas relações com o espaço para fixar uma simplificação que explicaria, entre outras coisas, as relações com colonizador europeu.

Já na História do Brasil nos Velhos Mapas, o papel indígena foi enquadrado nos "fundamentos pré-históricos" do Estado brasileiro e nas "origens indígenas" do mito de uma "Ilha Brasil". Na obra, o raciocínio é o mesmo que se verifica no texto sobre a fundação de São Paulo, aprofundado com análises de mapas de "zonas de cultura geográfica indígena" no século XVI e "áreas culturais da América meridional segundo Wissler". Referindo-se a Sérgio Buarque de Holanda, Cortesão explora ainda a representação cartográfica e as convenções utilizadas por índios do Alto Xingu, apresentada por Karl von den Steinen no século XIX. Na ocasião, lembra o que o "notabilíssimo" historiador paulista havia trabalhado sobre tais documentos. Em uma nota de rodapé, Cortesão esclarece que Sérgio Buarque e ele "escreveram simultaneamente e independentemente um do outro sobre o mesmo tema", ressaltando que seus conceitos e fontes vinham sendo citados e expostos "desde 1944", quando dos cursos do Itamaraty, e também nos artigos publicados entre 1947 e 1948 n'A Manhã e n'OESP. ${ }^{304}$

Recurso apresentado igualmente na Exposição de História, o mapa das "Vias de Difusão Cultural" indígena, baseados nos mapas e estudos de Nordenskjöld, também

${ }^{303}$ CORTESÃO, J. Op. cit., 1955, p. 45-48; 51-52; 62-63.

${ }^{304}$ CORTESÃO, J. Op. cit., t. 1, 2009, p. 55-56. 
compôs o estudo sobre os fundamentos "pré-históricos" brasileiros representados pelos grupos indígenas sul-americanos, novamente dando ênfase ao papel dos povos nativos na difusão de elementos culturais europeus e no aproveitamento pelos adventícios da rede de caminhos anterior à sua chegada. Destacando o aprendizado dos portugueses dos primeiros tempos da colonização dos cultivos da mandioca e do milho, bem como das longas marchas a pé, Cortesão menciona ainda que apesar dos "enormes serviços que prestaram à expansão portuguesa na América do Sul", as populações indígenas, caracterizadas como Tupi, teriam demonstrado "escasso préstimo, (...) para auxiliar os primeiros colonos no cultivo da cana e no fabrico do açúcar", o que forçaria a importação da mão-de-obra africana. Lançando mão dos padrões sociais europeus, o autor descreve a organização social dos africanos, referindo que sua "unidade social mais típica era a tribo". Entre outras características mobilizadas, a população negra, mais sedentária, teria "capacidades geográficas" inferiores às dos ameríndios. Por fim, o historiador concluía a explanação da mesma forma e basicamente com as mesmas palavras do texto anteriormente citado, atribuindo à cultura indígena e à língua geral a "força poderosa de agregação" que teria viabilizado a "fundação colonial dos portugueses na América do Sul" prefigurada pelos Tupi-guarani. ${ }^{305}$

Texto provavelmente preparado após os dois citados, Raposo Tavares e a formação territorial do Brasil trouxe em sua introdução um quadro da "Geografia e etnografia da América do Sul". Começando, como de praxe, pela "terra", Cortesão menciona igualmente a excepcionalidade da história do Brasil no que se refere aos seus fundamentos "pré-históricos" e "geográficos". Seu delineamento do espaço geográfico "brasileiro" é descrito em comparação com os continentes africano e europeu, marcando sobretudo as condições que a vegetação, o relevo e a hidrografia teriam imposto à circulação e à fixação humanas. Mais uma vez, Cortesão menciona a "unidade geográfica" de uma "formação insular de floresta tropical de planície, limitada pelos grandes desníveis de terreno, - serras, cachoeiras e pantanais", que correspondia igualmente a "uma unidade econômica, realizada ou a realizar, quando os portugueses aportaram às costas do Brasil (...)". 306

\footnotetext{
${ }^{305}$ CORTESÃO, J. Op. cit., t. 1, 2009, p. 69-71.

${ }^{306}$ CORTESÃo, J. Op. cit., 1958, p. 13.
} 
Em conclusão à primeira parte do texto introdutório da obra, Cortesão responde à questão que havia colocado em $A$ Fundação de São Paulo, sobre como teria sido a reação dos colonos portugueses diante da revelação de uma "unidade, mais inviolável que o Tratado de Tordesilhas". Conforme o autor, o "longo processo de exploração dos sertões, criações míticas, especulações científicas e reivindicações políticas", realizado por Raposo Tavares e sancionado pelo Tratado de Madri, narraria a história da formação territorial do Brasil empreendida por colonos/bandeirantes em "reação" aos ditames do Reino de Castela - no quadro da sujeição da Coroa Portuguesa ao cetro dos Filipes - e à inviabilidade do Tratado de Tordesilhas. ${ }^{307}$

A "terra" e o "homem", pontos de partida para as elaborações desenvolvidas em grande parte de seus textos, correspondendo ao que seriam domínios da geografia e da história, respectivamente, são, no caso do Brasil, fundados sobre o que denomina a "pré-história" dos povos indígenas e a tal "unidade geográfica" do que viria a ser o país. Nesse sentido, a "cultura geográfica" dos povos Tupi-guarani, definida como um dos poucos pontos em comum entre esses índios (separados dos demais povos) e os portugueses, era apresentada ainda como signo de superioridade: distinção essa que se baseava na similaridade com um modelo europeu.

Igualmente presente na Exposição de História, o olhar do português para o índio - Tupi-guarani por excelência - era justificado a partir da valorização de seus conhecimentos geográficos; dos relacionados à sobrevivência, como a caça, a pesca, a agricultura; de seu papel na difusão de artefatos e elementos culturais europeus. Acima dos outros povos indígenas sul-americanos, os Tupi-guarani haviam alcançado a honra de figurar na narrativa histórica do Brasil (embora como elementos "pré-históricos" do país) dada a sua contribuição para a colonização dos portugueses, que erigiriam politicamente um Estado onde havia apenas uma "unidade geográfica".

Retomando a reflexão de Jorge Borges de Macedo (apresentada no primeiro capítulo) acerca do fator geográfico que permearia a produção historiográfica de Cortesão e à luz do que vimos até aqui, podemos compreender o que Macedo caracterizou como sendo o "ponto de suporte" que ajudaria a entender o problema da "unidade" de um grupo social. Para Cortesão, o fator geográfico estaria na base

${ }^{307}$ CORTESÃO, J. Op. cit., 1958, p. 25. 
dessa compreensão, mas enquanto ponto de partida, porque, de acordo com Macedo, ele dependeria de outras análises subsequentes, relacionadas à história social e à história econômica - considerando assim o ponto de vista de Fernand Braudel ${ }^{308}$ para, enfim, atingir as camadas da história da "unidade espiritual" e dos "ideais coletivos" que seriam, a partir do que se depreende de Macedo, o objetivo a ser atingido por Cortesão no seu ato de escrever história. ${ }^{309}$

Partindo disso e seguindo a trilha indicada por Macedo, a história (da colonização portuguesa) do Brasil, depois de analisado e compreendido o fator geográfico da unidade - sempre a unidade - do corpo que se tornaria um Estado nacional, seria melhor explicada mobilizando outros instrumentos, com vistas a atingir as camadas da chamada "unidade espiritual" e dos "ideais coletivos". Tomando como objetos especiais a serem interpretados segundo essa perspectiva a Exposição de História e as relações entre portugueses e índios que são enunciadas nas elaborações acima apresentadas, é possível apreender algumas nuances da compreensão de Cortesão sobre a dinâmica da colonização portuguesa que abordarei ao longo deste capítulo.

$\mathrm{Na}$ segunda seção da exposição, especialmente, dedicada a apresentar o encontro entre português e indígena, considerou-se, antes de mais nada, essa relação como a matriz de diversas especificidades da cultura brasileira e, sobretudo, da paulista. Em vista das formas diversas de cultura indígena, destacaram-se, como vimos, as "reações" de uma cultura portuguesa, plasmada por antigos e modernos representantes de um mundo "Ocidental" devidamente pormenorizado e exposto em algumas de suas realizações artísticas, literárias e científicas. Mesmo considerando os povos árabes, o destaque maior ficou para gregos, romanos, italianos, franceses, espanhóis, holandeses - e para o português do campo que também estaria a bordo das embarcações a aportarem nos litorais sul-americanos.

A tupinização era marcada como um processo inicial, ao qual o colono se submeteria para sobreviver: ficava por conta da cultura material de povos Tupi, selecionados por "motivos óbvios", e por fotografias que demonstravam a manutenção de costumes narrados por viajantes e cronistas, a indicação de que, de fato, aqueles eram registros "pré-históricos", senão "a-históricos". Ainda que

\footnotetext{
${ }^{308}$ Refiro-me à divisão conceitual entre "História Econômica" e "História Social", que são expressas em BRAUDEL, F. História e Ciências Sociais. 6a ed. Lisboa: Presença, 1990.

${ }^{309}$ MACEDO, J. B. Op. cit., 1984, p. 63.
} 
houvesse a intenção válida de inserir a cultura indígena - embora singularizada e essencializada no Tupi - no quadro das matrizes primeiras de São Paulo e do Brasil, a sequência do percurso expositivo apresentava uma superação daqueles que eram vestígios de culturas espacial e temporalmente distantes, diluídas em uma "consciência" que teria sido herdada pelos paulistas por intermédio de bandeirantes, a expressão máxima da fusão e representação do modo de vida legitimamente paulista, descrita nas seções seguintes com vagar. Apenas a "cultura geográfica", e a noção de um "Brasil uno" seriam aproveitados na identidade local e nacional, liderada pelos portugueses/europeus "criadores de história".

À população negra, como ficou patente não apenas na segunda como em todo o conjunto da exposição e das comemorações centenárias, a referência era quase invisível: inicialmente por máscaras e outros objetos da "África Portuguesa", depois por menções à expressão religiosa no tempo da mineração e, por fim, quando do movimento abolicionista. O percurso expositivo, bem como o dos trabalhos de Cortesão, desenhava uma São Paulo e um Brasil em que tal população era praticamente invisível ou não tão relevante. Ainda que São Paulo tenha recebido africanos tardiamente em relação a outras regiões da Colônia, o "esquecimento", compartilhado sobretudo por Ernani Silva Bruno e Mário Neme, responsáveis pelas seções pós-1822, é uma expressão da característica racialmente excludente da sociedade brasileira (e da sua produção científica, evidentemente), que à época da exposição começava a questionar o sentido da sua miscigenação e da suposta ausência de conflitos raciais desde o princípio da colonização. ${ }^{310}$

Trabalhando majoritariamente com a cartografia, Cortesão descreveu, sobretudo na exposição, um percurso em que o conhecimento geográfico acompanhava e atestava o processo de conquista. A valorizada cultura geográfica "Tupi-guarani" da segunda seção se diluía, entretanto, no bandeirante que séculos (e seções) depois estaria de alguma forma visível nas novas formas de apreensão do

\footnotetext{
${ }^{310}$ Menciono especialmente o trabalho de ANDREws, G. R. Negros e brancos em São Paulo (1888-1988). Bauru: EDUSC, 1998. Nesse texto, o brasilianista traça um interessante panorama das relações raciais no Brasil e em São Paulo no pós-abolição, tratando, entre outras coisas, da questão da produção do conhecimento, transformada a partir da década de 1950 pelos estudos de Florestan Fernandes e Roger Bastide, que abriram o caminho para diversos outros trabalhos que se seguiriam nas décadas posteriores, notadamente em torno do Centenário da Abolição da Escravidão, em 1988. Sobre a questão da escravidão e do pós-abolição em São Paulo, menciono igualmente os trabalhos de WiSSENBACH, M. C. C. Sonhos africanos, vivências ladinas: escravos e forros em São Paulo (1850-1880). São Paulo: Hucitec, 1998; SANTOS, C. J. F. Nem tudo era italiano: São Paulo e pobreza (1890-1915). São Paulo: Annablume, 1998.
} 
espaço, como nas séries de mapas a representar a expansão do povoamento da província/estado, o crescimento da mancha urbana da capital ou o avanço das frentes da cafeicultura que, junto das ferrovias e rodovias, colonizavam todo o território paulista. A tônica daquela primeira exposição na Oca foi, substancialmente, uma epopeia da conquista do espaço, construída a partir das relações com a terra, com o conhecimento geográfico. Para além do mencionado fator geográfico que orientaria as suas elaborações, é preciso retomar e acrescentar à perspectiva de Macedo a participação marcante de Jaime Cortesão nos debates fomentados, sobretudo pelo Estado, desde a década de 1930. Como vimos, em torno da identidade nacional e da integração de todo o país, houve uma intensa mobilização de intelectuais, artistas e agentes políticos diversos, trabalho esse do qual Cortesão comungou a partir do Itamaraty e da rede formada por organismos federais.

No sentido impresso aos bandeirantes no contexto das comemorações e recordando a coloração que lhes ofereceu Cortesão, é importante considerar em conjunto os textos que publicou na imprensa sob o título de Introdução à história das bandeiras. Publicados integralmente em Portugal sob esse título, o texto também foi reunido em parte e publicado pela coleção Cultura Geral editada pela Escola de Comunicação e Artes da Universidade de São Paulo (ECA-USP) sob o título Portugueses e Índios no Brasil Colonial, em 1972. ${ }^{311}$ Tal seleção é bastante significativa, tanto pelo título que se deu e que expressa a lógica que orientou os textos escolhidos da série originalmente publicada entre 1947 e 1949, como também pelo conjunto que a publicação forma com os outros números, com textos de professores brasileiros e estrangeiros, em sua maioria vinculados à universidade. A publicação de Cortesão era, de algum modo, inserida no debate acadêmico.

Começando por "Duas raças que acertavam o passo" (OESP, 14 nov. 1947), Cortesão discute as diferenças entre o nativo e o adventício referindo-se às "idades culturais" de ambos os povos e à "cooperação" dos índios na expansão portuguesa

\footnotetext{
${ }^{311}$ A série publicada pela ECA-USP no início da década de 1970 foi composta por 23 títulos, em geral volumes de poucas páginas, como Léxico das Religiões Africanas no Brasil, de Roger Bastide; O Império de Belo Monte, de Maria Isaura Pereira de Queiroz; A Questão Racial Brasileira vista por três professores, de Florestan Fernandes, João Pereira e Oracy Nogueira; A Crise Moderna da Antropologia, de Lévi-Strauss; Antropologia Estrutural, de Lévi-Strauss e Jean Viet; Aculturação e Messianismo entre os índios brasileiros, de Egon Schaden; A cor da pele influencia as ideias?, de Lévi-Strauss; Sociologia do Folclore Brasileiro, de Roger Bastide; Negros no Brasil: religião, medicina e magia, de René Ribeiro e Roger Bastide; Bibliografia sobre o negro brasileiro, de Solange Martins Couceiro; Estudo do Índio Brasileiro/Ontem e Hoje, de Egon Schaden, professor que dirigia a faculdade.
} 
pelo interior do continente. Entre as diferenças e as semelhanças, estaria a distância entre o "instinto" e a "consciência reflexiva"; a "técnica rude de primitivos" e a "ciência, verificada pela experiência"; a "crença supersticiosa, com raízes mergulhadas na bruteza" e as "sublimidades dum amor que abraçava a Natureza e a Humanidade". Identificando as semelhanças pela diferença, Cortesão acabava por definir que portugueses e Tupi compartilhavam traços, mas que uns eram mais humanizados e civilizados do que os outros, que estariam na idade cultural do "instinto": primitiva, bruta, rude. Mesmo compartilhando o diferencial da mobilidade, a cultura geográfica, a capacidade de representar cartograficamente o espaço, foi preciso que ambas as raças acertassem o passo, evidentemente de acordo com a "mais avançada" entre elas. ${ }^{312} \mathrm{O}$ raciocínio é prosseguindo em um texto de junho de 1948, no qual Cortesão apresentava aos leitores do matutino paulistano as bandeiras e os bandeirantes como "produtos da fusão de raças e culturas", termos em que o fenômeno era visto pelo público da exposição de 1954 . O aspecto do "hibridismo cultural", apropriado segundo indica, "dos etnólogos modernos", foi tratado no texto como a base para explicar o mestiço luso-tupi como a expressão de uma "harmonia racial", cujo ponto de partida teria sido a mobilidade física: novamente o autor falava das "duas forças paralelas" que a partir dessa harmonia possibilitada pela mobilidade poderiam "acertar o passo". ${ }^{313}$

É natural que tais textos componham um contínuo com outros sobre o mesmo assunto, como $A$ Fundação de São Paulo ou Raposo Tavares, até porque são resultados de um mesmo trabalho empreendido pelo autor sobre uma mesma documentação, aquela que compunha seus cursos no Itamaraty. Para além da caracterização do processo de "expansão" da colonização com as bandeiras, o autor buscava também definir quem eram os principais atores dessa história, construindo explicações que dessem conta da "cooperação", em uma narrativa que pusesse em segundo plano ou sequer mencionasse eventuais conflitos e resistências.

Nesse sentido, em um texto intitulado "Família luso-tupi" (OESP, 22 jul. 1948), Cortesão refere-se a "muitos dos historiadores contemporâneos" e a "quase todos os antigos cronistas do Brasil" criticando o erro de interpretação ao qual conduziriam os leitores, que acreditariam "que as relações entre os portugueses e os

\footnotetext{
${ }^{312}$ CORTESÃO, J. Portugueses e indios no Brasil colonial. São Paulo: ECA-USP, 1972. (Série Cultura Geral, 22), p. $2 ; 6-7$.

${ }^{313}$ CORTESÃO, J. Op. cit., 1972, p. 9.
} 
índios foram sempre e simplesmente as de senhor tirânico em relação ao escravo, complicadas quando entre indivíduos de sexos diferentes, pela concubinagem desenfreada". Participando da discussão, o historiador diz ser superficial o juízo apresentado nas cartas, relações e crônicas jesuíticas, muito empenhados em criticar a "vida dissoluta dos bandeirantes" e cita como exemplo de historiador que incorrera em semelhante "equívoco" o "compreensivo e penetrante" Alcântara Machado.

Naquela que qualifica como obra-prima da historiografia das bandeiras, Vida e morte do bandeirante, Cortesão discorda da atribuição da poligamia do paulista e do ibérico colonizador à ausência de escrúpulos, de lei ou de consciência coletiva. A esse respeito, Cortesão preferiu afirmar que o colonizador teria se indianizado "na moral ao mesmo tempo que procurou assimilar e assimilou, quer a base da sua economia, quer as suas criações de ordem social e até política e religiosa". ${ }^{314}$ Com essa operação, o autor transferia a hegemonia das relações ao indígena, mas naquilo que era considerado, em grande parte das vezes, condenável. Ao adventício garantiase, ainda, a preponderância do saber.

Entrando, como diz, no "terreno áspero da sociologia", Cortesão recorreu à comparação para tratar ainda desse assunto, mencionando, por exemplo, a família "hispano-guarani no Paraguai". Assunção serviria, então, como ponto de partida para qualquer comparação, considerando-se a sua fundação, anterior à de São Paulo e ainda as "condições mais propícias de mestiçagem" que ofereceria, atestada por documentos que dariam conta da relação poligâmica entre homens espanhóis e mulheres Guarani. Além disso, reitera que "o guarani fez-se aliado do espanhol, em que $[\mathrm{m}]$ reconheceu as mesmas qualidades de bravura guerreira (...) [e] uma superioridade militar que poderia utilizar e utilizou, nas guerras contra seus inimigos (...)". Por outro lado, os "espanhóis tiveram nos guaranis o apoio e a colaboração indispensáveis em tudo, sem esquecer as explorações geográficas e, particularmente, as que visaram as comunicações com os Andes argentíferos e auríferos dos Incas". Fracassando diante da precedência de Pizarro e de outros reveses, o núcleo paraguaio acabaria se proliferando apenas à custa "do seu primeiro fundo poligâmico e híbrido". ${ }^{315}$ A título de conclusão, Cortesão reitera que a alguns historiadores brasileiros faltaria a crítica aos jesuítas e a consideração de uma "realidade americana

${ }_{314}^{314}$ CORTESÃO, J. Op. cit., 1972, p. 17-18.

315 CORTESÃO, J. Op. cit., 1972, p. 19-21. 
própria específica, de base e por consequência, um dos fatos em que se funda a criação, genuinamente brasileira, da nação". ${ }^{316}$

Na coletânea lançada em Portugal em 1975 pela Livros Horizonte, todos os textos de Cortesão da série foram publicados, com o agradecimento feito pela família do autor a Júlio de Mesquita Filho e a João Alves das Neves, respectivamente o diretor e o editor d'O Estado de $S$. Paulo que colaboraram para a recolha dos artigos. A partir do título do primeiro artigo, intitulado "O mistério das Bandeiras", a historiadora Nanci Leonzo analisou também o conjunto de textos, que a seu ver estão organizados do ponto de vista formal em três partes: a da "Geografia geral das Bandeiras"; a dos elementos humanos e culturais que as formaram e lhes deram sentido (o índio, o branco - português, comparado com o espanhol - e o mestiço e a mestiçagem de culturas) e, por fim, a que trata do fenômeno das Bandeiras nas suas relações de oposição (os jesuítas em São Paulo e no Paraguai, no Pará e no Maranhão). ${ }^{317}$ O "mistério" que teria servido como ponto de partida para a exploração de Cortesão remeteria à figura do bandeirante Antonio Raposo Tavares, que para o historiador era vítima de um "estranho silêncio": seu nome e suas ações não figuram nas palavras de cronistas espanhóis e portugueses de seu tempo. Porém, para explicar as "zonas de mistério", não era suficiente "acatar a ideia de que o governo português evitava a divulgação de notícias das cobiçadas terras do Brasil". ${ }^{318}$

Segundo Leonzo e de acordo com o primeiro texto da série de artigos, era essa a grande questão que se buscava solucionar, à luz das ineditíssimas fontes da Coleção De Angelis, bem como seguindo pela senda aberta por Washington Luís, Alcântara Machado, Afonso Taunay, destacados como precursores, e ainda Oliveira Viana, Ellis Júnior, Carvalho Franco, Cassiano Ricardo, Sérgio Buarque de Holanda e Júlio de Mesquita Filho, autores aos quais Cortesão se diz grato, posicionando-se como alguém que se somava ao grupo, na expectativa de proporcionar "novas pesquisas e interpretações". Nesse sentido, o primeiro texto de Cortesão dava amplo destaque à documentação, marcando que além da premissa de que não há história sem documentos, não haveria também documentos sem história, demonstrando o seu

\footnotetext{
316 CORTESÃO, J. Op. cit., 1972, p. 25-26.

${ }^{317}$ LEONZO, N. Op. cit., 1984, p. 118.

${ }^{318}$ LEONZO, N. Op. cit., 1984, p. 117.
} 
papel de não apenas "buscar novos documentos para a história, mas de fazer a história dos documentos publicados". 319

Para além de outras conclusões às quais o autor apresentou, essencialmente expressas na caracterização que fez do fenômeno das bandeiras na exposição de 1954, chamo a atenção especialmente para o sentido que imprimiu Cortesão às relações entre índios e portugueses a partir da zona da aproximação que teriam por conta da "cultura geográfica" de ambos. Nesse sentido, a historiadora Nanci Leonzo indicou importantes caminhos, como por exemplo o da diferenciação que o escritor português fez entre os dois mais duradouros núcleos de mestiçagem e "expansão" territorial da América portuguesa: São Paulo e Belém. Segundo Leonzo,

Em alguns aspectos São Paulo levou vantagem sobre Belém. A fusão de raças é um deles. De acordo com Jaime Cortesão constituiu-se em São Paulo uma "democracia urbana luso-tupi" em que o indígena se tornou, sobretudo, aliado e parente consanguíneo do branco. Ao mameluco de São Paulo, produto da fusão do branco com o tupi, o historiador contrapôs o caboclo de Belém, resultado da mistura do branco com diversas tribos indígenas, para concluir que somente com o primeiro encerra em si a unidade e uma fusão de raça "harmônica e homogênea". ${ }^{320}$

Ora, a mestiçagem ideal para a colonização, e que favoreceria a expansão e a realização da unidade geográfica que existiria, seria entre portugueses e índios Tupi, que pelos motivos que já vimos, se destacariam dos demais grupos. Os mamelucos paulistas estariam, portanto, à frente de outros mestiços, por ser essa uma fusão mais "harmônica e homogênea", dada entre "duas raças que acertavam o passo". Por esse motivo, também, as ações "paulistas" em perspectiva histórica seriam uma importante vitrine do "modo português de estar no mundo", para utilizar a ideia de Freyre à qual Leonzo aproxima Cortesão.

De acordo com a autora, ao português na América, Cortesão "conferiu atributos psicológicos e culturais que explicam e justificam o movimento" das bandeiras. Isso o historiador fez "caminhando através da comparação dos meios e dos tipos sociais", especialmente portugueses e espanhóis. Para Leonzo, o desenvolvimento das ideias de Cortesão fez dele "um verdadeiro apologista do colonizador português", considerando o "acerto de passo" mencionado por ele como "predominantemente subjetivo" e por isso, pouco convincente. ${ }^{321}$

\footnotetext{
${ }^{319}$ CORTESÃO, J. Introdução à história das bandeiras, v. 1. Lisboa: Livros Horizonte, 1975, p. 12-14.

${ }^{320}$ LEONZO, N. Op. cit., 1984, p. 118.

${ }^{321}$ LEONZO, N. Op. cit., 1984, p. 119.
} 
Como fez com a ideia da "família luso-tupi", no intuito de restabelecer o colono português naquelas que seriam as suas virtudes, Cortesão se contrapôs a historiadores locais e de vertentes distintas. Divergindo de Alfredo Ellis Júnior, considerado como um dos partidários da corrente que não enxergava os propósitos políticos oficiais portugueses em bandeirantes como Raposo Tavares, além de equivocado por acreditar que São Paulo estaria totalmente isolada de Portugal durante a regência filipina, Cortesão mereceu uma longa nota de rodapé em $O$ ouro $e$ a Paulistânia, texto de 1948 do historiador paulista. Na ocasião, Ellis Júnior disse que as críticas que lhe haviam sido feitas "eram próprias de um 'ilustre historiador português', que se revestia de 'não fraco colorido patriótico', e que demonstrava ser um 'autêntico reinol contemporâneo'". Refutando-o, o historiador paulista ainda sustentou novamente a sua tese da miséria dos paulistas e contestou a "sólida mediania" defendida por Cortesão. ${ }^{322}$

Sérgio Buarque de Holanda, por seu turno, discordou em Visão do Paraíso (1958) das teses de Cortesão. Sem grandes comentários, o intelectual pontuou que apesar da cartografia quinhentista e seiscentista mostrar "as águas do Amazonas e as do Prata unidas no nascedouro, através de uma grande lagoa central", levando Cortesão a "sugerir ultimamente a ideia de uma 'ilha Brasil', que teria sido concebida entre os portugueses da época sob a forma de mito geopolítico", não seria "fácil, contudo, imaginar de que forma concepções como essa, se é que existiram de fato, poderiam ter tido papel tão considerável na expansão lusitana". ${ }^{323}$ Ainda em outro texto, Sérgio Buarque criticaria não apenas o ponto de vista de Cortesão (sem mencioná-1o) como o de outros historiadores, que se restringiriam ao "coração aventureiro do sertanista" para explicar as bandeiras, uma

vasta e frondosa iconografia, onde tudo, a começar pela indumentária
atribuída a heróis tão assinalados contra a realidade relutante da história,
deve exibi-los a posar sobranceiros para a eternidade, como se tivessem
cuidado de organizar a glória póstuma. A verdade, escondida por essa espécie
de mitologia, é que eles foram constantemente impelidos, mesmo nas grandes
entradas, por exigências de um triste viver cotidiano e caseiro: teimosamente
pelejaram contra a pobreza, e para repará-la, não hesitaram em deslocar-se
sobre espaços cada vez maiores, desafiando as insídias de um mundo
ignorado e talvez inimigo. ${ }^{324}$

${ }^{322}$ LEONZO, N. Op. cit., 1984, p. 123.

${ }^{323}$ HolandA, S. B. Visão do Paraíso: os motivos edênicos do descobrimento e colonização do Brasil. São Paulo: Companhia das Letras, 2010, p. 47; LEONZO, N. Op. cit., 1984, p. 123.

${ }^{324}$ Holanda, S. B. Capitulos de expansão paulista. Org. Laura de Mello e Souza; André Sekkel Cerqueira. São Paulo: Companhia das Letras, 2014, p. 35. Às relações entre Buarque de Holanda e Cortesão caberia um estudo pormenorizado, como por exemplo o de OlIVEIRA, T. K. Cartografias 
Além de afirmar que Cortesão "deixa a saudade da pátria superar a postura científica", Nanci Leonzo também acredita que a entrada do historiador em uma área que estaria, ao menos para alguns, reservada a autores paulistas, não o colocaria a salvo da vigilância e das críticas - antes o oposto. O intelectual português, entretanto, estaria pronto para o debate, desfrutando especialmente de todas as suas credenciais e do acesso privilegiado que tinha a documentos. ${ }^{325}$ À luz do que vimos em torno da exposição e das críticas que mais recebeu, o problema central residiria na disputa em torno da força motriz das bandeiras: o Estado português ou a "livre iniciativa paulista". Em se tratando de um assunto como as bandeiras e os heróis locais (a quem se atribuíam feitos nacionais), em um contexto comemorativo como foi o de 1954 e diante de questões como a integração de uma nação que se buscava moderna, a disputa em torno dos sentidos dessa história/memória não se daria de uma forma que não fosse intensa.

As conclusões de Leonzo sobre o trabalho de Cortesão em torno das bandeiras, dos bandeirantes e do bandeirismo, são que, para além de teses, debates e contribuições do autor para esses assuntos, em grande parte pesou a sua postura de patriota e de franciscano, posturas essas que não invalidariam, evidentemente, o seu percurso. ${ }^{326}$ Nesse sentido, para além dos bons debates travados em torno da história que teria construído os contornos do mapa do Brasil, há também a participação de Cortesão em outro candente assunto nacional, fortemente discutido até o presente:

do "sertão": os mapas sertanistas no discurso histórico de Jaime Cortesão e Sérgio Buarque de Holanda. In: Revista Territórios e Fronteiras, Cuiabá, v. 6, n 2, jul.-dez. 2013. No seu arquivo, Cortesão guardou, por exemplo, um impresso anotado de uma comunicação apresentada pelo historiador paulista em 1948 no Instituto de Administração da Faculdade de Ciências Econômicas e Administrativas da USP. O texto era sobre "Expansão paulista do século XVI e princípios do século XVII", num Seminário de Estudos das Fontes Primárias para a História de São Paulo no século XVI. Além disso, não se pode deixar de lado a presença de Sérgio Buarque no chamado conselho consultivo da Exposição de História, atividade que talvez não tenha exercido - no período, quando era diretor do Museu Paulista, o historiador se ausentou para pesquisar na Itália, onde acabou encontrando Cortesão, trabalhando a serviço da CIVCCSP. Além disso, nem a ele, nem à maioria dos membros do tal conselho, Cortesão registrou agradecimentos em A Fundação de São Paulo.

${ }^{325}$ LEONZO, N. Op. cit., 1984, p. 119; 123-124. Vale relembrar o trabalho de RodRIGUES (2011), quando a autora comenta sobre o narrar a história e ser agente histórico que permeou a produção científica especialmente na primeira metade do século passado.

${ }^{326}$ Leonzo chama Cortesão de "cristão fervoroso". À luz das declarações do autor e dos textos em que lhe renderam homenagens, prefiro optar por chama-lo somente de franciscano. De acordo com SANTOS (1993), Cortesão era agnóstico, mas comungava dos ideais do Franciscanismo, tendo sido sepultado com um hábito daquela ordem. Traços marcantes de sua obra, de que tratarei no próximo tópico, analisam a relevância desse ponto de vista para além do patriótico/nacionalista. 
o da mestiçagem, que de sua parte oferece "curiosas considerações sobre a psicologia do colonizador português". ${ }^{327}$

Antes de passar para essas caracterizações do colonizador, em parte já apresentadas, mas que carecem de interpretações sobre outras dinâmicas que lancem luzes para outros ângulos do assunto, nos interessa aqui pensar especialmente nos sujeitos que se inseriam no meio das contendas entre portugueses e espanhóis, entre bandeirantes e jesuítas, sobretudo nas zonas fronteiriças entre as coroas ibéricas. Sujeitos esses que na escrita de Cortesão se enquadram nos fundamentos "préhistóricos" do país ou que são essencializados em um tipo ideal Tupi, viabilizador da expansão portuguesa por meio de sua mestiçagem com o colono.

Como John Monteiro avaliou, os historiadores brasileiros (ou que trabalharam com a história do Brasil), ao abrirem mão do estudo da história indígena, não reconheceram a historicidade dessas sociedades. Por mais que a ausência de fontes textuais e iconográficas impusesse limites ao trabalho historiográfico, a resistência ao tema, considerado como exclusivo aos antropólogos, iniciou um processo de afastamento que vem de longa data, desde o estabelecimento das linhas mestras da "historiografia nacional", inaugurada por Varnhagen. Para os historiadores "pioneiros" da historiografia brasileira, a ausência de "escrita" - que seria também ausência de história -, bem como o iminente desaparecimento seriam afirmações suficientes para explicar o distanciamento da história indígena. De acordo com Monteiro, permanências desse pensamento estariam, por exemplo, no trato "arqueológico" da questão, como se se tratassem de povos fossilizados, pertencentes a um tempo-espaço sem presente e sem dinâmica. ${ }^{328}$

Nas aproximações ainda recentes entre história e antropologia, Monteiro indica a importância que "a reconfiguração da noção dos direitos indígenas" teve sobre os estudos dessas sociedades. Ao qualificar os direitos indígenas como históricos

\footnotetext{
${ }^{327}$ LEONZO, N. Op. cit., 1984, p. 124.

${ }^{328}$ MONTEIRO, J. M. Tupis, Tapuias e historiadores: estudos de história indígena e do indigenismo. Tese (Livre Docência em Etnologia). Universidade Estadual de Campinas, Campinas, 2001, p. 2-4. Em contraposição, Monteiro cita o quadro de outros países latino-americanos a partir de um estudo de Karen Spalding, que em 1972 identificou um processo em curso na historiografia latino-americana e latino-americanista, que deslocava as atenções dos colonizadores para os colonizados. Na sequência de León-Portilla (1961) e Charles Gibson (1964), uma geração toda buscou "dimensionar, documentar e interpretar a experiência das populações nativas sob o domínio espanhol”. Além disso, essa nova historiografia explorava testemunhos de nativos, crônicas e genealogias escritas por índios e mestiços - testamentos, processos inquisitoriais, investigações criminais etc., manuscritos em línguas nativas e com representações pictóricas elaboradas pelos próprios índios.
} 
- especialmente territoriais - estimulou-se "importantes estudos que buscavam nos documentos coloniais os fundamentos históricos e jurídicos das demandas atuais dos índios ou, pelo menos, dos seus defensores". O autor destacou, nesse sentido, alguns exemplos de dossiês e laudos antropológicos que buscaram sustentar reivindicações de grupos, desde a década de 1980. Mesmo com a emergência de novos sujeitos históricos, Monteiro continuava a destacar a distância que ainda persistia/persiste entre os historiadores e a história indígena. ${ }^{329}$

A categoria "Tupi" por meio da qual Cortesão reuniu os indígenas que "harmonizaram" com o colono português, dotados de excepcional cultura geográfica e culturalmente superiores não foi um instrumento de análise criado pelo historiador português. De acordo com o que Monteiro apresenta, a essencialização em duas categorias foi um artifício usado por colonos diante das dificuldades impostas à descrição da diversidade social desde os litorais. A exemplo de outros quinhentistas contemporâneos seus, Gabriel Soares de Sousa "estabeleceu de início uma grande divisão entre duas categorias maiores, a de Tupi e Tapuia". Outros binômios explicativos se somavam a esse, no afã de "introduzir alguma ordem numa situação às vezes confusa e imprevisível", como cristãos e gentios, povoado e sertão, que por sua vez diziam mais do que respeito ao espaço: delimitavam "dois universos distintos, um ordenado pela lei e pelo governo, o outro livre de tais constrangimentos (...)". ${ }^{330}$

No século XIX, os Tupi faziam parte de um passado distante, no qual haviam dado tudo de si para consolidar a presença portuguesa. A mestiçagem havia os dissolvido em uma "civilização superior", deixando algumas marcas para a posteridade, como na língua e na toponímia signos do seu "heroísmo" e atestados de sua presença na nacionalidade. ${ }^{331}$ Quanto aos Tapuia, lhes restava o polo oposto, ainda que as evidências históricas mostrassem mais ambiguidades do que certezas. O inimigo do colonizador português, empecilho à civilização por resistir, distinguiase do "nobre guerreiro" Tupi que se submeteu à hegemonia portuguesa. Enquanto a opção Tupi significaria "a sua existência enquanto povo", dissolvido no brasileiro, a resistência Tapuia teria garantido a sua sobrevivência naquele século apesar de todas

\footnotetext{
${ }^{329}$ Monteiro, J. M. Op. cit., 2001, p. 5-7.

${ }^{330}$ Monteiro, J. M. Op. cit., 2001, p. 18-20. Glória Kok desenvolveu uma interessante pesquisa que diz respeito ao universo mental e cotidiano dos sertanistas, compreendendo a importância que as expedições tiveram na sociedade paulista setecentista. A autora lança mão da cartografia histórica e aborda com profundidade as culturas indígenas naquele contexto. Cf. KOK, G. O sertão itinerante: expedições da Capitania de São Paulo no século XVIII. São Paulo: Hucitec, 2004.

${ }^{331}$ Monteiro, J. M. Op. cit., 2001, p. 25.
} 
as políticas visando ao seu extermínio. Entretanto, Varnhagen e outros historiadores condenavam os grupos "sobreviventes", obstáculos à civilização. Dessa forma, para muitos historiadores brasileiros, "tornou-se corriqueiro o pressuposto de que o início de história do Brasil significava o fim dos índios". 332

$\mathrm{Na}$ esteira da valorização dos Tupi como matrizes da nacionalidade, um duplo fenômeno se dava em São Paulo: enquanto "homens livres recém-egressos do regime de administração particular ou das aldeias apagavam suas raízes indígenas", as famílias "ilustres" faziam o inverso, buscando remotas raízes nativas de quase quatrocentos anos para consolidarem-se como "povo diferenciado", fruto das primeiras uniões luso-tupis, numa longa genealogia suficiente para diluir os traços indígenas. $^{333}$ Algumas dessas famílias teriam entre seus filhos alguns dos historiadores dedicados à história das bandeiras e que por vezes usaram isso como distintivo. ${ }^{334}$

Nesse quadro, a consideração do ponto de vista de dois autores próximos de Cortesão permite elaborar algumas aproximações entre o historiador português e a produção paulista da história, apesar das críticas que acima foram descritas. De acordo com Della Valle, Afonso Taunay ajudou fortemente na cristalização de um símbolo político de contornos heroicos, em que escravização e extermínio de indígenas são relativizados e postos em comparação com a forma de ação e os valores europeus na mesma época, perspectiva essa que Cortesão adotaria, por exemplo, em Raposo Tavares. Ellis Júnior, por seu turno, lançou mão de teorias raciais para

\footnotetext{
${ }^{332}$ MonteIRo, J. M. Op. cit., 2001, p. 30; 34. A Varnhagen, Monteiro ainda atribui a "condenação perpétua" dos índios à etnografia ou a uma pesada pré-história, restabelecidos somente no século passado por estudos de Alfred Métraux e Florestan Fernandes, ainda fora dos domínios da história. ${ }_{333}$ Monteiro, J. M. Op. cit., 2001, p. 116.

${ }^{334}$ Franco Della Valle, ao analisar a produção da história paulista a partir do caso de Alcântara Machado e Vida e Morte do Bandeirante, identificou as características das disputas que se deram em torno de questões como a linhagem de quem escrevia e dos intuitos da escrita, se qualificada como política, por exemplo. No caso de Alcântara Machado, dada a figura pública do autor e os limites que ela impunha à sua escrita, Della Valle trabalhou com a hipótese original do discurso irônico como forma de crítica. Sem poder fazê-la diretamente, dados os riscos que correria, Alcântara Machado "recorreu à ironia para ressaltar determinadas condutas 'reprováveis' desses 'heróis', tais como a mesquinharia e a escravização dos índios. Ainda de acordo com esse autor, não basta tomar figuras como Taunay e Ellis Júnior como "criadores e propagadores de um mito que interessa ao grupo ao qual pertencem": antes, é necessário levar em conta a relação e a competição entre autores e o que, no momento, estava em jogo na escrita da história paulista. Do interessante ponto de vista da análise de Della Valle, esses historiadores não são "criadores livres para escrever qualquer tipo de versão do passado, nem tampouco meros reprodutores da visão da elite intelectual, política ou cafeeira de São Paulo". Nesse sentido, símbolos de orgulho não podem ter o mesmo sentido para todos de um mesmo grupo. Cf. Della VAlle, F. Vida e morte do bandeirante: Alcântara Machado e a produção da história paulista. Dissertação (Mestrado em História Social), Faculdade de Filosofia, Letras e Ciências Humanas da Universidade de São Paulo, São Paulo, 2015.
} 
"cientificamente" provar a formação e perpetuação de uma "raça paulista", em todos os aspectos diferente do restante do Brasil. Seu elogio da mestiçagem (que excluía negros e incluía novos imigrantes), por exemplo, se utilizaria de categorias até então não utilizadas em relação a bandeiras e bandeirantes, diferenciando-a daquela que havia se dado em outros cantos do país: em São Paulo, ela ocorreu a partir de uma seleta estirpe portuguesa, que apesar de não ser nobre, havia sido favorecida por séculos de miscigenação que haviam constituído uma gente forte, capaz de vencer muitas adversidades. O mameluco, derivado do "português heroico com índios específicos", teve qualidades como a longevidade, a força, o arrojo, a tenacidade. ${ }^{335}$ Ainda que existam pontos em comum entre essa concepção e a de Cortesão, é possível entender o sentido da divergência do historiador paulista com o português, que não autonomizava o mameluco em relação ao português, além de condicionar as suas ações ao poder do Estado, elemento estranho às narrativas que valorizavam a "livre iniciativa paulista".

Considerando a reflexão a partir de Monteiro e as dinâmicas da produção da história paulista em Della Valle e na organização da exposição de 1954, a eleição do Tupi e o silenciamento dos demais grupos para Cortesão revela a sua proximidade com os olhares seletivos da historiografia brasileira em relação aos povos nativos, visto que a categoria Tupi já havia sido escolhida como matriz da nacionalidade justamente pelas tais "alianças e a mestiçagem luso-tupi" que teria consolidado a presença portuguesa na América, criando além disso os primeiros troncos de famílias "brasileiras". ${ }^{336}$ Entretanto, uma grande celeuma se deu em torno dos Guaianá, habitantes da região do campo de Piratininga, quanto à sua filiação: seriam Tapuia ou Tupi? Enquanto os historiadores paulistas, evidentemente, tendiam a vinculá-los aos Tupi, Capistrano de Abreu defendeu a tese de que os povoadores do planalto paulista era, na verdade, Tapuia. Negar aos Guaianá a filiação Tupi significava negar que os paulistas eram descendentes dos heroicos Tupi, bem como significaria questionar a credibilidade de memorialistas e historiadores locais. ${ }^{337}$

De qualquer modo, os primeiros tempos da colonização do planalto paulista pouco correspondiam às versões idealizadas construídas séculos depois. Após o fracasso dos aldeamentos jesuíticos, os colonos tomaram as rédeas da organização

\footnotetext{
${ }^{335}$ Della Valle, F. Op. cit., 2015, p. 66-70.

${ }^{336}$ MonteIro, J. M. Op. cit., 2001, p. 171.

${ }^{337}$ MonTeIRO, J. M. Op. cit., 2001, p. 180-181.
} 
da vila e, contrariando dispositivos legais da Coroa "começaram a favorecer a apropriação direta do trabalhador indígena através de expedições predatórias ao sertão". Ainda que a lei permitisse a escravidão por meio da "guerra justa", os inimigos dos colonos, os "Tapuia”, eram preteridos, buscando os colonos escravizar povos Tupi por conta da sua maior densidade demográfica, pela facilidade de comunicarem-se e pela possibilidade de fazerem alianças. Ainda que constem, até os Setecentos, diversas tentativas de aprisionar grupos Tapuia, os sertanistas sempre retornavam, na maior parte das vezes, com cativos Tupi, frequentemente mulheres e crianças, não sem grande resistência, como de grupos Guaianá e Tupiniquim das cercanias da vila. ${ }^{338}$

Segundo o autor, ao final do primeiro ciclo de contatos entre portugueses e índios, a população nativa havia vivido a desintegração de suas aldeias e a expulsão para regiões relativamente mais distantes, sobrando aos sobreviventes a sujeição a jesuítas e a colonos. Para os portugueses, esse primeiro momento marcou a "liberação" de terras para ocupações futuras, bem como deu o tom de como se organizariam as relações de trabalho naquele núcleo, com base na escravidão indígena e no crescente avanço à medida que as "reservas" se esgotassem. A tendência dominante nas relações entre portugueses e nativos se resumia às questões de alianças e de trocas bem como à disputa pela posse da terra. O contato, "ao desencadear um processo de desintegração entre as sociedades indígenas, acabou, inexoravelmente, desequilibrando as relações iniciais a favor da dominação portuguesa". 339

\section{Uma historiografia das relações: amorabilidade franciscana, luso-tropicalismo e as peculiaridades de uma colonização portuguesa}

A leitura de Cortesão da colonização portuguesa do Brasil pode, em diversos momentos, se aproximar bastante de pontos de vista locais sobre a relação entre colonos e índios. Entretanto, alguns de seus textos - bem como a ponderação que frequentemente se fez a seu respeito - permitem visualizar vestígios que associam a

\footnotetext{
${ }^{338}$ Monteiro, J. M. Negros da terra: índios e bandeirantes nas origens de São Paulo. São Paulo: Companhia das Letras, 1994, p. 51-54.

${ }^{339}$ MONTEIRO, J. M. Op. cit., 1994, p. 55.
} 
sua produção a fontes portuguesas que o teriam alimentado. Como bem salientou Nanci Leonzo, o historiador esteve próximo das principais discussões que se deram no Brasil, entre elas a da mestiçagem. O prisma pelo qual observou tal fenômeno e que o informou para tomar parte do debate brasileiro foi, especialmente, o do Franciscanismo.

Em O humanismo universalista dos portugueses: a síntese histórica e literária (1965), reuniram-se textos de Cortesão publicados em diferentes ocasiões, nos quais literatura e história são mobilizadas para explicar questões relacionadas tanto ao "caráter nacional" e à história de Portugal quanto à colonização empreendida pelos portugueses pelo mundo. Nesse sentido, duas tradições são amplamente estudadas pelo autor: o "espírito de cavalaria" e o Franciscanismo. Do primeiro, ressalta traços como a riqueza da libido, valores como a liberdade individual e a chamada "hombridade", compartilhada com os espanhóis. ${ }^{340}$ Desse espírito, representado nos templários, nas cruzadas e na Reconquista, permaneceria o seu sentido na Ordem de Cristo, a partir da qual, sob a inspiração henriquina, se principiaria a empresa dos descobrimentos. ${ }^{341}$ A "cavalaria andante" tornada navegação estaria inspirada pelo mesmo "espírito de aventura", expressa, por exemplo, pela cartografia da época: na Carta do Brasil de Lopo Homem, de 1519, um dragão como aqueles "que infestavam os bosques nos romances" de cavalaria aparecia no "fundo dos sertões".

Do espírito franciscano, Cortesão acentua o "adoçar a abrir horizontes" que marcaria "tendências democráticas". Além de transformar o cristianismo, o Franciscanismo mudaria a relação com a terra e a natureza e inspirava o proselitismo da religião, levando ideais cristãos a todos os lugares, na Europa, na África e na Ásia. Seu Franciscanismo, no entanto, não se refere unicamente ao santo de Assis. Destaca, especialmente, o lisboeta Fernando de Bulhões, tornado Santo Antônio de Lisboa, considerado um dos maiores oradores daquela confraria, que conferiu aos ensinamentos de Francisco um "certo ardor hispânico". A Santo Antônio, que Cortesão destacou na introdução que fez à Carta de Caminha, o autor atribuiu os traços de "sensibilidade amorável", "inquietação" e "plasticidade cosmopolita dos portugueses". Ao Franciscanismo, Cortesão já havia chamado de a mística dos Descobrimentos, de modo a expressar as "tendências espirituais" que incorporariam

\footnotetext{
${ }^{340}$ CORTESÃO, J. O humanismo universalista dos portugueses: a sintese histórica e literária. Lisboa: Portugália, 1965, p. 14-15.

${ }^{341}$ CORTESÃO, J. Op. cit., 1965, p. 24.
} 
"a expansão geográfica a um pensamento e a uma ética religiosa". Tal fenômeno teria se dado em Portugal devido as suas especificidades étnicas, sociais e históricas. ${ }^{342}$

Os textos que compõem a obra seguem no sentido de elencar os indícios de uma especificidade dos portugueses ao longo de sua história a partir da expansão e do contato com outros povos. Às características já distintas dos portugueses em relação ao restante da Europa e à Espanha, somavam-se outras sínteses: "ao moçarabismo peninsular, acrescentavam-se, em estratificação cosmopolita, um moçafricanismo, um mocindianismo, um moçorientalismo e até um moçotupiguaranismo". Dessa forma, como "Metrópole do Mundo", Portugal teria criado "cidadãos do Mundo", nos quais supostamente haveria "uma consciência nova e unitária da Humanidade". ${ }^{343}$ A obra, em seu conjunto, contemplando inclusive textos apresentados na Anhembi de Paulo Duarte, Cortesão ressaltava a "plasticidade amorável" dos colonizadores portugueses. Tal plasticidade permitiria ao português ao mesmo tempo, dar e receber aos povos com os quais entrariam em contato, sem "alterar o fundo próprio". Tal plasticidade, que "mergulha as raízes no amor, não diminui, mas acrescenta", conservando o caráter. Em referência aos espanhóis, retomou a "hombridade" ibérica, que enquanto "seca e inexorável" levaria ao inquisidor e, no caso português "plástica e amorável”, criaria o apóstolo. É com base nessa dicotomia que o autor compreenderia, enfim, a expansão portuguesa, especialmente em território americano, onde essas duas partes de um mesmo "povo ibérico" se encontrariam. ${ }^{344}$

São essas as ideias que Cortesão imprimiu na série Introdução à história das Bandeiras, especialmente nos textos "D. Quixote e Lusíadas na América" e em "O português, ibérico amoroso". Nesses textos vivificam-se as cores da tolerância étnica, da amorabilidade e da acentuação da virilidade, sendo que no segundo texto - e ambos vinham na sequência de "Duas raças que acertavam o passo" - outro fator mais forte teria aproximado o índio do português: a sexualidade do adventício, à qual as índias não demonstrariam "de modo algum" indiferença. Citando Freyre, Cortesão diz ser acertada a consideração do sociólogo brasileiro a respeito disso. $\mathrm{O}$ autor português ainda retomaria um testemunho, citado por Capistrano de Abreu,

\footnotetext{
${ }^{342}$ CORTESÃo, J. Op. cit., 1965, p. 37-43; 54; 65.

${ }^{343}$ CORTESÃo, J. Op. cit., 1965, p. 100.

${ }^{344}$ CORTESÃO, J. Op. cit., 1965, p. 265-266.
} 
de Montoya, o jesuíta castelhano que frequentemente desqualificava. Conforme diz, o "odioso" texto do inaciano "pretendia fazer da índia a vítima inocente do erotismo desenfreado do invasor", sugerindo ainda que se tomasse Anchieta, "bem mais sereno de alma", que ao tratar do assunto mencionava que as mulheres andavam nuas e que não sabiam "se negar a ninguém". ${ }^{345}$

Recusando, entretanto, ao que seria simplista, Cortesão buscou pelas raízes desses comportamentos, mencionando de Freud às características econômicas, sociais, geográficas e de caráter que teriam moldado os portugueses, não somente na libido mas também na forma de relacionar-se com outros povos, fraternamente. Justificando assim, não nega que os portugueses tenham cometido crimes e erros na América, mas solicita aos que procurem analisar o quadro o vejam nessas condições, sem perder de vista a superioridade que teriam os portugueses, nesse sentido, em relação aos outros povos colonizadores. ${ }^{346}$

Dentre as concepções recorrentes a partir de Freyre, destaca-se a ideia de que o português não seria etnocêntrico e sim cristocêntrico - empenhado em difundir a fé cristã nas terras em que aportou e não a subjugar as outras raças - assunto sobre o qual Cortesão escreveu um comentário ${ }^{347}$, a partir da leitura de Um brasileiro em terras portuguesas. De acordo com o texto, Cortesão dá crédito à afirmação de que os portugueses teriam feito como os árabes: levado a sua fé e se mestiçando com outros povos. O autor ainda lança mão de Jorge Dias para comentar Freyre, destacando uma conferência proferida no Instituto Superior de Estudos Ultramarinos, na qual, inserindo a expansão portuguesa na história da humanidade, discute a "missão" de percorrer os mares e entrar em contato com "as mais desvairadas gentes".

Freyre, destacou Cortesão, elencava a plasticidade, a maleabilidade, a cordialidade e a tolerância étnica como características portuguesas herdadas dos árabes e dos contatos com eles. Jorge Dias mencionava a profusão de povos e culturas fundadoras da índole portuguesa, bem como ressaltava a importância da formação comunitária e as organizações familiares portuguesas, que em muito se assemelhavam às encontradas nos lugares aos quais se deslocaram. ${ }^{348}$

\footnotetext{
${ }^{345}$ CORTESÃo, J. Op. cit., 1975, p. 153.

${ }^{346}$ CORTESÃO, J. Op. cit., 1975, p. 161-162.

${ }^{347}$ CORTESÃO, J. Etnocentrismo e cristocentrismo. Cartas de Portugal. Lisboa, 1958. BNP/ACPC $\mathrm{E} 25 / 35$.

${ }^{348}$ Sobre as comparações de Jorge Dias entre o Portugal das aldeias do norte e as aldeias de Moçambique, ver MACAGNO, L. Luso-tropicalismo e nostalgia etnográfica: Jorge Dias entre Portugal e Moçambique. In: Afro-Ásia, Salvador, n. 28, 2002, p. 97-124.
} 
Depois de destacar estes pontos das teses de Freyre e Dias, Cortesão comentou que o "celtibero" sentia o cristianismo à sua maneira e que, depois de islamizado, sintetizava as civilizações muçulmana e cristã, "direcionando definitivamente a cultura portuguesa". Atribuiu à escola árabe o gênero de vida do comércio de longa distância por terra e mar, as técnicas de navegação, a tolerância étnica e a capacidade de convívio com outros povos, incluindo aí o "amar mulheres de várias raças". No entanto, a raiz românica laicizaria a organização do Estado, diferentemente de como ocorria entre os povos árabes.

Cortesão lança luz para a política de Afonso de Albuquerque, de união de portugueses a "mulheres de outras raças", lembrando que o fato é mais antigo, ligado à colonização de São Tomé e à proposição de D. João II de que a ilha se tornasse uma "escola experimental de novos métodos de colonização, mandando para ali, entre outros colonos, alguns degredados e filhos de judeus", dando-lhes escravos e uma mulher escrava, com a qual povoariam a ilha (alforriando a ela e a sua descendência). Para sustentar esta afirmação, Cortesão citou duas cartas de D. Manuel, de 1515 e 1517.

Em uma ficha, com comentários sobre $O$ mundo que o português criou, Cortesão anota que "dever-se-ia estudar o mundo que criou o português, que o afeiçoou e forneceu elementos à sua criação". Neste sentido, o autor sugere que esta função foi principalmente da África, "que lhe deu o gosto acre da escravidão, esse monstro dissolvente", e do Oriente, "que the acrescentou o sentido da casta, o culto das pompas exteriores e, como consequência, o estilo de vida (...)". Segundo esta leitura, o português a sua cultura é "euro-afro-ásio-americano", e é "no Brasil que se realiza a fusão desses elementos, na sua plenitude (...)". Infelizmente não há uma data que possibilite a localização temporal do texto, cujas afirmações seguem num sentido oposto às leituras e interpretações que sobrevalorizam a ação portuguesa e não dão muita ênfase nos outros povos com os quais entraram em contato ao longo da história da colonização. De qualquer modo, é possível inferir que o texto é bastante anterior, uma vez que as obras estão separadas por mais de dez anos, sendo esta, primeira, de $1940 .^{349}$

\footnotetext{
${ }^{349}$ CORTESÃO, J. [História, II]. s/d. ACPC/BNP, E25/81. Um brasileiro em terras portuguesas, publicada em Portugal em 1955, é um relato subjetivo, com a intenção de ser sociológico, de Freyre, produzido quando, a pedido do governo português, visitou as colônias na África e no Oriente; $O$ mundo que o português criou é a obra que inicia a aproximação entre o sociólogo e o pensamento português,
} 
Observando Freyre pela ótica de Cortesão, notando os dois comentários gerais sobre obras e a referência que ele faz na abertura da coleção Clássicos $e$ Contemporâneos, ficam evidentes as narrativas que valorizam as especificidades do povo português e da colonização empreendida por eles, na qual se destaca a mestiçagem. Além da discussão sobre a hegemonia portuguesa nas relações entre eles e os nativos das regiões em que aportaram, aparece também a necessidade da recuperação de um passado para fortalecer laços entre Portugal e Brasil. A partir desses pontos de vista é também interpretada a história da relação entre colonizador/colonizado, frequentemente adocicada pela aparente ausência de conflitos étnico-raciais, sempre visando à construção de nações de caráter elevado, comungando das bases humanistas e universalistas. Retomando a interpretação de Leonzo a partir dos comentários sobre Freyre aqui apresentados, identificam-se os parentescos do pensamento, possivelmente alimentados pelas mesmas fontes que também deram de beber a Jorge Dias, que encontravam àquela época ressonância no senso comum sobre o caráter nacional.

Se antes de Gilberto Freyre, a mestiçagem era vista no Brasil como um problema a ser resolvido por meio do embranquecimento, após a publicação de Casa Grande \& Senzala (1933) ela se torna um motivo de orgulho, ao ponto de se tornar uma expressão da democracia racial em que se transformara o Brasil. Eliminando os conflitos raciais presentes ou latentes, a mestiçagem, a partir da leitura de Freyre, foi operacionalizada por meio da formulação do luso-tropicalismo, uma aplicação a todo o mundo lusófono das supostas relações raciais brasileiras. Ideologia essa, por sua vez, que foi apropriada e ressignificada pelo salazarismo, sustentando a política colonial portuguesa e defendendo-a das pressões internacionais.

Para Monica Grin (2012), em um texto bastante elucidativo da genealogia dos "mitos de excepcionalidade" do império português e de seus desdobramentos no Brasil, sobretudo nas questões étnico-raciais até os dias de hoje, o tema do "império" para mobilizar o sentimento nacionalista foi crucial da República Portuguesa. O ápice desse sentimento se deu nos anos do Estado Novo português, quando a mística imperial foi disseminada na memória coletiva no fim e após a Segunda Guerra: naquele contexto, "os portugueses seriam portadores de uma missão cristã e

publicada em 1940 e prefaciada em sua primeira edição por Antônio Sérgio, intelectual português do grupo da revista Seara Nova que tinha como amigos tanto Freyre quanto Cortesão. 
civilizacional", diferenciando-se de outros impérios pela sua "genuína vocação para a mestiçagem". 350

Segundo Maria da Conceição Neto (1997), a ideia do "português típico", recorrente na produção daquela época e com ressonâncias no presente, impede de perceber as dimensões históricas do colonialismo e reproduzem muitas vezes um discurso concebido a partir de modelos autoritários e unilaterais, cujas teias ainda precisam ser rompidas. A autora se dedicou a analisar as consequências da apropriação do luso-tropicalismo pela política salazarista, modificando-a para justificar práticas sociais colonialistas sem valorizar demais a mestiçagem, ou ainda policiando-a. O objetivo principal da política estadonovista portuguesa com os pressupostos luso-tropicalistas em relação às suas colônias (e também frente às pressões de organismos internacionais pela autodeterminação dos povos, por exemplo) era o de consolidar mundialmente uma imagem positiva dos portugueses e de suas práticas com outros povos, imagem essa que se opunha às outras potências colonizadoras, que seriam desagregadoras e racialmente intolerantes.

A política colonial do Estado Novo português, "de cariz imperial, nacionalista e centralizadora", sobretudo no período entre 1930 (Ato Colonial) e 1951 (Reforma Constitucional), rompeu com a prática anterior da República portuguesa, descentralizada, e evocou a "vocação e o direito histórico de Portugal à colonização". Desde os anos 1930, a ditadura portuguesa empenhou-se na "criação de uma mística imperial capaz de mobilizar os portugueses no sentido de orgulho e da defesa das colônias", o que foi desenvolvido em diversas frentes, tais como os programas escolares, os meios de comunicação e das grandes exposições. ${ }^{351}$

A justificação maior dessa representação era o Brasil, que aos poucos se tornava mais conhecido no cenário mundial. O país foi tornado exemplo por aqueles portugueses interessados em expressar o êxito da sua ação colonial histórica: portugueses desejosos de participar da relevância que o Brasil vinha ganhando em diversas áreas, seja a exploração de petróleo, seja nas relações internacionais ou ainda na divulgação de suas expressões culturais. Do ponto de vista de Valentim Alexandre (2000), compartilhado por outros historiadores, o período

\footnotetext{
${ }^{350}$ GRIN, M. Mitos de excepcionalidade: versões do Império português e da nação miscigenada brasileira. In: Catroga, F., Hermann, J., Azevedo, F. L. N. (org.). Memória, escrita da história e cultura politica no mundo luso-brasileiro. Rio de Janeiro: Ed. FGV, 2012, p. 294.

${ }^{351}$ CASTELO, C. Novos Brasis em África: desenvolvimento e colonialismo português tardio. In: Varia Historia, Belo Horizonte, v. 30, n. 53, mai.-ago. 2014, p. 510.
} 
convencionalmente chamado por uma parte da historiografia de "terceiro império português", que se estende do reconhecimento da independência do Brasil (1825) às independências das colônias africanas (1975), foi marcado pela tentativa de superação da perda da colônia que era a maior fonte de receitas. Desde então, o país, atravessando sucessivas crises econômicas, sociais e políticas, voltou-se para o continente africano, igualmente disputado por outros imperialistas europeus, servindo-se de suas credenciais de "colonizador exitoso" na América para colocar-se na disputa por recursos naturais e humanos no continente africano, que sustentariam o progresso material europeu no auge da sociedade imperialista e industrial.

Além disso, ao longo da primeira metade do século passado, Portugal se empenhou em demonstrar que as suas práticas, que tinham feito do Brasil uma colônia produtiva e depois um país bem-sucedido, fariam das colônias em território africano "novos Brasis", e não apenas economicamente: nesse sentido, as teses de Freyre corroboravam os pressupostos da histórica política colonial portuguesa, atribuindo-lhe também a criação de uma democracia racial, fruto do modo português de estar no mundo e de se relacionar com povos de outras raças.

Essas elaborações, que se transformaram e transformaram o olhar de Portugal para as terras sob o seu domínio na África desde o século XIX até a dissolução total do império, não foram unânimes e encontraram forte resistência principalmente entre intelectuais africanos, anticolonialistas e independentistas, contestadores do luso-tropicalismo e do seu uso enquanto um álibi para a manutenção do colonialismo sob Salazar (bastante eficaz em lançar mão de recursos diversos para atingir corações e mentes). João Medina (2000), buscando perceber a repercussão do lusotropicalismo e das conjecturas de Freyre sobre todas as áreas de colonização portuguesa, encontrou e discutiu principalmente as interpretações intelectuais africanos, que não apenas contestaram a validade das interpretações freyreanas como também deram a sua versão sobre as práticas do colonialismo luso, isto tudo no contexto da projeção dos movimentos de independência.

Segundo Medina, Mário Pinto de Andrade classificou o luso-tropicalismo como uma "impostura velada" e o denunciou como um álibi para manter a dominação sobre outros povos. Foi o primeiro autor a criticar explicitamente aquela verdadeira ideologia, publicando-se nas páginas da Présence Africaine em 1955, importante revista teórica dos nacionalismos africanos. Andrade também contestou 
a validade da leitura de Freyre para explicar a realidade brasileira, na qual a mestiçagem era propalada como símbolo de tolerância inter-racial, fruto da sexualidade sem moralismos e da não preterição das mulheres indígenas ou africanas pelo colonizador solitário branco. $\mathrm{O}$ autor chama a tese de superficial e, por não conseguir explicar a história brasileira, muito menos poderia explicar outras realidades - com as quais teve um contato restrito e rápido, quando convidado pelo governo português. ${ }^{352}$

Baltasar Lopes e outros escritores cabo-verdianos, bem como Amílcar Cabral, foram bastante taxativos em relação à ideologia apropriada pelo poder colonial português. Além de destacar-lhe os interesses em construir uma imagem positiva frente às Nações Unidas, das práticas políticas empenhadas nas relações com os povos sob domínio colonial, esses autores fizeram questão de demonstrar a invalidade dos pressupostos do sociólogo pernambucano sobretudo para o caso do arquipélago. A principal questionava o fato de que a realidade de Cabo Verde negava o que se propalava sobre o Brasil: nas ilhas, o mulato teria se tornado o elemento estruturante da sociedade, ao passo que no Brasil o mestiço havia sido subjugado pelas estruturas brancas/portuguesas. Em vez de ter sido um mundo criado pelo português, Cabo Verde era o mundo criado pelo mulato, como registrou um poeta local, Gabriel Mariano. ${ }^{353}$

Fica evidente que essa circulação de ideias, encontrando as suas contrapartes, participaram da construção dos nacionalismos independentistas e anticolonialistas na África. Esses intelectuais, encontrando-se também em Portugal e na França onde se congregaram muitos em grupos de estudo e discussão e também em torno da revista Présence Africaine, importante espaço de sociabilidade intelectual - puderam incrementar as ações que se deram também em outras frentes, inclusive na luta armada. A mobilização de experiências e de saberes foi essencial no processo de organização das lutas independentistas, travando um embate igualmente intenso no campo das ideias.

O aparato colonial do Estado português não se deteve, porém, à apropriação e transformação dos postulados de Freyre. Uma série de institutos, centros de estudos e de investigação, museus, arquivos lançaram-se na tarefa de constituir um saber

\footnotetext{
${ }^{352}$ MedinA, J. Gilberto Freyre contestado: o luso-tropicalismo criticado nas colônias portuguesas como álibi colonial do salazarismo. In: Revista USP, São Paulo, n. 45, mar.-mai. 2000, p. 51-54. ${ }^{353}$ MedinA, J. Op. cit., 2000, p. 57-61.
} 
sobre as colônias, nos moldes do que faziam as outras potências imperialistas europeias, como França, Bélgica ou Inglaterra. Como discutiu amplamente Matos (2006), as representações - especialmente as raciais - do império se serviram de uma ampla estrutura, destinada a referendar, cientificamente (como mandavam as regras do jogo desde o século anterior), as práticas políticas e sociais do imperialismocolonialismo dos séculos XIX-XX. Se em outros tempos a religião detinha a hegemonia na legitimação dos impérios, nos tempos modernos a ciência vinha a ocupar este papel, nomeadamente com a projeção de saberes como a Antropologia e a Etnografia.

Para ficarmos em um caso, em 1955 o Ministério do Ultramar criou o Centro de Estudos Históricos Ultramarinos (CEHU), cuja atividade se debruçava integralmente sobre todas as áreas colonizadas por Portugal no presente e no passado. O CEHU convidou Jaime Cortesão - demonstrando "alto apreço" ao seu papel de historiador - para tornar-se um correspondente, promovendo o intercâmbio de documentos do interesse da história portuguesa colonial, microfilmados ou fotocopiados, entre instituições brasileiras e portuguesas. ${ }^{354}$

O objetivo do novo órgão era o de sistematizar a documentação referente à história da colonização junto a arquivos, bibliotecas e instituições similares, fomentando dessa forma a produção de um conhecimento histórico sob a gestão do Estado. De acordo com o decreto de criação, anexado à correspondência encaminhada a Cortesão, o CEHU pretendia preencher a lacuna de um instituto que organizasse a pesquisa histórica sobre o ultramar, aglutinando os esforços de vários pesquisadores e instituições em torno do assunto: unem-se no projeto as Juntas de Investigação sobre o Ultramar, o Instituto Superior de Estudos Ultramarinos, o Arquivo Histórico Ultramarino, a Filmoteca Ultramarina entre outros. Suas funções legais eram as de "coordenar, estimular e promover investigações históricas relativas à ação dos portugueses no descobrimento, aproveitamento e civilização de territórios de além-mar" e "recolher as fontes históricas que possam concorrer para aquelas investigações e auxiliar a conservação e divulgação delas". 355

A partir da documentação de Cortesão, foi possível identificar algumas das atividades desempenhadas pelo autor no âmbito do CEHU, nomeadamente o envio

\footnotetext{
${ }^{354}$ FARIA, A., Embaixador. Correspondência [cópia de telegrama]; anexo Diário do Governo, 24 fev. 1955, p. 145-146. [Lisboa], 1955. BNP/ACPC E25/449.

${ }^{355}$ Decreto-lei 40.070/1955, publicado no Diário do Governo em 24 fev. 1955, p. 145-146.
} 
de microfilmes da Biblioteca Nacional do Rio de Janeiro - instituição para a qual trabalhou durante quase toda a sua estada no Brasil - para a Biblioteca Nacional de Portugal, mediante a remessa de outros, que fossem do interesse dos arquivos brasileiros. Em uma entrevista concedida ao Diário de Lisboa, Cortesão comentou sobre o envio de um microfilme, de propriedade do Ministério da Educação brasileiro, o qual trazia um relatório seiscentista de um missionário português no Monomotapa, atestando, de acordo com as suas palavras, que os portugueses "já frequentavam com fins comerciais o Lago Niassa, assunto de grande interesse para a História e Geografia dos Portugueses e para a matéria do conhecimento do continente africano". ${ }^{356}$ A relação apresenta, portanto, certa ambivalência ${ }^{357}$ do autor, que embora opositor político do salazarismo, convergia no aspecto dos usos do conhecimento histórico em prol da valorização do passado português, mobilizado para fortalecer a autoestima - ufanista - e consequentemente o nacionalismo, que dependia da manutenção de seu caráter colonial imemorial.

Também nos documentos guardados por Cortesão, de interesse direto dessa reflexão, são encontrados diversos recortes de imprensa, dentre os quais de seus textos publicados em periódicos brasileiros, angolanos, moçambicanos e portugueses. A maior parte dos textos se repete, publicados em mais de um jornal, sendo que os dois deles, na imprensa africana, aparecem como integrantes da série "Velhos erros, novas correções", que foi inicialmente publicada pelos jornais brasileiros. São textos de história que têm como objetivo aparente a superação de sensos comuns e a publicidade de sujeitos e acontecimentos.

O jornal A Província de Angola (26 fev. 1959), vem com um trecho na primeira página, intitulado Causas da Independência de Portugal e da formação portuguesa do Brasil, diagramado ao lado da chamada para a reportagem Promover a colonização portuguesa e educar a população indígena são objetivos fundamentais em Angola para se obter suficiente infraestrutura - declarou o prof. Dr. Marcello Caetano ao dissertar sobre Planificação Econômica. Além disso, a capa traz o texto $O$ amor ao trabalho e a vincada honestidade

\footnotetext{
356 CoRtesão, J. Fala Jaime Cortesão [Entrevista]. In: Diário de Lisboa, Lisboa, 25 jan. 1955. BNP/ACPC E25/1999.

${ }^{357}$ Estas ambivalências dizem respeito às convergências entre autores e a cultura da qual pertencem. No caso, aproprio-me aqui da reflexão proposta por Said em relação à produção literária que traz em si traços do imperialismo/colonialismo e da relação com o outro: mesmo que não sejam autores "a serviço" do sistema, é impossível separá-los do conjunto de saberes e de práticas que compõem a sua formação cultural, social, política etc. cf. SAID, E. Cultura e Imperialismo. São Paulo: Companhia das Letras, 2011.
} 
são características essenciais da colônia portuguesa da Venezuela - disse o prof. Paulo Cunha (acompanha foto) ao regressar de Caracas. O texto de Cortesão ressalta as características portuguesas na formação do Brasil e do papel que a exploração do continente sulamericano teve para a restauração da independência portuguesa em 1640. Outro jornal, Notícias de Lourenço Marques (15 set. 1959), de Moçambique, trouxe o mesmo texto, que totalmente recortado, não aparece no contexto da diagramação. ${ }^{358}$

Chamo a atenção para as chamadas e reportagens que compõem a página na qual o texto de Cortesão aparece para apontar para uma possibilidade da recepção de sua escrita: o elogio histórico da colonização portuguesa do Brasil vai de encontro às falas de Marcello Caetano e Paulo Cunha, que naquele ano de 1959, davam relevo às práticas portuguesas fora da metrópole naquele contexto. À luz do passado, os jornais destinados às colônias portuguesas em Moçambique e Angola, pareciam chamá-los à ação dentro do contexto em que se encontravam, em nome de um caráter português que não tinha fronteiras temporais, nem territoriais.

$\mathrm{Na}$ mesma página em que se reportava a inauguração da Exposição de História de São Paulo, o jornal dos Mesquita apresentava a cobertura da visita oficial do mesmo ministro Paulo Cunha, que tinha cortado a fita de abertura da mostra. Em coletiva à imprensa, o ministro de Estado comentou a visita de representantes do prefeito e do governador de São Paulo "durante as comemorações levadas a cabo na Capital portuguesa". Dizia Cunha que o que se havia realizado em Lisboa "foi já uma antevisão da Exposição Histórica de São Paulo", pois o país havia enviado o que de melhor e mais precioso possui", entre eles o grandioso documento da Carta de Pero Vaz de Caminha. Demonstrando interesse em visitar mais demoradamente o Brasil, fala sobre as questões diplomáticas com a União Indiana, e os "indoportugueses" de Nova Goa. Prosseguindo sobre o assunto, dizia Paulo Cunha que seu país "não faz colonialismo", justificando que "em todos os territórios da nação portuguesa não existe dominação de uma minoria sobre uma maioria". Como exemplo, cita o ministro que "todos são iguais perante a lei", independentemente "crença", de "cor" e de "raça", motivo pelo qual Portugal tinha obtido apoio de todos os países. Ademais, demonstra que colonizados seriam os indo-portugueses caso fossem anexados pela União Indiana, onde vigoraria a estratificação que existe na

358 CORTESÃO, J. Velhos erros, novas correções: recortes de imprensa. Várias datas, vários locais. $\mathrm{BNP} / \mathrm{ACPC} \mathrm{E} 25 / 74$. 
sociedade indiana, a despeito da inexistência de párias no Estado da Índia Portuguesa. ${ }^{359}$

Em Portugal, celebrando a grandiosidade da data do quarto centenário de São Paulo, solenidades aconteceram em Lisboa e em Coimbra. No Palácio Galveias, no Campo Pequeno, na capital portuguesa, foi aberta na data-símbolo da comemoração uma Exposição Histórica, a mesma mencionada pelo ministro Paulo Cunha. Acompanhariam ainda nessas cidades inaugurações, sessões em instituições como a Academia de Ciências e a Universidade de Lisboa, bem como na Universidade de Coimbra. Em Luanda, a passagem da data foi celebrada com diversos eventos entre 25 e 31 de janeiro, com a presença de Damião Peres, do ministro Paulo Cunha, de Orlando Ribeiro, Gustavo Cordeiro Ramos, entre outros. Um selo comemorativo seria lançado ao longo daquele 1954 com a alusão ao padre Manuel da Nóbrega. ${ }^{360}$ Dessa forma, a ex-metrópole poderia, não apenas por meio de seu ilustre historiador, tornado luso-brasileiro por força das circunstâncias, Jaime Cortesão, participar da celebração da mameluca fundação na América do Sul: divergências à parte, convergiam cada qual a seu modo, no elogio da ação portuguesa no mundo.

\section{História, mediações culturais e lusofonias}

Agostinho da Silva, intelectual português também exilado no Brasil, casado com uma das filhas de Jaime Cortesão e vivendo ininterruptamente no país entre 1947 e 1969, onde circulou por diversas instituições universitárias e governamentais, além de ser o criador do Centro de Estudos Afro-Orientais da Universidade Federal da Bahia, é uma personalidade que também ajuda a compreender outras das permanências do pensamento de Cortesão, visto que ambos comungavam de um muito semelhante programa de ação. Falecido em meados dos anos 1990, foi a partir de caminhos abertos por Agostinho da Silva, que se lançaram as bases para a criação da Comunidade dos Países de Língua Portuguesa - a CPLP, que, entre outras coisas, buscava fortalecer os laços interculturais do grupo de países lusófonos, formado por Portugal e pelos Estados que se constituíram a partir do colonialismo português.

\footnotetext{
${ }^{359}$ Expressivas homenagens prestadas ao ministro português do Exterior. In: O Estado de S. Paulo, São Paulo, 14 set. 1954, p. 12.

${ }^{360}$ Comemorações em Portugal. In: O Estado de S. Paulo, São Paulo, 24 jan. 1954, p. 8.
} 
Ao discutir o trabalho de Agostinho da Silva na Exposição de História, Gilson de Oliveira Júnior (2010), destacou, além das características da direção indicada pelo organizador geral, a forma como o filósofo português apreendeu a narrativa da colonização do Brasil construída por Cortesão, próximo de quem trabalhou também no âmbito do Itamaraty:

Foi também muito importante para mim a Exposição Histórica e o trabalho do Itamaraty, porque me deram a conhecer como é que Portugal tinha realmente construído o Brasil. Eu nunca tinha percebido como fora a construção do Brasil; a história que se dava em Portugal nunca incluiu aquele país, a não ser dizendo que Pedro Álvares Cabral tinha feito a sua descoberta e que o Brasil se tinha tornado independente em 1822. Como é que aquilo tinha feito e o que sucedera por lá quando afinal o Brasil era parte de Portugal, não se dava de jeito nenhum. Fui aprender isso no próprio Brasil. ${ }^{361}$

Como os destaques de Oliveira Júnior denotam, a experiência do exílio no Brasil para Agostinho da Silva, com quem Cortesão compartilhava laços de origem e de parentesco, além de afinidades intelectuais, havia transformado as concepções sobre a própria história portuguesa. Essas afirmações, como Gilson Brandão de Oliveira Júnior tratou ao longo de seu trabalho, têm o seu peso dentro das iniciativas empreendidas por Agostinho da Silva e reverberaram nas áreas a que se dedicou. Ao considerar especialmente o Itamaraty e a exposição, espaços em que trabalhou como assistente do sogro, Silva sugere um caminho interessante para apreender os desdobramentos do pensamento do historiador, situando o lugar que Cortesão ocupou nos debates sobre a identidade nacional brasileira e por meio de quais instrumentos o fez maiormente. Nesse sentido, podem ser entendidas como continuidades de um programa de ação - como se referia Cortesão às suas atividades no Brasil - as ações de Agostinho da Silva, com quem partilhava pontos de vista em relação ao Brasil, a Portugal e a um mundo lusófono.

De acordo com a análise realizada por Oliveira Júnior, Agostinho da Silva reconhecia o "espírito expansionista" português nos colonos que se estabeleceram na América do Sul, salientando a nacionalidade e a procedência regional - portugueses alentejanos ou das ilhas, de matrizes alentejanas e algarvias - de Raposo Tavares e dos casais que formariam cidades ao sul do Brasil. Tal ponto de vista se expressou em uma de suas obras, no final da década de 1950, na qual embora o filósofo "tenha assumido o papel predominante de Portugal na caracterização da sua missão", a

\footnotetext{
${ }^{361}$ Silva, A. apud OliveIRA JÚnIOR, G. B. Op. cit., 2010, p. 82. Grifos de Oliveira Jr.
} 
efetivação do Quinto Império - o português, na sequência dos outros grandes da antiguidade -, também atribuía a todos os lusófonos (colonizados) a parte que lhes cabia nesse processo de "renovação cultural no mundo", dando ao Brasil um papel especial, pois nele viveria a mais acabada herança do que teria sido o "Reino da Inteligência". Complementando o quadro que já vimos anteriormente, era interessante tanto a Portugal quanto ao Brasil essa ideia de formar uma "comunidade", visto que do lado brasileiro seria uma forma de aproximar-se da Europa, de questões mundiais de maneira ativa em um contexto de reorganização global no contexto do pós-guerra, ao passo que para Portugal seria uma importante possibilidade de mostrar ao mundo o exemplo de seu modo diferenciado de colonizar, credenciando-o em suas atividades em solo africano. No pensamento de Agostinho da Silva, por meio da língua, da comunidade de cultura - forma a partir da qual Cortesão também apreendia as sociedades ao redor do mundo - promoverse-iam "radicais alterações na ordem vigente", expandindo assim o sentido dos antigos anseios dos seareiros quanto ao papel de Portugal - e de sua comunidade - no mundo. Para a África, sobretudo, deveriam se voltar os esforços da comunidade lusobrasileira por ele pensada, em termos muito próximos daqueles elaborados no seio do regime ditatorial português (ao qual também se opunha) para as colônias. Segundo a interessante interpretação de Oliveira Júnior, tais pontos de vista revelavam duas formas de apreender a lusofonia e o seu papel aglutinador: uma horizontal (entre Portugal e Brasil) e uma vertical (da comunidade luso-brasileira sobre as então colônias lusófonas na África). ${ }^{362}$

No contexto do que se produzia sobre o passado e o presente do colonialismo português, Omar Thomaz realizou um trabalho que contempla algumas das principais perspectivas que busquei analisar ao longo deste texto, lançando luz especialmente sobre as inter-relações entre experiências mais ou menos aproximadas pelo que Agostinho, Cortesão e outros intelectuais luso-brasileiros, sobretudo,

\footnotetext{
${ }^{362}$ OliveirA JúNIOR, G. B. Op. cit., 2010, p. 98-104; 109-110. No papel de organizador do Centro de Estudos Afro Orientais da Universidade Federal da Bahia, o autor destaca de que forma Agostinho da Silva contribuiu para definir a orientação dos estudos sobre a África no Brasil, os quais seriam fortemente influenciados pelo chamado nagocentrismo, ponto de vista que valorizaria os povos da região correspondente à Nigéria em relação aos demais povos africanos. Em outros termos e guardadas as devidas proporções, poderíamos pensar num paralelo entre essa e a conformação de um tupicentrismo, seguindo os passos do que John Monteiro indicou e interpretando, por exemplo, o que se expressou na Exposição de História de São Paulo. Ambas as concepções, elegendo um representante supostamente mais "evoluído", essencializado a partir de um olhar eurocêntrico, determinariam a produção do conhecimento e até a formulação de políticas para essas populações.
} 
compreendiam como elo luso, mas lidas de um outro ponto de vista. Os ecos do Atlântico Sul que Thomaz faz escutar concentram-se no "período áureo da ideia de império em Portugal", nas primeiras décadas do salazarismo, sobretudo entre o Ato Colonial de 1930, a institucionalização do Estado Novo, em 1933 e o período próximo à Exposição do Mundo Português, de $1940 .{ }^{363}$ Mobilizando interpretações sobre a ação colonizadora portuguesa através dos tempos, construía-se, a partir das iniciativas do regime instaurado, a imagem - sobretudo racial - daquele império de muitas gentes, que supostamente não praticaria a predação e a desagregação que outras potências realizariam. $\mathrm{O}$ Ato Colonial, "produto e produtor de representações", demandou do país e dos portugueses uma

produção cultural à altura de um moderno império colonial, mas, sobretudo, uma reflexão sobre o lugar de Portugal no mundo e sua missão de possuir e colonizar territórios distantes e incorporar plenamente na "lusa grei" gentes exóticas que, na realidade, seriam verdadeiros portugueses. (...) [A] experiência portuguesa no Brasil e seus "fabulosos ganhos", [eram] transformados agora em virtudes inatacáveis. ${ }^{364}$

Mediado pela cultura, o conhecimento que se produziu sobre o passado colonial tornou-se, nesse sentido, ele também uma forma de dominação, por meio da qual, discursivamente, se pensava e se falava sobre indivíduos e territórios subjugados, afirmando o poder colonial. A "alta cultura" que seria produzida, estaria no nível correspondente à importância do império colonial, representado sobretudo na Sociedade de Geografia de Lisboa. No periódico O Mundo Português, por exemplo, Thomaz cita o certo "consenso" que existia no debate, na década de 1930, a respeito da importância das colônias, da "tradição assimilacionista" de Portugal e da necessidade do país explorar de forma adequada os espaços que colonizava, produzindo e acumulando saberes que encontrassem espaço em instituições como sociedades, museus (ou exposições, como as diversas realizadas em Portugal entre as décadas de 1930 e 1940) e escolas. ${ }^{365}$

O mundo português, notável expressão do nacionalismo intimamente vinculado ao colonialismo e ao império, foi vigorosamente celebrado entre os anos 1930 e 1940, convidando quem quisesse para apreende-lo intelectualmente e pela sensibilidade. Mesmo as cidades, como Lisboa, Porto e Coimbra, sofreram profundas intervenções

\footnotetext{
363 ThOMAZ, O. R. Op. cit., 2002, p. 21.

364 Thomaz, O. R. Op. cit., 2002, p. 80.

365 Thomaz, O. R. Op. cit., 2002, p. 83-84.
} 
urbanas, que estivam de acordo com essa mentalidade: Lisboa, enquanto "capital do império", tornou-se o foco de um projeto que "chamou à ação arquitetos, urbanistas, artistas e políticos". Enquanto as exposições eram uma forma de atingir a sensibilidade do público em geral, recorrendo aos moldes utilizados nas exposições universais e coloniais, congressos serviram de espaço de discussão sobre o que dizia respeito a esse mundo. Mendes Corrêa, cujas atividades também são discutidas no trabalho de Patrícia Matos (2006), no qual a autora discute de maneira bastante aprofundada as representações raciais no império português, apontou nesses congressos a necessidade de avaliar adequadamente o "lugar do mestiço nas colônias portuguesas", considerando insuficiente o que já se havia produzido sobre o assunto no Brasil. Ainda sem conclusões definitivas sobre vantagens nacionais e humanas trazidas pela mestiçagem, o Brasil permanecia como um objeto de estudo preferido para se pensar a respeito desse assunto, mirando-se sobretudo nos "bons exemplos" que seriam os mamelucos das bandeiras paulistas, sem, no entanto, utilizar o caso como exemplo a ser seguido. ${ }^{366}$

Seguindo a reflexão de Thomaz, e observando os frutos que vieram das exposições e feiras universais/internacionais e de suas seções coloniais, são marcantes os museus coloniais, que depois se tornaram de antropologia e etnografia. Esses espaços são demonstrativos do evidente "esforço de classificação e ordenação do mundo não-ocidental", ou ainda "Templos do Império", na pontual síntese de Annie Coombes apresentada então pelo autor. Por meio dessas instituições, além da literatura e de outras formas de arte, inventam-se a África e os africanos, o Oriente e os orientais. No museu ou nas exposições que se organizaram em Portugal, escancarava-se a hierarquização e a sistematização operada pelo império. Com o intuito de preservar o "testemunho material de povos condenados à uniformidade da experiência do gênero humano", museus coloniais e exposições como as organizadas como expressões do mundo português, definiam, num gesto colonizador, o caminho que os povos marchariam, inevitavelmente, rumo a um progresso. ${ }^{367}$

Dentro desse contexto, é representativo pensar em um percurso que, alguns anos antes de Portugal se empenhar na realização da mostra do centenário paulistano, havia sido trilhado no caminho inverso, com a participação brasileira em

\footnotetext{
366 THOMAZ, O. R. Op. cit., 2002, p. 126-127; 132-133.

367 THOMAZ, O. R. Op. cit., 2002, p. 205.
} 
uma exposição portuguesa. Suprema criação portuguesa do ponto de vista de Salazar, o Brasil teve o seu pavilhão da grandiosa exposição do mundo português de 1940. Na ocasião, o presidente do outro Estado Novo, Getúlio Vargas, nomeou uma comissão especial, à qual foi dada a tarefa de mostrar o Brasil no conjunto desse mundo. Entre as muitas peças exibidas, O Café, de Portinari, causou especial impacto, tanto negativo - considerado subversivo - quanto positivo, animando novas gerações de modernistas portugueses, a essa altura já informados pelo modernismo brasileiro e pelo muralismo mexicano. Enfatizando a modernidade e o dinamismo, o Pavilhão do Brasil mostrou também peças da cultura material afro-brasileira, como bonecas e bonecos com vestimentas de orixás, exibidos nos primeiros dias da exposição ao lado de peças indígenas. Recebidas com horror por parte da delegação brasileira, entretanto, foram excluídas da mostra. Nas salas dedicadas a apresentar os Portugueses no Mundo, em pavilhão próprio, o Brasil era descrito na síntese lusoindígena. De acordo com Thomaz, "a ideologia da mestiçagem e mesmo o projeto incorporador do Brasil de Getúlio acusam um dinamismo estranho às tradições paralisantes impulsionadas pelo salazarismo". Nesse aspecto, O Café de Portinari, longe de uma "romântica e estática" representação da vida camponesa, não foi mal recebido por acaso: a aldeia portuguesa representa, segundo o autor, o contrário de qualquer movimento ou história. ${ }^{368}$

À luz dessas reflexões, o que proponho aqui, como ponto de partida e não de chegada, é uma análise entre tantas as possibilidades que se apresentam a partir do entendimento do contexto em que se forjaram interpretações e se produziu conhecimento sobre os povos aos quais hoje chamamos de tradicionais, nativos, indígenas, sejam eles africanos, americanos, asiáticos. Nesse sentido, perceber como a exposição que comemorou a história quadricentenária de São Paulo, cidade que se afirmava como o mais importante centro cultural do país, permite identificar esses eventos culturais, inseridos em contextos festivos, estratégias de divulgação de certos conhecimentos cientificos produzidos e tentativas de propagar um discurso hierarquizante, eurocêntrico, sobre toda a vivência histórica da colonização. Ao ignorar saberes produzidos por grupos que não os institucionalmente dominantes, bem como ao escamotear seu patrimônio, exposições e outros tipos de mediações culturais entre um público e um determinado saber acabam por fortalecer sensos

${ }^{368}$ ThOMAZ, O. R. Op. cit., 2002, p. 258-261. 
comuns ou ainda servir de instrumento, intencional ou não, de estratégias não autonomizantes e democratizantes das nossas sociedades, marcadas pela tensa história da colonização.

Considerando os pontos em comum que existem entre os países hoje independentes que adotaram a língua portuguesa como oficial (sem entrar no mérito de como se deu esse processo de adoção), em vista desses problemas que ora observamos, faz-se necessário observar as possibilidades que esse mundo tornado português teria, em conjunto, de pensar formas de trazer para o centro do debate os pressupostos que se firmaram como ciência e como cultura, oferecendo aos próprios integrantes dessa virtual comunidade uma percepção que dê conta de apresenta-la em toda a sua complexidade e diversidade. Em outras palavras, uma descolonização do olhar sobre as sociedades e as expressões culturais historicamente subalternizadas se faz urgente, visando à superação das práticas sociais e da produção do conhecimento colonial/colonizado que as legitimou.

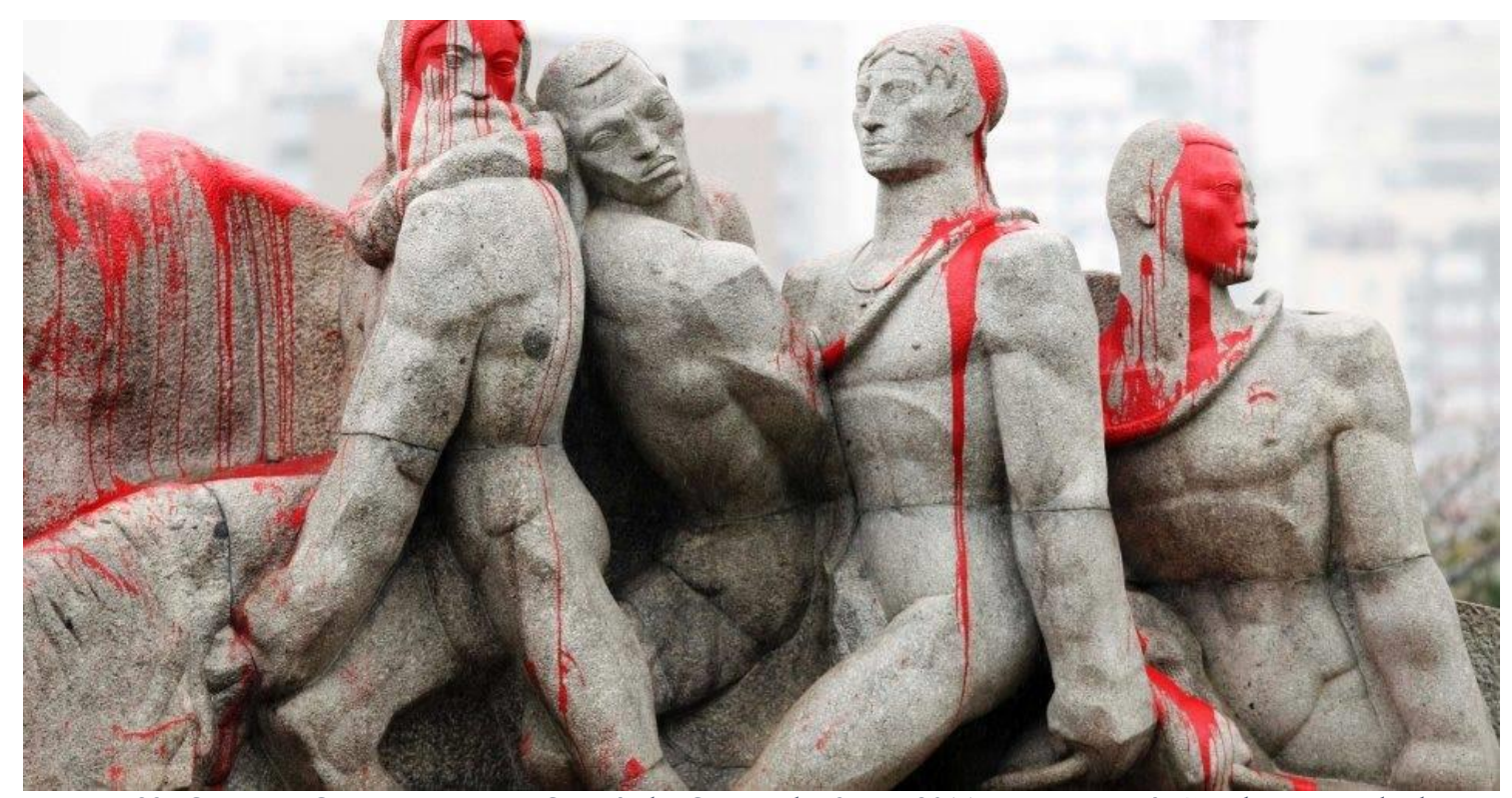

Imagem 23. Comissão Guarani Yvyrupa. Sem título. São Paulo, 3 out. 2014. Monumento às Bandeiras tingido de tinta vermelha no dia seguinte. Disponivel em <http://campanhaguaranisp.yvyrupa.org.br/?page_id=254>. Acesso em 28 jul. 2015.

Concluo esta proposta de reflexão apresentando uma fotografia, feita após uma manifestação de grupos indígenas na cidade de São Paulo no ano de 2013. Na imagem (23), o Monumento às Bandeiras, homenagem aos sertanistas do passado, aparece tingido de tinta vermelha, derramada sobre os corpos humanos esculpidos por Brecheret. Reclamando, de alguma forma, o registro de sua leitura no patrimônio erigido em local privilegiado, grupos indígenas e apoiadores buscaram com a 
intervenção artística/política registrar um viés que o heroísmo construído não contemplaria. A cor, alusão ao sangue, expressava as mortes no passado e no presente pela ação desagregadora que permitiu e permite o avanço de um modelo de progresso e de sociedade sobre outros, como os indígenas do território brasileiro, destinados a figurarem como de um povo sem direito à diversidade e à historicidade.

\section{CONSIDERAÇÕES FINAIS}

Ao longo do ano de 1984, por iniciativa da Academia Lusíada de Ciências, Letras e Artes, apoiada pela Academia Paulista de História, pela Biblioteca Municipal Mário de Andrade, pelo Centro Cultural São Paulo e por outras instituições e espaços, foram promovidos diversos eventos em homenagem a Jaime Cortesão pelo Brasil e especialmente em São Paulo, celebrando o centenário de seu nascimento. Das palestras, conferências, textos escritos por pessoas que haviam sido próximas ao historiador ou que se dedicaram a estudar os seus trabalhos e atividades, foi publicado um volume especial da revista Comunidades de Língua Portuguesa, edição em que se celebraria também o intercâmbio entre Portugal e Brasil. ${ }^{369}$

Entre os autores, estavam Ernani Silva Bruno e Hélio Damante, que trabalharam na organização da exposição de São Paulo. Nesses textos é possível identificar o impacto da presença de Cortesão no Brasil, como por exemplo no escrito por Damante, que se refere ao intelectual como um "historiador de dois povos". O jornalista recorda um episódio vivido com Cortesão, quando, a serviço da Comissão do IV Centenário, estavam a caminho do porto de Santos para receber encomendas para a Exposição. Damante comenta que, ao parar em um ponto da Via Anchieta, Cortesão e sua esposa, acompanhados do jornalista e do motorista, observam do alto a Baixada Santista - e o português chamou a atenção de todos sobre o lagamar, apontando sobre os significados daquele espaço, daquela região:

[I]sto significa em termos de perspectiva histórica e de predestinação geográfica (...) os navegantes e seu imenso lastro de civilização ocidental e cristã (...). Significa as trilhas indígenas, as primeiras entradas e engenhos, os missionários, os cruzamentos raciais, que logo o sangue negro pigmentaria para sempre, os piratas oficiais da Inglaterra e da Holanda, a imigração

${ }^{369}$ Trata-se de Comunidades de Lingua Portuguesa: Revista semestral de Cultura. Edição Especial Intercâmbio Portugal-Brasil: Jaime Cortesão e o Brasil. São Paulo, n. 5, 1985. 
estrangeira e a consumação do destino de São Paulo como capital geográfica do Brasil. ${ }^{370}$

A tese sobre a qual Cortesão tinha trabalhado em $A$ Fundação de São Paulo, e que havia informado substancialmente a organização da exposição de 1954, parece ter convencido intelectual e sentimentalmente o historiador e jornalista paulista, que em tons efusivos lembrou o "velho e querido mestre". Lembrando-se de Cortesão, Damante deixou visível a apreensão que teve ao trabalhar perto do historiador lusobrasileiro. Narrando uma América virgem, pura e edênica a ser então povoada pelos europeus, Damante ressaltou as relações entre portugueses e indígenas e africanos, a partir da qual teria sido gerada uma mestiçagem que ao menos tinha nos dado "as nossas democracias raciais". Dos sujeitos próximos a Cortesão durante a organização da Exposição, talvez Damante fosse o único a registrar que os "ciúmes" que o rondavam e os "orçamentos apertados" eram os seus maiores inimigos. Ciúme este que reverbera no parágrafo em que menciona a "tempestade" desencadeada em São Paulo pelo simples anúncio do nome do organizador, identificada especialmente nas "várias correntes da historiografia paulista" que se investiam, como declaravam, não contra o historiador português, mas sim contra os "seus critérios". Das meiaspalavras de Damante, entende-se que parte dessas brigas estão relacionadas à questão de Anchieta (um espanhol, dito de passagem), que teve o seu papel redimensionado, bem aquém do que a memória histórica paulista lhe conferia e a Manuel da Nóbrega (um português, lembra), o protagonismo na fundação, trabalhado em Mário Neme, o escritor que fazia parte da equipe e que publicara Notas de Revisão da História de São Paulo (1959) resolvendo a celeuma e falando em obra coletiva, anos depois de Cortesão publicar o seu A Fundação de São Paulo, Capital Geográfica do Brasil. ${ }^{371}$

Apesar de não citá-lo como membro da equipe organizadora, Damante cita o papel de Agostinho da Silva, "braço direito" de Cortesão e seu "genro português" lembrando que sua outra filha fora casada com o poeta Murilo Mendes, relacionamento que teria começado no mesmo Itamaraty em que Cortesão trabalhava. Das relações descritas como "estreitas", Damante destaca, além destas, aquela com o jornalista Júlio de Mesquita Filho - com quem o historiador português compartilharia o "mesmo pendor liberal", pagando ambos "o preço que se paga nas

\footnotetext{
${ }^{370}$ CORTESÃO, J. apud DAMANTE, H. Jaime Cortesão, o historiador de dois povos. In: Comunidades de Lingua Portuguesa, Revista Semestral de Cultura, São Paulo, n. 5, 1985, p. 56.

${ }^{371}$ DAMANTE, H. Op. cit., 1985, p. 57.
} 
lutas pela liberdade". Tal como Ernani Silva Bruno, que havia lembrado o título de "Cidadão paulistano" conferido pelo poder público municipal, Damante destacou no fim de seu texto um título recebido por Cortesão, concedido pela Comissão responsável pelas comemorações centenárias, reconhecendo a sua liderança na monumental exposição de $1954 .{ }^{372}$ Dessa forma, os co-organizadores da mostra comemorativa do centenário paulistano apresentavam o reconhecimento oficial do historiador português, a despeito das eventuais críticas que havia recebido.

Jaime Cortesão esteve mais próximo das instâncias do Poder - seja ele federal, no âmbito do Itamaraty ou da Biblioteca Nacional, seja ele municipal ou estadual, no âmbito das comemorações oficiais do quarto centenário da fundação da cidade de São Paulo - do que de outras dinâmicas do universo intelectual brasileiro. Por esse motivo, igualmente, o reconhecimento oficial de Cortesão, como pudemos acompanhar, acabou sendo, em seu tempo, a principal demonstração de consideração sobre a sua atuação, que se via mais timidamente entre os historiadores locais e o mundo universitário que se constituía. Conforme Nanci Leonzo disse, somente cerca de trinta anos depois de sua morte, a Universidade de São Paulo, "que o marginalizara", escolheu Cortesão para patrono de uma cátedra "destinada a funcionar como um centro coordenador e difusor de estudos luso-afro-brasileiros". ${ }^{373}$

Permanecendo como referência nas áreas de cartografia histórica e mesmo da história das bandeiras, Cortesão chama a atenção por conta de sua produção, que apesar de inovadora em muitos aspectos, sobretudo em termos de fontes e métodos, deu continuidade - ainda que em outras bases - a concepções já consagradas de um pensamento mitologizado a respeito de fenômenos como as bandeiras ou a mestiçagem no contexto da colonização portuguesa. Essa complexidade de sua produção também se destaca quando olhamos para as suas aproximações e distanciamentos com regimes autoritários, trazendo à tona as ambivalências que não raro podemos perceber em intelectuais e escritores das mais diversas áreas. A partir de como bem avaliou Edward Said (2011), não podemos perder de vista pensamentos mais ou menos hegemônicos, que acabam por ser a fonte da qual bebem sujeitos aparentemente em campos totalmente opostos. Nesse sentido, recusando a simplificações, levamos em conta toda a base sobre a qual se assenta o trabalho

\footnotetext{
372 DAMANTE, H. Op. cit., 1985, p. 58-59.

${ }^{373}$ LEONZO, N. Op. cit., 1997, p. 43.
} 
intelectual, na qual atuam forças diversas que vão desde a necessidade de obter recursos financeiros até às concepções políticas, sociais, culturais.

Analisando o perfil intelectual de Cortesão, pudemos notar a mobilização conjunta da arte, da cultura, da ação política e da história/geografia em torno de perspectivas que visavam ao restabelecimento de uma autoestima da nação portuguesa, que encontrou no Brasil o seu espaço privilegiado de reencontro com um passado áureo e que deveria figurar com destaque e reagir às supostas ameaças que sofria. A partir do trabalho de curadoria da Exposição de História de São Paulo no quadro da história do Brasil, o intelectual pôde desfrutar de um espaço privilegiadíssimo - e de uma linguagem bastante eficaz, trabalhando com história e imagem - para apresentar os tons da ação portuguesa que teriam construído o Brasil, tanto como povo quanto como espaço geográfico delimitado. A seu modo, e com fortes tons mitográficos, Cortesão construiu uma interpretação do Brasil que dialogou intensamente com as principais elaborações produzidas até então, tornando-se, inclusive, museólogo.

Evento significativo de sua época, as comemorações do quarto centenário de São Paulo fizeram convergir diversos anseios: o de marcar positivamente a história da colonização portuguesa por meio do bem-sucedido exemplo brasileiro - anseio esse compartilhado por portugueses no Brasil e em Portugal, opositores e apoiadores do salazarismo; o de setores da sociedade paulistana/paulista de firmar a imagem de uma capital cultural do Brasil, por meio de investimentos públicos e privados em diversas iniciativas nesse campo; o de governos federais, especialmente Vargas, tanto ditador quanto presidente eleito, além do que viria a ser posteriormente o governo de Juscelino Kubistchek, no que diz respeito à integração nacional e a ideais de modernização do país. Jaime Cortesão, que trabalhou muito de perto com esses anseios, pode ser visto como um intelectual tanto produtor quanto mediador, que aos projetos locais e portugueses - estes que em parte também eram os do salazarismo, como vimos - articulou não apenas os seus próprios programas e visões de mundo como também se utilizou de meios bastante relevantes, em termos de linguagem e de apelo à sensibilidade, para apresenta-los.

Nesse aspecto, podemos compreender a amplitude do papel que a arte e a arquitetura modernistas desempenharam na construção de um Brasil moderno, representando ao menos na estética um país que buscava se reinventar a partir da 
identificação e valorização de suas matrizes internas e da superação de certos paradigmas estrangeiros. A arquitetura moderna, que antes já havia edificado o prédio do Ministério da Educação dos tempos de Capanema - o que encerra uma simbologia bastante interessante, visto que aquele espaço era um centro fundador e ratificador de ideais educacionais, artísticos, culturais - bem como o conjunto da Pampulha em Belo Horizonte e o Parque Ibirapuera em São Paulo, foi, ainda, a base sobre a qual se construiu a nova capital do Brasil.

$\mathrm{O}$ antigo projeto, que tinha ganhado novo impulso com os planos de Vargas e alcançado concretização no programa de Juscelino Kubitschek, edificou no Planalto Central, local do encontro das bacias do Tocantins, do São Francisco e do Prata, o grande marco do Brasil moderno: Brasília. ${ }^{374}$ Envolto por outros simbolismos, o local da nova capital foi o palco de uma celebração religiosa em 3 de maio de 1957, data em alusão à primeira missa no Brasil. Dessa forma, marcava-se o "redescobrimento da nação, o encontro com seu centro gravitacional" de acordo com o pensamento de Juscelino. No olhar do Presidente da República, a concentração humana que concorria para o evento oferecia um grande "contraste", figurando de um lado "Carajás de penas" e de outro "as elegantes da sociedade carioca" e a moda parisiense, ambos envoltos pela mesma poeira vermelha, que os colocaria em pé de igualdade. O fluxo de trabalhadores - os desbravadores - se organizava na cidade "provisória" que depois veio a se chamar "Núcleo Bandeirante". Novas rodovias e aeroportos abriam os novos caminhos à "integração nacional". ${ }^{375}$ Completando o processo dos tempos de Vargas, Juscelino erigia o monumento que coroava a fusão entre o "tradicional" sertão e a modernidade. E os bandeirantes continuaram, de alguma forma, se fazendo presentes.

Cinquenta anos depois de 1954, quando São Paulo comemorava grandiosamente os seus 450 anos, inaugurava-se em um dos pavilhões do Ibirapuera - o antigo Pavilhão das Nações, outrora destinado a receber grandiosas atividades artísticas e culturais estrangeiras e aberto pela segunda Bienal Internacional de São Paulo, que recebeu a Guernica de Picasso - um novo espaço museológico: o Museu Afro Brasil. Dirigido e composto em grande parte pelo acervo pessoal do artista

\footnotetext{
${ }^{374}$ Lembro aqui dos trabalhos que Jaime Cortesão também participou, enquanto trabalhava na esfera da administração federal, a respeito da geopolítica do Planalto Central.

${ }^{375}$ Kim, L.; Wesely, M. Arquivo Brasília. Textos de Stenzel, E.; Dorfman, G. São Paulo: Cosac Naify, 2010.
} 
plástico Emanoel Araújo, o espaço ora permite que "diversas nações negras, brancas e indígenas exprimam a verdadeira face mestiça desta diversa e única nação à qual chamamos Brasil, formada por efeito de muitas lutas e resistências". Segundo o curador do museu que ocupa os onze mil metros quadrados do atual Pavilhão Padre Manuel da Nóbrega, o antigo prédio de Niemeyer "retoma sua vocação original invocando todas as forças plantadas nesses breves, mas intensos 500 anos de história". ${ }^{376}$ A museologia e a produção do conhecimento histórico, postos em relação, podem ser, da mesma forma como foram em 1954, um instrumento profícuo à mobilização de saberes e transformação de sentidos e representações. O caminho para a emersão de novas narrativas históricas encontra-se aberto.

\section{FONTES}

1. Obras de Jaime Cortesão 377

ÁGuAs, Neves. Bibliografia de Jaime Cortesão: edição comemorativa do $1^{\circ}$ centenário de nascimento de Jaime Cortesão. Lisboa: Biblioteca Nacional, 1985.

CORTESÃO, Jaime. 13 cartas do cativeiro e do exílio (1940). Recolha, introdução e notas de Alberto Pedroso. Lisboa: Biblioteca Nacional, 1987.

A Carta de Pero Vaz de Caminha. Rio de Janeiro: Livros de Portugal, 1943. (Coleção Clássicos e Contemporâneos, v. 1).

. A Fundação de São Paulo: capital geográfica do Brasil. Rio de Janeiro: Livros de Portugal, 1955.

Alexandre de Gusmão e o Tratado de Madrid (1750). Ed. fac-similar. São Paulo: Imprensa Oficial/ Brasília: FUNAG, 2006.

Antecedentes do Tratado de Madri: Jesuitas e Bandeirantes no Paraguai (1703-1751). Introdução, notas e sumário por Jaime Cortesão. Rio de Janeiro: Biblioteca Nacional - Divisão de Obras Raras e Publicações, 1955b. (Manuscritos da Coleção De Angelis, v. 6).

Do Tratado de Madri à Conquista dos Sete Povos (1750-1802). Introdução, notas e sumário por Jaime Cortesão. Rio de Janeiro: Biblioteca Nacional - Divisão de Publicações e Divulgação, 1969b. (Manuscritos da Coleção De Angelis, v. 7).

História da Expansão Portuguesa. Lisboa: Imprensa Nacional - Casa da Moeda, 1993. (Obras Completas de Jaime Cortesão, v. 4).

\footnotetext{
${ }^{376}$ ARAÚJO, E. Museu Afro Brasil: Um conceito em perspectiva. In: conceito em perspectiva. Catálogo. São Paulo: Instituto Florestan Fernandes, 2006. ${ }^{377}$ Os títulos estão em ordem alfabética. (org.). Museu Afro Brasil: um
} 
História do Brasil nos velhos mapas. Lisboa: Imprensa Nacional/Casa da Moeda, 2009. 2 v. (Obras Completas de Jaime Cortesão, v. 11).

. Introdução à História das Bandeiras. Lisboa: Livros Horizonte, 1975. 2 v.

. Jesuitas e Bandeirantes no Guairá (1594-1640). Introdução, notas e glossário por

Jaime Cortesão. Rio de Janeiro: Biblioteca Nacional/Divisão de Obras Raras e Publicações, 1951. (Manuscritos da Coleção De Angelis, v. 1).

. Jesuitas e Bandeirantes no Itatim (1596-1760). Introdução, notas e glossário por Jaime Cortesão. Rio de Janeiro: Biblioteca Nacional - Divisão de Obras Raras e Publicações, 1952. (Manuscritos da Coleção De Angelis, v. 2).

- Jesuitas e Bandeirantes no Tape (1615-1641). Introdução e notas por Jaime Cortesão. Rio de Janeiro: Biblioteca Nacional - Divisão de Publicações e Divulgação, 1969. (Manuscritos da Coleção De Angelis, v. 3).

- O humanismo universalista dos portugueses: a síntese histórica e literária. Lisboa: Portugália, 1965. (Obras Completas de Jaime Cortesão, v. 6). 1978.

. Os fatores democráticos na formação de Portugal. $3^{\mathrm{a}}$ ed., Lisboa: Livros Horizonte,

. Portugueses e índios no Brasil colonial. São Paulo: ECA-USP, 1972. (Série Cultura Geral, 22).

Raposo Tavares e a formação territorial do Brasil. Rio de Janeiro: Ministério da Educação e Cultura, 1958.

Tratado de Madri: Antecedentes - Colonia do Sacramento (1669-1749). Introdução, notas, sumários por Jaime Cortesão. Rio de Janeiro: Biblioteca Nacional - Divisão de Obras Raras e Publicações, 1954. (Manuscritos da Coleção De Angelis, v. 5).

2. Arquivos

EsPólio Jaime CoRTesÃo. Arquivo de Cultura Portuguesa Contemporânea da Biblioteca Nacional de Portugal.

Coleção iV Centenário da Cidade de SÃo Paulo. Museu Paulista da Universidade de São Paulo.

\section{BIBLIOGRAFIA}

ABUD, Kátia Maria. O sangue intimorato e as nobilíssimas tradições: a construção de um símbolo paulista: o bandeirante. Tese (Doutorado em História), Faculdade de Filosofia Letras e Ciências Humanas, Universidade de São Paulo, São Paulo, 1985. 
ADONIAS. Isa. Jaime Cortesão e seus mapas. Rio de Janeiro: IHGB, 1984.

AlenCAstro, Luiz Felipe de. O trato dos viventes: formação do Brasil no Atlântico Sul. São Paulo: Companhia das Letras, 2000.

AleXANDRE, Valentim. Velho Brasil, novas Áfricas: Portugal e o Império (1808-1975). Porto: Afrontamento, 2000.

AMADO, Janaína. Região, Sertão, Nação. In: Estudos Históricos, Rio de Janeiro, v. 8, n. $15,1995$.

ANDERSON, Benedict. Comunidades imaginadas: reflexões sobre a origem e a difusão do nacionalismo. São Paulo: Companhia das Letras, 2008.

ANHEZINI, Karina. Um metódico à brasileira: a escrita da história de Afonso de Taunay. In: Revista de História, São Paulo, n. 160, jan.-jun. 2009.

BARbuY, Heloisa. A Exposição Universal de 1889 em Paris. São Paulo: Loyola, 1999.

A cidade-exposição: comércio e cosmopolitismo em São Paulo, 1860-1914. São Paulo: Edusp, 2006.

BARONE, Ana Cláudia Castilho. A oposição aos pavilhões do parque Ibirapuera (1950-1954). In: Anais do Museu Paulista, São Paulo, v. 17, n. 2, jul.-dez. 2009.

BOMENY, Helena. Três decretos e um ministério: a propósito da educação no Estado Novo. In: PANDOLFI, Dulce (org.). Repensando o Estado Novo. Rio de Janeiro: Ed. FGV, 1999.

(org.). Constelação Capanema: intelectuais e políticas. Rio de Janeiro: Ed. FGV; Bragança Paulista: Ed. USF, 2001.

Bourdieu, Pierre. Campo intelectual e projeto criador. In: PouILlon, Jean et al. (org.). Problemas do Estruturalismo. Rio de Janeiro: Zahar, 1968.

A ilusão biográfica. In: FERREIRA, Marieta e AMADO, Janaína (org.). Usos e abusos da História Oral. Rio de Janeiro: Ed. FGV, 1996.

BOXER, Charles R. O império marítimo português (1415-1825). São Paulo: Companhia das Letras, 2002.

BRUNO, Ernani Silva. História e Tradições da Cidade de São Paulo. 3 v. Rio de Janeiro: José Olympio, 1953.

O centenário de Jaime Cortesão, luso-paulista. In: Comunidades de Língua Portuguesa, Revista Semestral de Cultura, Ed. esp. Intercâmbio Portugal-Brasil, São Paulo, n. 5, 1985.

CAMARgo, Alexandre de Paiva Rio. A Revista Brasileira de Geografia e a organização do campo geográfico no Brasil (1939-1980). In: Revista Brasileira de História da Ciência, Rio de Janeiro, v. 2, n. 1, p. 23-39, jan.-jun. 2009. 
CASTElo, Claudia. O modo português de estar no mundo: o luso-tropicalismo e a ideologia colonial portuguesa (1933-1961). Porto: Afrontamento, 1998.

Novos Brasis em África: desenvolvimento e colonialismo português tardio.

In: Varia Historia, Belo Horizonte, v. 30, n. 53, mai.-ago. 2014

Certeau, Michel de. A escrita da história. $2^{\text {a }}$ Ed. Rio de Janeiro: Forense Universitária, 1982.

Compagnon, Olivier. L'adieu à l'Europe: l'Amérique Latine et la Grande Guerre. Paris: Fayard, 2013.

CONCEIÇÃo NeTO, Maria da. Ideologias, contradições e mistificações da colonização de Angola no século XX. In: Lusotopie, Bordeaux, 1997.

Damante, Hélio. Jaime Cortesão, o historiador de dois povos. In: Comunidades de Língua Portuguesa, Revista Semestral de Cultura, Ed. esp. Intercâmbio Portugal-Brasil, São Paulo, n. 5, 1985.

Della VAlle, Franco. Vida e morte do bandeirante: Alcântara Machado e a produção da história paulista. Dissertação (Mestrado em História Social), Faculdade de Filosofia, Letras e Ciências Humanas da Universidade de São Paulo, São Paulo, 2015.

DEVAlLON, Jean. Comunicação e sociedade: pensar a concepção da exposição. In: MAGAlHÃEs, Aline Montenegro; BeZERRA, Rafael Zamorano; BENCHETRIT, Sarah (org.). Museus e comunicação: exposições como objeto de estudo. Rio de Janeiro: Museu Histórico Nacional, 2010.

FERREIRA, Antonio Celso. A epopeia bandeirante: letrados, instituições, invenção histórica (1870-1940). São Paulo: Ed. UNESP, 2002.

FoucAult, Michel. O que é um autor? Lisboa: Passagens, 1997.

FREIXO, Adriano de. A língua portuguesa como utopia: Agostinho da Silva e o ideal da comunidade lusófona. In: Revista Convergência Lusíada, Rio de Janeiro, n. 23, 2007.

FREYRE, Gilberto. Casa Grande \& Senzala: formação da família brasileira sob o regime da economia patriarcal. 51ª ed. rev. São Paulo: Global, 2006.

O mundo que o português criou: aspectos das relações sociais e de cultura no Brasil com Portugal e as colônias portuguesas. São Paulo: É Realizações, 2010.

Gomes, Angela Maria de Castro. A política brasileira em busca da modernidade: na fronteira entre o público e o privado. In: SCHWARCZ, Lilia M.; NOVAIS, Fernando (org.) História da Vida Privada no Brasil, v. 4: contrastes da intimidade contemporânea. São Paulo: Companhia das Letras, 1998. FGV, 1999.

História e Historiadores: a politica cultural do Estado Novo. Rio de Janeiro: Ed.

GRIN, Monica. Mitos de excepcionalidade: versões do Império português e da nação miscigenada brasileira. In: CATroga, F., HERmanN, J., AzEVEdo, F. L. N. (org.). 
Memória, escrita da história e cultura política no mundo luso-brasileiro. Rio de Janeiro: Ed. FGV, 2012.

Gross, Neil. Richard Rorty's pragmatism: a case study in Sociology of Ideas. In: Theory and Society, v. 32, 2003.

GUIMARÃEs, Lucia Maria Paschoal. Relações culturais luso-brasileiras: alguns pontos de confluência. In: Revista Convergência Lusíada, Rio de Janeiro, n. 24, 2007.

GuIMARÃEs, Manoel Luís Salgado. Nação e civilização nos trópicos: o Instituto Histórico e Geográfico Brasileiro e o projeto de uma História Nacional. In: Estudos Históricos, Rio de Janeiro, n. 1, 1988.

- História e Natureza em von Martius: esquadrinhar o Brasil para produzir a nação. In: História, Ciências, Saúde - Manguinhos, Rio de Janeiro, v. 7, n. 2, out. 2000.

Expondo a História: imagens construindo o passado. In: Anais do Museu Histórico Nacional, Rio de Janeiro, v. 34, p. 71-86, 2002.

. Vendo o passado: representação e escrita da história. In: Anais do Museu Paulista, São Paulo, v. 15, n. 2, jul.-dez. 2007.

HoBSBAWM, Eric J. Era dos Extremos: o breve século XX (1914-1991). 2a ed. São Paulo: Companhia das Letras, 1995.

HocH, Paul. Migration and Generation of New Scientific Ideas. In: Minerva, v. 25, n. 3, 1987.

HolandA, Sérgio Buarque de. Raízes do Brasil. 26 ed. São Paulo: Companhia das Letras, 1995.

Caminhos e Fronteiras. $3^{\text {a }}$ Ed. São Paulo: Companhia das Letras, 1994.

Visão do Paraíso: os motivos edênicos no descobrimento e colonização do Brasil.

São Paulo: Companhia das Letras, 2010.

Monções. Org. Laura de Mello e Souza e André Sekkel Cerqueira. $4^{\mathrm{a}}$ ed. São Paulo: Companhia das Letras, 2014.

Capitulos de Expansão Paulista. Org. Laura de Mello e Souza e André Sekkel Cerqueira. São Paulo: Companhia das Letras, 2014.

JEANPIERRE, Laurent. Une opposition structurante pour l'anthropologie structurale : Lévi-Strauss contre Gurvitch, la guerre de deux exilés français aux États-Unis. In : Revue d'Histoire des Sciences Humaines, Paris, n. 11, jul.-dez. 2004.

KANTOR, Íris. Usos diplomáticos da ilha-Brasil: polêmicas cartográficas e historiográficas. In: Varia Historia, Belo Horizonte, vol. 23, n. 37, jan.-jun. 2007.

Cartografia e diplomacia: usos geopolíticos da informação toponímica (1750-1850). In: Anais do Museu Paulista, São Paulo, n. sér. vol. 17, n. 2, jul.-dez. 2009. 
KoK, Glória. O sertão itinerante: as expedições da capitania de São Paulo no século XVIII. São Paulo: Ed. Hucitec/FAPESP, 2004.

Lemos, Fernando; LeITE, Rui Moreira (org.). A Missão Portuguesa: rotas entrecruzadas. São Paulo: Ed. UNESP; Bauru: EDUSC, 2003.

LEONZO, Nanci. O “mistério” das Bandeiras. In: Prelo, Lisboa, n. esp., dez. 1984. Jaime Cortesão: um condestável em terras brasileiras. In: Revista da Cátedra Jaime Cortesão, São Paulo, v. 1, n. 1, 1997.

Lofego, Silvio Luiz. IV Centenário da Cidade de São Paulo: uma cidade entre o passado e o futuro. São Paulo: Annablume, 2004.

LoRCA, German. A São Paulo de German Lorca. Texto de José de Souza Martins. São Paulo: Imprensa Oficial do Estado de São Paulo/Secretaria Municipal de Cultura, 2013.

MACAGNO, Lorenzo. Luso-tropicalismo e nostalgia etnográfica: Jorge Dias entre Portugal e Moçambique. In: Afro-Ásia, Salvador, n. 28, 2002.

MACEDO, Jorge Borges de. A teoria da História de Jaime Cortesão. In: Prelo, Lisboa, n. esp., dez. 1984.

MARGARIDO, Alfredo. A lusofonia e os lusófonos: novos mitos portugueses. Lisboa: Edições Universitárias Lusófonas, 2000.

MARINS, Paulo César Garcez. O Parque do Ibirapuera e a construção da identidade paulista. In: Anais do Museu Paulista, São Paulo, nova série, vol. 6/7, 1998/1999.

MARTIUS, Karl Friedrich von. Como se deve escrever a história do Brasil. $3^{\mathrm{a}}$ ed. Rio de Janeiro: Instituto Histórico e Geográfico Brasileiro, 1991. (Coleção Capistrano de Abreu, v. 1).

MAtos, Patrícia Ferraz de. As "Côres" do Império: representações raciais no Império Colonial Português. Lisboa: Imprensa de Ciências Sociais, 2006.

MEDINA, João. Gilberto Freyre contestado: o luso-tropicalismo criticado nas colônias portuguesas como álibi colonial do salazarismo. In: Revista USP. São Paulo, n. 45, mar.-mai., 2000.

Meneses, Ulpiano T. Bezerra de. Do teatro da memória ao laboratório da História: a exposição museológica e o conhecimento histórico. In: Anais do Museu Paulista. São Paulo, n. sér., v. 2, jan.- dez. 1994.

MiCELI, Sergio. Intelectuais à brasileira. São Paulo: Companhia das Letras, 2001.

MonteIRO, John Manuel. Negros da terra: índios e bandeirantes nas origens de São Paulo. São Paulo: Companhia das Letras, 1994. 
Tupis, Tapuias e historiadores: estudos de história indígena e do indigenismo. Tese (Livre-docência), Instituto de Filosofia e Ciências Humanas, Universidade Estadual de Campinas, Campinas, 2001.

NEVES, João Alves das. A colaboração de Jaime Cortesão na imprensa brasileira. In: Comunidades de Língua Portuguesa, Revista Semestral de Cultura, Ed. esp., São Paulo, n. $5,1985$.

OliveIRA, Daíse; BARros, Leliane; Yoshimoto, Celina. No IV centenário da cidade de São Paulo. In: Prelo, Lisboa, n. esp., dez. 1984.

OliveIRA, Francisco Roque de. História da Cartografia Brasileira e Mapoteconomia segundo Jaime Cortesão: o curso do Itamaraty de 1944. In: Anais do IV Simpósio Iberoamericano de História da Cartografia, São Paulo, 2010.

OliveIRA, Lúcia; Velloso, Mônica; Gomes, Ângela (org.) Estado Novo: ideologia e poder. Rio de Janeiro: Zahar, 1982.

OlIVEIRA, Lúcia Lippi. A conquista do espaço: sertão e fronteira no pensamento brasileiro. In: História, Ciências, Saúde - Manguinhos, Rio de Janeiro, v. 5 (supl.), jul. 1998.

OliveIRA JúnIOR, Gilson Brandão de. Agostinho da Silva e o Centro de Estudos Afroorientais (CEAO): a primeira experiência institucional dos estudos africanos no Brasil. Dissertação (Mestrado em História Social), Faculdade de Filosofia, Letras e Ciências Humanas, Universidade de São Paulo, São Paulo, 2010.

PALMEIRA, Miguel Soares. Moses Finley e a "economia antiga": a produção social de uma inovação historiográfica. Tese (Doutorado em História Social). Faculdade de Filosofia, Letras e Ciências Humanas, Universidade de São Paulo, São Paulo, 2007.

Peixoto, Fernanda Arêas. Bastide e Verger entre "áfricas" e "brasis": rotas entrelaçadas, imagens superpostas. In: Revista IEB, São Paulo, n. 50, set./mar. 2010.

PIMENTEL, João Sarmento. Portugueses emigrados políticos no Brasil. In: Seara Nova, Lisboa, número de homenagem a Jaime Cortesão, n. 1266-69, 27 dez. 1952.

PINHO, Amon. A diáspora da inteligência lusa na hermenêutica histórica de Agostinho da Silva: uma teoria antielitista da História de Portugal?. In: Revista Convergência Lusíada, Rio de Janeiro, n. 23, 2007.

PONTES, Heloisa Andrade. Destinos mistos: os críticos do grupo Clima em São Paulo (19401968). São Paulo: Companhia das Letras, 1998.

Poulot, Dominique. Musée et muséologie. Paris: La Découverte, 2009. (Collection Repères).

REIS, José Carlos. As Identidades do Brasil: de Varnhagen a FHC. $9^{\mathrm{a}}$ ed. rev. e ampl. Rio de Janeiro: Ed. FGV, 2007.

RÉMOND, René. Uma história presente In: (org.). Por uma História Política. $2^{\mathrm{a}}$ ed. Rio de Janeiro: Ed. FGV, 2003. 
RIBEIRO, Aquilino. Reencontro com Jaime Cortesão. In: Seara Nova, Lisboa, número de homenagem a Jaime Cortesão, n. 1266-69, 27 dez. 1952.

RIBEIRO, Darcy. O povo brasileiro: a formação e o sentido do Brasil. São Paulo: Companhia das Letras, 2006.

RODRIGUES, Lidiane Soares. A produção social do marxismo universitário em São Paulo: mestres, discípulos e "um seminário" (1958-1978). Tese (Doutorado em História Social), Faculdade de Filosofia, Letras e Ciências Humanas, Universidade de São Paulo, São Paulo, 2011.

SAID, Edward W. Orientalismo: o Oriente como invenção do Ocidente. São Paulo: Companhia das Letras, 2007.

. Cultura e Imperialismo. São Paulo: Companhia das Letras, 2011.

SAntos, Alfredo Ribeiro dos. Jaime Cortesão: um dos grandes de Portugal. Porto: Fundação Engenheiro Antonio de Almeida, 1993.

SCHMIDT, B. B. Construindo biografias... Historiadores e jornalistas: aproximações e afastamentos. In: Estudos Históricos, Rio de Janeiro, n. 19, 1997.

SCHWARCZ, Lilia Moritz. O espetáculo das raças: cientistas, instituições e questão racial no Brasil, 1870-1930. São Paulo: Companhia das Letras, 1993.

SECCO, Lincoln. A Revolução dos Cravos. São Paulo: Alameda, 2004.

SERRÃO, Joel. Relance sobre a vida e a obra historiográfica de Jaime Cortesão. In: Prelo, Lisboa, n. esp., dez. 1984; In: Comunidades de Lingua Portuguesa, Revista Semestral de Cultura, Ed. esp. Intercâmbio Portugal-Brasil: Jaime Cortesão e o Brasil, São Paulo, n. 5, 1985.

SEVCEnKo, Nicolau. Orfeu extático na metrópole: São Paulo, sociedade e cultura nos frementes anos 20. São Paulo: Companhia das Letras, 1992.

Silva, Maria Beatriz Nizza da. Cortesão no Instituto Rio Branco. In: Prelo, Lisboa, n. esp., dez. 1984.

Cartas de Jaime Cortesão na Biblioteca Nacional do Rio de Janeiro. Comunidades de Língua Portuguesa, Revista Semestral de Cultura, Ed. esp. Intercâmbio Portugal-Brasil: Jaime Cortesão e o Brasil, São Paulo, n. 5, 1985.

SILVA, Tathianni Christinni da. Um intelectual caipira na cidade: a trajetória de Mário Neme e sua gestão no Museu Paulista. Tese (Doutorado em História Social). São Paulo, Universidade de São Paulo, 2014.

SIRINELLI, Jean-François. Os intelectuais In: RÉMOND, René. (org.). Por uma História Política. 2a ed. Rio de Janeiro: Ed. FGV, 2003.

Thomaz, Omar Ribeiro. Ecos do Atlântico Sul: representações sobre o terceiro império português. Rio de Janeiro: Ed. UFRJ/FAPESP, 2002. 
VAsConCELlos, Camilo de Mello. Imagens da Revolução Mexicana: o Museu Nacional de História do México (1940-1982). São Paulo: Alameda, 2007.

Velloso, Mônica Pimenta. A brasilidade verde-amarela: nacionalismo e regionalismo paulista. In: Estudos Históricos. Rio de Janeiro, vol. 6, n. 11, 1993.

Os intelectuais e a política cultural do Estado Novo In: FERREIRA, Jorge; DELGADO, Lucília Neves (org.) O Brasil Republicano, v. 2: o tempo do nacional-estatismo do início da década de 1930 ao apogeu do Estado Novo. Rio de Janeiro: Civilização Brasileira, 2003.

WiSSENBACH, Maria Cristina Cortez Desbravamento e catequese na construção da nacionalidade brasileira: as expedições do Barão de Antonina no Brasil meridional. In: Revista Brasileira de História, São Paulo, v. 15, n. 30, 1995.

Ares e azares da aventura ultramarina: matéria médica, saberes endógenos e transmissão no circuito Atlântico luso-afro-americano In: ALGRANTI, Leila Mezan e Megiani, Ana Paula Torres. O Império por escrito: formas de transmissão da cultura letrada no mundo ibérico, séculos XVI-XIX. São Paulo: Alameda, 2009. 